ROBERTO AGUIAR DOS SANTOS

COMPORTAMENTO ANISOTRÓPICO DE UM SOLO LATERÍTICO COMPACTADO 

ROBERTO AGUIAR DOS SANTOS

\title{
COMPORTAMENTO ANISOTRÓPICO DE UM SOLO LATERÍTICO COMPACTADO
}

\begin{abstract}
Dissertação apresentada à Escola de Engenharia de São Carlos da Universidade de São Paulo como parte dos requisitos para obtenção do Título de Mestre em Ciências, Programa de Pós-graduação em Geotecnia.
\end{abstract}

Versão corrigida - Original se encontra disponível na Unidade que aloja o Programa

Orientador: Prof. Dr. Edmundo Rogerio Esquivel 
AUTORIZO A REPRODUÇÃO TOTAL OU PARCIAL DESTE TRABALHO, POR QUALQUER MEIO CONVENCIONAL OU ELETRÔNICO, PARA FINS DE ESTUDO E PESQUISA, DESDE QUE CITADA A FONTE.

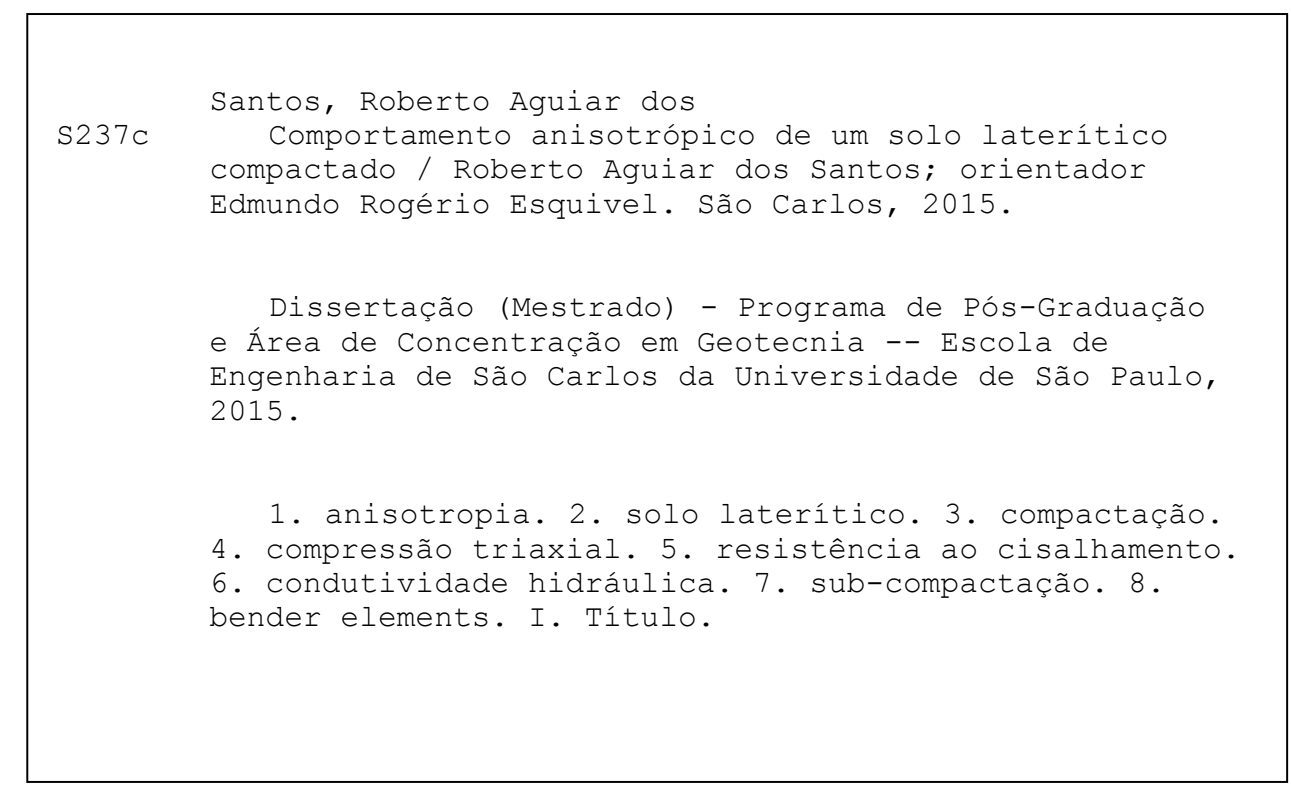




\section{FOLHA DE JULGAMENTO}

Candidato: Bacharel ROBERTO AGUIAR DOS SANTOS.

Título da dissertação: "Comportamento anisotrópico de um solo laterítico compactado".

Data da defesa: 04/12/2015

Comissão Julgadora:

Prof. Dr. Edmundo Rogério Esquivel

(Orientador)

(Escola de Engenharia de São Carlos/EESC)

Prof. Titular Orencio Monje Vilar

(Escola de Engenharia de São Carlos/EESC)
Resultado:

Mrovana

Prof. Dr. Roger Augusto Rodrigues

APRQVADO

(Universidade Estadual Paulista "Julio de Mesquita Filho"/UNESP - Bauru)

Coordenador do Programa de Pós-Graduação em Geotecnia:

Prof. Dr. Edmundo Rogério Esquivel

Presidente da Comissão de Pós-Graduação:

Prof. Associado Paulo César Lima Segantine 

À minha família, pelo seu constante apoio e incentivo ao longo da minha trajetória de tensões. 



\section{AGRADECIMENTOS}

À Deus. Por se mostrar presente em diversas etapas da minha vida.

Aos meus pais e irmãos. Ao meu pai, Sr. José Roberto, que tenho como referência de vida e por promover os estímulos iniciais no campo da geotecnia. A minha mãe, Sra. Teresa, pelo carinho e pela extrema dedicação familiar empregada ao logo da minha existência. Muito obrigado!

Ao meu orientador, Prof. Edmundo Rogério Esquivel pela orientação, amizade, sugestões e críticas. Muito obrigado!

Ao Prof. Orencio Monje Vilar pela orientação, amizade e por compartilhar suas valiosas sugestões, ensinamentos e críticas. Por sempre se fazer presente ao longo desta pesquisa. Muito obrigado!

Ao Prof. Lázaro Valentin Zuquette pelas discussões ao longo desta pesquisa, e pela sua sugestão relacionada a aspersão de azul de metileno entre as camadas compactadas.

Ao Sr. Antônio Garcia, ao Sr. Luiz Guerra, e ao amigo Oscar dos Santos pelas ajudas laboratoriais sempre que solicitadas. Aos demais funcionários do Departamento de Geotecnia pelo irrestrito apoio nos assuntos do dia a dia.

À Tálita por todo incentivo e carinho ao longo desta pesquisa, mostrando-se sempre solidária nos momentos de maior dificuldade. Por sempre ouvir minhas ideias e questionamentos. Por todas as revisões textuais. Muito obrigado!

Aos amigos Breno Rocha, Christopher Fonseca e João Parizotto pela companhia, ideias, e pelos estímulos nos dias e noites de ensaios e estudos afincos dentro do Departamento de Geotecnia. Por todas as revisões textuais. Muito obrigado!

As amigas: Ana Elisa Abreu e Giovana Georgetti pelas valiosas opiniões, questionamentos e sugestões. Pelas discussões técnicas. Muito obrigado!

Aos demais colegas e amigos da pós-graduação em geotecnia, em especial: Mariana Fernandes, João Manoel, Thaíse Morais, Gian Franco, Vanessa Almeida, Jussara Mechetti, Denis Watashi, Camila Eberle, Katerin Guerrero. Meu muito obrigado!

À Universidade de São Paulo e ao Departamento de Geotecnia.

À CAPES pela bolsa de estudos concedida. 



\section{RESUMO}

SANTOS, R.A. (2015). Comportamento anisotrópico de um solo laterítico compactado, São Carlos, 153p. Dissertação (Mestrado em Geotecnia), Escola de Engenharia de São Carlos, Universidade de São Paulo.

A compactação de aterros pode gerar comportamento anisotrópico, a depender do teor de umidade de compactação, entre outros fatores. O principal objetivo deste estudo foi investigar alguns aspectos relacionados à anisotropia inerente induzida pela compactação de um solo laterítico. Após realizar a caracterização mineralógica, geotécnica e microestrututral deste solo, estudou-se a resistência ao cisalhamento, condutividade hidráulica, compressibilidade e deformabilidade. O solo estudado foi classificado como laterítico arenoso (LA') e apresentou agregação relativa da ordem de $12 \%$. A metodologia desenvolvida no intuito de corrigir o aumento na massa específica seca das camadas inferiores, causado pelo processo de compactação, mostrou-se eficaz. A partir da curva de compactação foram consideradas amostras representativas das três condições de umidade de compactação: ramo seco, umidade ótima e ramo úmido. Corpos de prova foram talhados paralelamente e ortogonalmente às camadas de compactação. Os ensaios de porosimetria revelaram um comportamento bimodal na distribuição do tamanho de poros e também que o teor de umidade de compactação não interferiu no tamanho dos microporos. Para o solo compactado no ramo seco e na umidade ótima, a resistência ao cisalhamento correspondente à direção ortogonal se mostrou superior àquela correspondente à direção paralela às camadas de compactação. Por outro lado, a resistência ao cisalhamento no ramo úmido mostrou-se praticamente independente da direção de talhagem dos corpos de prova. Este comportamento se deve à maior capacidade do solo, em um dado teor de umidade, em absorver a energia aplicada e distribuí-la na direção paralela e ortogonal. Com relação às propriedades elásticas do material, observou-se que o aumento do teor de umidade de compactação contribui para redução da anisotropia de deformabilidade. Dentre as propriedades investigadas, a anisotropia de condutividade hidráulica das amostras correspondente ao ramo úmido foi a mais pronunciada, exibindo fluxo oito vezes maior na direção vertical que na horizontal. Finalmente, as discussões e análises apresentadas nesta pesquisa mostraram que o grau de anisotropia depende diretamente do teor de umidade de compactação e que diminui com incremento das tensões aplicadas no solo.

Palavras-chave: Anisotropia, solo laterítico, compactação, compressão triaxial, resistência ao cisalhamento, condutividade hidráulica, sub-compactação, bender elements. 

SANTOS, R.A. (2015). Anisotropic behavior of a compacted laterite soil, São Carlos, 153p. Dissertação (Mestrado em Geotecnia), Escola de Engenharia de São Carlos, Universidade de São Paulo.

Compacted embankments can have anisotropic behavior, depending on several factors, including the compaction water content. The aim of this study was to investigate some aspects regarding the inherent anisotropy of a lateritic soil, caused by the compaction process. After performing the geotechnical, mineralogical and microstructural characterization, properties of shear strength, hydraulic conductivity, compressibility and deformability were investigated. This soil this soil was classified as lateritic sand. The grainsize distribution curve indicates $12 \%$ the fine particle aggregation. The methodology developed in order to correct the increase in dry density of the lower layers, generated by the compression process, was effective. From the compaction curve, representative samples corresponding to the three compaction water content conditions, representing the dry side, the optimal water content and the wet side were considered. Specimens were trimmed parallel and orthogonally to the compaction layers. The porosimetry tests showed a bimodal behavior in the pore size distribution and also that the compaction water content did not influence the size of the micropores. For the compacted soil sample corresponding to the dry side and optimum water content, the shear strength corresponding to the orthogonal direction was higher than that corresponding to the parallel direction to the compaction layers. However, they were almost equal for both the orthogonal and the parallel directions to the compaction layers. This behavior is due to the higher capacity of the soil at a given moisture content, to absorb the energy applied and distribute it in parallel and orthogonal direction. The analysis the values of maximum shear modulus of the material showed that increasing compaction water content reduces the anisotropy degree. Among the investigated properties, the hydraulic conductivity anisotropy of the samples corresponding to the wet branch was the most pronounced, showing permeability eight times higher in the vertical direction than that in the horizontal direction. Finally, the discussions and analyzes presented in this study showed that the degree of anisotropy directly depends on the compaction water content and decreases with increase confining stress applied to the soil specimens.

Keywords: anisotropy, lateritic soil, compaction, triaxial compression, shear strength, hydraulic conductivity, undercompaction, bender elements. 



\section{LISTA DE FIGURAS}

Figura 1 - Estrutura de amostras indeformadas de solos tropicais: a) fortemente intemperizado; b) pouco intemperizado. (CAMAPUM DE CARVALHO et al., 2012). 29

Figura 2 - Curva de compactação.

Figura 3 - Estrutura do solo compactado: (a) Interagregados (macroporos), e (b), Intraagregados (microporos). (BORGES, 2014)...

Figura 4 - Distintos arranjos de partículas com o mesmo índice de vazios e mesma densidade (Adaptada de JUANG; HOLTZ, 1986).

Figura 5 - Influência do tipo de compactação na estrutura dos solos compactados (Adaptada de MARANHA DAS NEVES, 1971).

Figura 6 - Distribuição de volume de poros em função do diâmetro (Adaptada de DELAGE et al., 1996).....

Figura 7 - Imagens de microscopia eletrônica de varredura obtidas de corpos de prova moldados na curva de compactação (x4000). (OLIVEIRA, 2004).

Figura 8 - Perfil típico de barragens brasileiras (Adaptada de CRUZ, 1999).

Figura 9 - Envoltória de resistência para solos compactados (Adaptada de MELLO, 1977). 43

Figura 10 - Trajetória de tensões totais e efetivas para diferentes condições de préadensamento. (Adaptada de BREAUD, 2013).

Figura 11 - Tendência de intercepto coesivo efetivo em termos de tensões efetivas para ensaios do tipo CU. (PINTO, 1971; 2006).

Figura 12 - Comportamento não linear da deformabilidade (a) tensão-deformação e (b) módulo de deformabilidade (Adaptada de ATKINSON, 2000).

Figura 13 - Esquema de propagação de onda cisalhante no corpo de prova (Adaptada de BRIAUD, 2013)

Figura 14 - $G_{0}$, sucção matricial e peso específico seco para os corpos de prova compactados em diferentes teores de umidade para a mesma energia (HEITOR; INDRARATNA; RUJIKIATKAMJORN, 2013).

Figura 15 - Variação da condutividade hidráulica em solos compactados com diferentes energias. (Adaptada de MITCHELL; HOOPER; CAMPANELLA, 1965).

Figura 16 - Efeito do ensaio de compressão confinada na estrutura: (a) baixas tensões aplicada; (b) altas tensões aplicadas (Adaptada de LAMBE, 1958).

Figura 17 - Tendência de variação da compressibilidade (PINTO, 2006)............................54

Figura 18 - Direção da anisotropia de resistência (ABRAMSON, 2002).

Figura 19 - Trajetória de tensões totais e efetivas em ensaio triaxial para corpos de prova orientados em diferentes direções (Adaptada de MITCHELL; SOGA, 2005).

Figura 20 - Comportamento típico de solo compactado e talhados na direção vertical e horizontal (Adaptada de KONGSUKPRASERT; SANO; TATSUOKA, 2007)

Figura 21 - Anisotropia de resistência não drenada em condições saturadas e não saturadas: (a) influência da umidade; (b) influência da massa específica seca e (c) influência da condição de saturação das amostras compactadas com $\rho_{d}=1,56 \mathrm{~g} / \mathrm{cm}^{3}$.

(ROWSHANZAMIR; ASKARI, 2010). 
Figura 22 - Parâmetros de resistência obtidos em ensaios do tipo CD em diferentes inclinações de moldagem para condição saturada e não saturada. (HAM et al., 2012)..... 60

Figura 23 - Influência da sucção matricial na anisotropia de deformabilidade (Adaptada de NG; YUNG, 2008).

Figura 24 - Efeito da direção do fluxo na condutividade hidráulica de uma argila compactada (Adaptada de BOYNTON; DANIEL, 1985). 62

Figura 25 - Influência da tensão de confinamento: (a) na condutividade hidrálica orientadas frente ao plano de compactação; (b) na anisotropia (Adaptada de SHAFIEE, 2008), ..........64

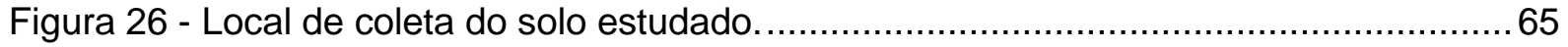

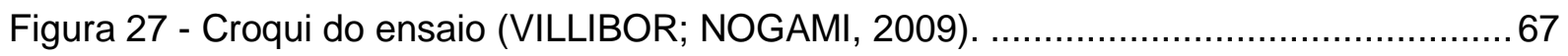

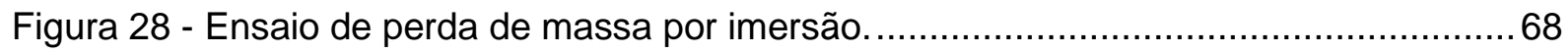

Figura 29 - Fluxograma Mini-MCV e ensaio associado da perda de massa (VILLIBOR;

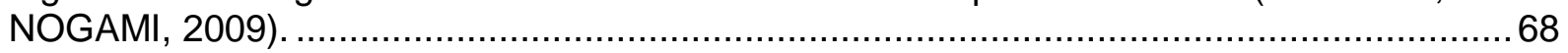

Figura 30 - Princípo de lei de Bragg (Adaptada de MUKHERJEE, 2013)...........................71

Figura 31 - Preparo das lâminas de DRX: (a) em fase de decantação; (b) em fase de secagem ao ar.

Figura 32 - Compactação das amostras: (a) equipamento utilizado; (b) execução da compactação; (c) escarificação; (d) aspersão do azul de metileno; (e) extração da amostra.

Figura 33 - Ensaio de massa específica do solo pelo método da imersão: (a) equipamentos utilizados; (b) corte longitudinal; (c) corte transversal; (d) disposição e esquema de identificação dos corpos de prova; (e) talhamento dos corpos de prova; (f) imersão em parafina.

Figura 34 - Sentido da retirada dos corpos de prova cilíndricos logo após a compactação. . 78

Figura 35 - Corpos de prova cilíndricos: (a) Processo de moldagem dos corpos de prova cilíndricos; (b) após a moldagem na direção horizontal.

Figura 36 - Sentidos de amostragem nos dois sentidos dos corpos de prova utilizados no ensaio de compressão confinada.

Figura 37 - Moldagem dos corpos de prova para o ensaio de compressão confinada: a) moldagem na direção. horizontal; b) cravação do anel de adensamento na direção vertical.

Figura 38 - Corpo de prova moldado para realização do ensaio de porosimetria por intrusão de mercúrio.

Figura 39 - Ensaio oedométrico: a) posicionamento do corpo de prova na prensa; b) vista dos 3 ensaios em andamento e posicionamento de acesso a bureta na parte inferior ao corpo de prova.

Figura 40 - Esquema para saturação dos corpos de prova............................................ 83

Figura 41 - Equipamentos para ensaios de compressão triaxial. .86

Figura 42 - Preparação das amostras para ensaio com bender elements: (a) armazenamento dos corpos de prova talhados; (b) simetria para execução das ranhuras; (c) ranhura.

Figura 43 - Corpo de prova instalado e acompanhado de sobrecarga.

Figura 44 - Determinação do tempo de viagem da onda (GEORGETTI, 2014)....................89

Figura 45 - Análises granulométricas do solo. 
Figura 46 - Curva de compactação.

Figura 47 - Curvas de diferença de altura em função do número de golpes (determinação de $\left.c^{\prime}\right)$......

Figura 48 - Curva de compactação com o número de golpes para cada teor de umidade ensaiado (determinação $d$ ).

Figura 49 - Curva de perda de massa por imersão em função do Mini-MCV (Determinação do PI).

Figura 50 - Posição do solo no gráfico da classificação da MCT. .95

Figura 51 - Difratograma de raio-X para a lâmina normal. 97

Figura 52 - Difratograma de raio-X para a lâmina tratada com etilenoglicol. 97

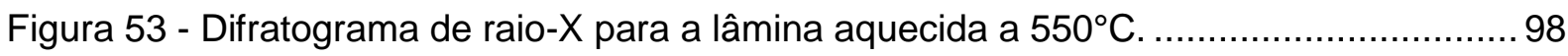

Figura 54 - Porosimetria do solo compactado em diferentes condições. 99

Figura 55 - Gradiente da massa específica seca: a) Grau de compactação e massa específica seca; b) coeficiente de variação.

Figura 56 - Massas específicas secas para cada uma das condições de compactação: (a) 5 camadas; (b) 7 camadas; (c) 7 camadas* (modificado); (d) 9 camadas e (e) 11 camadas.

Figura 57 - Corpos de prova utilizados nos ensaios de compressão confinada, bender elements, condutividade hidráulica e compressão triaxial.

Figura 58 - Curvas de compressão confinada para os corpos de prova talhados na direção vertical e horizontal.

Figura 59 - Módulos de compressão confinada $(D)$ para as amostras preparadas no ramo seco, umidade ótima e ramo úmido da curva de compactação.

Figura 60 - Efeito da tensão de confinamento na condutividade hidraulica na direção vertical

(V) e na direção horizontal $(\mathrm{H})$.

Figura 61 - Efeito da tensão de confinamento na relação de condutividade hidráulica na direção horizontal e vertical.

Figura 62 - Efeito da condição de moldagem, direção de fluxo e tensão de confinamento na condutividade hidráulica.

Figura 63 - Ensaios CU com amostras compactadas no ramo seco: (a) (b) tensãodeformação; (c) pressão da água intersticial.

Figura 64 - Ensaios CU com amostras compactadas na umidade ótima: (a) (b) tensãodeformação; (c) pressão da água intersticial.

Figura 65 - Ensaios CU com amostras compactadas no ramo úmido: (a) (b) tensãodeformação; (c) pressão da água intersticial.

Figura 66 - Trajetória de tensões efetivas: (a) ramo seco; (b) umidade ótima; (c) ramo úmido.

Figura 67 - Envoltória de resistência ao cisalhamento em termos de tensões efetivas com solo compactado no ramo seco para a representação $\left(\sigma_{1}-\sigma_{3}\right)$.

Figura 68 - Envoltória de resistência ao cisalhamento em termos de tensões efetivas com solo compactado na umidade ótima para a representação $\left(\sigma_{1}-\sigma_{3}\right)$.

Figura 69 - Envoltória de resistência ao cisalhamento em termos de tensões efetivas com solo compactado no ramo úmido para a representação $\left(\sigma_{1}-\sigma_{3}\right)$. 
Figura 70 - Envoltória de resistência ao cisalhamento em termos de tensões efetivas com solo compactado no ramo úmido para a representação $\left(\sigma_{1_{1}}^{\prime} / \sigma_{3}^{\prime}\right)$.

Figura 71 - Envoltória de resistência ao cisalhamento em termos de tensões efetivas com solo compactado na umidade ótima para a representação $\left(\sigma_{1}^{\prime} / \sigma_{3}^{\prime}\right)$.

Figura 72 - Envoltória de resistência ao cisalhamento em termos de tensões efetivas com solo compactado no ramo úmido para a representação $\left(\sigma_{1}^{\prime} / \sigma_{3}^{\prime}\right)$.

Figura 73 - Envoltória de resistência ao cisalhamento em termos de tensões totais com solo compactado no ramo seco para a representação $\left(\sigma_{1}-\sigma_{3}\right)$.

Figura 74 - Envoltória de resistência ao cisalhamento em termos de tensões totais com solo compactado na umidade ótima para a representação $\left(\sigma_{1}-\sigma_{3}\right)$.....

Figura 75 - Envoltória de resistência ao cisalhamento em termos de tensões totais com solo compactado no ramo úmido para a representação $\left(\sigma_{1}-\sigma_{3}\right)$.

Figura 76 - Envoltória de resistência ao cisalhamento em termos de tensões totais com solo compactado no ramo seco para a representação $\left(\sigma_{1}^{\prime} / \sigma_{3}^{\prime}\right)$

Figura 77 - Envoltória de resistência ao cisalhamento em termos de tensões totais com solo compactado na umidade ótima para a representação $\left(\sigma_{1}^{\prime} / \sigma_{3}^{\prime}\right)$.

Figura 78 - Envoltória de resistência ao cisalhamento em termos de tensões totais com solo compactado no ramo úmido para a representação $\left(\sigma_{1}^{\prime} / \sigma_{3}^{\prime}\right)$.

Figura 79 - Envoltória de resistência ao cisalhamento em termos de tensões efetivas. ..... 121

Figura 80 - Variação da resistência não drenada normalizada pela tensão de confinamento.

Figura 81 - Resposta para ensaio com bender elements em solos compactados no ramo seco, umidade ótima e ramo úmido para direção vertical e horizontal.

Figura 82 - Velocidade da onda de cisalhamento com bender elements para o solo compactado no ramo seco (RS), umidade ótima $(\mathrm{OU})$ e ramo úmido (RU).

Figura 83 - Efeito do teor de umidade no módulo de cisalhamento máximo nos corpos de prova talhados na direção vertical e horizontal.

Figura A1 - Esquema utilizado na divisão das camadas do corpo de prova compactado...147

Figura A2 - Comparativo entre as tendências de sub-compactação. 


\section{LISTA DE TABELAS}

Tabela 1 - Ensaios de laboratório mais utilizados para determinação do módulo de cisalhamento e da razão de amortecimento dos solos (BARROS; $\mathrm{HACHICH,} \mathrm{1998)}$

Tabela 2 - Influência do método de compactação na anisotropia de resistência dos solos (CRISPIM, 2010)

Tabela 3 - Valores de azul de metileno e atividade da fração argila em função da superfície específica 70

Tabela 4 - Índices físicos alvo para a compactação das amostras...................................... 73

Tabela 5 - Alturas iniciais em milímetro de cada camada das amostras compactadas ........ 76

Tabela 6 - Propriedades geotécnicas do solo estudado ................................................. 90

Tabela 7 - Resultados dos ensaios da metologia MCT ................................................... 95

Tabela 8 - Resultados do ensaio de azul de metileno .......................................................96

Tabela 9 - Características dos corpos de prova utilizados nos ensaios de condutividade

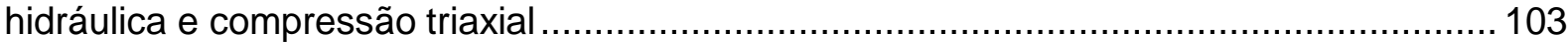

Tabela 10 - Características dos corpos de prova utilizados nos ensaios com bender

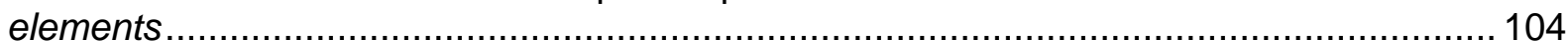

Tabela 11 - Características dos corpos de prova utilizados nos ensaios de compressão

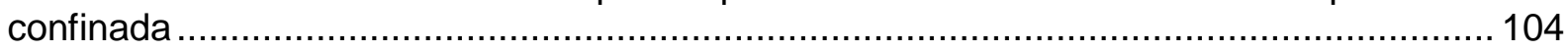

Tabela 12 - Resultados dos ensaios de compressão confinada..................................... 107

Tabela 13 - Parâmetros hidráulicos do solo para os corpos de prova talhados na direção

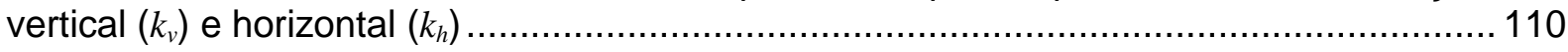

Tabela 14 - Parâmetros de ajuste da resistência não drenada do solo ............................. 124

Tabela A1 - Correção do gradiente de massa específica seca do corpo de prova intitulado 7 camadas* 



\section{LISTA DE SIGLAS E SÍMBOLOS}

\begin{tabular}{|c|c|c|}
\hline$\Delta$ & - & Variação \\
\hline$\varepsilon_{0}$ & - & Deformação no limiar do trecho elástico \\
\hline$\varepsilon_{a}$ & - & Deformação axial \\
\hline$\lambda$ & - & Comprimento da onda \\
\hline$\rho$ & - & Massa específica úmida \\
\hline$\rho_{d \max }$ & - & Massa específica seca máxima \\
\hline$\rho_{d m n}$ & - & Massa específica seca no ponto médio da camada $n$ \\
\hline$\rho_{\text {mold }}$ & - & Massa específica seca de moldagem (alvo) \\
\hline$\rho_{\text {par }}$ & - & Massa específica seca da água \\
\hline$\rho_{w}$ & - & Massa específica seca da parafina \\
\hline$\theta$ & - & $\begin{array}{l}\text { Ângulo formado entre o plano de orientação dos corpos de prova e o } \\
\text { plano de compactação, ângulo de reflexão do plano cristalino }\end{array}$ \\
\hline$\mu$ & - & Viscosidade do fluido percolante \\
\hline$\mu_{20}$ & - & Viscosidade do fluido percolante para $20^{\circ} \mathrm{C}$ \\
\hline$\rho_{s}$ & - & Massa específica dos sólidos \\
\hline$\sigma$ & - & Tensão normal \\
\hline$\sigma^{\prime}$ & - & Tensão normal efetiva \\
\hline$\sigma_{3}{ }^{\prime}-u_{a}$ & - & Tensão confinante liquida para o solo não saturado \\
\hline$\sigma_{1}$ & - & Tensão principal maior \\
\hline$\sigma_{3}$ & - & Tensão principal menor ou tensão confinante isotrópica \\
\hline$\sigma_{\text {ad }}^{\prime}$ & - & Tensão de pré-adensamento \\
\hline$\sigma_{\text {ad }}^{\prime}(c)$ & - & Tensão de pré-adensamento obtida pelo método de Casagrande \\
\hline$\sigma_{\text {ad }}^{\prime(p)}$ & - & Tensão de pré-adensamento obtida pelo método de Pacheco e Silva \\
\hline$\tau$ & - & Tensão cisalhante ou resistência ao cisalhamento \\
\hline$v$ & - & Coeficiente de Poisson \\
\hline$\phi$ & - & Ângulo de atrito interno em termos de tensões totais \\
\hline$\phi^{\prime}$ & - & Ângulo de atrito interno em termos de tensões efetivas \\
\hline $\mathrm{Al}_{2} \mathrm{O}_{3}$ & - & Hidróxido de alumínio \\
\hline$A$ & - & Área transversal do corpo de prova \\
\hline
\end{tabular}




\begin{tabular}{|c|c|c|}
\hline ABNT & - & Associação Brasileira de Normas Técnicas \\
\hline$A R$ & - & Agregação relative medida na curva de distribuição granulométrica \\
\hline ASTM & - & American Society for Testing and Materials \\
\hline$A c b$ & - & Atividade da fração argila \\
\hline $\bar{B}$ & - & Parâmetro de saturação de Skempton \\
\hline CBR & - & California Bearing Ratio \\
\hline $\mathrm{CP}$ & - & Corpo de prova talhado \\
\hline CTC & - & Capacidade de troca catiônica \\
\hline $\mathrm{CV}$ & - & Coeficiente de variação \\
\hline $\mathrm{CU}$ & - & Ensaio de compressão triaxial do tipo consolidado não drenado \\
\hline$C$ & - & Concentração da solução \\
\hline$C_{\mathrm{c}}$ & - & Índice de compressão \\
\hline$C_{\mathrm{r}}$ & - & Índice de recompressão \\
\hline$C_{\mathrm{s}}$ & - & Índice de expansão \\
\hline$c_{u}$ & - & Resistência não drenada \\
\hline$c$ & - & Intercepto coesivo em termos de tensões totais \\
\hline$c^{\prime}$ & - & Intercepto coesivo em termos de tensões efetivas \\
\hline$d$ & - & Distância interplanar basal \\
\hline$D$ & - & Diâmetro, Módulo de compressão confinada, Razão de amortecimento \\
\hline$e$ & - & Índice de vazios \\
\hline E & - & Módulo longitudinal ou módulo de Young \\
\hline$E_{0}, E_{\max }$ & - & Módulo longitudinal máximo \\
\hline$E_{0 h}$ & - & Módulo longitudinalmáximo no plano horizontal \\
\hline$E_{0 v}$ & - & Módulo longitudinal máximo no plano vertical \\
\hline$E_{\mathrm{sec}}$ & - & Módulo longitudinal secante \\
\hline$E_{\text {tan }}$ & - & Módulo longitudinal tangente \\
\hline $\mathrm{F}_{2} \mathrm{O}_{3}$ & - & Óxido de ferro \\
\hline GC & - & Grau de compactação \\
\hline$G$ & - & Módulo transversal ou de cisalhamento \\
\hline$G_{\max }, G_{0}$ & - & Módulo de cisalhamento máximo \\
\hline$G_{0 h}$ & - & Módulo de cisalhamento no plano horizontal \\
\hline$G_{0 v}$ & - & Módulo de cisalhamento no plano vertical \\
\hline$G_{\text {sec }}$ & - & Módulo de cisalhamento secante \\
\hline
\end{tabular}




\begin{tabular}{|c|c|c|}
\hline$h$ & - & Carga hidráulica \\
\hline$h_{n}$ & - & Posição final da camada $n$ \\
\hline$h_{n} *$ & - & Posição final corrigida da camada $n$ \\
\hline$h_{m n}$ & - & Posição do ponto médio da camada $n$ \\
\hline$H$ & - & Altura do corpo de prova \\
\hline IFSC & - & Instituto de Física de São Carlos \\
\hline$i$ & - & Gradiente hidráulico \\
\hline$I_{p}$ & - & Índice de plasticidade \\
\hline$k$ & - & Condutividade hidráulica \\
\hline$k_{h}$ & - & Condutividade hidráulica horizontal \\
\hline$k_{v}$ & - & Condutividade hidráulica vertical \\
\hline$k_{h} / k_{v}$ & - & Anisotropia de condutividade hidráulica \\
\hline$k_{20}$ & - & Condutividade hidráulica corrigida para $20^{\circ} \mathrm{C}$ \\
\hline$L$ & - & Comprimento \\
\hline$L A^{\prime}$ & - & Laterítico arenoso \\
\hline$L_{t t}$ & - & Comprimento \\
\hline$m$ & - & Parâmetro de ajuste \\
\hline$M$ & - & Massa \\
\hline$M_{s}$ & - & Massa seca do solo \\
\hline MCT & - & Miniatura, Compactado, Tropical \\
\hline MEV & - & Microscopia Eletrônica de Varredura \\
\hline$n$ & - & Porosidade; Número da camada selecionada \\
\hline$n_{t}$ & - & Número total de camadas \\
\hline OCR & - & Over Consolidation ratio \\
\hline NBR & - & Norma Brasileira de Regulamentação \\
\hline$p(<0,005)$ & - & Fração da amostra menor que $0,005 \mathrm{~mm}$ \\
\hline$P$ & - & Onda de compressão \\
\hline$P_{i}$ & - & Perda de massa por imersão \\
\hline $\mathrm{pH}$ & - & Potencial hidrogeniônico \\
\hline PIM & - & Porosimetria por Intrusão de Mercúrio \\
\hline PVC & - & Policloreto de Vinila \\
\hline$q$ & - & Vazão \\
\hline
\end{tabular}




\begin{tabular}{|c|c|c|}
\hline RS & - & Ramo seco \\
\hline RU & - & Ramo úmido \\
\hline$R^{2}$ & - & Coeficiente de determinação \\
\hline$R_{T}$ & - & Razão de viscosidade da água para a temperatura do ensaio e para $20^{\circ} \mathrm{C}$ \\
\hline$S$ & - & Onda de cisalhamento; parâmetro de ajuste \\
\hline$S_{n}$ & - & Fator de sub-compactação \\
\hline SE & - & Superfície específica do material \\
\hline$s$ & - & Abscissa do ponto da trajetória de tensões totais \\
\hline$s^{\prime}$ & - & Abscissa do ponto da trajetória de tensões efetivas \\
\hline$S_{r}$ & - & Grau de saturação \\
\hline$T$ & - & Temperatura média da água \\
\hline TRB & - & Transportation Research Board \\
\hline$t$ & - & Ordenada do ponto da trajetória de tensões, tempo \\
\hline$u$ & - & Pressão da água intersticial ou pressão neutra \\
\hline$u_{a}-u_{w}$ & - & Sucção \\
\hline USP & - & Universidade de São Paulo \\
\hline $\mathrm{UO}$ & - & Umidade ótima \\
\hline USCS & - & Unified Soil Classification System \\
\hline$v$ & - & Velocidade \\
\hline$V$ & - & Volume \\
\hline$V_{b}$ & - & Valor de azul de metileno \\
\hline$V_{s}$ & - & Velocidade da onda de cisalhamento \\
\hline$V_{s h}$ & - & Velocidade da onda de cisalhamento propagada no plano horizontal \\
\hline$V_{s v}$ & - & Velocidade da onda de cisalhamento propagada no plano vertical \\
\hline$w$ & - & Teor de umidade gravimétrico \\
\hline$w_{s}$ & - & Limite de contração \\
\hline$w_{L}$ & - & Limite de liquidez \\
\hline$w_{\text {mold }}$ & - & Teor de umidade de moldagem (alvo) \\
\hline$w_{o t}$ & - & Teor de umidade ótima \\
\hline$w_{P}$ & - & Limite de plasticidade \\
\hline$W^{a g}$ & - & Ordenada acurva de distribuição granulométrica sem defloculante \\
\hline$W^{i}$ & - & Ordenada acurva de distribuição granulométrica com defloculante \\
\hline
\end{tabular}


- Logaritmo do tamanho de partícula mínimo da curva de distribuição granulométrica

$x_{f} \quad$ - Logaritmo do tamanho de partícula máximo da curva de distribuição granulométrica 



\section{ÍNDICE}

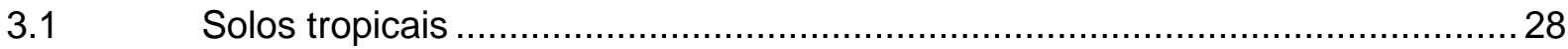

3.1.1 Processo de laterização …............................................................. 30

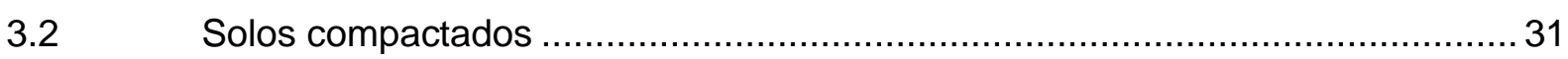

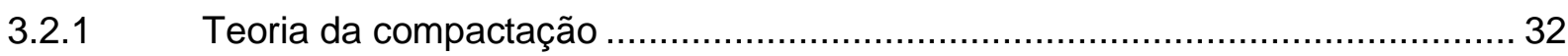

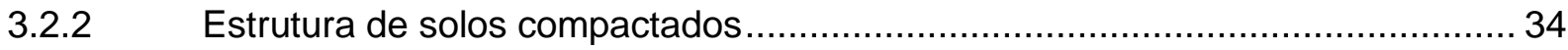

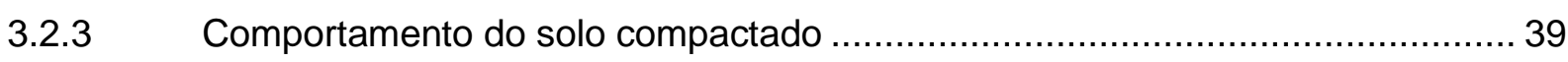

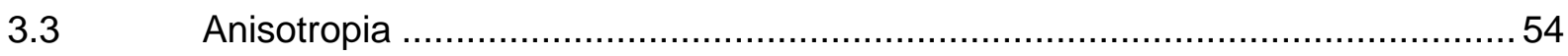

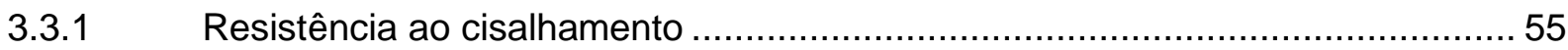

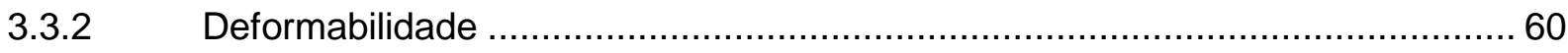

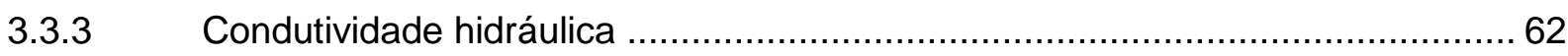

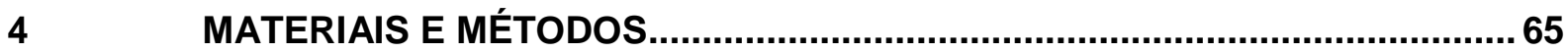

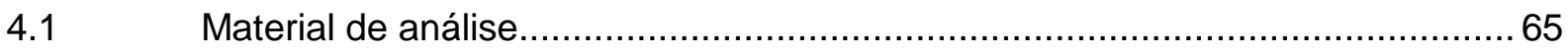

4.2 Ensaios de caracterização geotécnica e compactação .....................................66

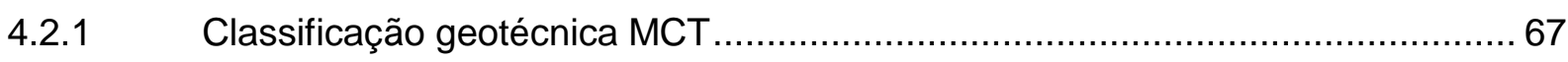

4.3 Caracterização físico-química e mineralógica................................................ 69

4.3.1 Ensaio de Adsorção de Azul de Metileno..................................................... 69

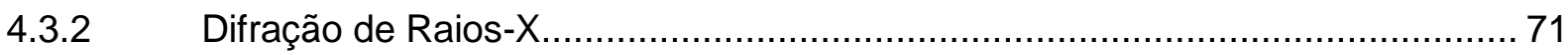

Ensaios de Porosimetria por Intrusão de Mercúrio ….................................... 72

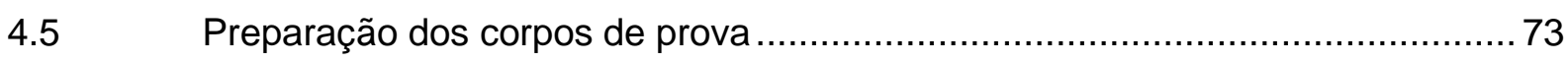

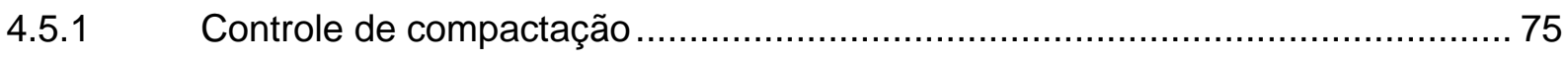

4.5.2 Condutividade hidráulica, compressão triaxial e bender elements..................... 78

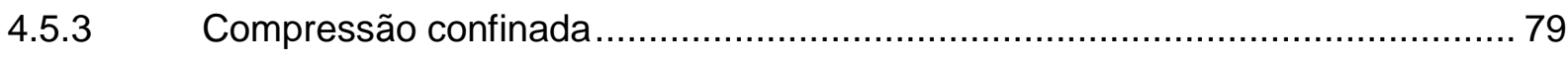

4.5.4 Porosimetria por intrusão de mercúrio …...................................................... 80 
Ensaio de compressão confinada ................................................................. 81

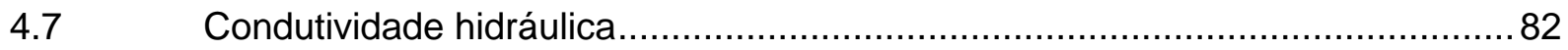

Ensaio de compressão triaxial ......................................................... 86

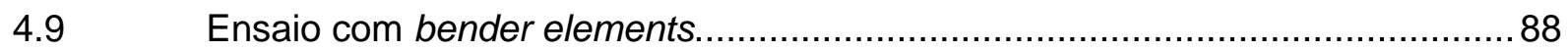

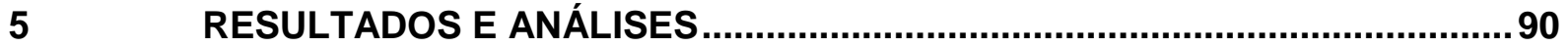

5.1 Caracterização geotécnica e compactação..................................................90

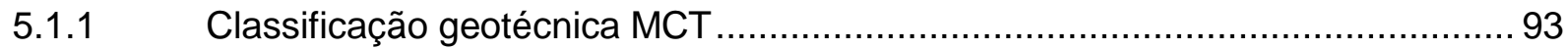

5.2 Caracterização físico-química e mineralógica .................................................95

5.2.1 Capacidade de troca catiônica (CTC) …....................................................... 96

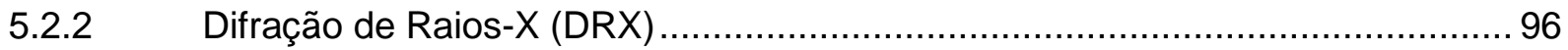

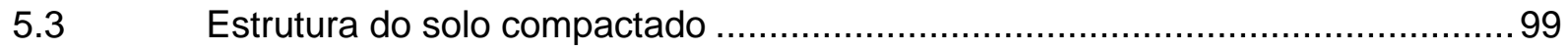

5.4 Influência do número de camadas no gradiente da massa específica seca das amostras................................................................................................... 100

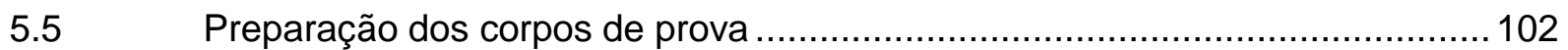

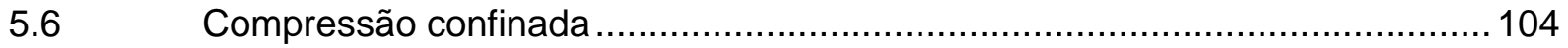

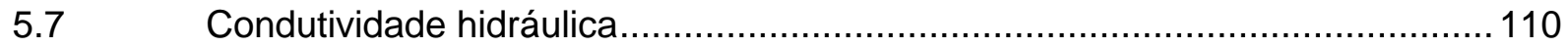

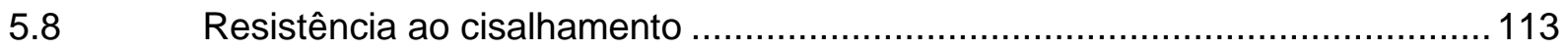

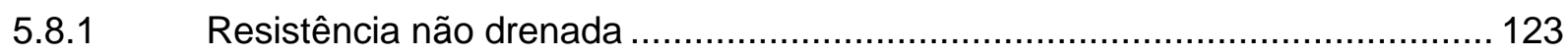

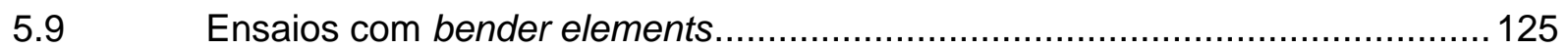

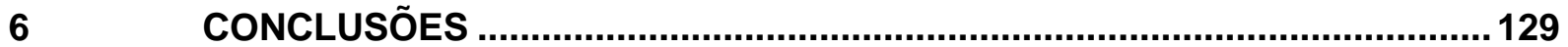

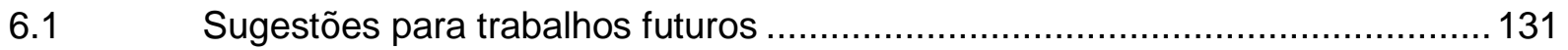

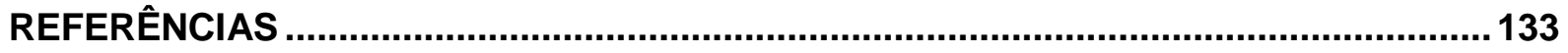

APÊNDICE A: METODOLOGIA PARA CORREÇÃO DO GRADIENTE DE MASSA ESPECÍFICA SECA 


\section{INTRODUÇÃO}

Na prática da engenharia geotécnica, o solo de um determinado local pode não atender os requisitos necessários para uma obra. Nesse quesito, pode-se lançar mão da técnica de compactação no intuito de conferir ao solo características que o torne, por exemplo, mais resistente, menos compressível, menos erodível, entre outros aspectos.

Proctor (1933) apresentou uma análise crítica sobre o comportamento dos solos compactados em laboratório, observando que a massa específica seca é função direta da condição de umidade, para certa energia aplicada. Esta informação, entre outras, forneceram subsídio para o uso racional da técnica de compactação e consequente normatização do ensaio no mundo.

Com base em diversos estudos sobre o tema observou-se que o teor de umidade de compactação tem influencia direta nas propriedades hidráulicas e mecânicas de materiais terrosos. De certo, estas diferenças estão associadas à influência do teor de umidade de compactação na organização das partículas e poros do solo. Por isso, por mais que a análise do solo em obras de terra normalmente o considere como um meio continuo, deve-se levar em consideração o formato, o tamanho e a organização de suas partículas e suas inferências nas propriedades geomecânicas de modo geral.

Uma das consequências da distribuição de partículas e poros diz respeito a formação de estrutura não homogênea, o que pode gerar alguma influência da orientação de amostragem na obtenção das propriedades geomecânicas do solo compactado. Por sua vez, o solo cujas propriedades de interesse dependem da orientação de amostragem, passam a não desempenhar comportamento isotrópico, uma vez que a orientação preferencial das partículas promove a formação de estruturas do tipo anisotrópica.

Diversos fatores estão associados à formação de estruturas anisotrópicas, como: deposição horizontal das partículas, consolidação anisotrópica, e compactação de aterros (MITCHELL; SOGA, 2005). A orientação da amostragem em aterros anisotrópicos compactados pode comprometer a previsão do desempenho das obras de terra ao longo da sua vida útil visto que, na maioria dos casos, a direção de amostragem é ortogonal ao plano de compactação. Sendo assim, torna-se importante avaliar os parâmetros que interferem diretamente no desempenho de obras de terra e, suas implicações quanto aos condicionantes que interferem na anisotropia do solo. Em vista disso, diversos autores investigaram o efeito da anisotropia na resistência na resistência ao cisalhamento dos solos compactados (KIM, 1996; KONGSUKPRASERT; SANO; TATSUOKA, 2007; ROWSHANZAMIR; ASKARI, 2010; HAM et al., 2012; DA FONSECA; RIOS; AMARAL, 2013). 
Além das propriedades mecânicas do solo, as propriedades hidráulicas também são afetadas pela formação de estruturas anisotrópicas. Além disso, imperfeições presentes na interface entre as camadas, também podem contribuir para um aumento significativo da condutividade hidráulica na direção paralela ao plano de compactação. $\mathrm{Na}$ maioria dos casos, a estrutura do solo compactado se encontra intimamente relacionada ao teor de umidade de compactação, o que contribui diretamente na anisotropia de condutividade hidráulica, que por sua vez, tende a aumentar com o acréscimo do teor de umidade de compactação (BOYNTON; DANIEL, 1985). A estrutura atribuída à variação do teor de umidade de compactação também é função da mineralogia e, dos processos de intemperismo envolvidos durante a formação do solo, o que por consequência, interfere a sua condutividade hidráulica. Por isso, o comportamento hidráulico de solos fortemente intemperizados foram temas de diversas pesquisas, que se propuseram a avaliar o papel do arranjo estrutural nas propriedades hidráulicas de solos lateríticos compactados (OSINUBI; NWAIWU, 2002, 2005, 2006).

As propriedades deformacionais do solo compactado também são fortemente dependentes da disposição espacial das partículas e poros que o constituem. De maneira geral, o solo compactado, quando solicitado a pequenas deformações, se comporta de maneira anisotrópica (JIANG et al., 1997; NG; YUNG, 2008). Geralmente, ao longo da sua vida útil, uma superestrutura transfere ao solo carregamentos que o solicita a pequenas deformações. Para se avaliar estas deformações, pode ser utilizada a propagação de ondas de cisalhamento por meio da técnica de bender elements, a qual tem se mostrado uma alternativa simples e versátil no cálculo do módulo de deformabilidade em pequenas deformações (HEITOR et al., 2013). Por outro lado, esta técnica ainda é pouco aplicada em solos tropicais compactados, o que implica em uma quantidade reduzida de trabalhos sobre o tema. (GEORGETTI, 2014).

Recentemente, diversos trabalhos se dispuseram a avaliar comportamento geotécnico de solos tropicais compactados (OTÁLVARO, 2013; BORGES, 2014), uma vez que estes materiais têm se mostrado uma excelente alternativa na construção de barragens, ferrovias e bases de aterros rodoviários (NOGAMI; VILLIBOR, 1995). Neste sentido, a presente pesquisa deu continuidade aos trabalhos já desenvolvidos na Escola de Engenharia de São Carlos (EESC/USP) na avaliação das propriedades de solos arenosos lateríticos compactados, típicos do estado de São Paulo. Dentro desse contexto, comprometeu-se a estudar o efeito do teor de umidade de compactação e da orientação de talhagem dos corpos de prova na obtenção dos parâmetros hidráulicos, mecânicos e deformacionais destes solos. Dessa maneira, os resultados desta pesquisa podem servir de referência ao meio prático e acadêmico como critério de seleção e/ou de projetos em que se utilizem solos lateríticos como material de construção. 


\section{OBJETIVO}

Esta investigação discute aspectos relacionados ao comportamento mecânico, hidráulico e deformacional em três distintas condições sob a curva de compactação, com objetivo de avaliar o efeito da condição de umidade na estrutura e na anisotropia inerente produzida pela compactação, em um solo arenoso fino laterítico proveniente do interior do Estado de São Paulo, Brasil. Para alcançar o objetivo principal desta pesquisa foram definidos os objetivos específicos, a saber:

- $\quad$ classificação geotécnica e mineralógica do solo;

- $\quad$ adequação de método de compactação das amostras para talhagem de corpos de prova homogêneos e representativos das condições esperadas;

- $\quad$ estudo da influência do teor de umidade de compactação nos parâmetros ligados a: (i) resistência ao cisalhamento, (ii) deformabilidade, (iii) condutividade hidráulica e (iv) compressibilidade;

- $\quad$ análise estrutural quantitativa a fim de entender como o teor de umidade de compactação altera a macroestrutura e a microestrutura do solo compactado. 


\section{REVISÃO BIBLIOGRÁFICA}

\subsection{Solos tropicais}

O conceito de solos pode se diferenciar em função, principalmente, da área de atuação do estudo, seja ela geológica ou de engenharia, por exemplo. Para aplicação em obras de engenharia civil, o solo pode ser considerado qualquer acumulação, formada por partículas minerais e vazios preenchidos por água ou ar. Tal organização depende dos processos envolvidos durante a sua formação e está diretamente associada ao intemperismo da rocha.

O intemperismo é um processo de decomposição e desagregação da rocha, sendo causado pela ação química, física e biológica. A desintegração física ocorre pela ação da água, pela variação da temperatura, ação de vegetais (raízes), entre outros. A decomposição química ocorre principalmente por meio da ação da água que modifica química e mineralogicamente a rocha, mediante fenômenos envolvendo: hidrólise, hidratação, carbonatação e oxidação (CHIOSSI, 2013). Assim, o processo de formação dos solos ocorre em função dos agentes de alteração aplicados à rocha mãe (CAPUTO, 1988).

Dentre os tipos citados, o intemperismo químico é aquele mais pronunciado em climas tropicais, devido às elevadas temperaturas, acompanhadas de chuvas frequentes nestas regiões (PINTO, 2006). No Brasil, em razão de sua localização geográfica, os solos tropicais são encontrados em maior abundância.

Os solos tropicais podem ser categorizados em dois grandes grupos, a depender do grau de alteração e dos fatores pedogenéticos associados: solos lateríticos e solos saprolíticos (NOGAMI; VILLIBOR, 1995).

É possível por meio da classificação pedológica descrever os solos de características lateríticas como: solos superficiais expostos em condições bem drenadas, estando localizados em região de clima tropical úmido (NOGAMI; VILLIBOR, 1995). Os mesmos autores definiram solos saprolíticos como: solos originados pelo desgaste in situ da rocha, que se encontra em um estágio avançado de desintegração, o qual se assemelha bastante a estrutura original da rocha pretérita.

Wesley (2009) ressaltou que a topografia tem grande influência no processo de intemperismo, visto que ela se encontra diretamente relacionada às condições de drenagem. Áreas bem drenadas favorecem a formação de argilominerais da família da caulinita, enquanto em regiões mal drenadas ocorre a formação de minerais da família da esmectita (NOGAMI; VILLIBOR, 1995). As regiões bem drenadas, onde se formam 
argilomineirais de baixa atividade, como a caulinita, possuem boas propriedades para aplicação na engenharia.

A respeito do volume e da organização dos solos e/ou rochas presentes nos perfis encontrados em regiões de clima tropical, Nogami e Villibor (1995) ressaltaram que:

- solos lateríticos localizados em grandes extensões de horizontes superficiais apresentam, aproximadamente um metro de espessura, podendo chegar até dezenas de metros;

- solos saprolíticos localizados em grandes extensões de horizontes superficiais podem chegar a dezenas de metros de espessura;

- outra possível situação relaciona-se aos solos transportados. Os solos originados na época Holoceno (Período Quaternário) e os solos oriundos do Neógeno (Período Terciário) ocupam posições topograficamente mais elevadas que aquelas prevalecentes no período de formação (ambiente fluvial e fluvio-lacustre).

Em termos microestruturais verificou-se, por meio de Microscopia Eletrônica de Varredura (MEV), que o intemperismo gera solos com estruturas nitidamente diferentes. Observa-se pela Figura 1 que no solo fortemente intemperizado (Figura 1a) formam-se agregações dando origem a macroporos, típicas de solo laterítico. Uma elevada presença de macroporos, indica uma estrutura porosa com alto índice de vazios. Já no solo pouco intemperizado (Figura 1b) é possível notar que as partículas são organizadas em formas de pacotes isolados, formando macroporos entre agregações típicas de solos saprolíticos. Em outras palavras, enquanto solos profundamente intemperizados apresentam maior concentração de macroporos na sua estrutura, nos solos pouco intemperizados a concentração de microporos são maiores.
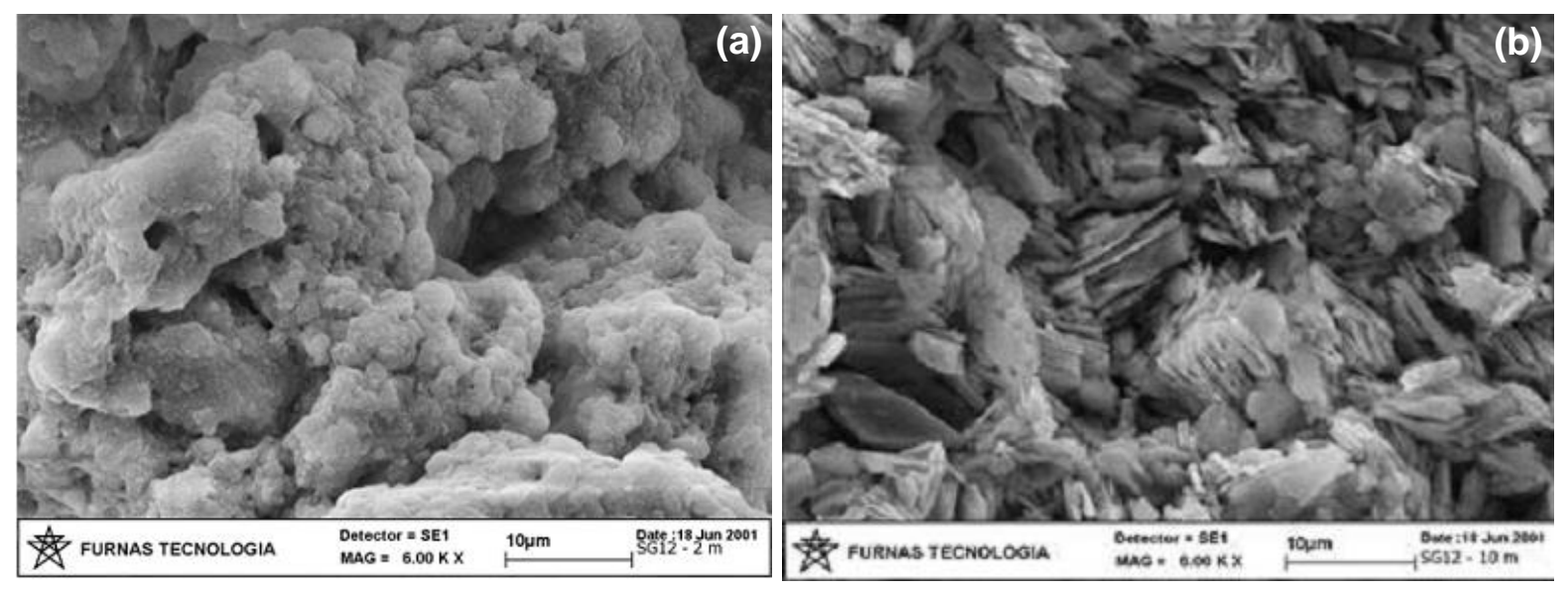

Figura 1 - Estrutura de amostras indeformadas de solos tropicais: a) fortemente intemperizado; b) pouco intemperizado. (CAMAPUM DE CARVALHO et al., 2012). 
Em resumo, a formação dos solos lateríticos está intimamente relacionada à gênese, grau de intemperismo, características morfológicas, químicas e mineralógicas do sistema em questão (GIDIGASU, 1976). Assim, o entendimento do processo de laterização destes solos auxilia a sua aplicação e o seu desempenho em obras de engenharia.

\subsubsection{Processo de laterização}

A laterização é um fenômeno característico de regiões de clima tropical (quente e úmido), onde ocorre uma acumulação de sesquióxidos ${ }^{1}$ de ferro e alumínio aumentando os teores destes elementos à custa do processo de lixiviação nos materiais mais solúveis, incluindo a sílica (BARATA, 1981).

Gidigasu (1976) listou três estágios tidos como básicos no processo de laterização.

O primeiro estágio é caracterizado pela decomposição físico-química dos minerais primários da rocha, seguidos da liberação dos elementos constituintes. Alguns minerais não sofrem decomposição nesta etapa devido a diversos fatores, um destes minerais é o quartzo, por ser altamente estável.

No segundo estágio ocorre a lixiviação, sob condições de drenagem de sílica e bases acompanhada de acumulação de sesquióxidos $\left(\mathrm{Al}_{2} \mathrm{O}_{3}\right.$ e $\left.\mathrm{F}_{2} \mathrm{O}_{3}\right)$. No entanto, o efeito da lixiviação depende do $\mathrm{pH}$ da água, nível d'agua e propriedades químicas dos minerais primários.

A origem destes sesquióxidos pode ser entendido por meio de duas teorias. Uma delas refere-se a acumulação relativa de óxidos como resultado da perda progressiva da sílica solúvel em solução alcalina, garantindo a permanência da caulinita e dos óxidos de ferro/alumínio (BARROS, 1985). Este processo pode ser o responsável pelas elevadas porosidades observadas em solos lateríticos. A outra teoria defende que a lixiviação pode ser originada a partir da precipitação de óxidos de alumínio e de ferro trazidos pela água.

Enfim, a formação do solo por lixiviação produz minerais derivados dos óxidos de alumínio (gibbsita) e de óxidos e hidróxidos de ferro (limonita e goetita). Além disso, é comum nesse tipo de solo a presença de caulinita e, para rochas que contem quartzo, a presença de fração areia.

O terceiro estágio do processo de laterização remete a fase de desidratação em condições de intenso a prolongado intemperismo dos minerais primários (GIDGASU, 1976).

\footnotetext{
${ }^{1}$ Sesquióxidos são óxidos que possuem três átomos de oxigênio ligados a dois átomos de outro elemento, por exemplo, o óxido de alumínio $\mathrm{Al}_{2} \mathrm{O}_{3}$ (GREENWOOD; EARNSHAW, 1984).
} 
Nesta fase, a destruição dos argilominerais é responsável pelo ressecamento e endurecimento dos sesquióxidos.

Em relação a coloração do solo, esta pode ser influenciada pela presença de minerais como: quartzo, caulinita, oxi-hidróxidos de ferro e de alumínio, além disso, o efeito do intemperismo no solo pode conferi-lo coloração amarela ou vermelha, típicas de regiões tropicais (TEIXEIRA, 2008).

\subsection{Solos compactados}

Devido às propriedades mecânicas e hidráulicas observadas em solos lateríticos apresentarem-se adequadas à construção de aterros compactados, se faz necessária uma revisão dos processos envolvidos na obtenção da curva de compactação em laboratório. A técnica de compactação foi pioneiramente desenvolvida pelo engenheiro Ralph Proctor e, consiste em determinar a massa específica seca e o teor de umidade para uma dada energia aplicada no solo (PROCTOR, 1933). Esta técnica foi empregada com o intuito de analisar o desempenho do solo, frente a energia aplicada pelas passadas do rolo compressor em campo. No Brasil, o ensaio de compactação é normatizado pela ABNT NBR 7186 (ABNT, 1986).

A Figura 2 mostra que a curva de compactação é representada pela variação da massa específica seca em função do teor de umidade de compactação. Nota-se que para teores de umidade menores que o teor ótimo $\left(w_{\mathrm{ot}}\right)$ a massa específica tende a diminuir com o decréscimo do teor de umidade (ramo seco), e para teores de umidade maiores que o correspondente ao teor ótimo, a massa específica seca também decresce (ramo úmido). $\mathrm{Na}$ maioria dos solos, a curva de compactação apresenta formato parabólico, com exceção de solos lateríticos que apresentam ramo seco com maior inclinação (PINTO, 2006).

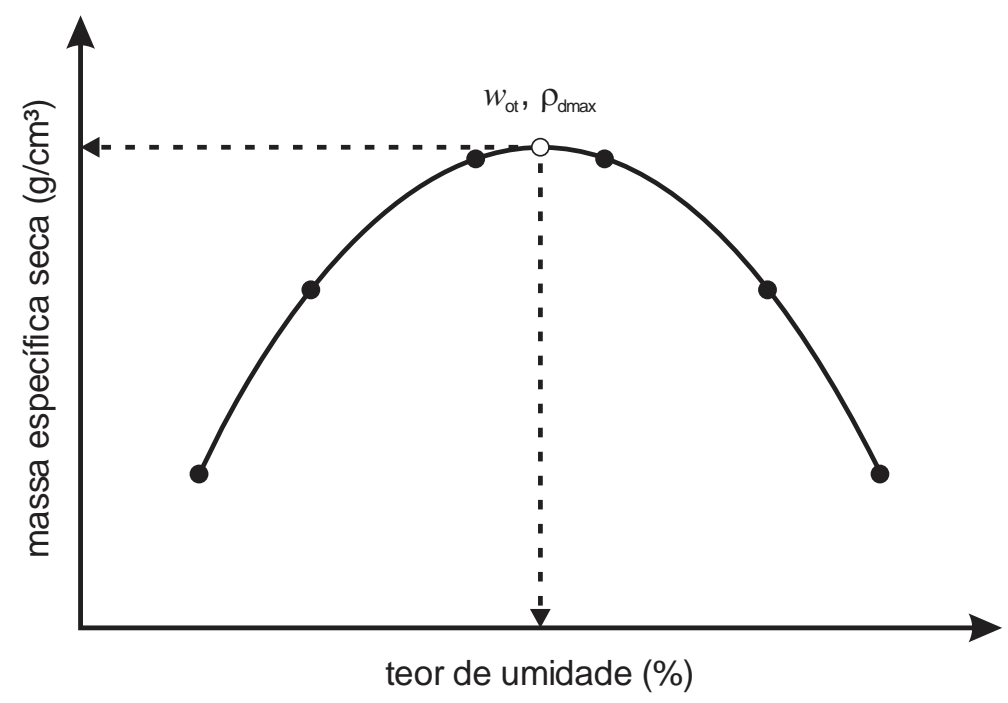

Figura 2 - Curva de compactação. 


\subsubsection{Teoria da compactação}

Desde as considerações propostas por Proctor (1933), diversos autores se dispuseram a estudar o formato da curva de compactação, desenvolvendo justificativas para este comportamento. Hilf (1991) apresentou uma visão crítica a respeito das principais teorias desenvolvidas até o momento para aplicação em solos coesivos, sendo possível destacar:

\section{Teoria de Proctor}

Proctor $^{2}$ (1933 apud HILF, 1991) retratou a curva de compactação como um processo que se diferencia em função do ramo a ser analisado. No ramo seco são geradas elevadas forças de atrito advindas de tensões capilares resistentes aos esforços de compactação, sendo possível assim, obter maiores índices de vazios. Por sua vez, o acréscimo de água no solo gera lubrificação das partículas diminuindo o efeito das tensões capilares e o atrito entre partículas. Por consequência, a adição de água no solo implica em sucessivas reduções do índice de vazios até o momento em que esse é mínimo, nesse ponto, é obtida a massa específica seca máxima para um teor de umidade ótimo; já no ramo úmido a massa específica seca diminui, justificada pelo afastamento inter-partículas.

\section{Teoria de Hogentogler}

Hogentogler $^{3}$ (1936 apud HILF, 1991) considerou que a forma da curva de compactação reflete quatro estágios de umidade, sendo eles: hidratação, lubrificação, inchamento e saturação. Na fase de hidratação ocorre a adsorção de água pelas partículas, formando uma espécie de "filme", sendo a água considerada altamente viscosa. Com adição de água esse "filme" facilita o rearranjo das partículas até o estágio chamando lubrificação limite. A partir desse ponto, superiores adições de água causam inchamento da massa de solo provocando o deslocamento entre partículas sem mudança da quantidade de ar existente na lubrificação limite. Na última fase, o autor considera que o sucessivo inchamento leva o solo a completa saturação.

\footnotetext{
${ }^{2}$ PROCTOR, R. R. The design and construction of rolled Earth dams. Engineering News-Record, III, August 31, September 7, 21, and 28. 1933.

${ }^{3}$ HOGENTOGLER, C. A. Essentials of soil compaction, Proceedings of the Highway Research

Board, National Research Council, Washington, D.C., pp. 309-316. 1936.
} 


\section{Teoria de Hilf}

Hilf $^{4}$ (1956 apud HILF, 1991) retratou a curva de compactação em termos de capilaridade e pressão na fase gasosa do solo. Assim, para baixos teores de umidade, são formados meniscos com pequenos diâmetros, elevando as forças de atrito entre as partículas de solo, e consequentemente facilitando a expulsão de ar dos vazios. Com a progressiva adição de água, os raios dos meniscos aumentam, dificultando a expulsão de ar nos teores de umidade próximos ao ótimo, por outro lado, o solo passa a perder sua capacidade de absorver os esforços de compactação. No ramo úmido a redução da massa específica seca do solo é atribuída ao aprisionamento do ar nos poros, remetendo a certa ineficiência no processo de compactação.

\section{Teoria de Lambe}

Lambe $^{5}$ (1960 apud HILF, 1991) analisou a curva de compactação sobre os aspectos da interação físico-química das partículas. Para solos com baixos teores de umidade ocorrem elevadas concentrações eletrolíticas, reduzindo as forças de repulsão osmótica entre as partículas, propiciando uma estrutura do tipo floculada. Com acréscimo do teor de umidade, e consequente diminuição da concentração eletrolítica, permite-se o desenvolvimento de uma dupla camada difusa. Esta situação propicia estruturas mais dispersas, diminuindo a concentração de sólidos, gerando estruturas menos densas e cada vez mais orientadas permitindo, assim, que as partículas deslizem umas sobre as outras.

\section{Teoria de Olson}

Olson $^{6}$ (1963 apud HILF, 1991) utilizou o princípio das tensões efetivas para investigar o comportamento da curva de compactação a partir de ensaios por pisoteamento em solo arenoso fino. No ramo seco da curva ocorre acréscimo de pressão na fase líquida e gasosa, e com isso é possível reduzir as tensões efetivas, promovendo um melhor entrosamento entre as partículas. À medida que se acrescenta água, ocorre um aumento da massa específica a fim de que as novas tensões efetivas resistam aos esforços de compactação impostos. Próximo ao teor de umidade ótimo, os vazios se tornam

\footnotetext{
${ }^{4}$ HILF, J. W. Na investigation of pore-water pressure in compacted cohesive soils. Denver Colorado: Technical Memorandum 654, U. S. Departament of the interior, Bureal of Reclamation. 1956.

${ }^{5}$ LAMBE, T.W. Structure of compacted clay. Transactions ASCE, 125, pp. 682-705. 1960.

${ }^{6}$ OLSON, R. R. Effective stress theory of soil compaction. Jornal of the Soil Mechanics and Fundation Division, ASCE, 89, № SM2, pp. 27-45, 1963.
} 
descontínuos, reduzindo a permeabilidade da fase ar e garantindo assim, a massa específica seca máxima.

\section{Teoria de Barden e Sides}

Barden e Sides $^{7}$ (1970 apud HILF, 1991), por meio de análises microscópicas na estrutura de uma argila compactada, observaram que o processo de compactação é justificado pela formação de agregações de partículas. Para baixos teores de umidade, as agregações são bastante rígidas a ponto de que sucessivas adições de água diminuam sua resistência e, consequentemente, reduzam seu índice de vazios. Esta redução é máxima no teor de umidade ótimo e, a partir desse ponto, a adição de água causa redução da massa específica seca devido principalmente ao aumento da presença de água entre as partículas de solo, causando descontinuidade na fase ar.

A partir do exposto, Hilf (1991) comentou que as hipóteses que consideram a determinação da curva de compactação um processo dependente das tensões efetivas, seja ela função da pressão capilar ou da formação de agregações, apresentam-se mais prováveis que do processo de lubrificação das partículas. No entanto, o mesmo autor não descartou nenhuma das hipóteses e, sugere que mais pesquisas sejam realizadas sobre 0 tema, a fim de compreender como a relação ar-água-solo interfere na obtenção da curva de compactação.

\subsubsection{Estrutura de solos compactados}

Conforme visto anteriormente, boa parte das teorias envolvendo a curva de compactação foram desenvolvidas com auxílio de técnicas que permitiram uma avaliação microestrutural do solo. Geralmente em obras de geotecnia, o solo é tratado como um meio continuo, todavia, o formato, o tamanho e a organização das partículas do solo influenciam de maneira significativa nas propriedades de interesse, tais como: permeabilidade, compressibilidade e resistência ao cisalhamento (MITCHELL; SOGA, 2005). Estes autores afirmaram que nem sempre é possível explicar o essas propriedades conhecendo, por exemplo, a granulometria, o limite de liquidez, o limite de plasticidade e, sugerem que algumas dessas propriedades sejam explicadas por meio de análise microscópica da estrutura do solo.

\footnotetext{
${ }^{7}$ BARDEN, L.; SIDES, G.R. Engineering behavior and struture of compacted clay. Journal of the soil Mechanics and Fundation Division, ASCE, 96, № SM4, p. 1171, 1970.
} 
Para a análise microscópica do solo é necessário que se conheça os conceitos de fábrica e estrutura. O termo fábrica, do inglês: fabric, é definido como o arranjo das partículas e poros presentes no solo, enquanto o termo estrutura, diz respeito às forças existentes entre as partículas, combinadas aos efeitos da fábrica (MITCHELL; SOGA, 2005; REIS, 2010). Assim, as partículas tendem a se estruturar de diferentes maneiras, em função do tipo e formato do argilomineral, teor de umidade, histórico de tensões, entre outros. No entanto, apesar da clara diferença entre os termos estrutura e fábrica, convencionou-se nesta pesquisa utilizar o termo estrutura para ambos os casos.

A estrutura pode ser agrupada a depender do tamanho do poro podendo ser dividido em 2 grupos, sendo eles: poros interagregados (macroporos) e intra-agregados (microporos). Para Delage e Lefebvre (1984) os poros interagregados refletem os vazios existentes entre agregados, enquanto os poros intra-agregados são aqueles formados entre partículas (Figura 3).

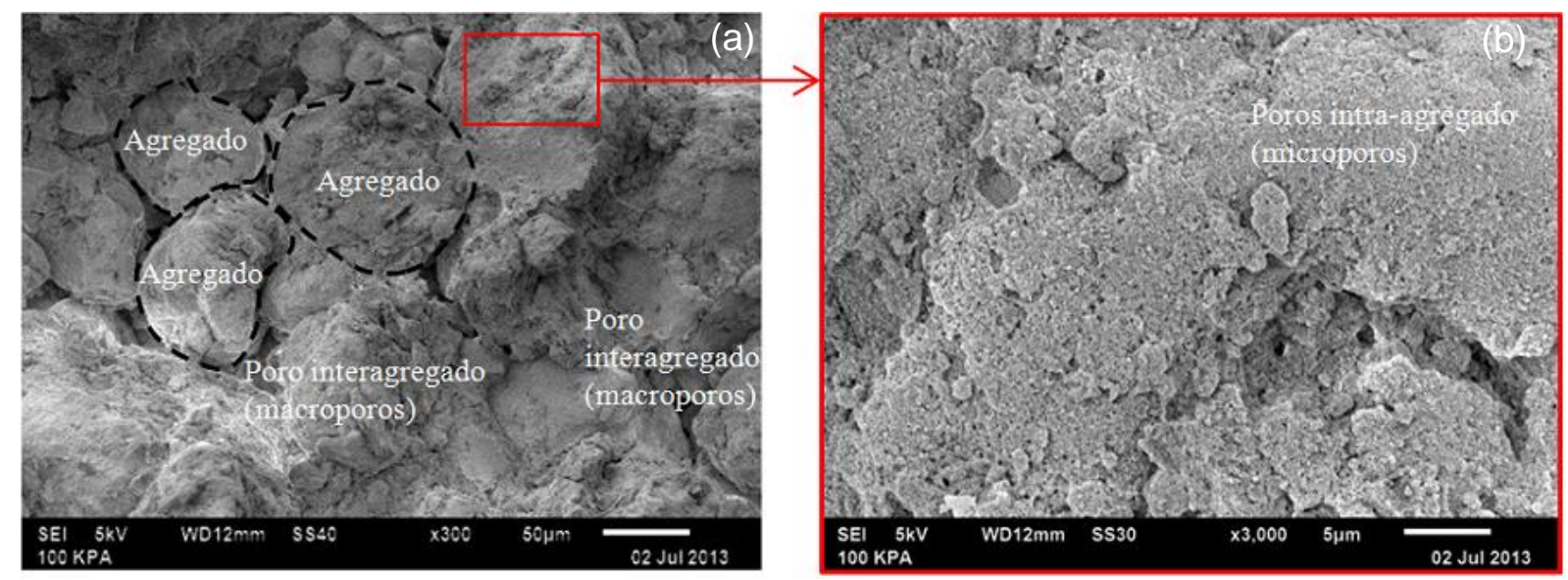

Figura 3 - Estrutura do solo compactado: (a) Interagregados (macroporos), e (b), Intra-agregados (microporos). (BORGES, 2014).

O tamanho dos poros é tema controverso em algumas pesquisas, contudo, independente da condição do solo (indeformada ou compactada), Romero (1999) definiu que os microporos são aqueles poros menores que $0,3 \mu \mathrm{m}$, enquanto os macroporos são maiores que este valor.

A estrutura também deve ser objeto de estudo quanto a sua influências nas propriedades do solo, desta forma, Juan e Holtz (1986) estudaram o efeito da estrutura na condutividade hidráulica dos solos compactados e afirmaram que, por mais que o solo tenha o mesmo índice de vazios, o mesmo pode apresentar arranjos diferentes (Figura 4), interferindo diretamente na condutividade hidráulica. Nota-se na Figura 4a uma maior quantidade de vazios interconectados favorecendo a condutividade hidráulica, enquanto que 
na Figura 4b observa-se o inverso, ou seja, devido a maior distribuição de vazios do solo a passagem de água é dificultada.
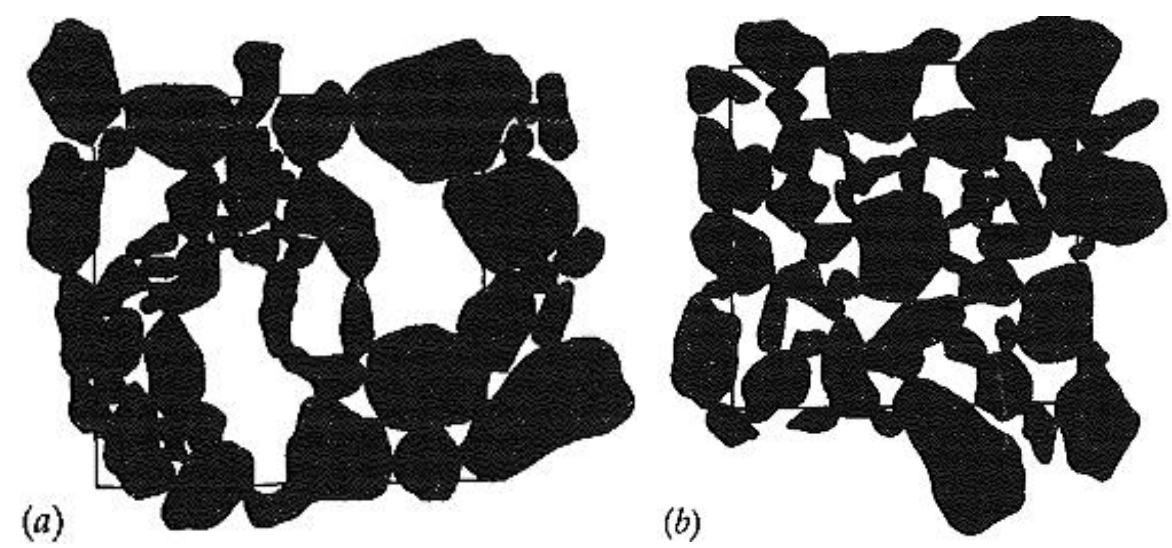

Figura 4 - Distintos arranjos de partículas com o mesmo índice de vazios e mesma densidade (Adaptada de JUANG; HOLTZ, 1986).

As estruturas de solos arenosos e argilosos são, em grande parte, diferentes entre si. Segundo Rico Rodriguez e Del Castillo (1992) a estrutura dos solos argilosos é mais complexa que a dos solos arenosos. Nos solos arenosos prevalece as pressões de contato grão a grão, sendo que o número de contatos é fator determinante na análise. Já em solos argilosos ocorre a formação de agregações devido às forças eletrostáticas que tendem a agrupar as partículas. Camapum de Carvalho et al. (2012) e Queiroz (2015) afirmaram que enquanto o comportamento do solo argiloso compactado é regido pela interação entre partículas, nas areias o predomínio das forças capilares é mais pronunciado. Os autores ainda observaram que em solos lateríticos, a teoria proposta por Lambe (1958) não é aceita, visto que as partículas de argila agregadas tendem a se comportar como solos granulares.

Além do tipo de solo, as condições de compactação também podem interferir na formação da sua estrutura. O processo de compactação pode promover a quebra das agregações presentes no solo, proporcionando alterações de ordem macro e microestrutural no material. Entretanto, em solos tropicais, os processos de compactação, escavação e transporte não são suficientes para alterar os poros intra-agregados do solo (microestrutura) (CRUZ; FERREIRA, 1993).

Diversos fatores contribuem para alterações micro e macroestruturais no solo. Queiroz (2015) e Bhasin (1975) afirmaram que o aumento da energia de compactação causa redução dos macroporos, embora o acréscimo da energia de compactação não seja suficiente para promover alteração dos microporos (FARIAS et al., 2011; ROMERO; DELLA VECCHIA; JOMMI, 2011; QUEIROZ, 2015). 
Consequentemente, o processo de compactação interfere diretamente nas propriedades hidráulicas e mecânicas do solo. A resistência ao cisalhamento e a deformabilidade de solos finos são funções do processo de compactação e do teor de umidade, interferindo diretamente nas pressões da água intersticial (ensaios não drenados) e, nas variações de volume desenvolvidas durante a fase cisalhamento (ensaios drenados) (CRISPIM, 2010).

A depender do método de compactação aplicado no solo, as deformações tornam sua estrutura mais ou menos orientada (HILF, 1991), isto pode ser observado na Figura 5. Nota-se que o método de compactação estático leva o solo à estruturas floculadas em qualquer condição de umidade, podendo atribuir este fenômeno aos baixos esforços de cisalhamento impostos no processo. Por outro lado, a compactação por pisoteamento gera estruturas floculadas no ramo seco, e altamente dispersas no ramo úmido. Por fim, na compactação dinâmica as estruturas resultantes do processo apresentam-se mais floculadas que na compactação por pisoteamento, sendo cada vez mais orientadas em função do aumento do teor de umidade.

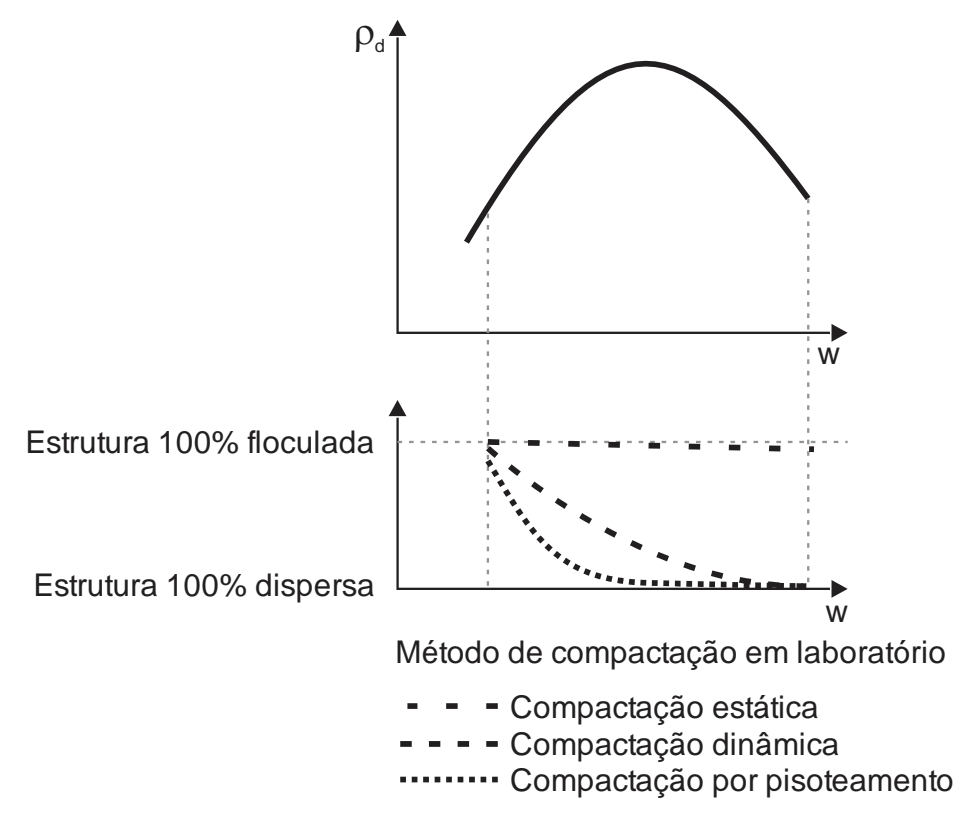

Figura 5 - Influência do tipo de compactação na estrutura dos solos compactados (Adaptada de MARANHA DAS NEVES, 1971).

A partir do exposto, nota-se a importância da análise microscópica da estrutura do solo compactado. Normalmente esta análise estrutural é realizada por meio de métodos quantitativos (PIM) e/ou qualitativos (MEV). Sobre este assunto, Ahmed, Lovelli e Diamond (1974), por meio da Porosimetria por Intrusão de Mercúrio (PIM), verificaram que o método de compactação pouco interferiu na estrutura dos solos argilosos compactados, 
diferentemente do exposto por Maranha das Neves (1971). Além disso, os autores observaram que a condição de umidade influencia diretamente na distribuição de poros, mostrando que os solos compactados no ramo úmido apresentam maior frequência de microporos do que aqueles compactados no ramo seco.

Delage et al. (1996) através da MEV e PIM estudaram qualitativamente e quantitativamente a microestrutura de um solo siltoso compactado. Na Figura 6 observa-se no ramo seco uma elevada frequência de poros maiores, evidenciando a presença de agregações acompanhada de uma distribuição bimodal dos poros. Na umidade ótima foram observadas agregações de menores diâmetros. Já no ramo úmido, o teor de umidade é suficiente para que as partículas de silte ocupem os vazios intra-agregados. Quanto ao formato da distribuição dos poros, Camapum de Carvalho et al. (2012) afirmaram que a mesma pode variar de bimodal a unimodal mas, que depende da energia de compactação utilizada.
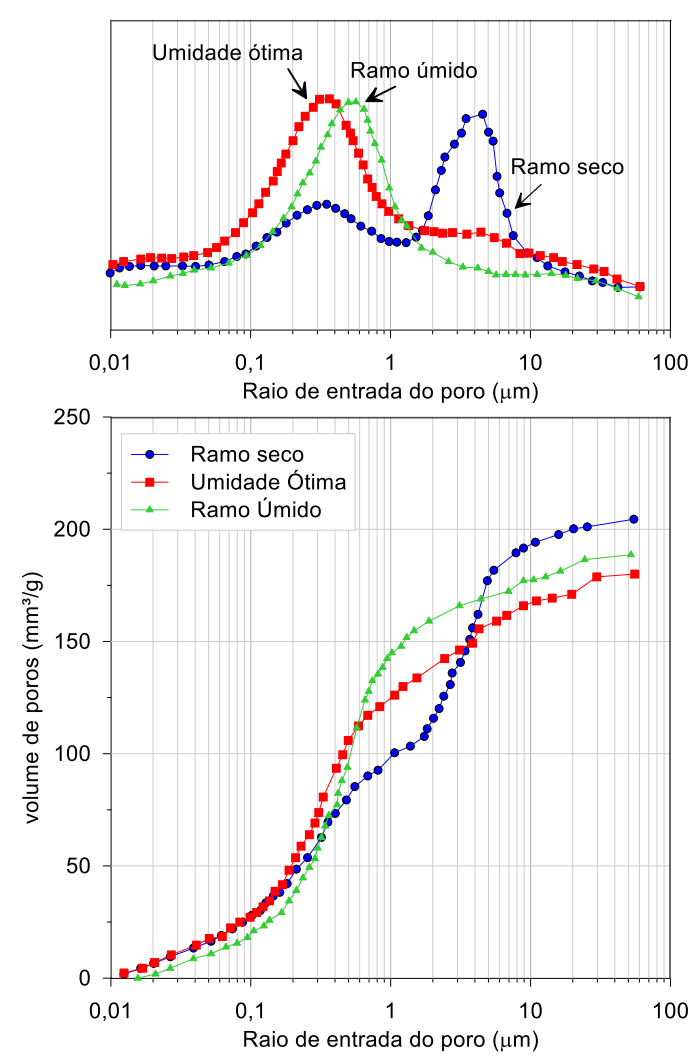

Figura 6 - Distribuição de volume de poros em função do diâmetro (Adaptada de DELAGE et al., 1996).

Oliveira (2004) estudou o efeito da compactação na estrutura de um solo residual de gnaisse compactado, a partir de três condições de moldagem (umidade ótima, ramos seco e úmido). Utilizando imagens de MEV (Figura 7) o referido autor observou que a 
estrutura na umidade ótima e ramo úmido são parecidas e que apresentam aspecto homogêneo. Já no ramo seco foram observadas maiores aglomerações de partículas, evidenciando a formação de macroporos.
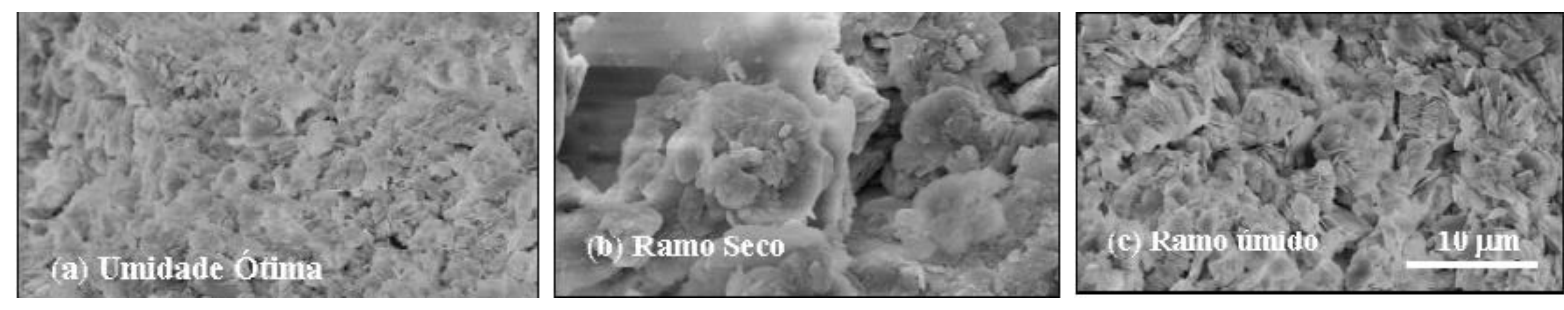

Figura 7 - Imagens de microscopia eletrônica de varredura obtidas de corpos de prova moldados na curva de compactação (x4000). (OLIVEIRA, 2004).

Segundo Mascarenha (2008), Romero e Simms (2008) e Queiroz (2015), diversas pesquisas tem sido desenvolvidas sobre a aplicação da técnica de porosimetria por intrusão de mercúrio na avaliação do desempenho hidromecânico do solo. Uma das vantagens dessa técnica consiste na sua simplicidade de execução em comparação com ensaios tradicionais. No entanto, a porosimetria por intrusão de mercúrio ainda é pouco utilizada no Brasil, devido, principalmente a baixa disponibilidade de equipamentos.

Simms e Yanfun (2005), Cardoso, Alonso e Neves (2013) e Mašín (2013) desenvolveram modelos, através da porosimetria por intrusão de mercúrio, para explicar parâmetros como: curva de retenção, condutividade hidráulica e variação volumetria, tais modelos tem aplicação direta na avaliação do comportamento hidromecânico do solo compactado.

A técnica de porosimetria por intrusão de mercúrio oferece algumas limitações, como alerta Mitchell e Soga (2005):

- Os poros devem estar totalmente secos, para isso utiliza-se o processo de congelamento evitando os efeitos da mudança de volume pós-secagem;

- Os poros inclusos e isolados não são medidos;

- Os poros acessíveis pelos poros menores serão medidos apenas quando estes forem preenchidos.

\subsubsection{Comportamento do solo compactado}

Como visto anteriormente, a condição de umidade de compactação interfere na formação da estrutura do solo e, em termos práticos, a variação do teor de umidade de compactação pode influenciar no desempenho de obras de terra. 
Como critério de projetos em barragens, pode ser necessário especificar zonas nas quais o material utilizado esteja com teores de umidade diferentes da ótima (CRUZ, 1999). Este procedimento visa tornar o solo adequado às necessidades da obra, garantindo que sejam atendidas as especificações de projeto, relacionadas a resistência, permeabilidade, deformabilidade e/ou compressibilidade.

A Figura 8 apresenta uma seção típica de uma barragem brasileira, onde é possível notar a relação da condição de umidade durante a compactação e ao longo da vida útil da barragem. Cruz (1999) observou que tanto a montante como a jusante, normalmente são compactadas camadas de solo com teor de umidade próximo ao ótimo (região A), enquanto a compactação do núcleo da barragem é realizada com maiores teores de umidade (ramo úmido), objetivando que a condutividade hidráulica nesta região seja menor.

Por conseguinte, o teor de umidade também é uma variável importante ao longo da vida útil da barragem, pois a sua estabilidade pode estar diretamente relacionada com a condição de saturação do material que a constitui. Na maioria das barragens brasileiras, a condição não saturada ocorre apenas no início do período construtivo (CRUZ, 1999). Após este período, a longo prazo, ocorre um predomínio de solos possivelmente saturados, sendo que a condição não saturada se desenvolve somente acima dos drenos horizontais em barragens não confinadas.

Cruz (1999) afirmou que a condição de saturação interfere diretamente na definição da superfície de ruptura, conforme Figura 8. A ruptura a longo prazo em solo não saturado só é possível na região $A$, ou seja, círculo 1. Outras possíveis condições de ruptura se dariam nos círculos 2 e 3 (condição possivelmente saturada). Em outras palavras, o estudo do solo em condição saturada tem sua importância para análises da estabilidade a longo prazo.

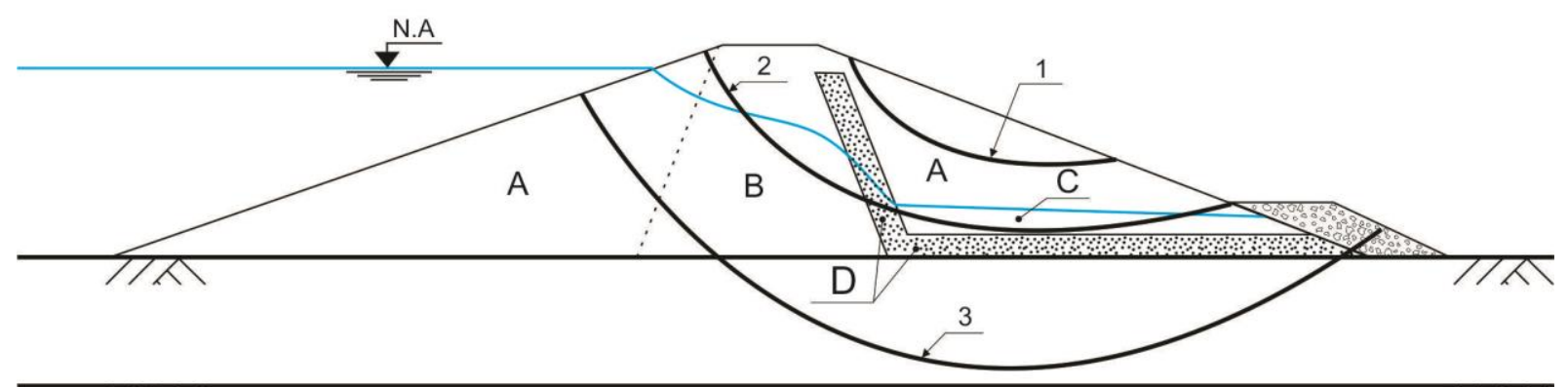

\footnotetext{
A - Montante e Jusante, compactado entre: $\mathrm{GC}=95$ - 100\% da massa especifica seca

máxima obtida pelo ensaio Proctor normal e umidade abaixo do $\mathrm{w}_{\mathrm{ot}}$

B - Pseudo núcleo, compactado entre: $\mathrm{GC}=95-100 \%$, no entanto acima do $\mathrm{w}_{\mathrm{ot}}$

C - Zona acima do dreno horizontal com material saturado por capilaridade

D - Drenos horizontais e verticais de materiais arenosos

1 - Superfície de ruptura a longo prazo em condição não saturado.

2 e 3 - Superfícies de ruptura a longo prazo.
}

Figura 8 - Perfil típico de barragens brasileiras (Adaptada de CRUZ, 1999). 
Diante das interferências apresentadas em relação ao grau de compactação e ao teor de umidade de um solo, faz-se necessário o estudo do comportamento do solo compactado em diferentes condições quanto à resistência ao cisalhamento, deformabilidade. condutividade hidraúlica e compressibilidade, a fim de gerar subsídio para uma melhor avaliação destas propriedades nas principais fases da obra.

\subsubsection{Resistência ao Cisalhamento}

O conhecimento das tensões atuantes em obras geotécnicas é preponderante na avaliação da sua vida útil. A posteriori é necessário conhecer a capacidade do aterro de suportar tais esforços sem que haja elevados deslocamentos no maciço. Assim, atribui-se à resistência ao cisalhamento do solo a propriedade de suportar estes esforços, garantindo sua estabilidade. Por sua vez, esta propriedade interfere diretamente na estabilidade de obras relacionadas a engenharia de fundações e de solos, como a estabilidade de taludes, obras de terra e capacidade de carga em sapatas e estacas (CAPUTO, 1988).

De maneira geral, a resistência ao cisalhamento está diretamente relacionada aos efeitos do atrito e da coesão do solo. A resistência ao cisalhamento advém da parcela de atrito e, dos contatos entre partículas atribuídos a atração química entre elas, o que pode gerar uma parcela de resistência ao cisalhamento, denominada como coesão real, a qual é independente da tensão normal aplicada. A resistência ao cisalhamento é o limite oferecido pelo solo a carregamentos impostos, sem que haja ruptura do material (HEAD, 1998).

Lambe e Whitman (1969) apresentaram uma interpretação física da tensão efetiva sob o ponto de vista microscópico. Os referidos autores afirmaram que a superfície de contato real corresponde a uma pequena parcela da superfície aparente de contato entre as partículas. Anterior a esta pesquisa, Terzaghi (1936), por meio do Princípio das Tensões Efetivas estabeleceu a Equação 1. Nesta equação é possível mensurar as resultantes das variações de tensões nos solos, como resistência ao cisalhamento, distorção e compressão.

$\sigma^{\prime}=\sigma-u$

Onde: $\sigma^{\prime}=$ tensão efetiva; $\sigma=$ tensão total; $u=$ pressão da água intersticial ou pressão neutra.

A resistência ao cisalhamento de um solo varia conforme o critério de ruptura adotado. Na geotecnia, o critério mais utilizado é o de Mohr-Coulomb. Neste critério a 
resistência ao cisalhamento é tratada como uma envoltória que pode ser representada por uma reta, conforme a Equação 2.

$\tau=c^{\prime}+\sigma^{\prime} \times \operatorname{tg} \phi^{\prime}$

Onde: $c^{\prime}=$ intercepto coesivo; $\phi^{\prime}=$ ângulo de atrito.

$\mathrm{Na}$ engenharia geotécnica ensaios de compressão triaxial são utilizados na obtenção dos parâmetros de resistência do solo ( $c^{\prime}$ e $\phi^{\prime}$ ), os quais estão intimamente relacionados às faixas de tensões efetivas aplicadas (MELLO, 1982). O ângulo de atrito e o intercepto coesivo são tidos como propriedades não constantes, e dependem de uma série de fatores. Gerscovich (2012) destacou algumas condições que afetam os resultados de c' e $\phi ’$

- condições de drenagem;

- trajetória de tensões (variação de $\sigma_{2}$ );

- direção do ensaio (solo anisotrópico);

- velocidade de ensaio (argilas);

- compacidade da amostra.

Ao analisar os parâmetros de resistência do solo, observa-se certo "ganho" de resistência atribuido ao efeito dos esforços empregado durante compactação, o qual tem um aumento proporcional à energia de compactação aplicada (PINTO, 1971, 2006; MELLO, 1977; ASSIS; HERNANDEZ; COLMANETTI, 2006). Alguns autores associam esse "ganho" de resistência ao que ocorre nas argilas sobreadensadas, denominando esse fenômeno como uma espécie de "pré-adensamento" (MELLO, 1977; CRUZ, 1985). No entanto, em ensaios rotineiros é difícil separar os efeitos do "pré-adensamento" daqueles oriundos do efeito da sucção, por exemplo (BARROS, 1985).

Por sua vez, a tensão de "pré-adensamento" induzida depende diretamente da capacidade de retenção da energia aplicada, pois este comportamento está intimamente relacionado à histerese de compressão e descompressão durante o ensaio de compactação (BARROS, 1985; ASSIS, HERNANDEZ; COLMANETTI, 2006).

Barros (1985) observou em solos arenosos compactados, que o valor da tensão de "pré-adensamento" varia em torno de 200 a 700 kPa para graus de compactação da ordem de 80 a 105\%. Já em solos argilosos compactados, Cruz (1963) obteve tensões de "préadensamento" que variaram de 300 a 500 kPa. Portanto, a tensão de "pré-adensamento" 
interfere nos parâmetros de resistência ao cisalhamento ( $c^{\prime}$ e $\left.\phi^{\prime}\right)$, a depender do intervalo de tensões de confinamento a que o solo é submetido.

No intuito de estudar o efeito da tensão de "pré-adensamento" nos parâmetros de resistência ao cisalhamento, Mello (1977) dividiu a envoltória de resistência em três trechos aproximadamente retilíneos (Figura 9), para que fosse possível agrupar os solos com propriedades semelhantes em cada trecho. A partir disso, tornou-se possível entender como a tensão de "pré-adensamento" interfere nos parâmetros de resistência do solo compactado. Assim, observou-se que o efeito da compactação tem maior importância para faixas de pressões inferiores a de "pré-adensamento" (ASSIS; HERNANDEZ; COLMANETTI, 2006).

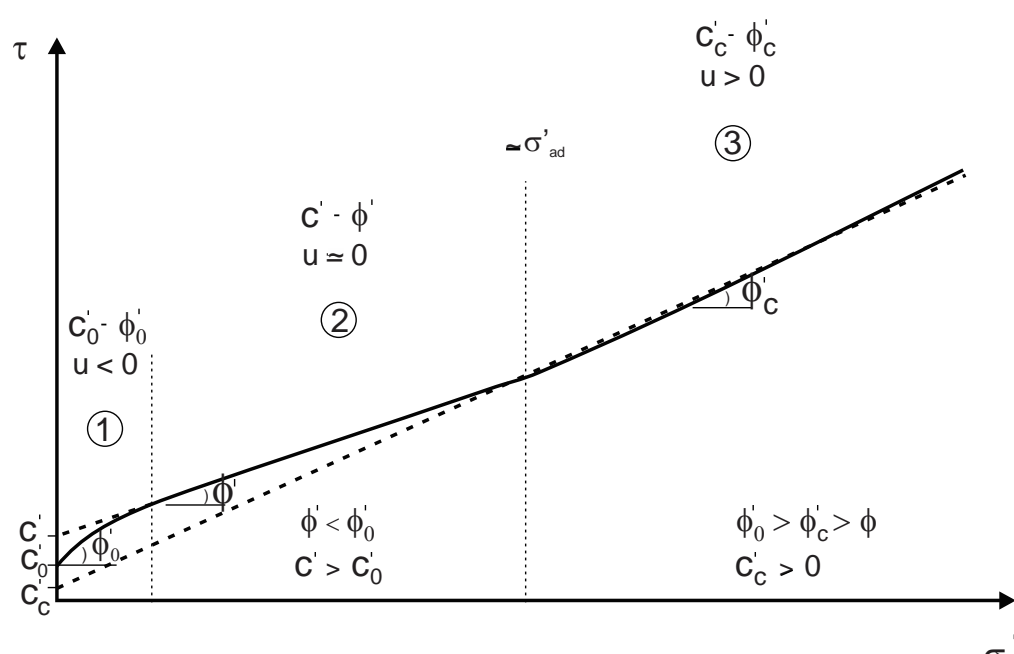

Figura 9 - Envoltória de resistência para solos compactados (Adaptada de MELLO, 1977).

Para confinantes que variam de 0 (zero) a um décimo da tensão de "préadensamento" as pressões geradas na água são negativas. No trecho intermediário ocorre aumento da resistência ao cisalhamento ainda devido ao efeito do "sobreadensamento". Nesse trecho o solo oferece maiores interceptos coesivos e menores ângulos de atrito, acompanhado de pressões positivas da água intersticial, mas que se aproximam de zero. $\mathrm{E}$ no trecho final (três) os parâmetros de resistência são intrínsecos ao solo $\left(c^{\prime}{ }_{c}\right.$ e $\left.\phi^{\prime}{ }_{c}\right)$, neste intervalo, observa-se que o solo tende a gerar pressões positivas da água intersticial.

Comumente a tensão de pré-adensamento é estimada por meio de ensaios de compressão edométrica (confinada). Entretanto, associado ao modelo apresentado por Mello (1977) (Figura 9), a análise das trajetórias das tensões efetivas em ensaios de compressão triaxial, pode indicar o comportamento do material quanto a sua razão de sobreadensamento. 
A Figura 10 ilustra a trajetórias de tensões efetivas para solos com diferentes valores de razão de sobreadensamento. Observa-se que ao gerar pressão positiva da água intersticial, o solo se encontra normalmente adensado, proveniente de sua tendência em redução de volume. Quando sujeito a um carregamento levemente inferior a tensão de préadensamento, a trajetória de tensões efetivas se desloca para a direita gerando pressões positivas na água intersticial. No entanto, quando o solo é carregado com tensões muito inferiores a tensão de pré-adensamento, geram-se pressões negativas da água intersticial devido a sua tendência em aumentar o volume.

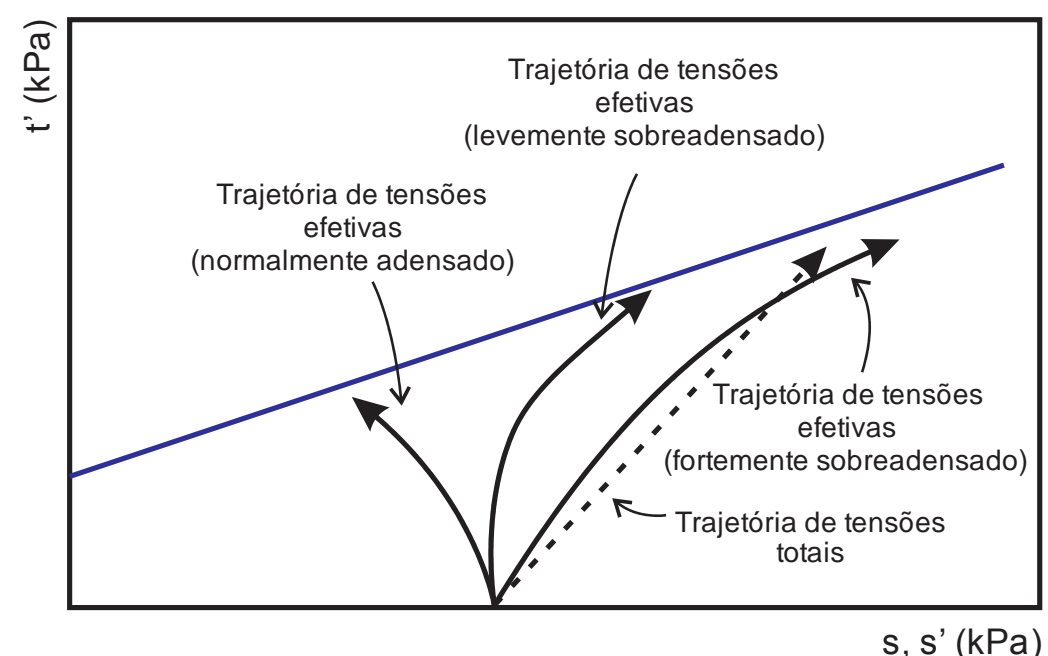

Figura 10 - Trajetória de tensões totais e efetivas para diferentes condições de pré-adensamento. (Adaptada de BREAUD, 2013).

Cruz (1963) alertou que o efeito da tensão de "pré-adensamento" em solos compactados deve ser tratado com certas ressalvas, visto que a formação da estrutura dos solos compactados é diferente das argilas pré-adensadas em campo, portanto, seus efeitos no desempenho mecânico e hidráulicos não devem ser generalizados.

A respeito do efeito da tensão de "pré-adensamento" em solos compactados, Assis, Hernandez e Colmanetti (2006) destacaram:

- Para faixas de tensões inferiores a de "pré-adensamento", o efeito da compactação tem maior aporte no comportamento geotécnico do solo. Por outro lado, para maciços submetidos a tensões maiores que a de "préadensamento", praticamente não ocorre influência dos parâmetros de compactação nas propriedades geotécnicas de interesse, sendo dependente apenas do tipo de solo; 
- A capacidade do solo de reter a energia e a expansão durante a compactação são os fatores que interferem diretamente no "préadensamento" de solos compactados.

Barros (1985) listou as principais interferências na resistência do solo compactado, sendo possível observar três condições básicas:

- o teor da umidade durante a compactação, visto a sua interferência na formação da estrutura;

- o efeito da tensão de "pré-adensamento" nos parâmetros de resistência ao cisalhamento;

- a difícil saturação dos corpos de prova, inserindo-os numa condição parcialmente saturada.

Após a escolha da faixa de tensões de confinamento de interesse, torna-se importante estudar o efeito da variação dos índices físico nos parâmetros de interesse do projeto. Uma visão geral da influência dos parâmetros de compactação $\left(\rho_{d}\right.$ e w) em determinadas características do solo, pode ser obtida através de gráficos de igual valor dessa propriedade para que seja possível a interpolação dos valores e observação de sua tendência típica (PINTO, 2006).

Em seus estudos, utilizando um silte arenoso micáceo de uma área de empréstimo do dique de Paraitinga/SP, Pinto $(1971 ; 2006)$ percebeu que a resistência efetiva (em termos de $c^{\prime}$ ) depende basicamente da massa específica seca, visto a pouca dependência do teor de umidade de compactação (Figura 11). Isso se deve ao efeito do "préadensamento", tanto maior quanto for a energia de compactação empregada. Esta conclusão é importante, pois caso a preocupação do projetista de uma barragem seja, por exemplo, o rebaixamento rápido do lençol freático, todas as atenções devem ser voltadas para o controle do grau de compactação do aterro (PINTO, 2006). 


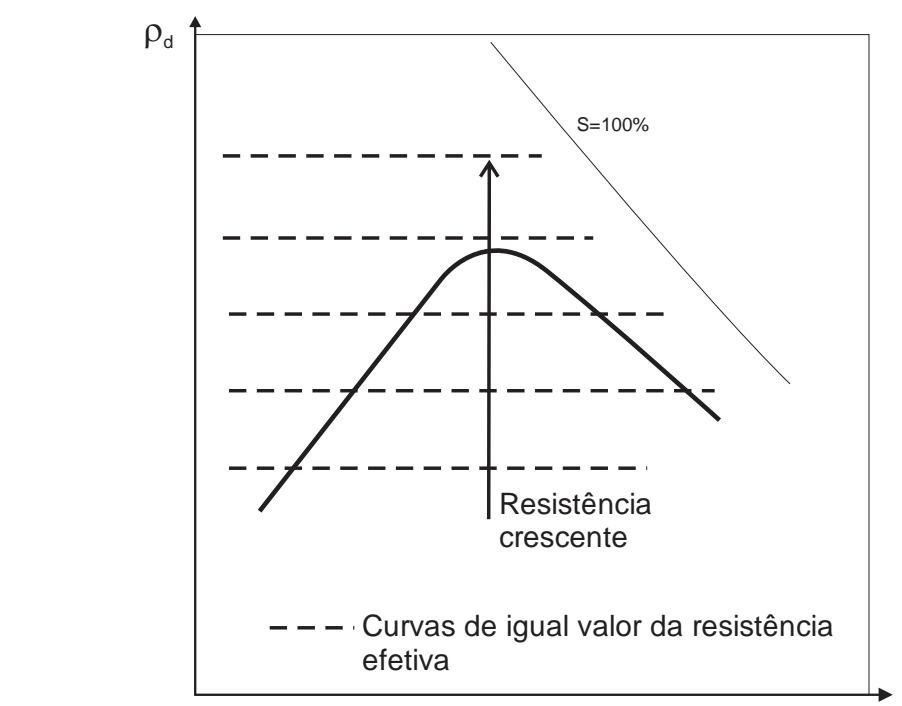

Figura 11 - Tendência de intercepto coesivo efetivo em termos de tensões efetivas para ensaios do tipo CU. (PINTO, 1971; 2006).

\subsubsection{Deformabilidade}

Em obras geotécnicas, pode-se ter uma previsão das suas deformações através do conhecimento profundo das características de deformabilidade do material (SILVA, 1996). Por mais que o solo não possua características de um material elástico, para uma grande faixa de deformações há a necessidade de adotar hipóteses simplificadoras do comportamento tensão-deformação no intuito de propor soluções rápidas e eficazes (PAIVA, 1996).

$\mathrm{Na}$ construção de aterros o estudo da deformabilidade é relevante tanto para critério de projeto como na identificação da própria variabilidade do maciço. A análise do desempenho do solo frente a pequenas deformações é frequentemente considerada como um indicativo do seu comportamento geomecânico (HEITOR et al., 2013).

A fim de representar a faixa de deformações onde solo é tomado como elástico, muitas vezes são utilizadas algumas simplificações advindas da teoria da elasticidade. $O$ módulo de deformabilidade longitudinal, ou módulo de Young $(E)$ é comumente obtido pela função não linear da relação tensão-deformação (Figura 12a). Por sua vez, este módulo é variável e depende do nível de deformação a ser considerado, e pode ser calculado como módulo secante $\left(E_{\mathrm{sec}}\right)$ e/ou tangente $\left(E_{\mathrm{tan}}\right)$. Na Figura 12b é possível notar que para muito pequenas deformações, a deformabilidade é aproximadamente constante $\left(E_{0}\right)$ até o limiar do trecho elástico $\left(\varepsilon_{0}\right)$ e, nesse nível de deformações os módulos de deformabilidade são iguais $\left(E_{0}=E_{\mathrm{sec}}=E_{\mathrm{tan}}\right)$. Para deformações maiores que $\varepsilon_{0}$ e menores que $0,1 \%$ a rigidez diminui rapidamente. Já para deformações maiores que $0,1 \%$ o solo se encontra no intervalo de 
grandes deformações. Além disso, é possível notar que $E_{\text {tan }}$ tende a zero para valores de deformação próximos a diferença das tensões principais máximas.

(a)

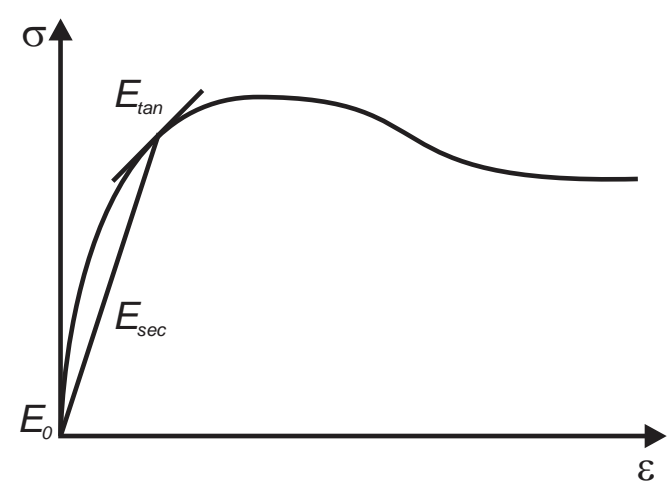

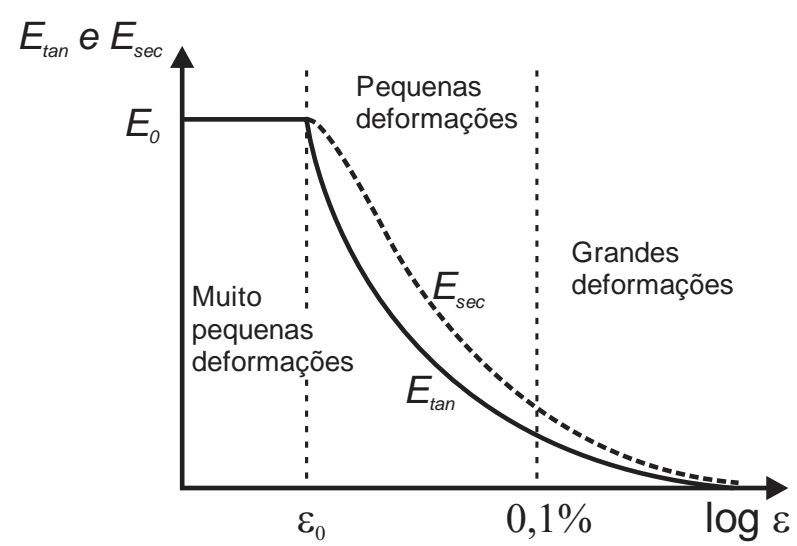

$\varepsilon_{0}$ (b)

Figura 12 - Comportamento não linear da deformabilidade (a) tensãodeformação e (b) módulo de deformabilidade (Adaptada de ATKINSON, 2000).

Da teoria da elasticidade é possível relacionar o Módulo de Young $(E)$ e o Módulo de Cisalhamento ou Módulo de Rigidez Elástico Transversal $(G)$, caso se conheça o coeficiente de Poisson ( $v$ ) do material, de acordo com a Equação 3.

$$
G=\frac{E}{2 \times(1+v)}
$$

Pinto (2006) observou que módulo de elasticidade secante $\left(E_{\mathrm{sec}}\right)$ decresce com o aumento do teor de umidade de compactação, por outro lado, no ramo seco, esse efeito é mais pronunciado pela variação do grau de compactação do que por variações na condição de umidade do solo. As variações de módulo de elasticidade estão associadas a mudanças estruturas causadas no solo.

Além dos ensaios de laboratório, a deformabilidade do solo pode ser determinada através de ensaios de campo do tipo Crosshole, Downhole, Uphole, entre outros. Barros e Hachichi (1998) discutiram que no Brasil a técnica sísmica mais utilizada é o Crosshole, uma vez que apresenta resultados mais confiáveis. Diversos trabalhos brasileiros se propuseram a estudar as peculiaridades do comportamento da deformabilidade dos solos tropicais, entre os quais é possível destacar: Giacheti (1991), Barros, Giacheti e Martins (1991), Barros (1997) e Rocha (2013). 
$\mathrm{Na}$ Tabela 1 foram listados os principais ensaios utilizados na análise das deformações e seus respectivos intervalos. Basicamente esses métodos têm como finalidade aplicação de ondas do tipo $S$ para avaliar o módulo de cisalhamento $\left(G_{\max }\right)$, ou a razão de amortecimento interno $(D)$ através de ensaios em colunas ressonantes. Outra vertente é a utilização de ensaios sísmicos em laboratório. Os ensaios de laboratório possuem algumas vantagens, como por exemplo, o controle da sucção e tensão de confinamento nas amostras (GEORGETTI, 2014). Além disso, pode ser necessário o estudo da deformabilidade do solo frente a diferentes condições de umidade e massa específica seca.

Tabela 1 - Ensaios de laboratório mais utilizados para determinação do módulo de cisalhamento e da razão de amortecimento dos solos (BARROS; HACHICH, 1998)

\begin{tabular}{|c|c|c|}
\hline Ensaio & Princípio da técnica & $\begin{array}{l}\text { Faixas de deformação para que } \\
G_{\max } \text { e } D \text { possam ser medidos } \\
\text { (\%) }\end{array}$ \\
\hline Coluna Ressonante & Determinação da velocidade da & $10^{-4}$ a $10^{-2}$ \\
\hline Bender elements* & onda de cisalhamento $V_{s}$ & $10^{-4}$ \\
\hline $\begin{array}{c}\text { Cisalhamento simples cíclico } \\
\text { Triaxial cíclico } \\
\text { Torcional cíclico }\end{array}$ & $\begin{array}{c}\text { Determinação da curva tensão- } \\
\text { deformação } \\
\text { (lançada de histerese) }\end{array}$ & $10^{-2}$ a 1 \\
\hline $\begin{array}{l}\text { Coluna ressonante e torcional } \\
\text { cíclico combinados }\end{array}$ & $\begin{array}{l}\text { Determinação de } V_{s} \text { (coluna } \\
\text { ressonante) (torcional cíclico) }\end{array}$ & $10^{-4}$ a 1 \\
\hline
\end{tabular}

*Neste ensaio não é possível determinar a razão de amortecimento.

\section{Ensaios com bender elements}

Há mais de três décadas realiza-se em laboratório a determinação direta da velocidade de propagação da onda $(S$ e $P$ ) a partir do registro do tempo necessário para percorrer certa distância de um corpo de prova (BARROS; $\mathrm{HACHICH,} \mathrm{1998).} \mathrm{Desenvolvido}$ por Dyvik e Madshus (1985), esta técnica é denominada de bender elements e tem a função de gerar ondas $S$ com a possibilidade de inversão de polaridade, prática comum nos ensaios in situ, o que contribui para qualidade dos resultados obtidos (BARROS; HACHICH, 1998).

Os bender elementes são placas retangulares piezo-cerâmicas que quando excitadas eletricamente são fletidas transformando pulsos elétricos em deformação mecânica (Figura 13). Em laboratório esse equipamento pode ser acoplado a ensaios como: triaxial, cisalhamento direto e adensamento. 


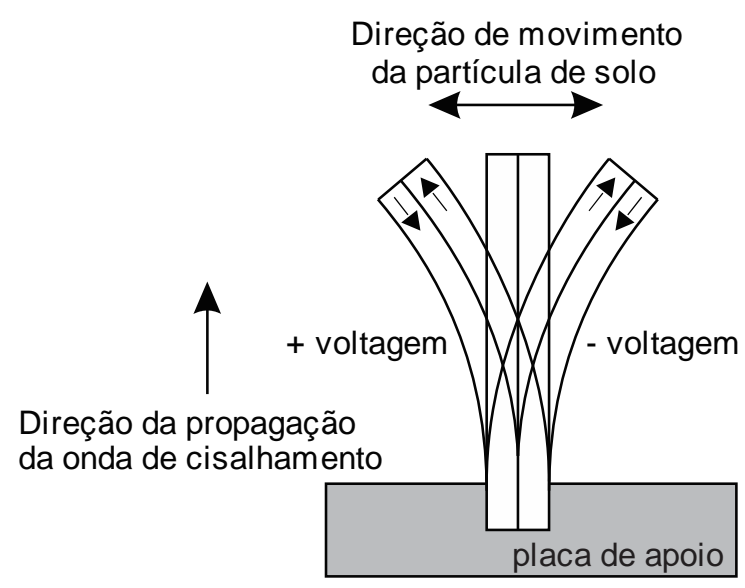

Figura 13 - Esquema de propagação de onda cisalhante no corpo de prova (Adaptada de BRIAUD, 2013).

Os bender elements são dispostos nas extremidades do corpo de prova de tal forma que o pulso gerado pela primeira placa percorre o corpo de prova e, em função do tempo gasto no percurso, seja calculado a velocidade de cisalhamento $\left(V_{\mathrm{s}}\right)$. Nessas condições pode-se considerar que o material encontra-se no regime elástico, sendo possível calcular o módulo de cisalhamento máximo $\left(G_{\max }\right)$ por meio da Equação 4.

$G_{\max }=\rho V_{s}^{2}=\rho\left(\frac{L_{t t}}{t}\right)^{2}$

Onde: $\rho=$ massa específica do solo; $V_{\mathrm{s}}=$ velocidade da onda de cisalhamento; $L_{t t}=$ distância percorrida pelo pulso de cisalhamento formado pelas extremidades dos bender elements.

A determinação do tempo de chegada da onda nos ensaios com bender elements é ainda muito discutida. Tanto o método do domínio do tempo como da frequência são utilizados para determinar o tempo $t$, decorrido entre a emissão da primeira onda e a maior deflexão do sinal recebido.

A fim de minimizar as interferências do ensaio, pode ser necessária a escolha de altas frequências de excitação do pulso emitido. A partir da relação entre a distância percorrida pela onda $\left(L_{t t}\right)$ e comprimento de onda $(\lambda)$ é possível diminuir as interferências do ensaio. A estimativa do comprimento da onda pode ser realizada mediante a relação entre a velocidade e a frequência da onda emitida. Brignoli, Gotti e Stokoe (1996) e Arulnathan, Boulanger e Riemer (1998) observaram que para relação de $L_{t t} / \lambda$ maior que dois as interferências são insignificantes. Entretanto, Georgetti (2014) observou que apenas para relações maiores que 3 as interferências foram reduzidas. 
Heitor, Indraratna e Rujikiatkamjorn (2013) investigaram o efeito do teor de umidade de compactação em diferentes energias na deformabilidade $\left(G_{\max }\right.$ ou $\left.G_{0}\right)$ de uma areia siltosa. Estes autores observaram que o maior valor de $G_{0}$ não corresponde àquele obtido no corpo de prova moldado na umidade ótima. Este comportamento pode ser justificado pelo efeito combinado da massa específica seca, sucção e estrutura. Além disso, os autores comentam que no ramo seco o solo tende a se tornar mais rígido até certo ponto de decréscimo do teor de umidade, este efeito é proveniente da ação da sucção acompanhada de uma estrutura com maior presença de agregações (Delage et al., 1996). Para teores de umidade ainda menores, a redução da massa específica é suficiente para que $G_{0}$ decresça (Figura 14).

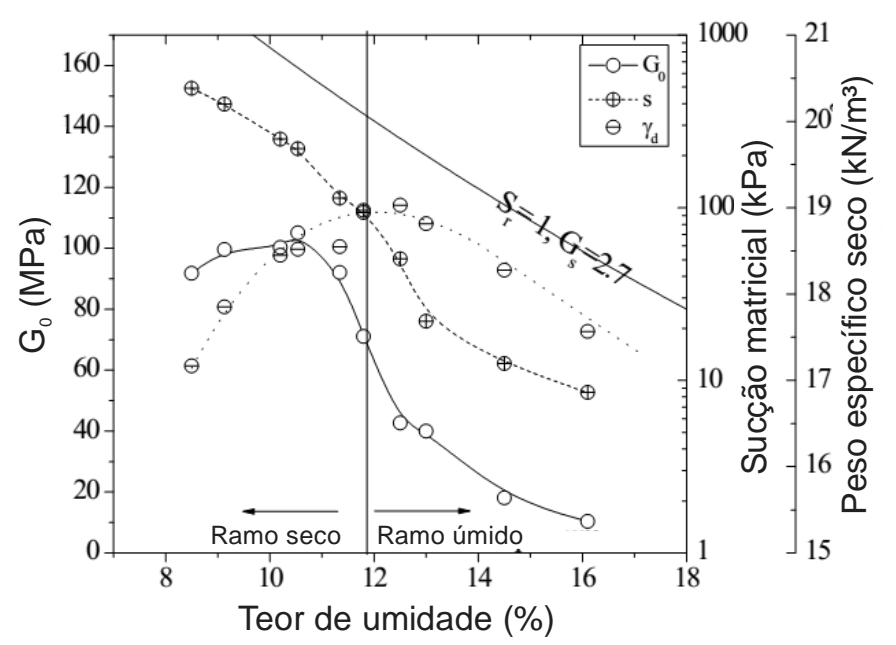

Figura 14 - $G_{0}$, sucção matricial e peso específico seco para os corpos de prova compactados em diferentes teores de umidade para a mesma energia (HEITOR; INDRARATNA; RUJIKIATKAMJORN, 2013).

\subsubsection{Condutividade Hidráulica}

A condutividade hidráulica pode ser entendida como o deslocamento da água submetida a certa diferença de potencial. O estudo da condutividade hidráulica é indispensável para qualquer caso em que ocorra o movimento de água pelos poros do solo. Em barragens, o controle de fluxo no maciço é fator determinante na segurança da obra (CRUZ, 1996). Da mesma forma em obras ambientais é possível destacar a importância de se avaliar as características hidráulicas de solos compactados. Sendo assim, a escolha dos materiais empregados na construção de barreiras impermeáveis para aterros sanitários, devem atender a condutividade hidráulica recomendada em projeto (MITCHELL; HOOPER; CAMPANELLA, 1965; BENSON; DANIEL, 1990; BENSON; TRAST, 1995; LUKIANTCHUKI, 2007; SILVA, 2015). 
Darcy (1856) realizou um experimento no intuito de observar quais fatores geométricos interfeririam no fluxo da água, em um filtro de areia limpa. A partir desse estudo, Darcy demonstrou que a velocidade de um fluído (Equação 5) é diretamente proporcional ao gradiente hidráulico $(i)$, cuja constante de proporcionalidade é denominada de condutividade hidráulica $(k)$. O gradiente hidráulico e o fluxo podem ser expressos por meio das Equações 6 e 7, respectivamente.

$v=k \times i$

$i=\frac{\Delta h}{L}$

$q=k \times i \times A$

Onde: $v=$ velocidade do fluido; $k=$ condutividade hidráulica; $i=$ gradiente hidráulico; $\Delta h=$ perda de carga do fluido em um trecho de comprimento $L ; q=$ vazão; $A$ = área do permeâmetro.

Vários autores contribuíram para o entendimento do comportamento hidráulico de solos compactados, dos quais é possível destacar: Michaels e Lin (1954); Lambe (1958); Mitchell Hooper e Campanella (1965); Bhasin (1975); Garcia-Bengochea, Altschaeffl e Lovell (1979); Olson e Daniel (1981); Witt e Brauns (1983); Boynton e Daniel (1985); Daniel e Benson (1990); Benson e Trast (1995); Umar, Elinwa e Matwal (2015). Desse modo, esses autores listam os principais fatores que interferem na condutividade hidráulica de solos compactados, dos quais destacam-se: teor de umidade, grau de saturação, método e energia de compactação escolhida, gradiente hidráulico, distribuição do tamanho das partículas, índices de vazios, método de ensaio, tempo de espera anterior ao início do ensaio e fissuramento.

É comum associar maiores valores de condutividade hidráulica a solos mais porosos, no entanto, Cruz (1995) alertou que as dimensões, formato e a distribuição dos poros afetam diretamente a condutividade hidráulica. $O$ referido autor retratou a correlação da curva de distribuição granulométrica com a condutividade hidráulica que só foi possível no caso das areias limpas.

Michell, Hooper e Campanella (1965) avaliaram o efeito da energia de compactação na condutividade hidráulica de argilas compactadas. Neste estudo, os autores observaram que a condutividade hidráulica é sensível às variações de teor de umidade e aos esforços de compactação. Com o aumento do teor de umidade ocorre uma redução da condutividade 
hidráulica, a ponto de que os menores valores surgem nas amostras compactadas no ramo úmido da curva de compactação. O aumento dos esforços de compactação também causa decréscimo da condutividade hidráulica devido, principalmente, ao aumento da orientação das partículas (LAMBE; WHITMAN, 1969). Para teores de umidade próximos ao ótimo a redução da condutividade hidráulica foi mais acentuada. Na Figura 15 é possível observar a variação da condutividade hidráulica em função do acréscimo tanto do teor de umidade como dos esforços empregados durante a compactação.

Dessa forma, para justificar menores valores de condutividade hidráulica no ramo úmido, pode-se recorrer à teoria do efeito da compactação na estrutura de solos finos, proposta por Lambe (1962). O referido autor postulou que o solo compactado no ramo seco apresenta estrutura do tipo floculada, com maior presença de agregações, e consequentemente maior quantidade de macroporos, facilitando assim a percolação da água. Para amostras compactadas com teores de umidade maiores que a umidade ótima (ramo úmido) as agregações existentes foram desfeitas, desenvolvendo assim estrutura do tipo dispersa, dificultando a passagem da água, e por sua vez, induzindo a percolação pelos microporos.
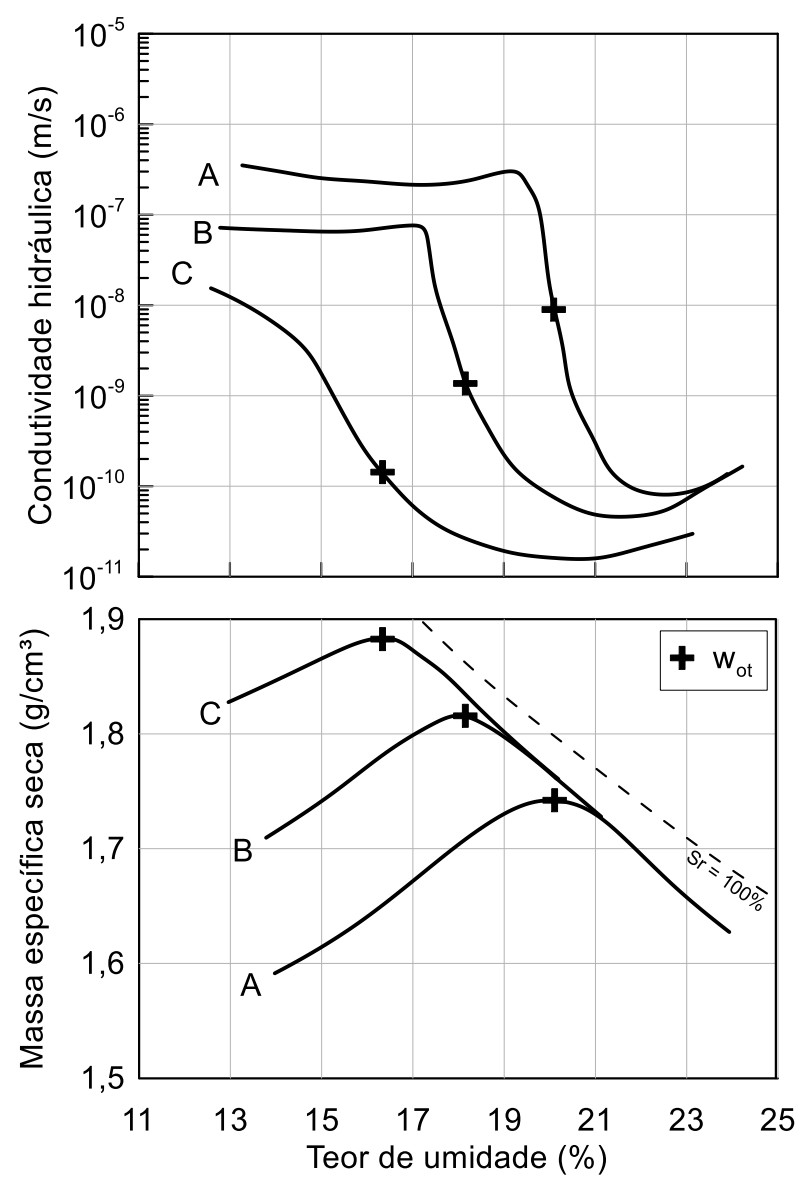

Figura 15 - Variação da condutividade hidráulica em solos compactados com diferentes energias. (Adaptada de MITCHELL; HOOPER; CAMPANELLA, 1965). 


\subsubsection{Compressibilidade}

A compressibilidade é a propriedade do solo que está relacionada com a deformabilidade perante a um nível de carregamento, provocando no solo esforços essencialmente de compressão, sem que as deformações horizontais sejam permitidas. A construção de aterros rodoviários, taludes acentuados, fundações e barragens de terra provocam esforços dessa natureza no solo (PINTO, 2006).

Quanto maior o grau de compactação, e menor for o teor de umidade, menor será a compressibilidade dos solos compactados. Esse resultado é atrelado à ação simultânea da estrutura e da sucção do material (QUEIROZ, 2015). Para estudar a relação entre a compressibilidade e a estrutura de solos compactados, Lambe (1958) realizou ensaios edométricos com duas amostras de um solo argiloso compactado, uma delas com teor de umidade localizado no ramo seco e outra no ramo úmido da curva de compactação. De maneira geral, pode-se observar na Figura 16 que as amostras compactadas no ramo úmido são mais compressíveis que aquelas compactadas no ramo seco. Na Figura 16a observa-se que baixas tensões aplicadas não são suficientes para interferir na estrutura dos solos, por outro lado, é retratado na Figura 16b que elevados níveis de tensões aplicadas podem ser suficientes para tornar a estruturas do tipo floculadas (ramo seco) em dispersas (ramo úmido).

(a)

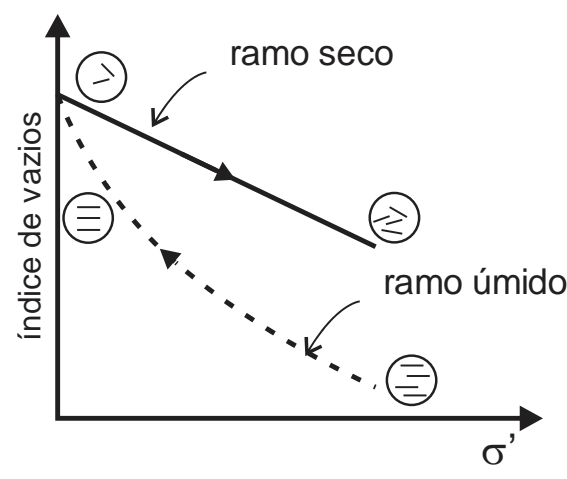

(b)

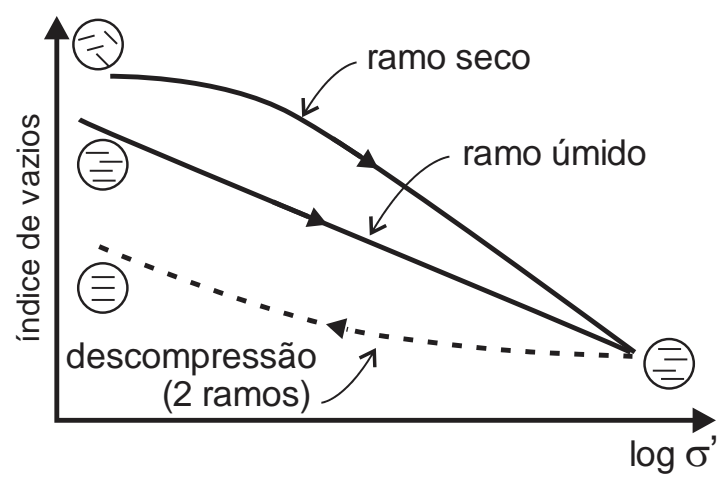

Figura 16 - Efeito do ensaio de compressão confinada na estrutura: (a) baixas tensões aplicada; (b) altas tensões aplicadas (Adaptada de LAMBE, 1958).

Pinto $(1971,2006)$ realizou uma pesquisa com amostras de um solo siltoso compactado, submetidas a ensaios oedométricos em condições inundadas (Figura 17). Estas amostras apresentaram compressibilidade como função praticamente da massa específica seca. Além disso, observou-se que as amostras compactadas com GC $=95 \%$ 
refletiram a módulo de compressão confinada $(D)$ da ordem de $70 \%$ menores que quando comparadas as amostras com $\mathrm{GC}=100 \%$.

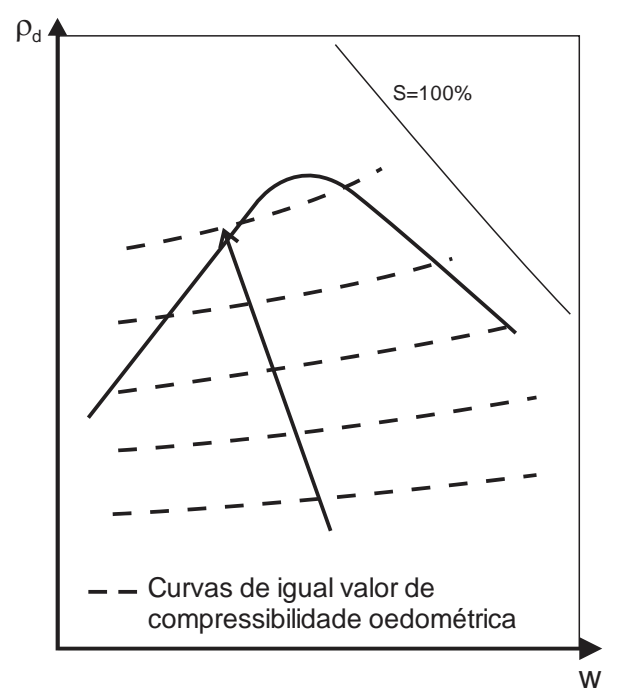

Figura 17 - Tendência de variação da compressibilidade (PINTO, 2006).

\subsection{Anisotropia}

De uma maneira geral, a anisotropia do solo está associada a heterogeneidade de sua estrutura, uma vez que alguns parâmetros de interesse se diferenciam em função da direção analisada. A formação de estruturas anisotrópicas está relacionada a diversos fatores, como: deposição horizontal das partículas, consolidação anisotrópica e compactação de aterros (MITCHELL; SOGA, 2005).

A anisotropia ocorre de dois modos distintos: inerente ou induzida. A anistropia inerente está associada ao comportamento intrínseco do material, portanto é totalmente independente das deformações aplicadas, enquanto a anisotropia induzida está relacionada a uma característica física atribuída a algum nível de deformação plástica imposta (CASAGRANDE; CARILLO, 1944).

As características intrínsecas do solo se relacionam a anisotropia do tipo inerente que, por sua vez, é sensível a formação de sua estrutura, por exemplo, no caso do alinhamento das partículas durante o processo de sedimentação (SIVAKUGAN; CHAMEAU; HOLTZ, 1984). As partículas são depositadas ao longo do plano de aplicação da tensão principal maior, desse modo o arranjo formado pode ser diferente a depender da orientação de análise. Além do processo de sedimentação de partículas, a compactação também gera anisotropia inerente (HOQUE; TATSUOKA, 1998; KONGSUKPRASERT; SANO; TATSUOKA, 2007). 
A anisotropia induzida resulta das modificações de natureza plástica causada por deformações advindas de algum nível de carregamento. Quando um solo granular é submetido a algum processo de carregamento, as deformações de natureza plástica provocam um rearranjo das partículas, propiciando a destruição de antigos contatos e o aparecimento de novos (ODA, 1993).

Para solos arenosos, Mitchell e Soga (2005) retrataram a influência da anisotropia a partir de alguns parâmetros importantes dentro da geotecnia, dentre os quais são possíveis destacar que:

- o módulo de deformabilidade e a resistência são maiores nos planos perpendiculares $\left(\theta=90^{\circ}\right)$ aos preferenciais de orientação das partículas ( $\theta=$ $\left.0^{\circ}\right)$;

- a magnitude da anisotropia depende do achatamento e alongamento das partículas;

- o módulo de elasticidade pode apresentar-se até 3 vezes maior numa direção do que em outra;

- grãos alongados, em solos arenosos, tendem a pronunciar maiores anisotropias do que em areias de grãos arredondados.

Conforme visto, a variação do teor de umidade e dos esforços empregados durante a compactação pode causar a orientação das partículas e dos poros presentes no solo e, pode contribuir para o surgimento de uma estrutura anisotrópica. Normalmente, recorre-se a ensaios corriqueiros na mecânica dos solos para quantificar a anisotropia inerente ao processo de compactação.

\subsubsection{Resistência ao cisalhamento}

A resistência de argilas sedimentares pode apresentar anisotropia ao longo do plano de ruptura, desse modo, deve-se avaliar a influência da orientação das amostras na obtenção dos parâmetros de resistência ao cisalhamento (DUNCAN; SEED, 1966; ABRAMSON, 2002; BROMHEAD, 2006). Esta observação pode ser estendida ao estudo de aterros compactados em camadas porque, neste caso, a rotação dos planos principais também pode desenvolver anisotropia ao longo do plano de ruptura (HAM et al., 2012).

O ensaio de compressão triaxial pode ser utilizado no estudo da anisotropia frente a resistência ao cisalhamento. Entretanto, deve-se adequar o ensaio a uma metologia que 
simule as condições anisotropícas de campo. Abramson (2002) lista os três principais métodos empregados, a saber:

- Ensaio de compressão triaxial com incrementos axiais de cargas a partir de amostras compactadas em caixas e posteriormente talhadas na direção vertical $\left(\theta=90^{\circ}\right)$ e horizontal $\left(\theta=0^{\circ}\right)$;

- Ensaio em caixas que permitem o cisalhamento das amostras em diferentes planos;

- Obtenção da resistência não drenada em campo através do vane test.

Diversos estudos foram conduzidos na avaliação da anisotropia em depósitos de argilas e areias saturadas, dos quais destacam-se: Duncan e Seed (1966), Nakase e Kamei (1983), Sivakugan, Chameau e Holtz (1984), Mikasa, Takada e Ohshima (1987), Cabral (2005). Além dessa linha de pesquisa, diversos autores se propuseram a estudar o efeito da anisotropia inerente promovida pelo ensaio de compactação a partir de ensaios de compressão triaxial ou cisalhamento direto, dos quais destacam-se: Kim (1996) Silva (1996), Kongsukprasert, Sano e Tatsuoka (2007), Rowshanzamir e Askari (2010), Crispim (2010), Ham et al. (2012) e Da Fonseca, Rios e Amaral (2013). Por mais que na literatura a anisotropia seja mais pronunciada em depósitos de argilas, Silva (1996) observou que um solo arenoso compactado pode apresentar grau de anisotropia maior do que em argila adensada em laboratório.

A orientação do plano de ruptura frente as tensões principais atuantes no maciço pode ser significativo no cálculo da estabilidade de taludes anisotrópicos. Em linhas gerais, pode-se afirmar que a resistência ao cisalhamento é fortemente influenciada pelo ângulo formado entre o plano de compactação e a orientação da sua amostragem, ângulo $\theta$ (HAM et al., 2012). Na Figura 18, Abramson (2002), mostra três possíveis condições de orientação dos planos principais ao longo de uma superfície de ruptura.

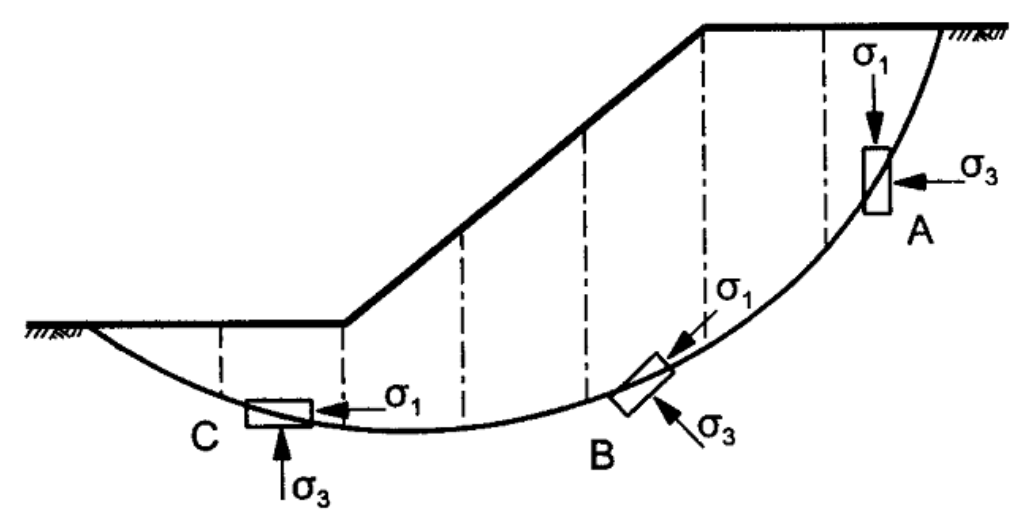

Figura 18 - Direção da anisotropia de resistência (ABRAMSON, 2002). 
Duncan e Seed (1996) observaram em depósitos de argila sedimentar que a resistência não drenada para o elemento $C\left(\theta=0^{\circ}\right)$ pode ser $75 \%$ menor que a resistência para o elemento $A\left(\theta=90^{\circ}\right)$. Em termos de tensões efetivas, a resistência obtida para 0 elemento A e C é da ordem de $\phi^{\prime}=38^{\circ}$ e $\phi^{\prime}=35^{\circ}$, respectivamente, ou seja, maior na direção vertical do que na direção horizontal.

Sivakugan, Chameau e Holtz (1993) e Michell e Soga (2005) avaliaram o efeito da anisotropia na resistência ao cisalhamento dos solos e, concluíram que em ensaios nas condições não drenadas a resistência em termos de tensões efetivas praticamente não é afetada pela direção de ensaio, por mais que sejam observadas diferenças significativas nos parâmetros de resistência em termos de tensões totais (Figura 19). Portanto, nessas condições a pressão da água intersticial, ou pressão neutra, assume valores diferentes, dependendo da direção de talhagem.

Sivakugan, Chameau e Holtz (1993) obtiveram em seus resultados maiores valores de pressão da água intersticial nos corpos de prova talhados na direção horizontal, no entanto, como observa-se no esquema proposto por Michell e Soga (2005), estes valores podem ser maiores nas amostras talhadas na direção vertical (condição 1) (Figura 19).

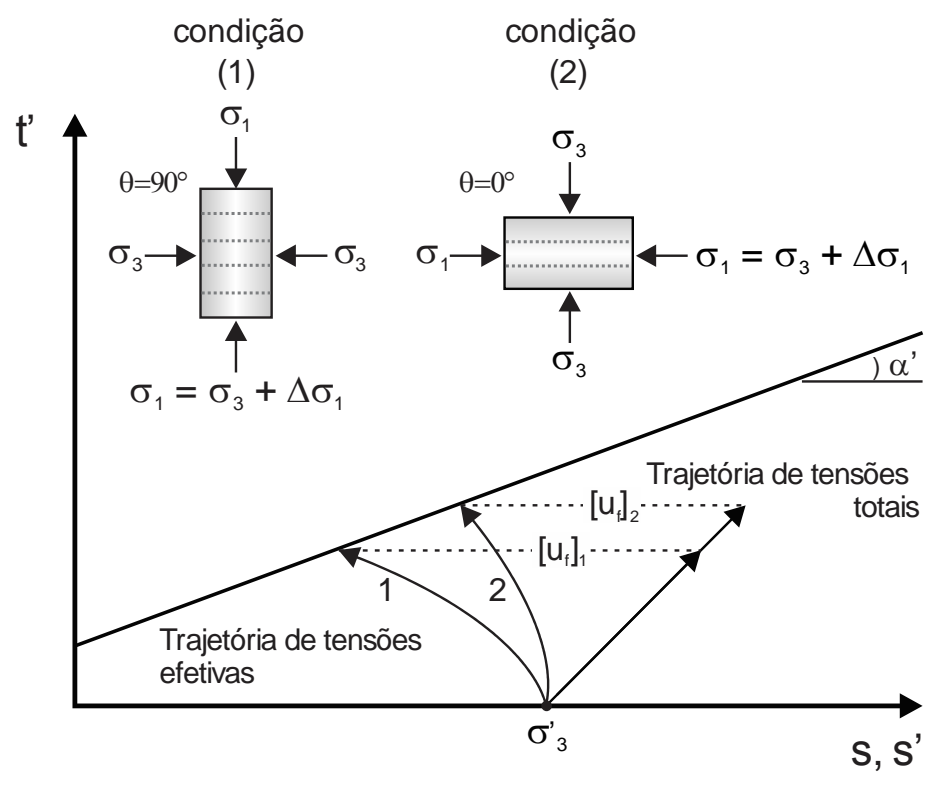

Figura 19 - Trajetória de tensões totais e efetivas em ensaio triaxial para corpos de prova orientados em diferentes direções (Adaptada de MITCHELL; SOGA, 2005).

A variação de pressão da água intersticial durante carregamentos não drenados pode ser relacionada com a tendência na variação volumétrica em ensaios onde a drenagem na fase de ruptura é permitida. Kongsukprasert, Sano e Tatsuoka. (2007) apontaram que quando submetidos a drenagem na fase de ruptura, os corpos de prova talhados na direção horizontal apresentaram maiores variações de volume do que aqueles 
talhados verticalmente. Os referidos autores justificam este fato a maior facilidade das partículas em se orientarem, principalmente ao longo da região perpendicular à aplicação dos esforços oriundos do processo de compactação (interface entre camadas). A facilidade das partículas em se orientarem ao longo desse plano pode contribuir para a separação lateral das partículas quando submetidas a incrementos de deformações (Figura 20).

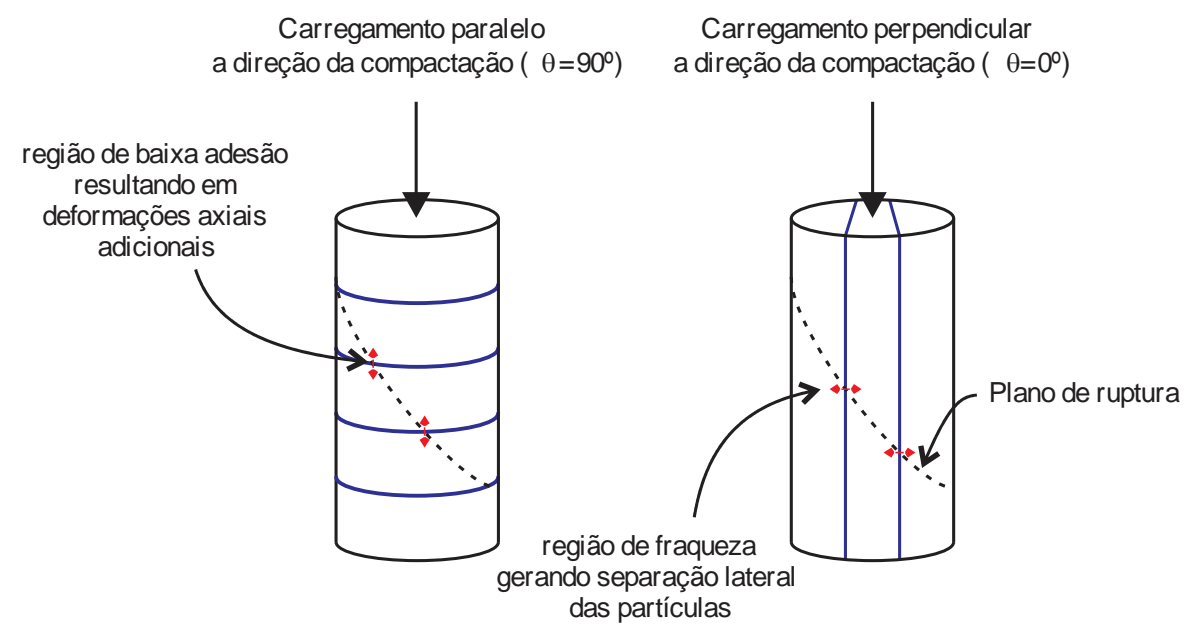

Figura 20 - Comportamento típico de solo compactado e talhados na direção vertical e horizontal (Adaptada de KONGSUKPRASERT; SANO; TATSUOKA, 2007)

A utilização de análises estatísticas pode fornecer subsídios à interpretação das variáveis que mais interferem na resistência de solos compactados. Crispim (2010) abordou o efeito dos métodos de compactação frente a resistência mecânica de 5 solos residuais típicos do estado de Minas Gerais, Brasil. Mediante testes de hipóteses, o autor observou que o tipo de solo pouco influencia na anisotropia. Por outro lado, o método de compactação empregado pode interferir significativamente nos parâmetros de resistência ao cisalhamento das amostras (Tabela 2).

Tabela 2 - Influência do método de compactação na anisotropia de resistência dos solos (CRISPIM, 2010)

\begin{tabular}{ccc}
\hline & Correlação fraca com o tipo de solo \\
Quando ocorreu & Compactação estática & Afetou c' e $\phi^{\prime}$ \\
& Compactação dinâmica & Afetou apenas c' \\
\hline
\end{tabular}

Rowshanzamir e Askari (2010) estudaram o efeito da orientação dos corpos de prova de um solo arenoso compactado, submetidos a ensaios de compressão simples. Em linhas gerais, observou-se que tanto o aumento do teor de umidade de compactação como o aumento da massa específica seca conferiu às amostras graus de anisotropia da ordem de 
1,04 a 1,23 (Figura 21a,b). Na Figura 21c é possível notar o efeito da saturação prévia das amostras antes da realização dos ensaios de compressão simples. A investigação do efeito da saturação na massa específica seca indicou que a razão de anisotropia tende a aumentar nas amostras ensaiadas antes da saturação.

(a)

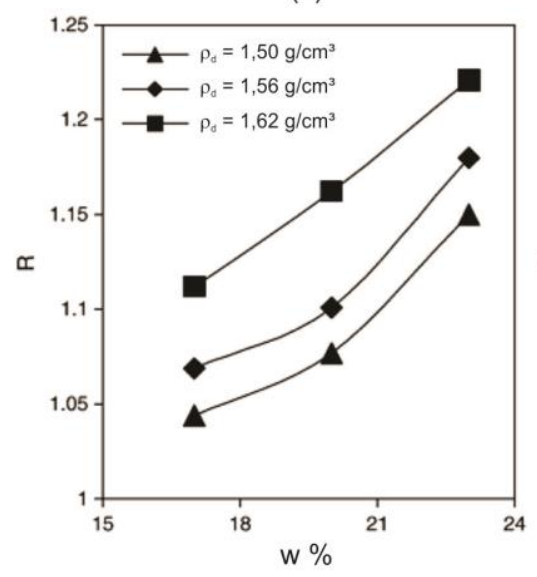

(b)

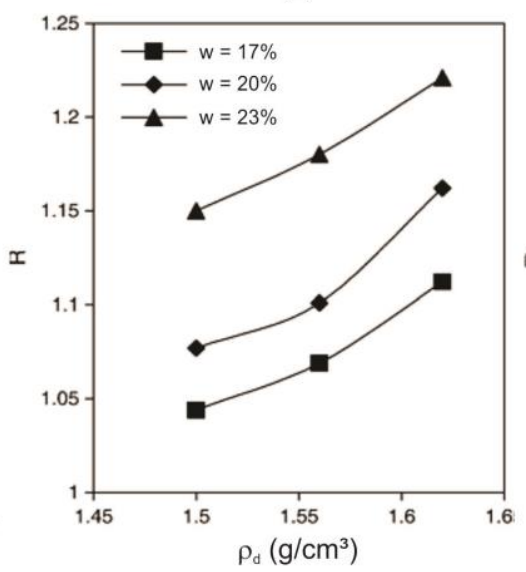

(c)

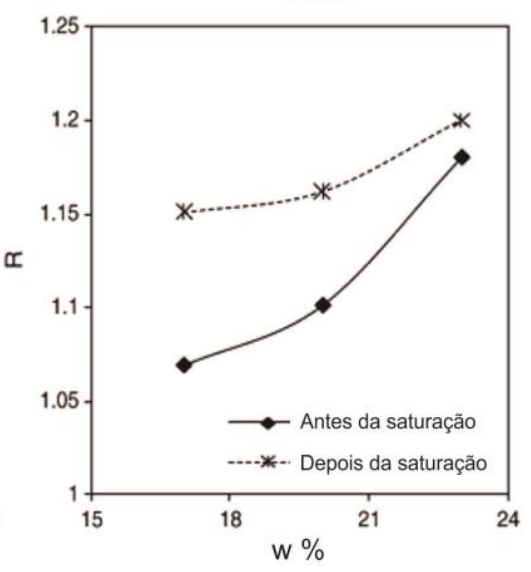

Figura 21 - Anisotropia de resistência não drenada em condições saturadas e não saturadas: (a) influência da umidade; (b) influência da massa específica seca e (c) influência da condição de saturação das amostras compactadas com $\rho_{d}=1,56 \mathrm{~g} / \mathrm{cm}^{3}$. (ROWSHANZAMIR; ASKARI, 2010).

Ham et al. (2012) investigaram a influência da orientação das amostras na resistência ao cisalhamento e deformabilidade, por meio de uma série de ensaios de compressão triaxial do tipo drenado em um solo residual de granito. A Figura 22 ilustra a influência da orientação dos corpos de prova na obtenção dos parâmetros de resistência efetiva do solo estudado por Ham et al. (2012). Nota-se na Figura 22 que a orientação dos corpos de prova pouco interferiu no ângulo de atrito, entretanto, para as amostras não saturadas o intercepto coesivo aumentou conforme a orientação dos corpos de prova se aproximou da direção vertical $\left(\theta=90^{\circ}\right)$. Dessa maneira, a condição mais crítica seria para os corpos de prova talhados na direção paralela ao plano de compactação $\left(\theta=90^{\circ}\right)$. A partir disso, os autores concluíram que o intercepto coesivo obtido na condição não saturada é sensível a orientação dos corpos de prova.

Em linhas gerais, pode-se afirmar que para os solos compactados existe uma tendência de que a resistência não drenada na direção vertical $\left(\theta=90^{\circ}\right)$ seja maior que na direção horizontal $\left(\theta=0^{\circ}\right)$ (SILVA, 1996; CRISPIM, 2010; HAM et al., 2012). 


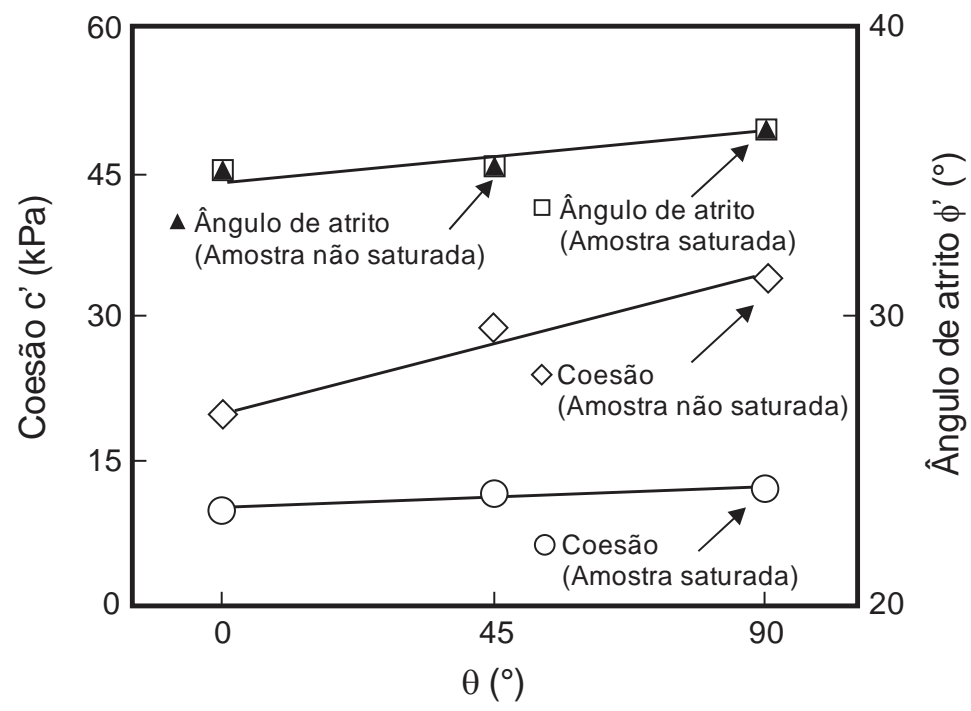

Figura 22 - Parâmetros de resistência obtidos em ensaios do tipo CD em diferentes inclinações de moldagem para condição saturada e não saturada. (HAM et al., 2012).

\subsubsection{Deformabilidade}

A anisotropia das propriedades elásticas depende principalmente da microestrutura do solo e, subordina-se às propriedades físicas das partículas e ao nível de carregamento imposto no solo (ZENG; NI, 1999).

Normalmente a rigidez do solo para pequenas deformações se comporta de maneira anisotrópica (BELLOTTI et al., 1996; JIANG et al., 1997). Mediante a propagação de ondas cisalhantes em corpos de prova adensados isotropicamente, é possível constatar que a rigidez no plano horizontal $\left(G_{0 h}, E_{0 h}\right)$ é 20 a $30 \%$ maior que no plano vertical $\left(G_{0 v}, E_{0 v}\right)$ (BELLOTTI et al., 1996). No entanto, por meio de ensaios triaxiais com carregamentos cíclicos aplicados em corpos de prova cúbicos, Jiang et al. (1997) obtiveram rigidez superior nos planos verticais em relação aos horizontais. Portanto, obtiveram-se relações do tipo $\left(E_{0 h} / E_{O v}\right)$ menores que 1.

Ham et al. (2010) observaram que os módulos de elasticidade secantes $\left(E_{\text {sec }}\right)$ para $\varepsilon_{a}=0,001 \%$ são pouco influenciados pela inclinação das amostras, ângulo $\theta$. Afirmaram também que para muito pequenas deformações não é possível mobilizar a estrutura do solo, portanto, a rigidez em baixas deformações não é afetada pela direção de talhagem das amostras (KONGSUKPRASERT, SANO; TATSUOKA, 2007; HAM et al., 2010).

O bender elements, como uma ferramenta eficaz na determinação do módulo de cisalhamento do solo, se mostra útil também no estudo da anisotropia inerente ou induzida por um estado de tensões (ZENG; NI, 1999). A técnica vem sendo utilizada na obtenção da 
resposta dinâmica em diferentes planos de polarização. Vários pesquisadores se propuseram a estudar o efeito da direção de emissão de ondas em solos saturados, por outro lado análises a partir de solos em condição não saturada ainda são escassos (NG; YUNG, 2008).

A análise da anisotropia de rigidez pode ser conduzida tanto e termos da relação entre módulos de cisalhamento $\left(G_{0 h} / G_{0 v}\right)$ como mediante relação das velocidades da onda cisalhante $\left(V_{s h} / V_{s v}\right)$. Na Equação 8 pode ser observada a igualdade das duas relações (NG; YUNG, 2008).

$$
\frac{G_{0 h}}{G_{0 v}}=\left(\frac{V_{s h}}{V_{s v}}\right)^{2}
$$

Onde: $G_{0 h}=$ módulo de cisalhamento no plano horizontal; $G_{0_{v}}=$ módulo de cisalhamento no plano vertical; $V_{s h}=$ velocidade da onda de cisalhamento propagada no plano horizontal e $V_{s v}=$ velocidade da onda de cisalhamento propagada no plano vertical.

A Figura 23 retrata a influência da sução matricial e tensão confinante na relação $G_{0 h} / G_{0 v}$. Nota-se que a anisotropia varia de 1,03 a 1,09 , e tende a aumentar com o incremento da tensão confinante e também com o acréscimo da sucção matricial. $\mathrm{Ng}$ e Yung (2008) acreditam que a sucção matricial rege o desempenho do solo em valores maiores que a pressão de entrada de ar. Portanto, a sução matricial pode influênciar diretamente na magnitude das anisotropias de rigidez (LI, 2003).

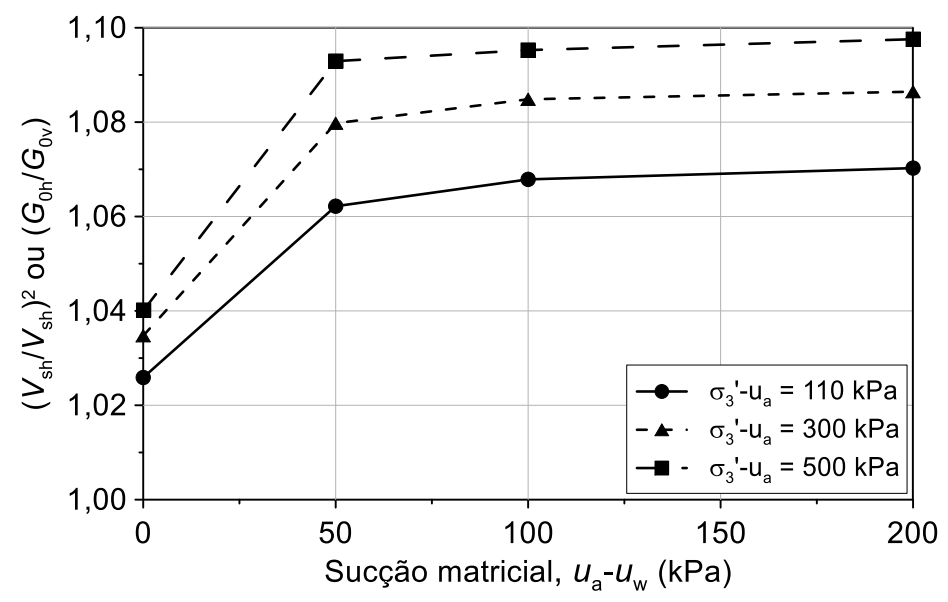

Figura 23 - Influência da sucção matricial na anisotropia de deformabilidade (Adaptada de NG; YUNG, 2008). 


\subsubsection{Condutividade hidráulica}

$\mathrm{Na}$ engenharia geotécnica normalmente assume-se que o fluxo paralelo à orientação das camadas é maior do que na direção vertical. Na maioria das vezes, este fato é justificado por possíveis imperfeições na interface entre camadas, ou por orientação de partículas promovidas por esforços aplicados durante a compactação (BOYNTON; DANIEL, 1985; KIM, 1996).

Boynton e Daniel (1985) estudaram a anisotropia na condutividade hidráulica $\left(k_{h} / k_{v}\right)$ de uma argila compactada. A Figura 24 ilustra a influência do teor de umidade de compactação nas propriedades hidráulicas estudadas por Boynton e Daniel (1985). As condutividades hidráulicas das amostras compactadas no ramo seco apresentaram pouca influência da direção de talhagem, por outro lado, com o acréscimo do teor de umidade de compactação a relação $\left(k_{h} / k_{v}\right)$ se aproximou de 1,20 (Figura 24). Desse modo, os referidos autores acreditam que essa pequena variação não indica que o solo estudado se comportou de maneira anisotrópica.

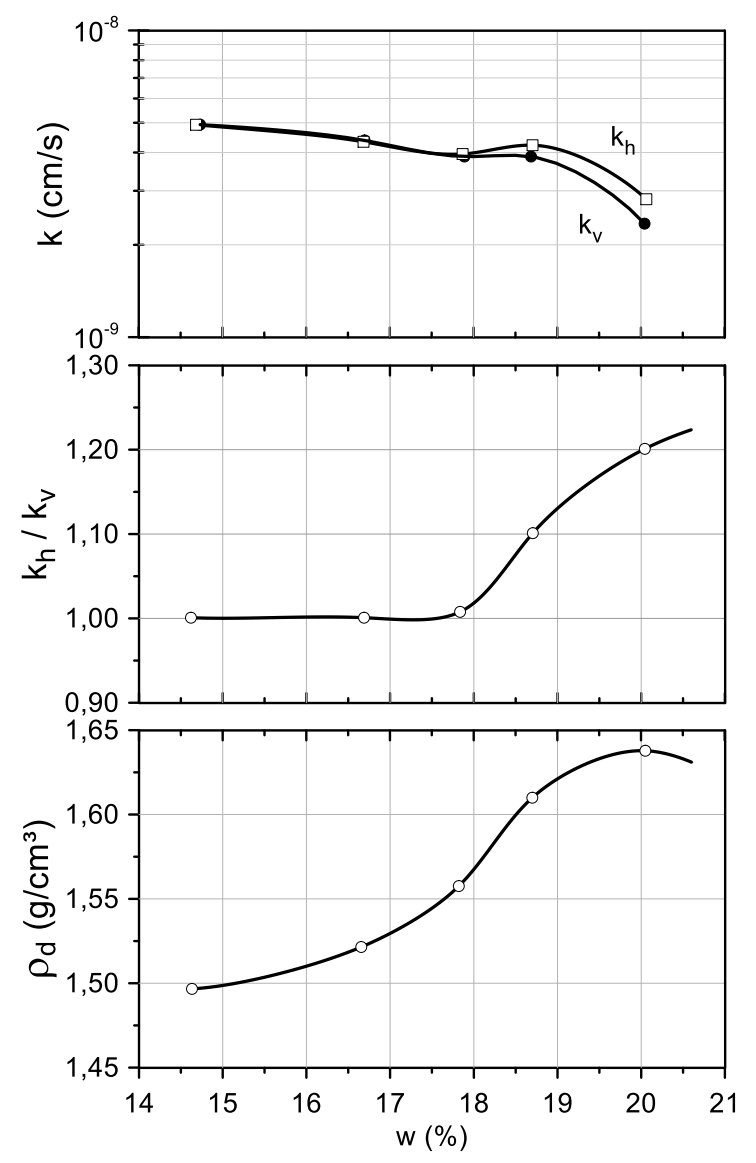

Figura 24 - Efeito da direção do fluxo na condutividade hidráulica de uma argila compactada (Adaptada de BOYNTON; DANIEL, 1985). 
Os referidos autores afirmam que essas pequenas diferenças no valor da condutividade hidráulica estaria atrelada ao efeito do gradiente da massa específica seca nas amostras compactadas. Isto porque durante a compactação dos corpos de prova, as camadas inferiores absorvem maiores quantidades de energia, promovendo a redução nos valores de $\rho_{d}$, interferindo, portanto, na variabilidade dos índices físicos, comprometendo a confiabilidade da condutividade hidráulica nos corpos de prova talhados.

Além do teor de umidade de compactação, o tipo de solo também tem influência direta no comportamento hidráulico. A utilização de solos finos compactados apresenta-se como uma alternativa viável para aplicação em núcleos de barragens ou como barreiras de proteção em aterros sanitários (OSINUBI; NWAIWU, 2002, 2005, 2006; SILVA, 2015). A verificação do desempenho nessas obras deve levar em consideração as possíveis direções de fluxo, uma vez que nessas condições as características hidráulicas do material compactado devem atender às recomendações de projeto.

Diversos fatores são responsáveis por promover alterações estruturais no solo, dentre os quais se destaca a tensão de confinamento. Este estado de tensões pode desenvolver estruturas diferentes daquelas formadas durante a compactação, afetando significativamente a condutividade hidráulica do solo. A redução do índice de vazios, promovida pela tensão de confinamento aplicada, é responsável por proporcionar mudanças estruturais no solo diminuindo, assim, a sua condutividade hidráulica (SHAFIEE, 2008). Cruz (1999) observou elevada relação $k_{h} / k_{v}$ em barragens brasileiras construídas com aterros de 10 a 20 metros de altura, por outro lado, para barragens ainda maiores, o referido autor observou uma redução desta relação. Sendo assim, a tensão de confinamento pode contribuir consideravelmente na magnitude da anisotropia de condutividade hidráulica.

Shafiee (2008) avaliou a influência da tensão de confinamento na anisotropia de condutividade hidráulica a partir de agregados adicionados a um solo argiloso medianamente plástico. Para isso, compactou amostras com diferentes percentuais da mistura e talhou os corpos de prova em duas direções distintas (vertical e horizontal), frente à orientação das camadas compactadas. Esses corpos de provas foram submetidos a tensões de confinamento pré-definidas e, após cada acréscimo de tensão, foi realizado um ensaio de condutividade hidráulica.

Na Figura 25 consta parte dos resultados obtidos por Shafiee (2008). Nela observase que as condutividades hidráulicas verticais e horizontais diminuem com o acréscimo da tensão de confinamento. Observa-se na Figura $25 \mathrm{~b}$ a redução da relação $k_{h} / k_{v} \operatorname{com} 0$ aumento da tensão de confinamento. Nota-se que para baixas tensões de confinamento, o fluxo paralelo à direção das camadas de compactação é aproximadamente 5 vezes maior na direção paralela ao plano de compactação do que na direção ortogonal e, tende a diminuir 
com aumento da tensão de confinamento. A partir de certa tensão de confinamento, o solo torna-se mais homogêneo, ou seja, a relação $k_{h} / k_{v}$ se aproxima a 1.
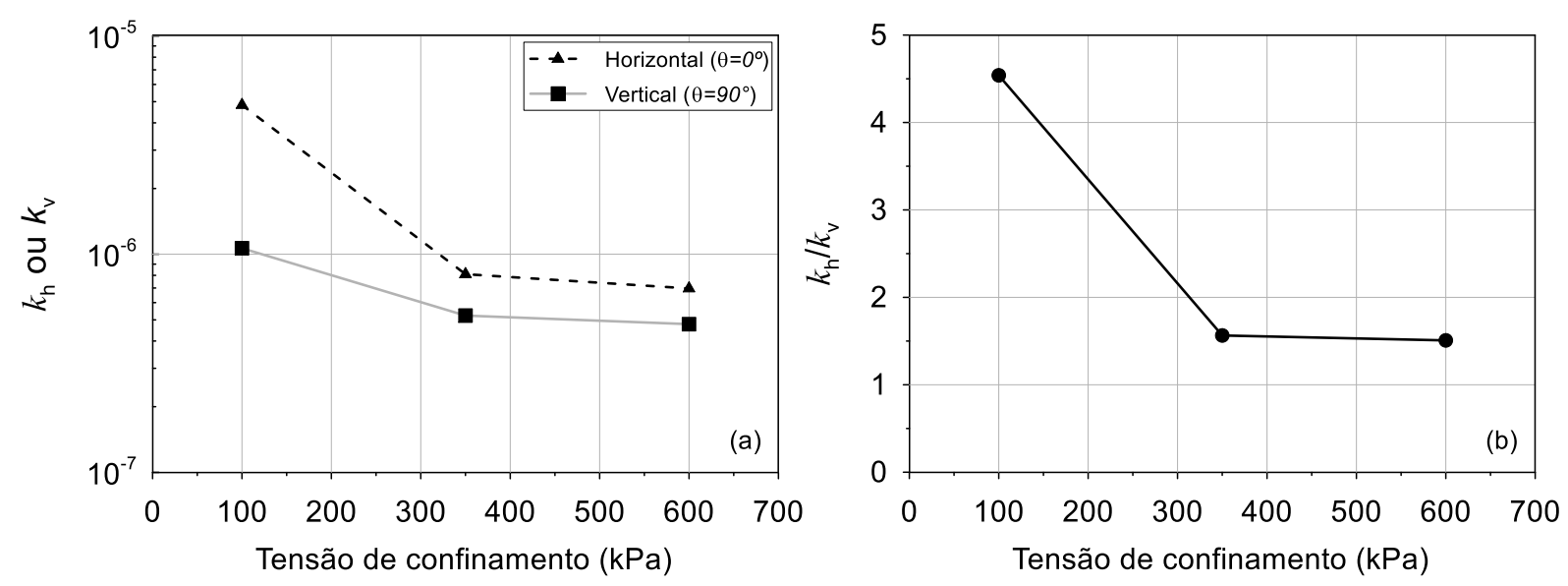

Figura 25 - Influência da tensão de confinamento: (a) na condutividade hidrálica orientadas frente ao plano de compactação; (b) na anisotropia (Adaptada de SHAFIEE, 2008), 


\section{MATERIAIS E MÉTODOS}

\subsection{Material de análise}

O solo estudado na presente pesquisa foi coletado no Campus 2 da Universidade de São Paulo (Figura 26), no município de São Carlos (SP). Tal região foi escolhida por apresentar solos bem evoluídos, típicos do interior do estado de São Paulo. Além disso, diversas pesquisas de mestrado e doutorado utilizaram solos desta região, o que favorece futuras comparações entre resultados.

O solo desta região está localizado sobre rochas do Grupo São Bento, no qual fazem parte arenitos da Formação Botucatu e rochas básicas da Formação Serra Geral. Superficialmente afloram sedimentos Cenozoicos que passaram por intemperismo proveniente das condições climáticas impostas. Portanto, quando in situ, esse solo apresenta elevada porosidade, sendo eventualmente colapsível. No entanto, quando compactados, estes solos mostram-se apropriados para aplicação na engenharia devido à melhoria de suas propriedades mecânicas e hidráulicas (SILVA, 1996).
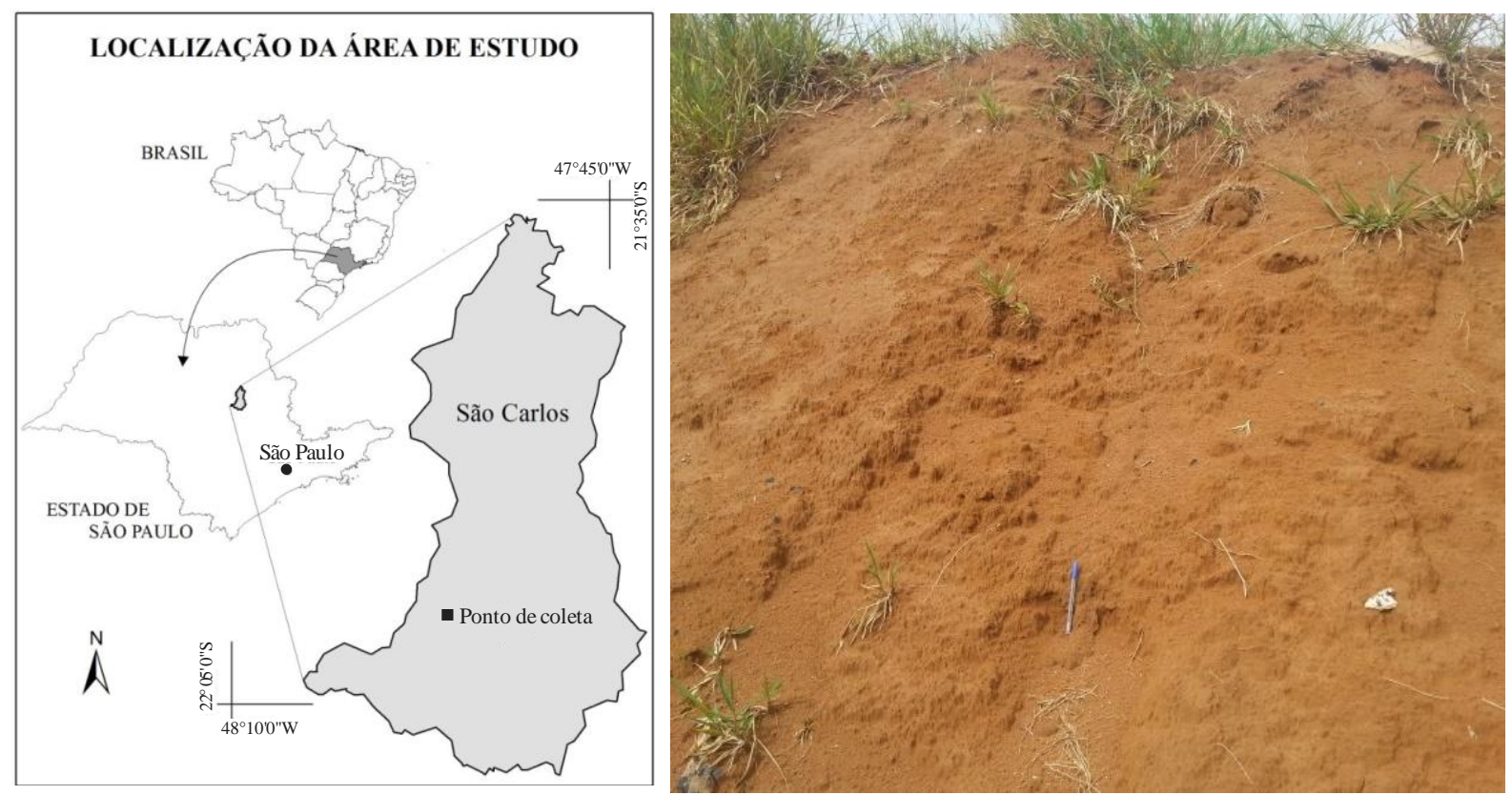

Figura 26 - Local de coleta do solo estudado. 
4.2 Ensaios de caracterização geotécnica e compactação

Os ensaios de caracterização geotécnica foram realizados no Laboratório de Mecânica dos Solos do Departamento de Geotecnia da Escola de Engenharia de São Carlos. Durante a realização dos ensaios seguiu-se as recomendações da Associação Brasileira de Normas Técnicas (ABNT).

A caracterização geotécnica do solo estudado foi realizada segundo as seguintes normas brasileiras: massa específica dos sólidos (ABNT, 1984a); análise granulométrica conjunta (ABNT, 1984b) à exceção do uso do defloculante e do dispersor elétrico; limite de liquidez (ABNT, 1984c); limite de plasticidade (ABNT, 1984d); compactação utilizando energia Proctor Normal (ABNT, 1986).

Durante o ensaio de granulometria conjunta optou-se por avaliar a influência do método de ensaio adotado na obtenção da curva granulométrica do solo estudado. Normalmente, em solos lateríticos, realiza-se o ensaio com e sem a presença de defloculante para que se avalie o efeito da agregação das partículas, advindas do processo de laterização, associada a sua formação. Além disso, o solo em condições de campo não é submetido a agentes dispersantes, o que favorece a realização da granulometria sem a presença de qualquer agente dispersante (físico e químico). Desse modo, adotou-se três diferentes metodologias para obtenção da curva granulométrica do solo estudado, a saber:

- Curva A: Obtida da maneira tradicional, mantendo a amostra repousando em água destilada por um período de 24 horas, submetendo-a a ação do defloculante químico e dispersão mecânica a 10000 rpm e, por fim, foi realizada agitação manual, previamente a fase de sedimentação.

- Curva B: Obtida da maneira não tradicional, mantendo a amostra em prévia saturação, por um período de 24 horas, sem a presença de defoculante, a amostra foi submetida à dispersão mecânica e por fim, a mesma foi conduzida a agitação manual, previamente a fase de sedimentação.

- Curva C: Obtida da maneira não tradicional, mantendo a amostra em prévia saturação por um período de 24 horas, sem a presença de defloculante químico e sem ação da dispersão mecânica e por fim, foi realizada agitação manual, previamente a etapa de sedimentação.

As diferenças entre as Curvas A, B e C indicam a presença de agregações no solo. $A$ relação entre as curvas granulométricas com a presença de defloculante (Curva $A$ ) e sem defloculante (Curva B ou Curva C) pode ser interpretada por meio da Equação 9. 
Otálvaro (2013), utilizando o conceito da agregação relativa (AR), avaliou as mudanças entre as curvas de distribuição acumulada por meio da prévia transformação das abscissas para escala logarítmica e, posterior cálculo da área sob a curva de distribuição granulométrica (Equação 9).

$$
\mathrm{AR}=\frac{\left|\int_{x_{0}}^{x_{f}} W^{a g} d x-\int_{x_{0}}^{x_{f}} W^{i} d x\right|}{\int_{x_{0}}^{x_{f}} W^{i} d x} \times 100
$$

Onde: $x_{0}$ e $x_{f}=$ logaritmos dos diâmetros mínimo e máximo da curva granulométrica; $W^{a g}=$ porcentagem acumulada na curva sem defloculante (Curva B ou Curva C); $W^{i}=$ porcentagem acumulada na curva com defloculante (Curva A).

\subsubsection{Classificação geotécnica MCT}

Tendo em vista as limitações das classificações atualmente disponíveis, pode-se recorrer à metodologia designada MCT (Miniatura, Compactado, Tropical), específica para solos tropicais compactados. Esta sistemática tenta representar as condições reais da compactação da camada do pavimento (VILLIBOR; NOGAMI, 2009). Os ensaios necessários para esta classificação abrangem basicamente: Mini-MCV e Perda de Massa por Imersão. Na Figura 27 é apresentado o esquema utilizado para compactação dos corpos de prova através do equipamento miniatura (Mini-MCV). Essa etapa foi baseada na norma DNER ME 258 (DNER, 1994b).

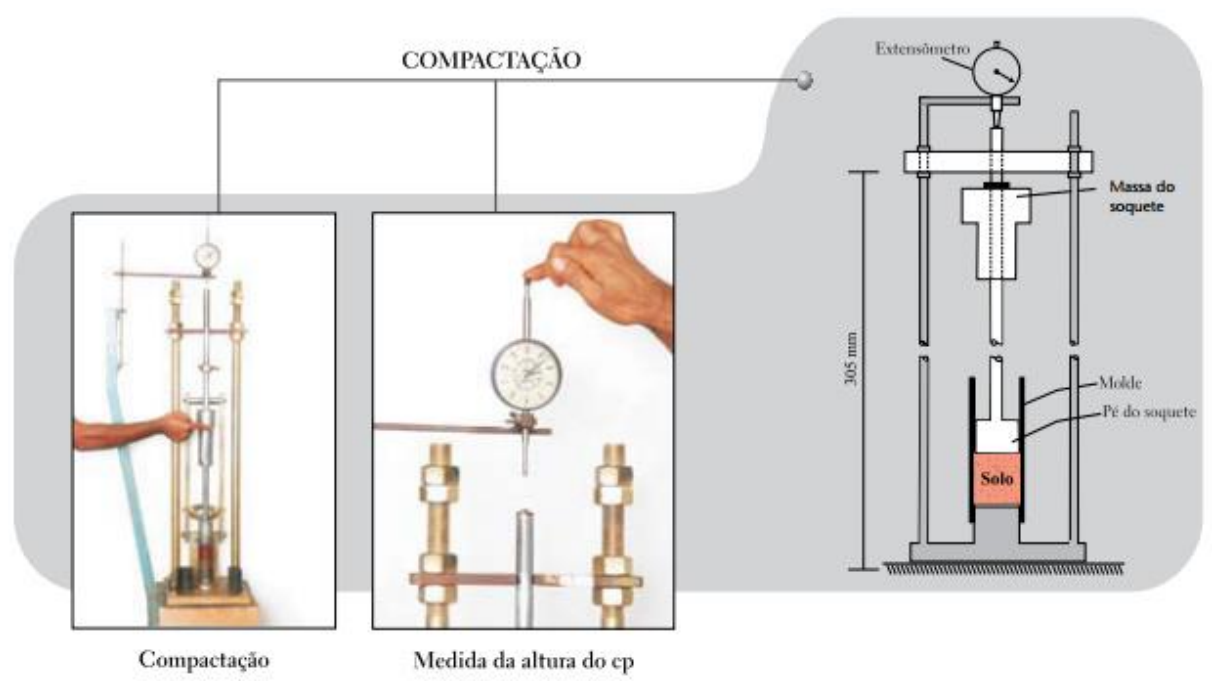

Figura 27 - Croqui do ensaio (VILLIBOR; NOGAMI, 2009). 
O ensaio de perda de massa por imersão foi realizado seguindo a norma DNER ME 256 (DNER, 1994a). A Figura 28 mostra o ensaio em andamento, onde os resultados são obtidos em função da massa seca que se desprende do corpo de prova referente a um comprimento extrudado de $10 \mathrm{~mm}$.

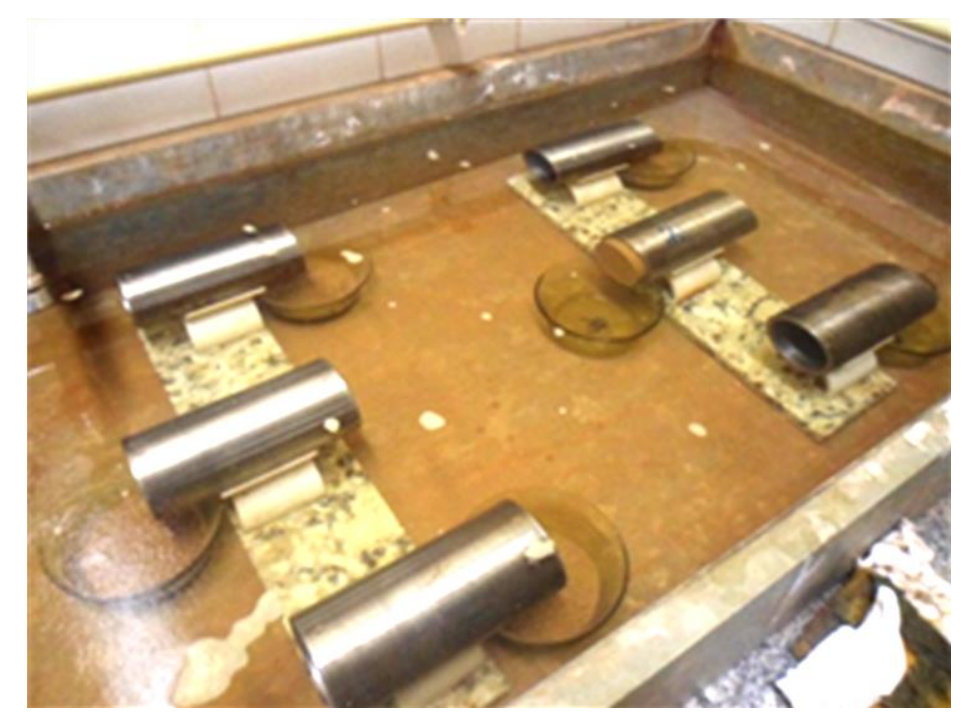

Figura 28 - Ensaio de perda de massa por imersão.

A partir dos resultados obtidos durante a fase de compactação e perda de massa por imersão, foram elaboradas três curvas: Deformabilidade ou Mini-MCV; Compactação e Perda de massa por imersão x Mini-MCV. O fluxograma dos ensaios (Figura 29) indicam os coeficientes necessários para a classificação MCT, acompanhados das respectivas curvas mediante as quais foram obtidos. Maiores detalhes quanto ao tratamento dos dados podem ser consultados em Nogami e Villibor (1995).

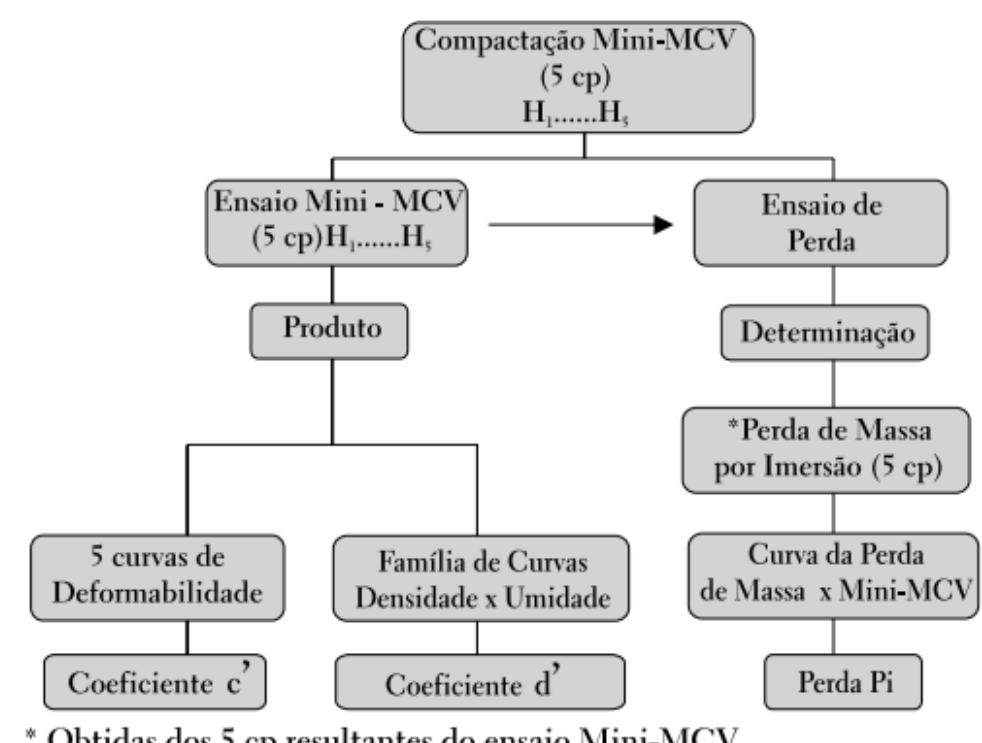

* Obtidas dos 5 cp resultantes do ensaio Mini-MCV.

Figura 29 - Fluxograma Mini-MCV e ensaio associado da perda de massa (VILLIBOR; NOGAMI, 2009). 


\subsection{Caracterização físico-química e mineralógica}

O conhecimento da mineralogia do solo é uma ferramenta para a determinação de sua gênese, servindo de indicativo na avaliação físico e químico do material. Para este fim, recorreu-se ao ensaio de adsorção de azul de metileno e difração de raio-X.

\subsubsection{Ensaio de Adsorção de Azul de Metileno}

Pejon (1992) e Fabbri (1994) observaram que o ensaio de adsorção de azul de metileno é uma ferramenta eficaz na caracterização da fração fina dos solos tropicais. Em solução aquosa, o azul de metileno (cloridrato de metiltiamina) apresenta-se dissociado em cátions de metileno e ânions cloreto. Por meio desse método foi possível obter alguns parâmetros úteis na identificação dos principais argilominerais presentes na fração fina dos solos, dos quais destacam-se: a superfície específica (SE); a capacidade de troca catiônica (CTC); e o índice de atividade da fração argila (Acb).

A preparação do solo para esse ensaio se deu pelo seu peneiramento em malha com abertura de 0,038 mm. Após o peneiramento, utilizou-se cerca de $1 \mathrm{~g}$ de material, o qual foi dissolvido em água. Adicionou-se, então, azul de metileno ao conjunto que em seguida foi agitado através de agitador magnético. Após a agitação, uma gota da mistura foi aplicada, por meio de um bastão de vidro, sobre um papel filtro.

Caso a adição de uma gota de solução sobre o papel filtro não forme uma auréola azul (resultado positivo), o teste é considerado negativo. Em caso de teste negativo, adiciona-se uma nova quantidade de azul de metileno e, então, o teste é refeito até que seja considerado positivo. Para maiores detalhes e especificações, recomenda-se a leitura de Pejon (1992).

Por meio do volume de solução gasto até que o teste seja considerado negativo $\left(\mathrm{V}_{\mathrm{a}}\right)$, pode-se calcular a capacidade de troca catiônica do argilomineral predominante no solo (CTC), Equação 10.

$$
\mathrm{CTC}=\frac{V_{a} \times C \times 100}{M_{s}}
$$

Onde: $V_{a}=$ valor de solução gasto; $C=$ concentração da solução; $M_{s}=$ massa seca de solo. 
Além da capacidade de troca catiônica outros parâmetros também são úteis na caracterização do argilomineral do solo como a superfície específica (SE), o valor de azul de metileno $\left(V_{b}\right)$ e a atividade da fração argila (Acb), sendo possível de serem calculadas utilizando as Equações 11, 12 e 13, respectivamente.

$$
\begin{aligned}
& \mathrm{SE}=\frac{3,67 \times V_{a}}{M_{s}} \\
& V_{b}=\frac{1,5 \times V_{a} \times 100}{M_{s}}
\end{aligned}
$$

$$
\mathrm{Acb}=100 \times \frac{V_{b}}{p(<0,005)}
$$

Onde: $p(<0,005)$ - fração da amostra menor que 0,005 mm.

A partir da atividade da fração argila foi possível identificar o grupo de argilominerais no qual faz parte o solo analisado. Na Tabela 3, consta a atividade dos principais grupos de argilominerais, para auxílio na classificação expedita de solos tropicais. Para solos lateríticos, normalmente considera-se que valor de Acb seja menor do que 11, neste caso, o material também é considerado como pouco ativo (FABBRI, 1994).

Tabela 3 - Valores de azul de metileno e atividade da fração argila em função da superfície específica

\begin{tabular}{cccc}
\hline $\begin{array}{c}\text { Grupo de } \\
\text { Argilominerais }\end{array}$ & SE $\left(\mathrm{m}^{2} / \mathrm{g}\right)$ & Acb $\left(10^{-3} \mathrm{~g} / \mathrm{g}\right)$ & $\begin{array}{c}\text { Grau de } \\
\text { atividade }\end{array}$ \\
\hline Montmorilonitas & 860 & 350 & Muito Ativo \\
Vermiculitas & 200 & 82 & Ativo \\
Ilitas & 74 & 30 & Pouco Ativo \\
Caulinitas & 48 & 20 & \\
Laterizados $^{(1)}$ & 27 & 11 & \\
\hline (1)Superfície específica para $A c b=11$ & &
\end{tabular}




\subsubsection{Difração de Raios-X}

A Difratometria de Raios-X (DRX) é uma técnica não destrutiva que consiste em determinar a distância interplanar $(d)$ através do ângulo de reflexão $(\theta)$ de uma onda com comprimento conhecido $(\lambda)$, originando assim, o fenômeno da difração (Figura 30). Este fenômeno se dá quando a onda emitida enfrenta um obstáculo de dimensão semelhante ao seu comprimento de onda (MUKHERJEE, 2013). A utilização dessa técnica tem como objetivo principal a identificação dos possíveis minerais constituintes, através de análise qualitativa e quantitativa.

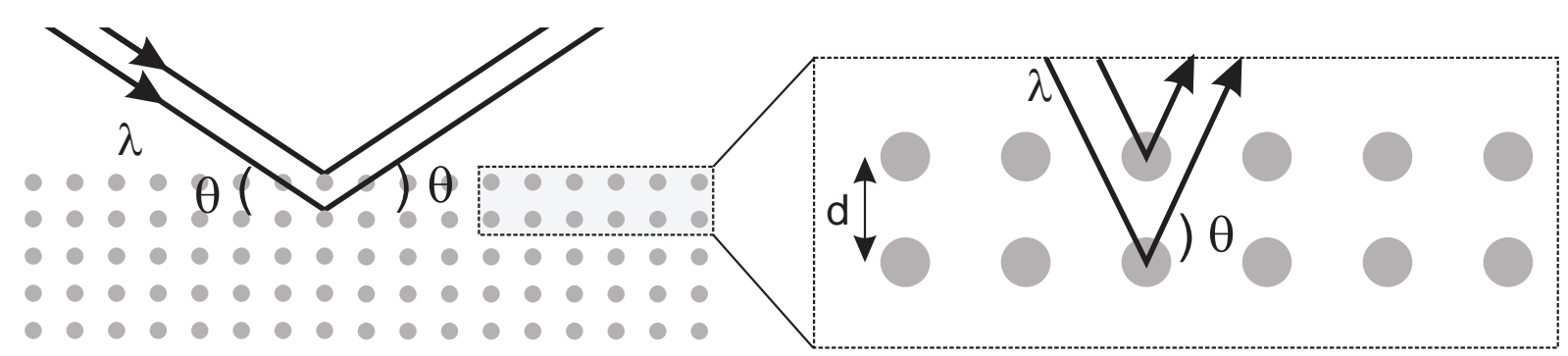

Figura 30 - Princípo de lei de Bragg (Adaptada de MUKHERJEE, 2013).

Para essa etapa do estudo foi utilizada a equação que leva em consideração a Lei de Bragg. Por meio desta lei é possivel determinar a distância basal $(d)$ utilizando o ângulo formado entre o raio incidente, com o plano cristalino $(\theta)$, Equação 14. Após a obtenção das distâncias basais, os minerais presentes nas amostras foram identificados com base nas informações contidas nas tabelas presentes em Brindley e Brown (1980) e Moore e Reynolds (1989).

$\lambda=2 \times d \times \operatorname{sen} \theta$

$\mathrm{Na}$ fase de preparação das amostras, estas foram secas ao ar e passadas na peneira com malha de 0,038 mm, \#400 (ASTM, 2015), para que assim, o material estudado fosse o mais representativo possível da fração argila do solo. Após peneiramento, a fração do solo foi dispersa em solução aquosa de hexametafosfato de sódio, a fim de que o resultado fosse o mais representativo possível da fração do solo analisada. Por sua vez, o material foi suspenso sobre lâminas de vidro (Figura 31a), por um período de 24 horas, e então, o excesso de água foi retirado e as lâminas foram secas ao ar (Figura 31b). 

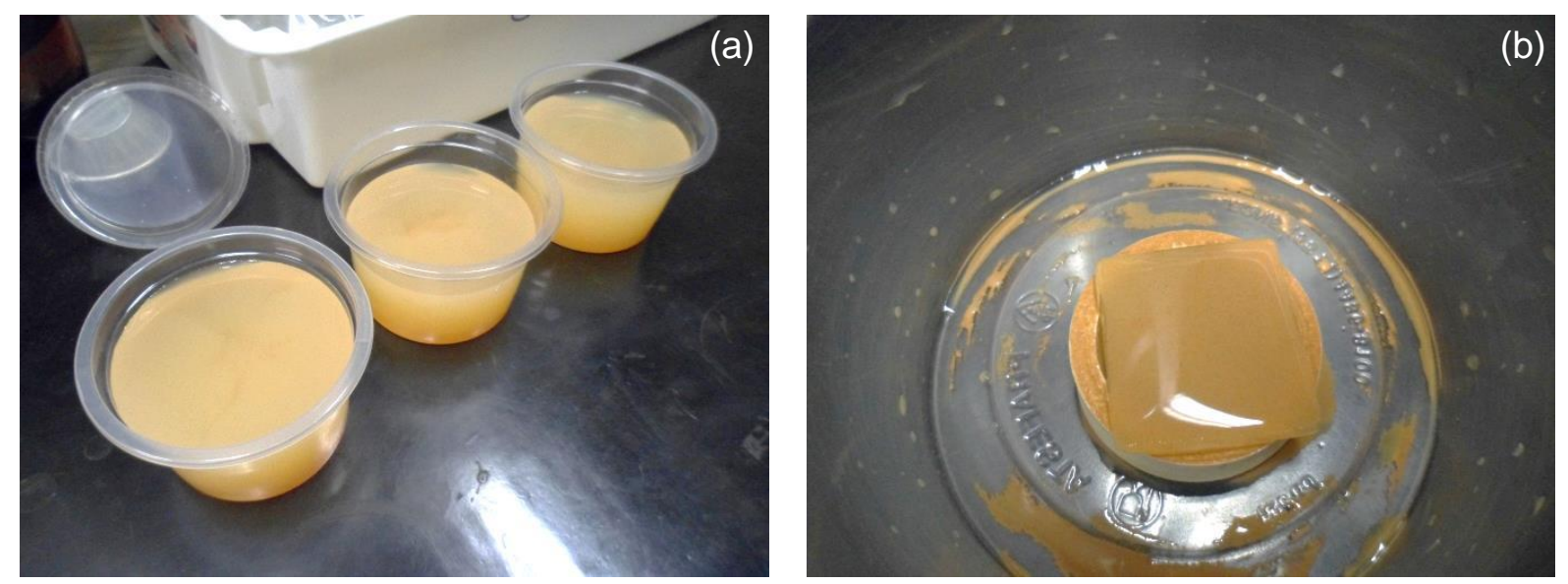

Figura 31 - Preparo das lâminas de DRX: (a) em fase de decantação;

(b) em fase de secagem ao ar.

Os procedimentos utilizados na confecção das lâminas seguiram as recomendações de Santos (1989). Ao todo foram confeccionadas três lâminas, uma delas não recebeu nenhum tratamento, já as outras duas receberam tratamentos especiais a fim de auxiliar a identificação do mineral.

Um dos tratamentos, denominado de solvatação, utiliza etileno-glicol na identificação de argilominerais que detém a propriedade de aumentar sua distância basal $(d)$ frente algum tipo de hidratação. Outro tratamento utilizado é o aquecimento a $550^{\circ} \mathrm{C}$ em mufla por um período de 3 horas, o qual tem como função eliminar as moléculas de água adsorvidas.

Os ensaios de difratometria de Raio-X foram realizados no Instituto de Física de São Carlos (IFSC) da Universidade de São Paulo (USP).

\subsection{Ensaios de Porosimetria por Intrusão de Mercúrio}

Os ensaios de Porosimetria por Intrusão de Mercúrio (PIM) foram realizados no Instituto de Física de São Carlos (IFSC) na Universidade de São Paulo (USP), utilizando-se do PoroSizer 9320 da Micrometrics Instrument Corporation, o qual apresenta capacidade máxima de aplicação de 30.000 psi de pressão de injeção de mercúrio. Com essa pressão, o equipamento consegue preencher somente poros maiores que $6 \mathrm{~nm}$.

A importância de se utilizar o mercúrio nessa análise baseia-se no princípio de que este elemento não se comporta como um fluído molhante, ou seja, para que penetre em qualquer orifício pequeno é necessário que se aplique pressão. $O$ ensaio consiste 
basicamente em aplicar sucessivas pressões de mercúrio, registrando o volume penetrado no solo.

\subsection{Preparação dos corpos de prova}

As preparações dos corpos de prova foram efetuadas por meio da compactação das amostras e sua posterior talhagem a fim de prepará-los para os ensaios de compressão confinada, condutividade hidráulica, compressão triaxial e os bender elements.

$\mathrm{Na}$ fase de preparação, o solo foi seco em estufa com temperatura menor que $40^{\circ} \mathrm{C}$, homogeneizado, quarteado e posteriormente armazenado em sacos plásticos. Antes da fase de compactação houve a adição da quantidade de água necessária para que se atingisse o teor de umidade desejado, a partir disso o material foi condicionado em sacos plásticos e mantido em câmara úmida por um período de 48 horas.

Durante a compactação, as amostras foram preparadas de modo a atender os índices físicos correspondentes a alguns pontos específicos da curva de compactação, como o ramo seco, a umidade ótima e o ramo úmido. Para tanto, foram ajustadas a quantidade de massa úmida e a altura de cada camada compactada, para que o resultado final fosse o mais próximo possível do apresentado na Tabela 4.

Tabela 4 - Índices físicos alvo para a compactação das amostras

\begin{tabular}{ccccccc}
\hline & $\rho_{d}$ & $\mathrm{GC}$ & $w$ & $\mathrm{e}^{(1)}$ & $\mathrm{n}^{(1)}$ & $S_{r}$ \\
& $\left(\mathrm{~g} / \mathrm{cm}^{3}\right)$ & $(\%)$ & $(\%)$ & - & $(\%)$ & $(\%)$ \\
\hline Ramo seco & 1,697 & 95,3 & 13,0 & 0,58 & 36,80 & 59,90 \\
Umidade ótima & 1,780 & 100,0 & 15,5 & 0,50 & 33,75 & 81,80 \\
Ramo úmido & 1,735 & 97,5 & 17,0 & 0,55 & 35,40 & 83,30 \\
\hline (1) calculados com $\rho_{\mathrm{s}}=2,686 \mathrm{~g} / \mathrm{cm}^{3}$. & & & &
\end{tabular}

Para a confecção de cada amostra foi utilizado um cilindro grande (cilindro CBR), o qual segue as dimensões padronizadas pela ABNT NBR 7182 (ABNT, 1986). No entanto, o soquete utilizado não foi o recomendado pela referida norma, visto que a aplicação dos esforços foi promovida pelo compactador presente na Figura 32a. Cabe salientar que cada golpe foi distribuído uniformemente sobre a superfície de cada camada, no intuito de facilitar a obtenção dos índices físicos alvo (Tabela 4). 
A sequência utilizada na moldagem de cada amostra obedeceu algumas etapas, a saber:

1) homogeneização do solo;

2) adição da quantidade de água necessária;

3) acondicionamento do solo em saco plástico, com seu posterior repouso em câmara úmida por um período não inferior a 48 horas;

4) acondicionamento em recipientes plásticos fechados de uma porção de massa úmida correspondente ao necessário para compactação de cada camada. Houve a necessidade da utilização de umidificador nas proximidades do local, visando redução da evaporação da água adicionada no item 2;

5) lubrificação do cilindro metálico utilizando vaselina líquida;

6) inserção no interior do cilindro da porção descrita no item 4;

7) posicionamento da base do soquete sobre a amostra e posterior queda livre do martelo (Figura 32b);

8) controle da altura por meio de guia (gabarito) com marcações do limite de cada camada, localizadas na parte superior do compactador, como se vê na Figura 32b;

9) escarificação de cada camada utilizando pincel com cerdas de aço mediante movimentos circulares ao longo de toda seção (Figura 32c), visando a uniformização do processo e diminuição de possíveis sulcos preferenciais;

10) tingimento do solo através da aspersão de uma solução de azul de metileno ao longo da seção escarificada (Figura 32d);

11) repetição dos processos: $6,7,8,9$ e 10, até que o cilindro metálico seja preenchido por completo;

12) com auxílio de um extrator mecânico removeu-se a amostra contida no interior do molde cilíndrico (Figura 32e). 

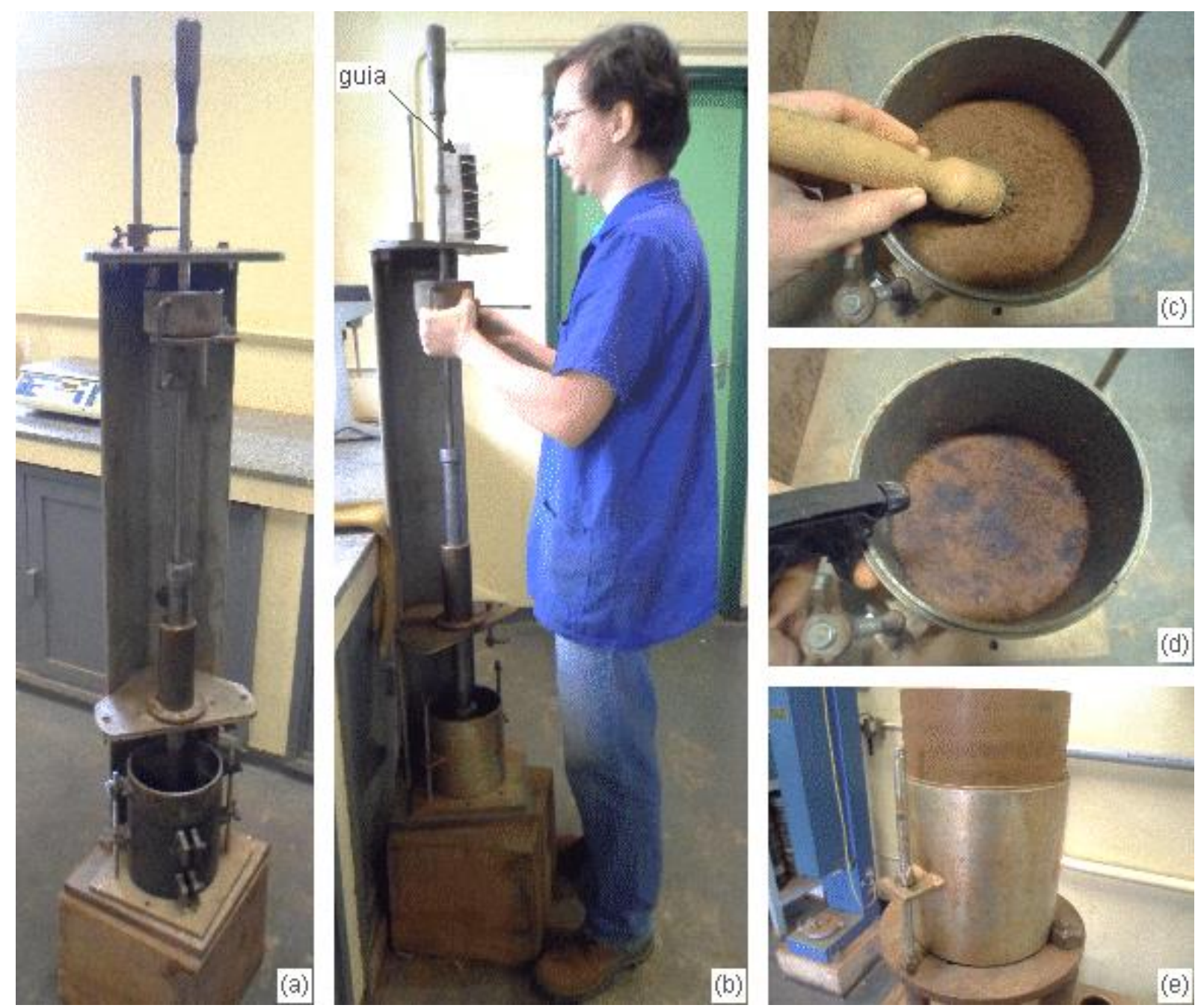

Figura 32 - Compactação das amostras: (a) equipamento utilizado; (b) execução da compactação; (c) escarificação; (d) aspersão do azul de metileno; (e) extração da amostra.

\subsubsection{Controle de compactação}

Na moldagem dos corpos de prova por camadas, pode surgir ao longo do corpo de prova um fenômeno denominado de gradiente da massa específica seca, devido a possibilidade de uma camada de compactação absorver uma maior quantidade energia do que as camadas sotopostas (AQUINO et al., 2008; AGUIAR, 2010). Portanto, as condições apropriadas de compactação devem ser estabelecidas criteriosamente a fim de evitar tais gradientes (CAMAPUM DE CARVALHO et al., 1987). Segundo Ladd (1978), o gradiente da massa específica seca afeta a representatividade da amostra, e para correção deste efeito, pode-se compactar a primeira camada com uma massa específica menor que as demais, no intuito de que ao final da compactação o corpo de prova seja homogêneo. 
Com o intuito de estudar a interferência da espessura da camada na uniformidade das amostras, foram compactados cinco corpos de prova com diferentes números de camadas. Na Tabela 5 constam as espessuras das camadas de cada corpo de prova, ordenadas na sequência de compactação. O corpo de prova identificado como $7^{\star}$ foi compactado seguindo a metodologia desenvolvida na presente pesquisa, a qual pode ser verificada em maiores detalhes no Apêndice A. Nota-se na referida tabela, que apenas o corpo de prova identificado como $7^{\star}$ apresentou alturas das camadas diferentes entre si.

O desenvolvimento desta metodologia teve como objetivo induzir diferentes massas específicas iniciais, no intuito de que ao compactar cada camada, os esforços transferidos às camadas inferiores fossem responsáveis por corrigir as pequenas diferenças das alturas iniciais previamente estabelecidas. Convém mencionar que toda amostra moldada, nesta fase da pesquisa, se deu pelas condições ótimas, ou seja, $\rho_{d \max }$ e $w_{o t}$.

Tabela 5 - Alturas iniciais em milímetro de cada camada das amostras compactadas

\begin{tabular}{cccccc}
\hline & \multicolumn{5}{c}{ Número de camadas } \\
Sequência (å $)$ & 5 & 7 & $7^{*}$ & 9 & 11 \\
\hline 1 & 25,440 & 18,171 & 18,77 & 14,133 & 11,564 \\
2 & 25,440 & 18,171 & 18,57 & 14,133 & 11,564 \\
3 & 25,440 & 18,171 & 18,37 & 14,133 & 11,564 \\
4 & 25,440 & 18,171 & 18,17 & 14,133 & 11,564 \\
5 & 25,440 & 18,171 & 17.96 & 14,133 & 11,564 \\
6 & - & 18,171 & 17,77 & 14,133 & 11,564 \\
7 & - & 18,171 & 17,57 & 14,133 & 11,564 \\
8 & - & - & - & 14,133 & 11,564 \\
9 & - & - & - & 14,133 & 11,564 \\
10 & - & - & - & - & 11,564 \\
11 & - & - & - & - & 11,564 \\
\hline$\Sigma$ & 127,200 & 127,200 & 127,200 & 127,200 & 127,200 \\
\hline
\end{tabular}

${ }^{*}$ altura variada.

Para verificação das condições de compactação ao longo de cada amostra compactada realizou-se a determinação da massa específica com emprego da balança hidrostática (Figura 33a), seguindo as recomendações da ABNT NBR 10838 (ABNT, 1988). Os procedimentos adotados para obtenção dos dados necessários para esta etapa da pesquisa foram:

1) Realização de cortes longitudinais (Figura 33b) e cortes transversais (Figura 33c), de modo que as amostras compactadas fossem subdivididas em 12 partes semelhantes (Figura 33d), das quais foram retirados os corpos de prova para a determinação da massa específica; 
2) No decorrer da etapa (1) foram verificadas as distâncias entre as lentes borrifadas com azul de metileno (alturas de cada camada de compactação);

3) Com auxílio de uma faca os corpos de prova foram talhados em formato aproximadamente esféricos (Figura 33e). Ao longo deste processo foram tomadas três amostras para determinação do teor de umidade;

4) A temperatura da água foi verificada por meio de um termômetro para correção da massa específica da água;

5) A massa das amostras foi determinada em 3 condições diferentes: massa ao ar do solo, massa ao ar do solo + parafina, e massa submersa do solo + parafina.

A massa específica da parafina ( $\left.\rho_{\text {par }}\right)$ utilizada nos cálculos foi igual a $0,910 \mathrm{~g} / \mathrm{cm}^{3}$. Este é valor usualmente adotado no laboratório de Geotecnia da EESC. Araújo (1996) utilizou em seus cálculos um valor para massa específica da parafina igual a $0,89 \mathrm{~g} / \mathrm{cm}^{3}$, que por sua vez é próximo ao adotado na presente pesquisa.
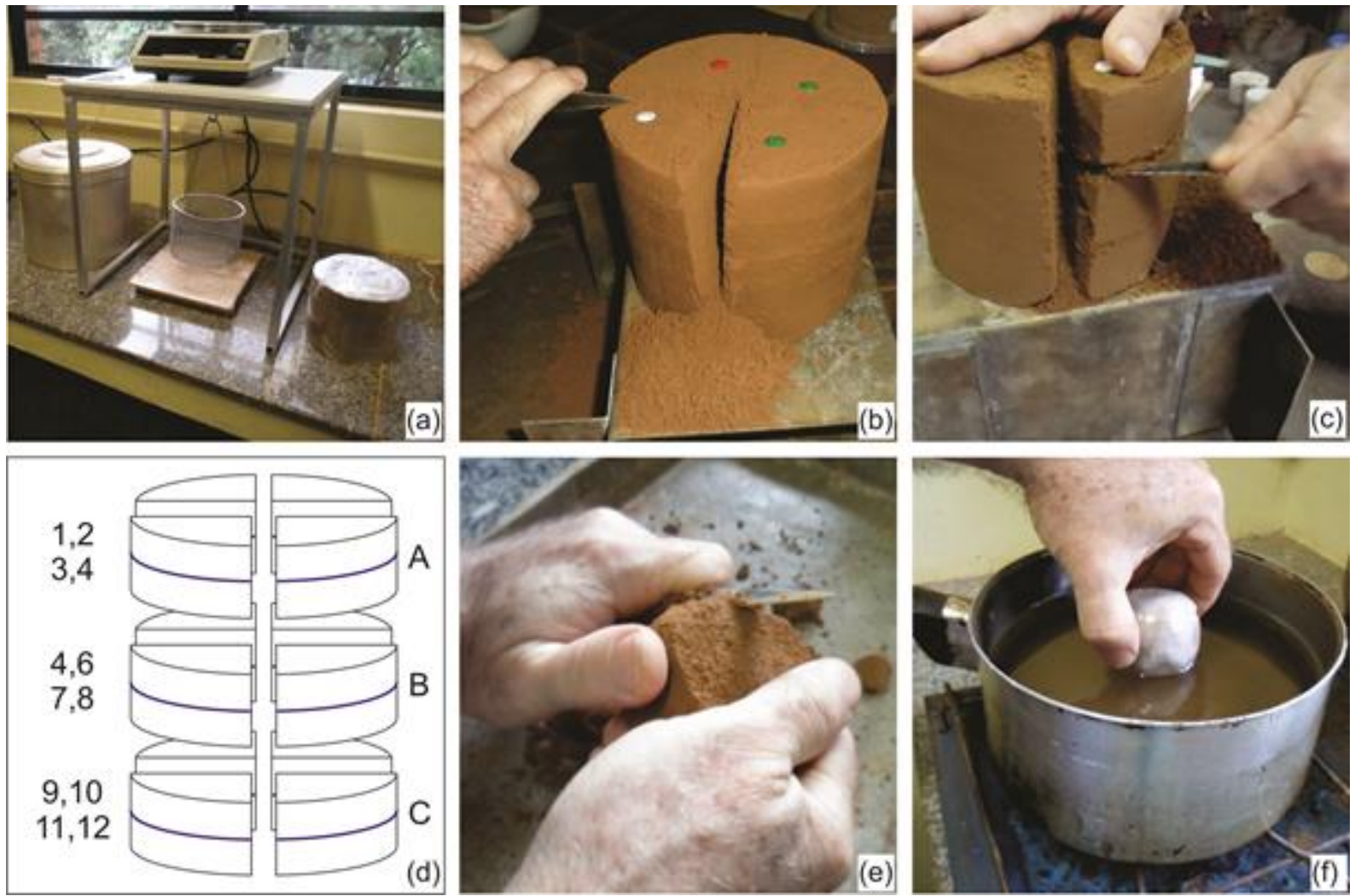

Figura 33 - Ensaio de massa específica do solo pelo método da imersão: (a) equipamentos utilizados; (b) corte longitudinal; (c) corte transversal; (d) disposição e esquema de identificação dos corpos de prova; (e) talhamento dos corpos de prova; (f) imersão em parafina. 
4.5.2 Condutividade hidráulica, compressão triaxial e bender elements

Em função do procedimento de compactação das amostras estabelecido na seção 4.5.1, foi possível realizar a etapa de preparação dos corpos de prova necessários para realização dos ensaios de condutividade hidráulica, compressão triaxial. A Figura 34 ilustra o esquema da direção de talhagem dos corpos de prova moldados tanto na direção vertical $\left(\theta=90^{\circ}\right)$ como na horizontal $\left(\theta=0^{\circ}\right)$ orientados frente ao plano de compactação. As dimensões destes corpos de prova foram de aproximadamente $50 \mathrm{~mm}$ de diâmetro por 100 $\mathrm{mm}$ de altura, de forma a atender a relação altura/diâmetro estabelecida na norma ASTM D4767 (ASTM, 2011a).

(a)

Amostragem ao longo do sentido de compactação

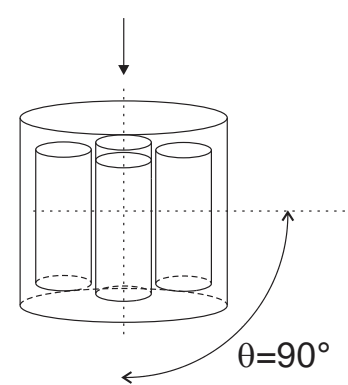

(b)

Amostragem perpendicular ao sentido de compactação

Figura 34 - Sentido da retirada dos corpos de prova cilíndricos logo após a compactação.

Para a talhagem dos corpos de prova utilizados no ensaio com bender elements adotou-se um esquema parecido com o descrito na Figura 34. No entanto, foram talhados dois corpos de prova no sentido vertical $\left(\theta=90^{\circ}\right)$ e mais dois no sentido horizontal $\left(\theta=0^{\circ}\right)$ para cada amostra compactada.

Após a extração da amostra com auxílio de um extrator mecânico, os corpos de prova foram talhados em formatos cilíndricos por meio da utilização de tornos e facas (Figura 35a). Na Figura 35b ilustra a identificação dos corpos de prova e a presença de lentes de azul de metileno, dispostas verticalmente, oriundas do processo de aspersão realizado durante a compactação. 

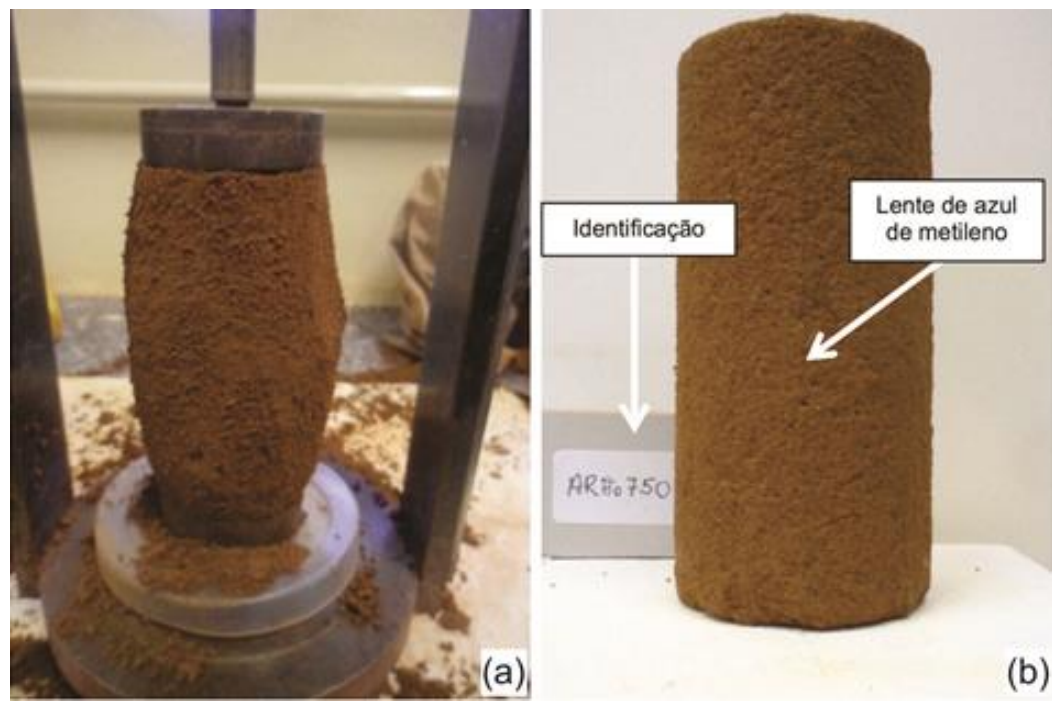

Figura 35 - Corpos de prova cilíndricos: (a) Processo de moldagem dos corpos de prova cilíndricos; (b) após a moldagem na direção horizontal.

\subsubsection{Compressão confinada}

Para os ensaios de compressão confinada empregaram-se amostra que seguiram o mesmo padrão daquelas utilizadas na moldagem dos corpos de prova do ensaio descritos na seção 4.5.2. Nessa etapa, dois corpos de prova de $2,5 \mathrm{~cm}$ de diâmetro e $7,5 \mathrm{~cm}$ de altura foram moldados, sendo um deles na direção vertical $\left(\theta=0^{\circ}\right)$ e outro na direção horizontal $\left(\theta=90^{\circ}\right)$, conforme esquematizado na Figura 36.

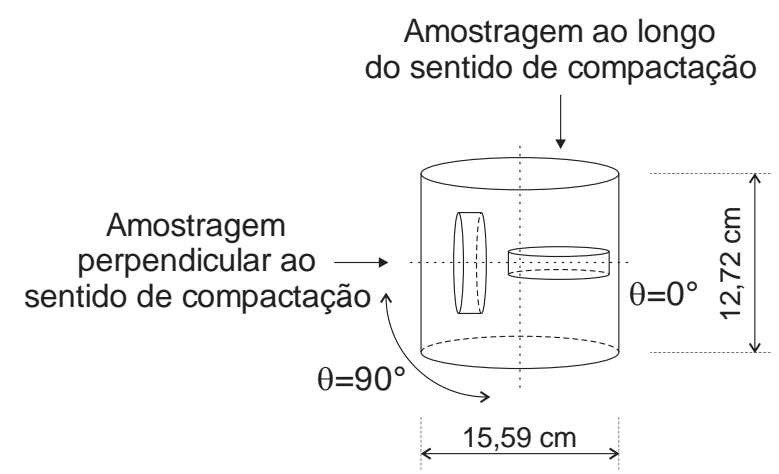

Figura 36 - Sentidos de amostragem nos dois sentidos dos corpos de prova utilizados no ensaio de compressão confinada.

O processo de talhagem dos corpos de prova foi acompanhado da cravação do anel metálico (Figura 37b) até que fosse possível plainar uma de suas faces. Nota-se na Figura 37a que o filme plástico permaneceu presente durante o processo de cravação do anel metálico no intuito de reduzir a perda de água durante o processo. 


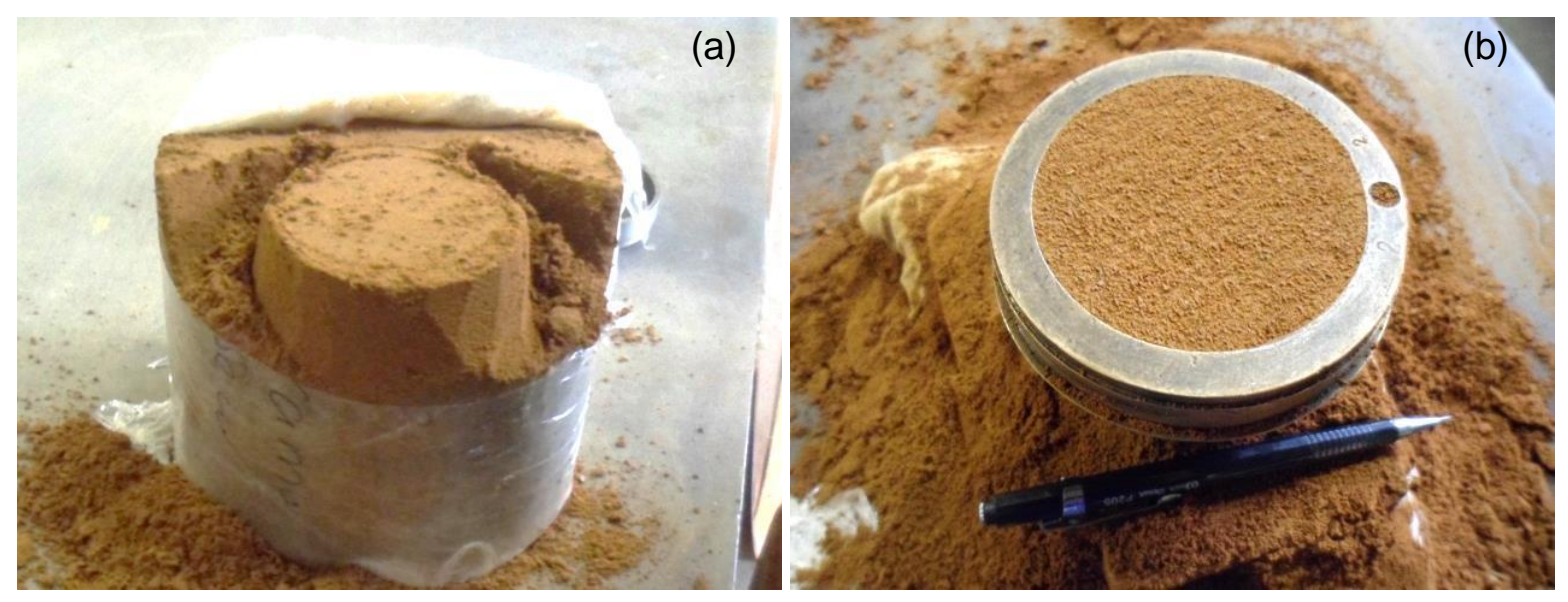

Figura 37 - Moldagem dos corpos de prova para o ensaio de compressão confinada: a) moldagem na direção. horizontal; b) cravação do anel de adensamento na direção vertical.

\subsubsection{Porosimetria por intrusão de mercúrio}

Os ensaios de porosimetria por intrusão de mercúrio foram realizados por meio de corpos de prova moldados no ramo seco, umidade ótima e ramo úmido. A quantidade de solo utilizada durante a compactação foi controlada para que fosse possível obter os índices físicos alvo (Tabela 4). No intuito de reduzir o efeito do gradiente de massa específica seca, optou-se por compactar uma menor quantidade de solo. Para tanto, foi utilizado um molde com $7 \mathrm{~cm}$ de diâmetro com 2,5 cm de altura. Após a compactação, cada corpo de prova foi talhado na direção vertical, até que fosse obtida uma amostra de aproximadamente $1,5 \mathrm{~cm}$ de diâmetro com $2 \mathrm{~cm}$ de altura (Figura 38). Os corpos de prova talhados foram mantidos ao ar livre por um período de sete dias e, então, secos em estufa a uma temperatura de $40^{\circ} \mathrm{C}$ ao longo de dois dias. Após esta etapa, os corpos de prova foram encaminhadas ao IFSC para realização do ensaio de porosimetria por intrusão de mercúrio.

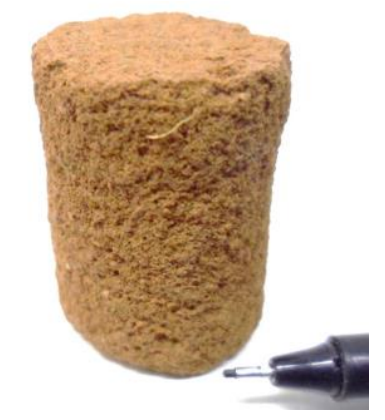

Figura 38 - Corpo de prova moldado para realização do ensaio de porosimetria por intrusão de mercúrio. 


\subsection{Ensaio de compressão confinada}

O ensaio edométrico foi realizado seguindo a norma ABNT NBR 12007 (ABNT, 1990). Para sua realização foram confecionados corpos de prova para representar cada uma das regiões da curva de compactação: o ramo seco, umidade ótima e ramo úmido. Após a moldagem das amostras foram talhados corpos de prova seguindo os procedimentos discriminados na seção 4.5.3. Os corpos de prova foram colocados na prensa de adensamento e em seguida inundados, utilizando água destilada (Figura 39a). Por meio de buretas (Figura 39b) com acesso a parte inferior ao corpo de prova foi possível percolar água por um período de 30 minutos. Após este procedimento, foi aplicado aproximadamente $12,5 \mathrm{kPa}$ e deixado por 24 horas para que fosse possível o pleno encaixe entre a prensa de adensamento e o capacete no topo do corpo de prova.

$\mathrm{Na}$ fase de carregamento os corpos de prova foram submetidos a carregamentos axiais de 25, 50, 100, 200,400, 800, 1600, $3200 \mathrm{kPa}$. No descarregamento as tensões utilizadas foram de $1600,800,400,200,100,50,25$, e $12,5 \mathrm{kPa}$.

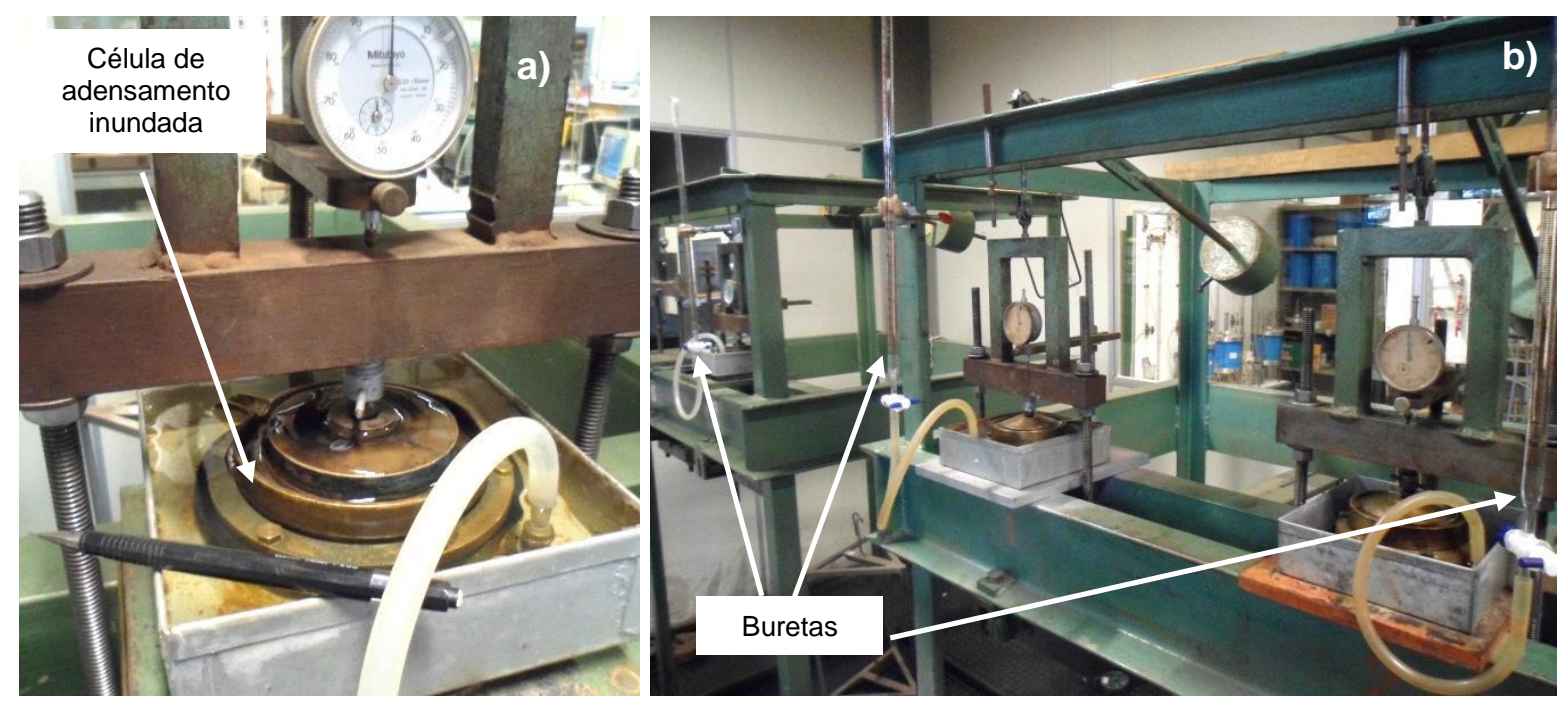

Figura 39 - Ensaio oedométrico: a) posicionamento do corpo de prova na prensa; b) vista dos 3 ensaios em andamento e posicionamento de acesso a bureta na parte inferior ao corpo de prova. 


\subsection{Condutividade hidráulica}

A fase de condutividade hidráulica foi obtida por meio de corpos de prova cilíndricos, talhados conforme especifica a seção 4.5.2. O ensaio de condutividade hidráulica foi realizado logo após a fase de consolidação, e anteriormente à fase de ruptura dos corpos de prova. A condutividade hidráulica obtida para os corpos de prova talhados na direção horizontal e vertical correspondem às condutividades hidráulicas nas direções paralela $\left(k_{h}\right) \mathrm{e}$ ortogonal $\left(k_{v}\right)$ às camadas de compactação, respectivamente.

A fim de garantir maior agilidade durante os ensaios de condutividade hidráulica e compressão triaxial foi elaborado um painel com a função de garantir a percolação e a saturação simultâneas, por contrapressão, de três corpos de prova. Este sistema é composto por válvulas de esfera, reguladores de pressão, mangueiras flexíveis de alta pressão, interface ar/água, transdutor de pressão, manômetro, indicador digital de pressão e bases para apoiar as câmaras triaxiais, conforme ilustra a Figura 40

Previamente a realização dos ensaios de condutividade hidráulica e compressão triaxial, os instrumentos de medidas utilizados foram calibrados conforme as recomendações sugeridas por Head (1998). Além dos instrumentos de medidas, também foram calibradas as variações volumétricas das câmaras, uma vez que durante a fase de consolidação isotrópica as variações volumétricas atribuídas a expansão das câmaras foram abatidas. Previamente a instalação do corpo de prova sobre a câmara triaxial, as válvulas foram saturadas a fim de que as bolhas de ar oclusas fossem eliminadas. Antes de serem inseridas na câmara, as pedras porosas foram previamente fervidas durante 15 minutos. 


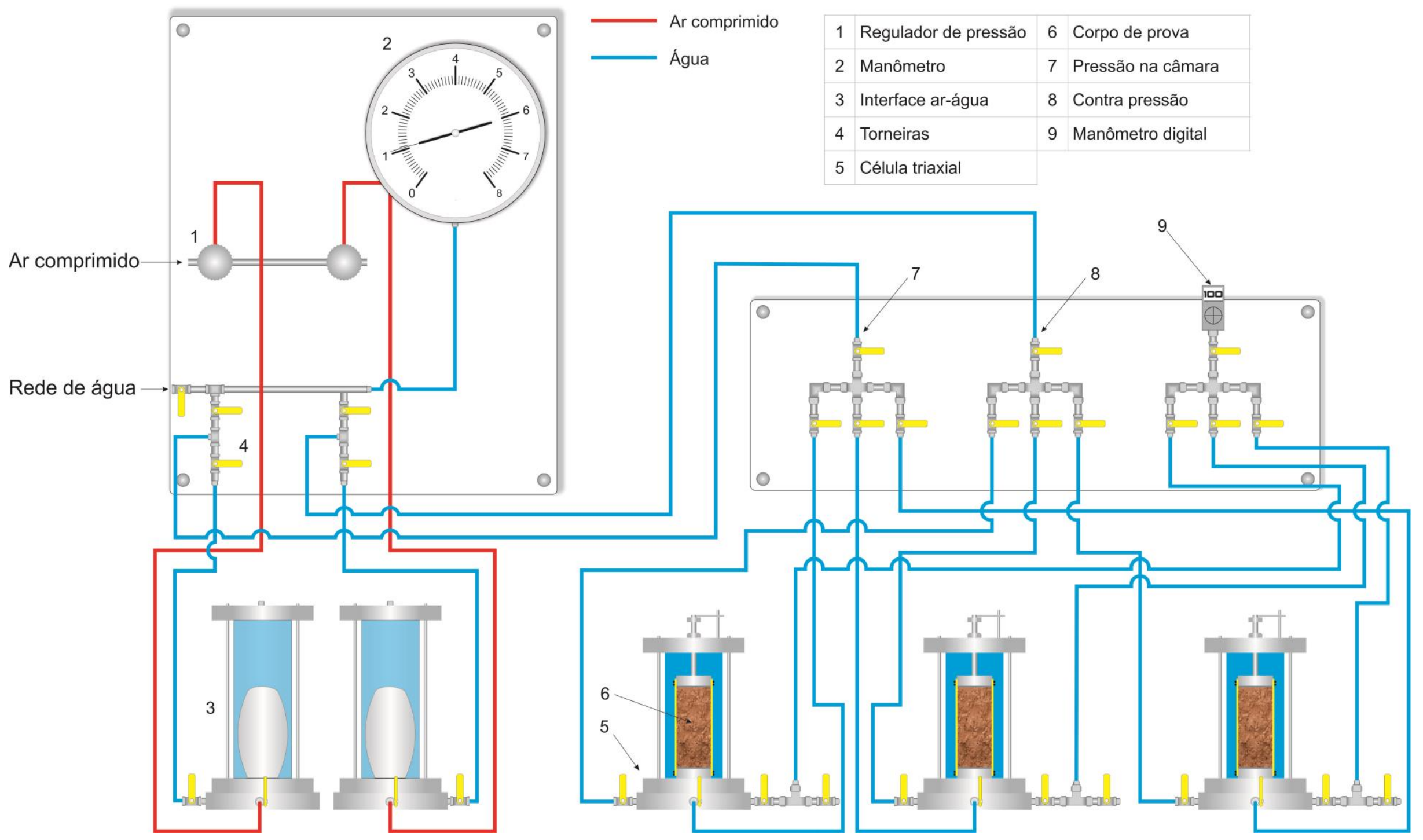

Figura 40 - Esquema utilizado na saturação dos corpos de prova. 
Após a instalação do corpo de prova sobre a base da câmara triaxial, realizou-se a fase de percolação, para permitir a eliminação de parte das bolhas oclusas no solo. Devido às características arenosas do solo analisado, adotou-se como critério de parada um tempo de percolação de água equivalente a 30 minutos, ou até que não se observasse a saída de bolhas de ar. Nesta fase foi utilizado $50 \mathrm{kPa}$ de tensão aplicada na câmara, acompanhada de $40 \mathrm{kPa}$ de contrapressão, mantida por um reservatório elevado (rede de água). A partir desse estágio, foram aplicados incrementos sucessivos de pressão na câmara e na contrapressão iguais a $50 \mathrm{kPa}$. Cada incremento de pressão foi mantido por 3 horas.

O corpo de prova foi considerado saturado quando se obteve um parâmetro $\bar{B}$ maior ou igual a 0,98. O cálculo deste parâmetro foi realizado por meio da Equação 15, proposta por Skempton (1954). Esta equação relaciona a variação de pressão da água intersticial $(\Delta u)$ com o incremento de pressão na câmara gerado $\left(\Delta \sigma_{3}\right)$.

$$
\bar{B}=\frac{\Delta u}{\Delta \sigma_{3}}
$$

A partir do momento que o corpo de prova atendeu o parâmetro $\bar{B}$ estipulado, iniciou-se a fase de consolidação. Nesta etapa do ensaio cada corpo de prova foi tratado de maneira individual, ou seja, mesmo que tenham sido saturados três corpos de prova de maneira simultânea, a tensão de confinamento foi aplicada individualmente em cada corpo de prova.

Para que se registrasse a variação volumétrica durante o ensaio, utilizou-se um variador de volume ligado à válvula de aplicação de pressão na câmara. Esta prática exige que a variação volumétrica total do sistema (câmara + corpo de prova) leve em consideração a expansão volumétrica da própria câmara, a fim de que se conheça a variação volumétrica do corpo de prova. Desse modo, subtraiu-se a variação volumétrica da câmara, daquela atribuída a variação volumétrica total do sistema. Utilizou-se a estabilização volumétrica ao longo do tempo como critério de parada do ensaio. Ao todo, foram empregadas tensões de confinamento de 50, 100, $200 \mathrm{kPa}$.

Após a fase de adensamento, iniciou-se a etapa de condutividade hidráulica por meio do ensaio em permeâmetro de parede flexível à carga constante, seguindo as recomendações da norma ASTM D5084 (ASTM, 2010). A referida norma recomenda que o ensaio seja realizado em solo com valores de condutividade hidráulica inferiores a $10^{-6} \mathrm{~m} / \mathrm{s}$.

Para evitar a movimentação das partículas finas durante a aplicação do fluxo através dos corpos de prova, a ASTM D5084 (ASTM, 2010) recomenda valores de gradientes hidráulicos válidos para um dado intervalo de condutividade hidráulica esperada 
para o material de análise. No caso do solo estudado, utilizou-se o valor de gradiente hidráulico igual a 10, aplicado por meio da diferença de $10 \mathrm{kPa}$ entre a base e o topo do corpo de prova. Enquanto uma fonte de pressão foi responsável pela aplicação da pressão na câmara, as outras duas tiveram como objetivo manter o gradiente hidráulico estipulado. Para que todas as fontes de pressão tenham a mesma referência, optou-se por calibrar os atuadores de pressão com auxílio do mesmo manômetro utilizado nas duas interfaces arágua.

Durante o ensaio monitorou-se o fluxo ascendente no corpo de prova através do mesmo variador de volume utilizado na fase de adensamento. $O$ andamento do ensaio se deu pelo registro da variação de volume a cada 15 minutos, obtidas por meio do Datalog acoplado à prensa de compressão triaxial, a partir do qual, foi possível conhecer o volume de água percolado através do corpo de prova ao longo do tempo.

Ao longo do ensaio, além do monitoramento do volume de água percolado, foi realizado também o registro da variação da temperatura da água. Este procedimento é recomendado pela ASTM D5084 (ASTM, 2010) a fim de corrigir o efeito da variação da temperatura na massa específica da água, e consequentemente no seu volume percolado durante o ensaio. Para tanto, utilizou-se as Equações 16 e 17 no intuito de corrigir a condutividade hidráulica $(k)$ para condutividade hidráulica a temperatura de $20^{\circ} \mathrm{C}\left(k_{20}\right)$.

$k_{20}=R_{T} \times k$

$R_{T}=\frac{2,2902 \times\left(0,9842^{T}\right)}{T^{0,1702}}$

Onde: $k_{20}=$ condutividade hidráulica corrigida para temperatura de $20^{\circ} \mathrm{C} ; R_{T}=$ razão da viscosidade da água utilizada no ensaio para $20^{\circ} \mathrm{C} ; k=$ condutividade hidráulica; $T=$ temperatura média da água durante a aplicação do fluxo.

As amostras ensaiadas foram submetidas a tensões de confinamento de 50, $100 \mathrm{e}$ $200 \mathrm{kPa}$. Após a determinação das condutividades hidráulicas, as amostras foram levadas a ruptura, conforme descrito na seção 4.8 . 


\subsection{Ensaio de compressão triaxial}

Os ensaios de compressão triaxial foram realizados logo após a fase de condutividade hidráulica. Nesta etapa foram utilizadas três câmaras Wykeham Farrance e uma prensa do mesmo fabricante. Durante este ensaio, a força foi aplicada por meio de um pistão com deslocamento constante ao longo do tempo. Para medir a força necessária para reação do sistema utilizou-se um anel dinamométrico acompanhado de um extensômetro previamente calibrado. Tanto a pressão na câmara como a contrapressão foram aplicadas por meio de sistemas de interface ar/água. Foi utilizado um sistema de aquisição de dados digital, possibilitando o acompanhamento em tempo real da força aplicada, da variação de volume, dos deslocamentos e da pressão na água. Na Figura 41 é possível observar alguns dos equipamentos mencionados.

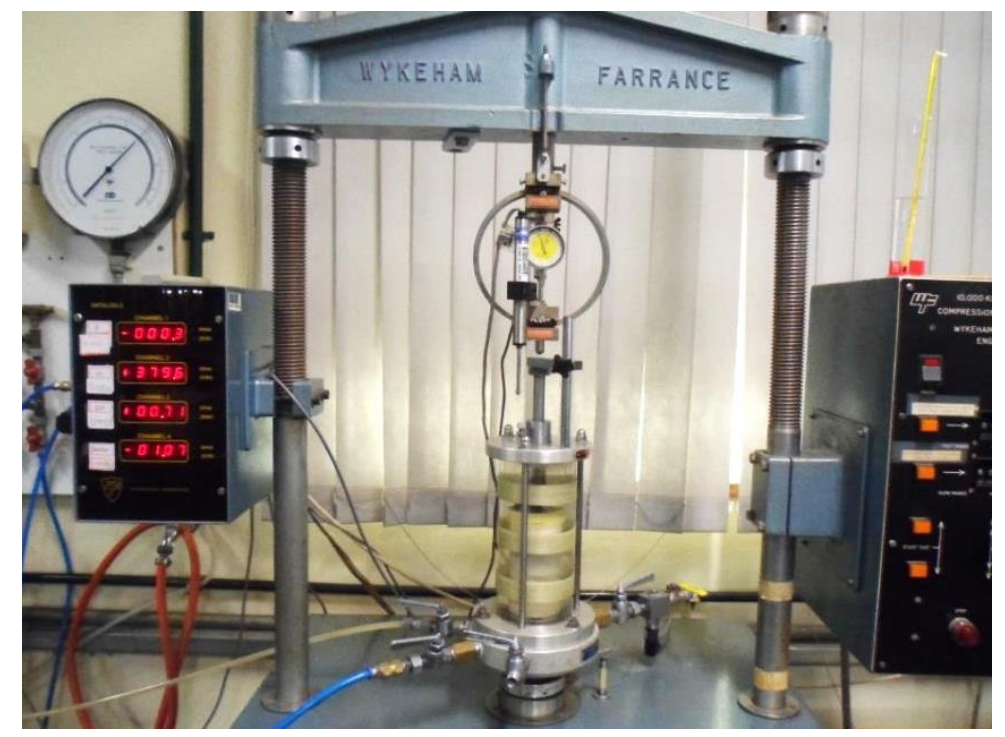

Figura 41 - Equipamentos para ensaios de compressão triaxial.

Todos os ensaios triaxiais realizados na presente pesquisa foram do tipo consolidado não drenado (CU), ou seja, os corpos de prova foram adensados e posteriormente levados a ruptura sem possibilidade de drenagem do corpo de prova, o que propiciou o registro do excesso de pressão da água intersticial por meio de um transdutor de pressão ligado a base da câmara triaxial. Durante o ensaio, cada corpo de prova foi levado à ruptura por incremento da diferença das tensões principais $\left(\sigma_{1}-\sigma_{3}\right)$, mediante à ascensão da câmara a uma velocidade constante ao longo do tempo.

Entretanto, o deslocamento da câmara a uma elevada velocidade, não compatível com o tipo de solo estudado, poderia contribuir para que não houvesse uma plena 
equalização das pressões da água intersticial geradas durante o ensaio, sendo assim, para que evitasse tal situação, utilizaram-se as recomendações de Head (1998) para o cálculo da velocidade máxima a ser usada.

O valor da velocidade de carregamento máxima leva em consideração o tempo despendido para $100 \%$ do adensamento, a altura do corpo de prova e a estimativa da deformação axial na ruptura. Para uma deformação axial da ordem de $8 \%$ e um tempo obtido de 30 minutos para $100 \%$ do adensamento, obteve-se uma velocidade máxima permitida da ordem de $0,5 \mathrm{~mm} / \mathrm{min}$. Desse modo, adotou-se uma velocidade de $0,1 \mathrm{~mm} / \mathrm{min}$, sendo esta inferior à calculada anteriormente e compatível com a prensa utilizada.

Durante os ensaios de compressão triaxial foram realizadas aquisições dos dados de maneira assistida. Registraram-se dados de variação volumétrica ao longo do tempo, força axial, deslocamento e variação da pressão da água intersticial na fase de ruptura. Este programa de aquisição de dados permitiu, em tempo real, o acompanhamento dos resultados obtidos.

Por meio do registro da variação da pressão da água intersticial ao longo da fase de ruptura foi possível calcular os valores das tensões efetivas desenvolvidas no decorrer do ensaio. Utilizou-se como critério de ruptura a diferença máxima das tensões principais $\left(\sigma_{1}-\sigma_{3}\right)$ e o maior valor da relação entre as tensões principais efetivas $\left(\sigma_{1}^{\prime} / \sigma_{3}^{\prime}\right)$. A partir desses critérios obtiveram-se os valores de $s^{\prime}$ e $t$ utilizando as Equação 18 e 19 , respectivamente. Por meio desses valores, realizou-se um ajuste linear, obtendo-se os parâmetros a' e $\alpha^{\prime}$, através da Equação 20.

$$
\begin{aligned}
& s^{\prime}=\frac{\sigma_{1}^{\prime}+\sigma_{3}^{\prime}}{2} \\
& t=\frac{\sigma_{1}^{\prime}-\sigma_{3}^{\prime}}{2}
\end{aligned}
$$

Onde: $\sigma_{1}^{\prime}$ e $\sigma_{3}^{\prime}$ são as tensões principais efetivas maior e menor, respectivamente.

Por meio dos valores de $a^{\prime}$ e $\alpha^{\prime}$ e das Equações 21 e 22 foi possível obter os parâmetros de resistência ao cisalhamento do solo analisado ( $c^{\prime}$ e $\left.\phi^{\prime}\right)$.

$$
\begin{aligned}
& t=a^{\prime}+s^{\prime} \times \tan \alpha \\
& \operatorname{sen} \phi^{\prime}=\tan \alpha \\
& c^{\prime}=\frac{a^{\prime}}{\cos \phi^{\prime}}
\end{aligned}
$$




\subsection{Ensaio com bender elements}

Os ensaios com bender elements foram realizados a fim de avaliar o módulo de cisalhamento máximo para as amostras talhadas na direção vertical $\left(G_{0_{v}}\right)$ e horizontal $\left(G_{0 h}\right)$. Os índices físicos alvo utilizados na compactação de cada amostra podem ser visualizados na Tabela 4, seção 4.5. Para cada amostra compactada foram talhados quatro corpos de prova, sendo dois na direção vertical $\left(\theta=90^{\circ}\right)$ e dois na direção horizontal $\left(\theta=0^{\circ}\right)$. Os ensaios foram realizados em amostras com grau de saturação próximo àquele no momento da compactação, ou seja, em condição não saturada.

Recentemente, Georgetti (2014) em sua pesquisa de doutorado, introduziu o conjunto de pedestal e cabeçote com os bender elements em uma câmara triaxial do tipo Bishop-Wesley, juntamente com um osciloscópio e um sistema de aquisição de dados. Sendo assim, na presente pesquisa foram utilizados os mesmos procedimentos adotados pela referida autora, tais como a preparação dos corpos de prova talhados, os equipamentos e arranjos utilizados e, a interpretação dos resultados obtidos.

Os corpos de prova talhados permaneceram envelopados em filmes de PVC e mantidos em recipiente hermeticamente fechado (Figura 42a), com o intuito reduzir a perda de água antes da realização do ensaio. Foram feitas ranhuras no topo e base dos corpos de prova, simétricas entre si (Figura 42b). Para garantir maior aderência entre os bender elements e o solo, as ranhuras foram preenchidas com graxa de silicone. Estas ranhuras foram feitas de modo que suas dimensões ficassem o mais próximo possível das dimensões dos bender elements.
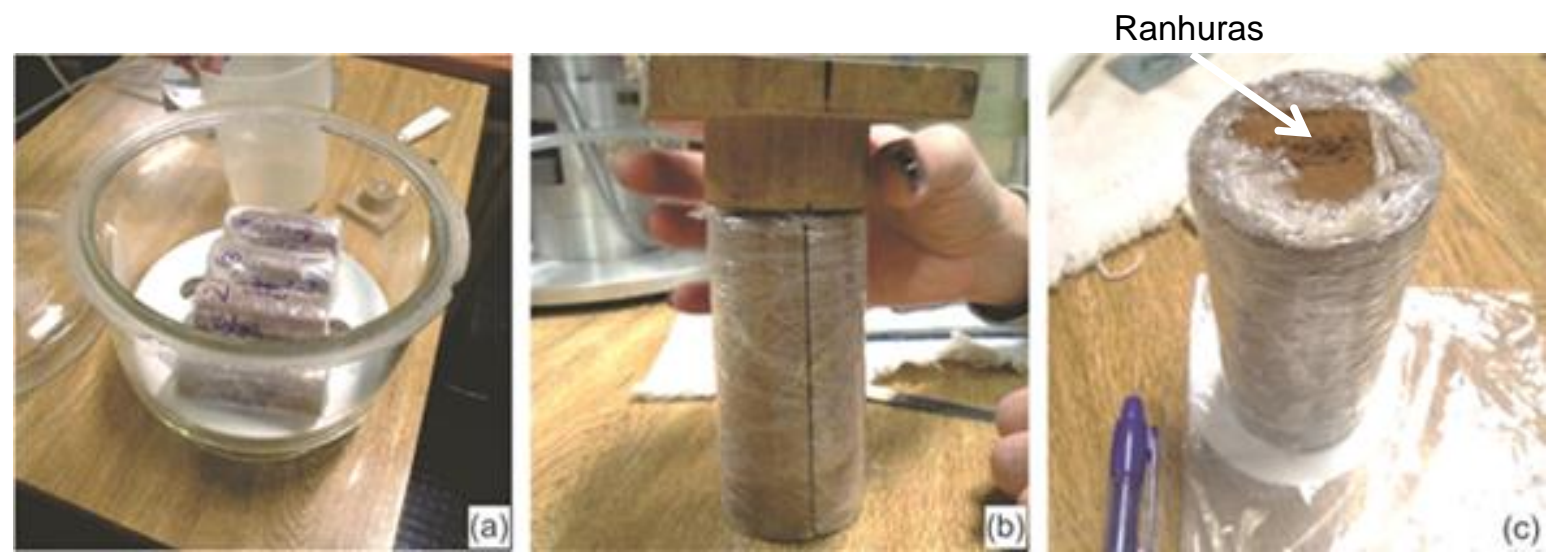

Figura 42 - Preparação das amostras para ensaio com bender elements: (a) armazenamento dos corpos de prova talhados; (b) simetria para execução das ranhuras; (c) ranhura. 
Os ensaios foram realizados com as amostras desconfinadas e sem a instalação de membranas, visto que o objetivo principal desse ensaio foi avaliar apenas a influência da direção de propagação da onda de cisalhamento no solo compactado.

Com o intuito de promover maior aderência entre os bender elements e o solo, optou-se por posicionar uma anilha de $1 \mathrm{~kg}$ sobre o cabeçote superior (Figura 43). Após o posicionamento desta anilha foram aplicados pulsos senoidais de cisalhamento com amplitude de 14 volts e frequências que variaram de 1 a $12,5 \mathrm{kHz}$.

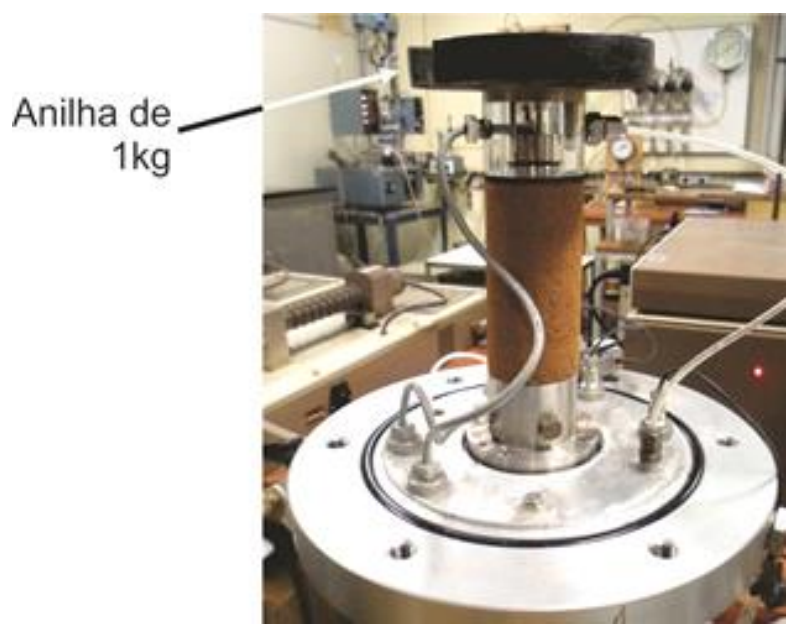

Figura 43 - Corpo de prova instalado e acompanhado de sobrecarga.

Os dados com maior importância na etapa de tratamento dos resultados são a distância percorrida pelo pulso de cisalhamento, o tempo de percurso da onda e a massa específica do corpo de prova. Na determinação da distância percorrida pelo pulso $\left(L_{t t}\right)$, descontou-se o comprimento saliente dos bender elements que penetra no solo, seguindo as recomendações de Viggiani e Atkinson (1995). O tempo de percurso $(t)$ foi obtido pela primeira maior inflexão do sinal recebido (CHAN, 2010; GEORGETTI, 2014), conforme a Figura 44.

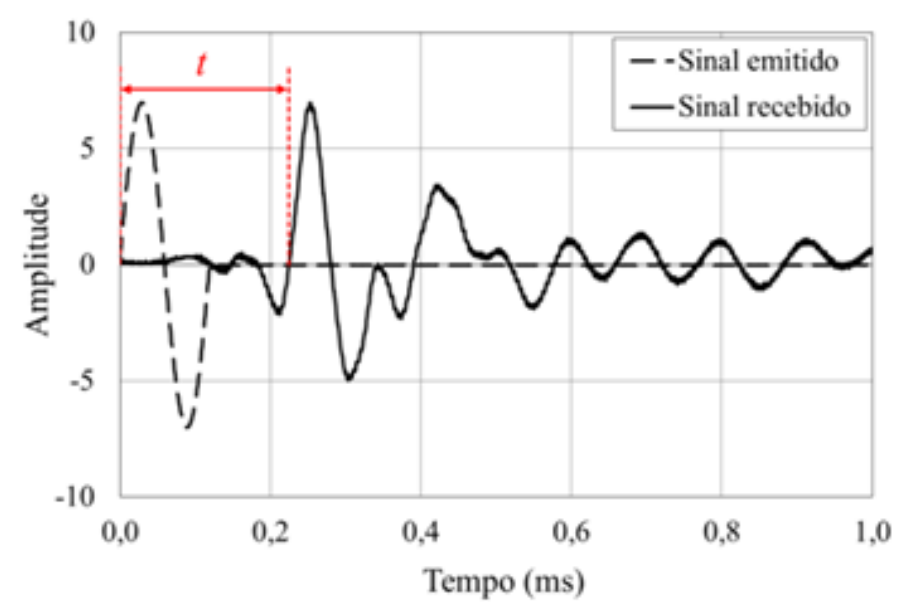

Figura 44 - Determinação do tempo de viagem da onda (GEORGETTI, 2014). 


\section{RESULTADOS E ANÁLISES}

\subsection{Caracterização geotécnica e compactação}

As propriedades dos solos tropicais lateríticos são governadas pelos arranjos, distribuição de grãos e agentes cimentantes (CRUZ; FERREIRA, 1993). A ação cimentante dos óxidos e hidróxidos de ferro promove agregação das partículas finas, fazendo com que em campo se comportem como siltes ou até mesmo areias finais (CAMAPUM DE CARVALHO et al., 1996; ALBUQUERQUE et al., 2006). Esta ação cimentante pode interferir na curva granulométrica do solo, o que pode ser percebido ao alterar o nível de dispersão conferido ao material durante o procedimento de ensaio. Isto motiva a investigação do efeito da dispersão química e física do solo estudado.

Nesta etapa são apresentados os resultados dos ensaios de caracterização geotécnica do solo estudado. Estes resultados são apresentados de forma resumida na Tabela 6. Nela ainda é possível notar o efeito da dispersão química (defloculante) e física (dispersor mecânico) no ensaio de granulometria, na agregação relativa e na classificação final do solo.

Tabela 6 - Propriedades geotécnicas do solo estudado

\begin{tabular}{|c|c|c|c|c|}
\hline Propriedade & Resultado & Resultado $^{(2)}$ & Resultado $^{(3)}$ & Normativa \\
\hline$\rho_{\mathrm{s}}\left(\mathrm{g} / \mathrm{cm}^{3}\right)$ & 2,686 & - & - & NBR 6508 (ABNT, 1984a) \\
\hline$w_{S}(\%)$ & 20,8 & - & - & NBR 7183 (ABNT, 1982) \\
\hline$w_{P}(\%)$ & 22 & - & - & NBR 7180 (ABNT, 1984d) \\
\hline$w_{L}(\%)$ & 33 & - & - & NBR 6459 (ABNT, 1984c) \\
\hline Granulometria & Curva $A^{(1)}$ & Curva $\mathrm{B}^{(2)}$ & Curva $C^{(3)}$ & \multirow{4}{*}{ NBR 7181 (ABNT, 1984b) } \\
\hline Areia (\%) & 59,0 & 61,5 & 83,0 & \\
\hline Silte (\%) & 9,0 & 36,5 & 15,0 & \\
\hline Argila (\%) & 32,0 & 2,0 & 2,0 & \\
\hline $\mathrm{AR}(\%)$ & - & 13,0 & 34,0 & - \\
\hline \multicolumn{4}{|l|}{ Classificação } & \\
\hline USCS & SC & SC & SC & ASTM D2487 (ASTM, 2011a) \\
\hline TRB & $A-6(1)$ & $A-6(1)$ & $A-6(1)$ & ASTM D3282 (ASTM, 2015) \\
\hline
\end{tabular}

${ }^{(1)}$ Com defloculante e com dispersão mecânica; ${ }^{(2)}$ Sem defloculante e com dispersão mecânica;

${ }^{(3)}$ Sem defloculante e sem dispersão mecânica.

A Figura 45 mostra as curvas granulométricas obtidas, denominadas de Curva $A$, Curva $B$ e Curva $C$. Para o ensaio realizado da maneira tradicional (Curva A), observou-se maior presença da fração areia, em torno de $58 \%$, seguido de argila com $32 \%$ e de silte, igual a $9 \%$. Pôde-se observar uma porcentagem de areia em torno de $61,5 \%, 36,5 \%$ de silte 
e $2 \%$ de argila, para a Curva B. Já o ensaio realizado sem a presença de defloculante e sem dispersão mecânica (Curva C), apresentou porcentagem de areia de $83 \%$, cerca de $15 \%$ da fração silte e $2 \%$ de argila, conforme mostra a Tabela 6 . As diferenças observadas entre os métodos de ensaios utilizados demonstram possíveis variações no comportamento do solo em campo e em ensaios de laboratório.

O uso da dispersão mecânica foi capaz de promover a desagregação das partículas de diâmetros próximos ao de areia fina e silte, no entanto, não foi capaz de desagregar os grumos de partículas de argila, conforme Curva B. A amostra que não foi submetida a nenhum tipo de dispersão apresentou uma maior porcentagem de areia fina, acompanhada de elevada descontinuidade na fração silte, Curva C. Convém mencionar que a própria dispersão mecânica nas amostras pode ser suficiente para quebrar a fraca cimentação existente nos solos lateríticos (CRUZ; FERREIRA, 1993).

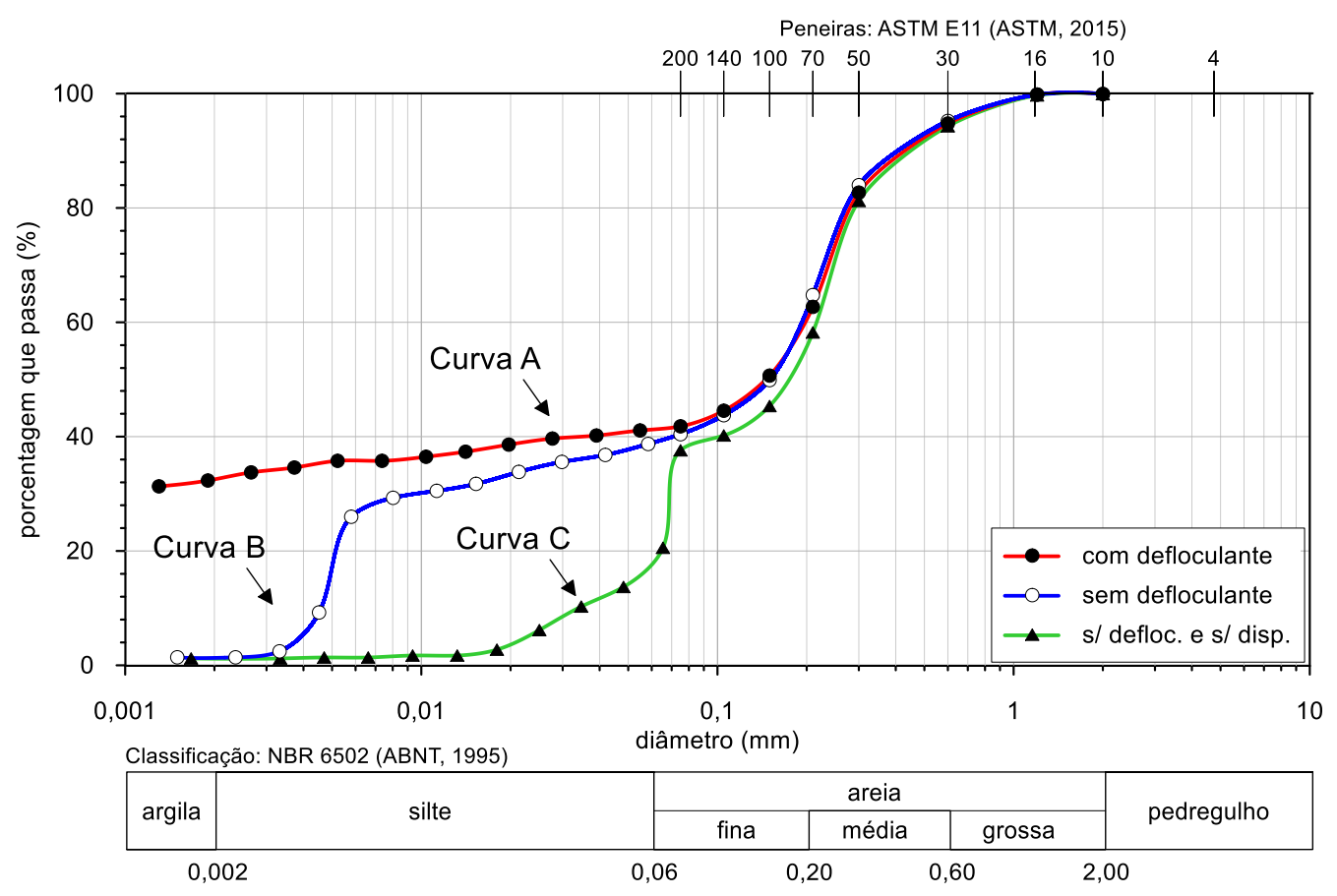

Figura 45 - Análises granulométricas do solo.

Para quantificar as diferenças observadas entre as curvas de distribuição granulométrica, adotou-se o procedimento sugerido por Otálvaro (2013). O referido autor propôs que estas diferenças sejam quantificadas em termos de agregação relativa (AR), conforme Equação 10. Ao aplicar esta equação, as porcentagens de agregações obtidas foram de $13 \%$ e $34 \%$, para as Curva $\mathrm{B}$ e Curva $\mathrm{C}$, respectivamente, quando comparadas à Curva A. Entretanto, Otálvaro (2013) observou uma agregação relativa da ordem de $65 \%$ ao ensaiar uma argila siltosa laterítica, submetida a um procedimento semelhante ao utilizado na Curva $B$, valor aquém do obtido na presente pesquisa. 
As alterações no procedimento de ensaio não foram suficientes para promover variações na classificação do solo, ao aplicar os métodos comumente utilizados na geotecnia, a saber: USCS (Unified Soil Classification System) e TRB (Transportation Research Board). Convém destacar que segundo a TRB o solo analisado foi classificado como A-6(1), o que inviabiliza sua aplicação como material de construção de base para corpo de aterro rodoviário. Entretanto, sabe-se que tanto a classificação USCS como a TRB foram elaboradas por meio de solos formados em climas temperados, portanto, não levam em consideração as propriedades lateríticas do solo.

Além dos ensaios de caracterização, também foi realizado 0 ensaio de compactação na energia Proctor Normal que seguiu as especificações da ABNT NBR 7182 (ABNT, 1986). A curva de compactação foi obtida a partir de 9 corpos de prova, fornecendo como resultado uma massa específica seca máxima de $1,780 \mathrm{~g} / \mathrm{cm}^{3}$ e teor de umidade ótimo de 15,5\%. Estes resultados foram próximos àqueles obtidos em trabalhos anteriores com o solo coletado na mesma região (SILVA, 1996; ARAÚJO, 1996; AQUINO FILHO, 1995; GEORGETTI, 2010 e 2015). Solos lateríticos compactados apresentam certa peculiaridade quanto ao formato da curva de compactação quando comparados a solos não lateríticos. Pinto (2006) observou no ramo seco da curva de compactação de solos lateríticos uma elevada variação de massa específica seca acompanhada de uma pequena variação de teor de umidade, o que faz com que esse trecho seja mais íngreme do que o mesmo trecho (ramo seco) de curvas de compactação características de solos de climas temperados. Ilustra-se na Figura 46 a curva de compactação do solo estudado, onde sua representação condiz com o relatado por Pinto (2006).

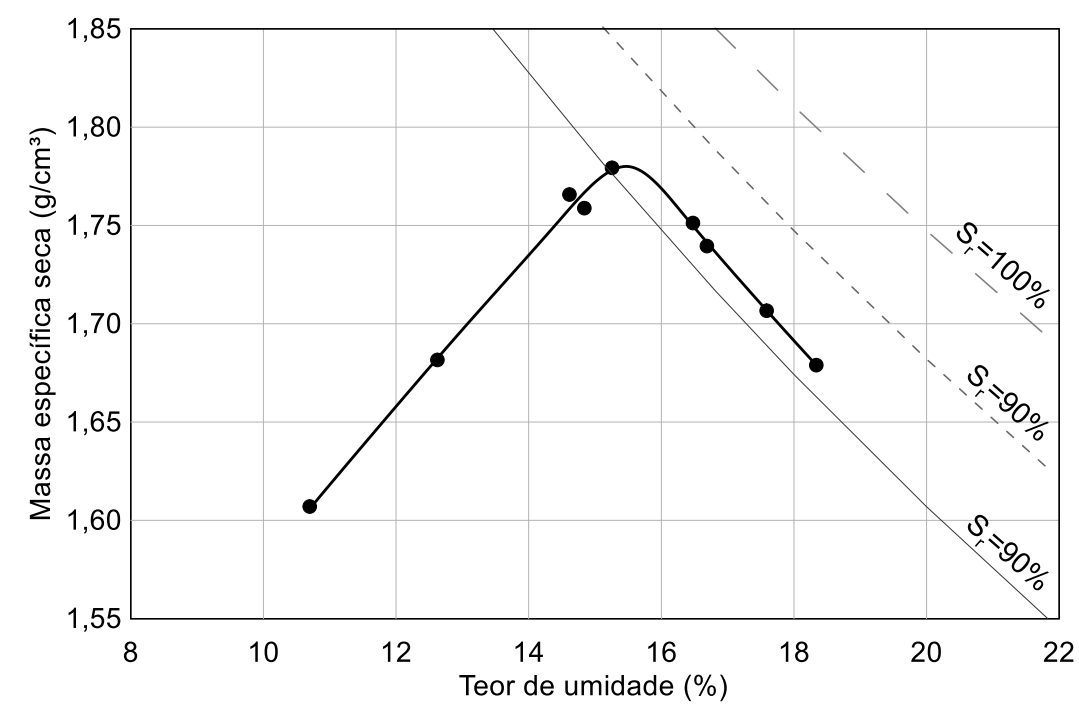

Figura 46 - Curva de compactação. 


\subsubsection{Classificação geotécnica MCT}

O uso das classificações desenvolvidas para solos formados em clima temperado (TRB e USCS) pode causar erros na escolha preliminar de solos típicos de climas tropicais úmidos e, promover a recusa de materiais de alta qualidade por não se adequarem a limites prescritos por normas americanas. A utilização inadequada desta classificação para fins rodoviários, baseada nos limites de consistência e curva granulométrica pode promover sérios problemas geotécnicos, superados com a criação da sistemática MCT (VILLIBOR; NOGAMI, 2009).

Apresentam-se os resultados referentes ao traçado das curvas geradas a partir da sistemática MCT, e os coeficientes obtidos. O coeficiente $c$ foi determinado em função das curvas apresentadas na Figura 47. A sua determinação se deu por meio da curva do afundamento para o teor de umidade de $15,35 \%$, devido à sua maior proximidade ao ponto de coordenada Mini-MCV igual a 10 (abscissa) e diferença de altura igual a $2 \mathrm{~mm}$ (ordenada).

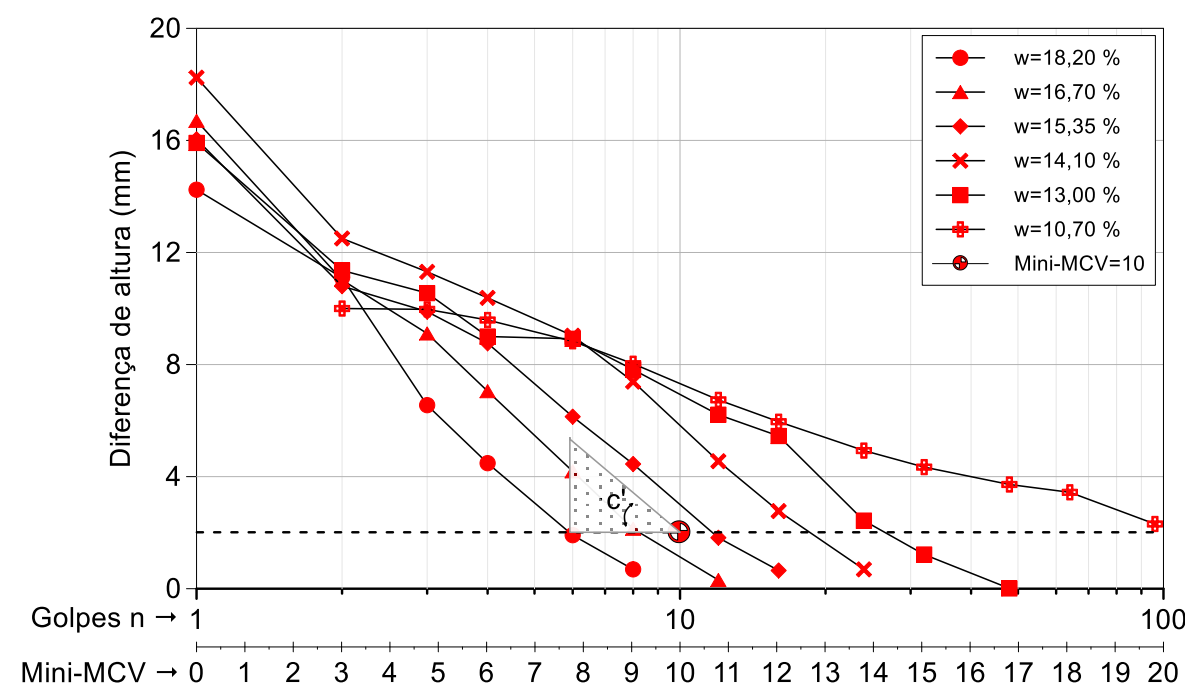

Figura 47 - Curvas de diferença de altura em função do número de golpes (determinação de $c^{\prime}$ ).

Na Figura 48 é possível visualizar as famílias de curvas de compactação. A partir destas, determinou-se o coeficiente $d$ ' através da maior inclinação no ramo seco da curva de compactação para 12 golpes. Este coeficiente indica a argilosidade do solo. 


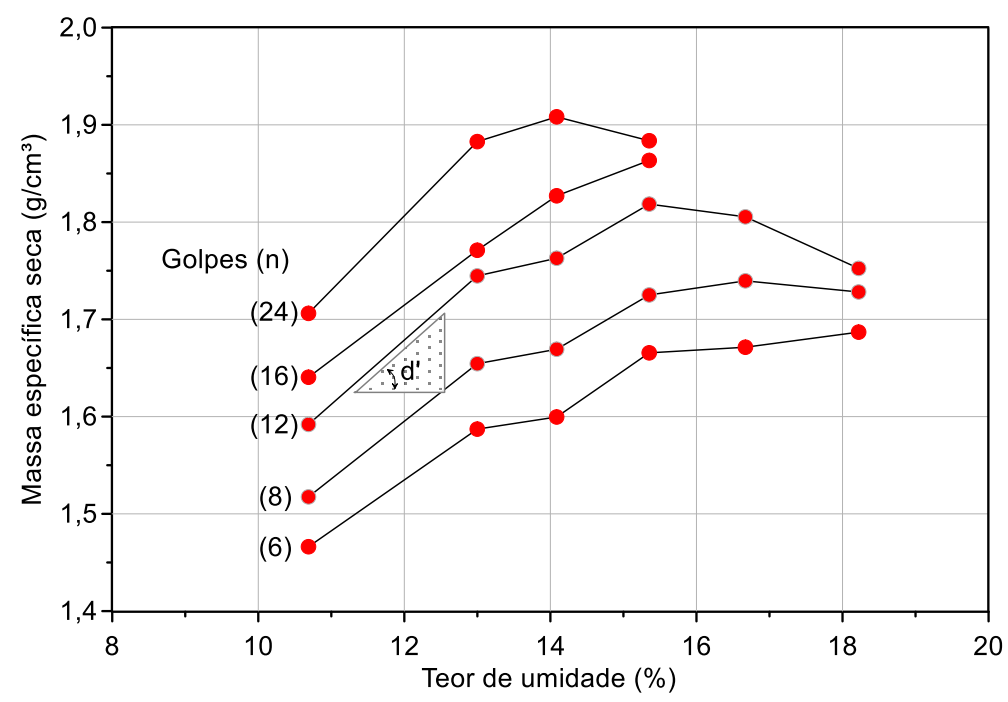

Figura 48 - Curva de compactação com o número de golpes para cada teor de umidade ensaiado (determinação d).

A perda de massa por imersão $\left(P_{i}\right)$ é a porcentagem seca de massa desprendida do corpo de prova quando imerso em água. A Figura 49 mostra os resultados obtidos com a perda de massa por imersão em função dos resultados de Mini-MCV. Tem-se como resultado do ensaio o valor de $P_{i}$ referente ao Mini-MCV igual a 15.

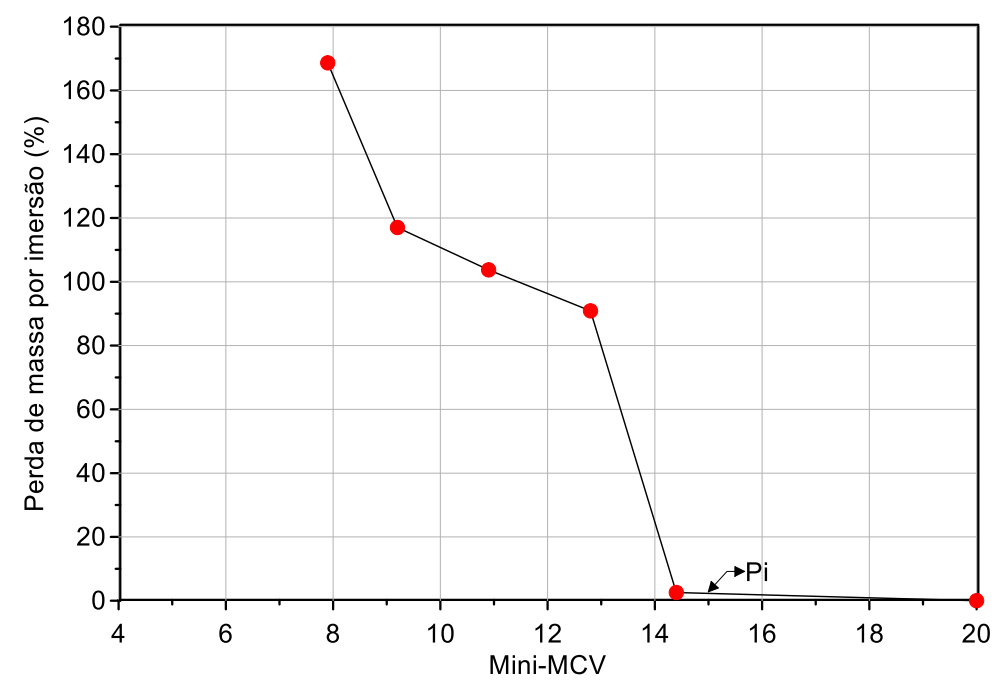

Figura 49 - Curva de perda de massa por imersão em função do MiniMCV (Determinação do PI).

Por meio dos valores de $d$ ' e $P_{i}$, calcula-se o valor do índice $e$, que por sua vez, está intimamente ligado ao grau de laterização do solo. Com o índice $e^{\prime}$ e o coeficiente $c$ ', o solo estudado foi classificado como laterítico arenoso, LA' (Figura 50) 


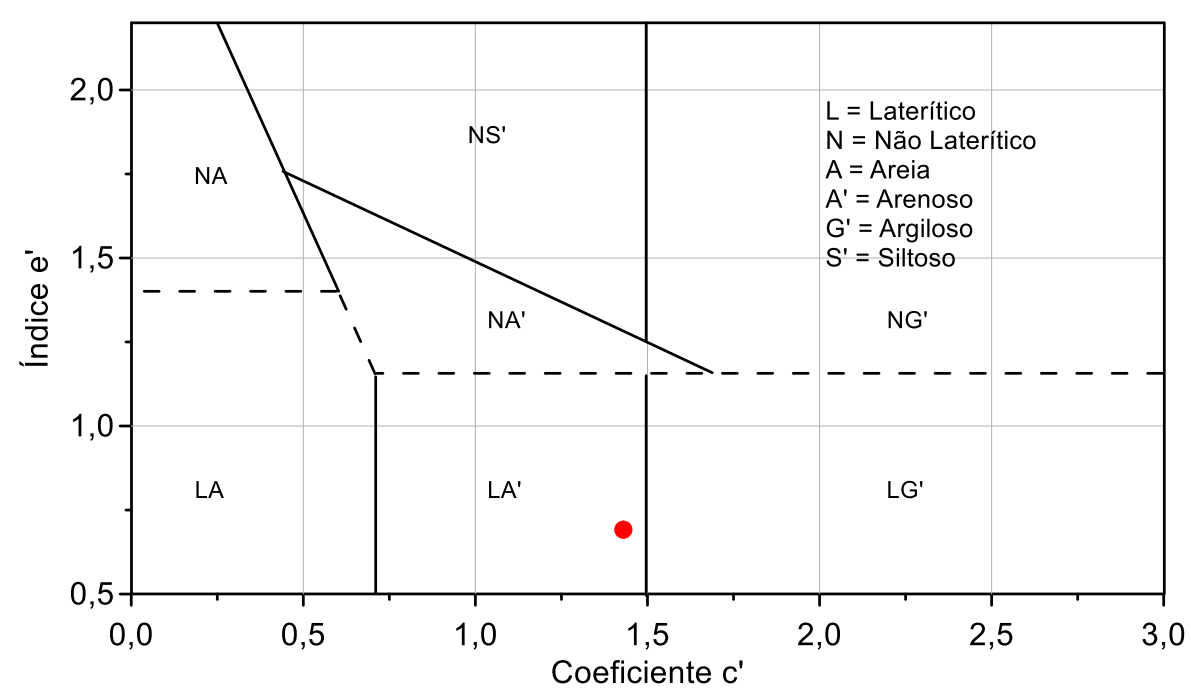

Figura 50 - Posição do solo no gráfico da classificação da MCT.

A Tabela 7 revela os coeficientes e índices necessários para classificação do solo utilizando a sistemática MCT. Por pertencer ao grupo de solos arenosos lateríticos, o solo analisado manifesta-se eficaz para o emprego na construção de bases de pavimento, regularização do subleito, corpo de aterro compactado, revestimento primário e até como proteção à erosão (PERSONS, 1970; GIDIGASU, 1976; VILLIBOR; NOGAMI, 2009). Entretanto, mediante a classificação TRB este solo não seria recomendado na construção de aterros rodoviários, por exemplo. Este fato revela certa ineficácia das tradicionais classificações de solos e evidencia a necessidade de gerar informações que proporcione a correta classificação dos solos tropicais brasileiros, principalmente para sua aplicação em pavimentos econômicos (VILLIBOR; NOGAMI, 2009).

Tabela 7 - Resultados dos ensaios da metologia MCT

\begin{tabular}{cccccc}
\hline$c^{\prime}$ & $d^{\prime}$ & $\operatorname{Pi}(\%)$ & $e^{\prime}$ & Grupo & Classificação \\
\hline 1,43 & 66,5 & 3 & 0,69 & LA' $^{\prime}$ & Laterítico arenoso \\
\hline
\end{tabular}

\subsection{Caracterização físico-química e mineralógica}

As propriedades hidráulicas e mecânicas de solos tropicais estão diretamente associadas ao arranjo estrutural e a composição químico-mineralógica que possuem. A mineralogia é um dos principais fatores que controla o tamanho e as propriedades físicas e químicas das partículas (CAMAPUM DE CARVALHO et al., 2015). Em solos residuais, o estudo da mineralogia do solo é um mecanismo bastante útil na avaliação da ação intempérica da rocha em campo. Por isso, a identificação dos minerais presentes no solo 
torna-se um elemento fundamental na sua correta classificação. A caracterização físicoquímica e mineralógica do solo estudado foi realizada por meio do ensaio de azul de metileno e a difração de raios- $X$.

5.2.1 Capacidade de troca catiônica (CTC)

A técnica de azul de metileno propicia uma boa caracterização da fração fina de solos tropicais. Os ensaios de adsorção de azul de metileno foram realizados com três diferentes quantidades de massa seca. Observa-se na Tabela 8 que a quantidade de solo não interferiu na classificação do material. Quanto à atividade do argilomineral presente na fração argila, os resultados indicaram caráter inativo. Segundo Pejon (1992) a reduzida capacidade de troca catiônica é um indicativo da presença de caulinita e os baixos valores de $V_{b}$ são indicativos de possível comportamento laterítico.

Tabela 8 - Resultados do ensaio de azul de metileno

\begin{tabular}{cccc}
\hline Parâmetro & 1 & 2 & 3 \\
\hline Massa seca $(\mathrm{g})$ & 0,90 & 1,66 & 3,54 \\
CTC (meq/100g) & 4,99 & 4,60 & 4,86 \\
$V b(\mathrm{~g} / 100 \mathrm{~g})$ & 1,60 & 1,47 & 1,55 \\
Acb $(\mathrm{g} / 100 \mathrm{~g})$ & 2,04 & 1,89 & 1,99 \\
SE $\left(\mathrm{m}^{2} / \mathrm{g}\right)$ & 38,90 & 35,99 & 38,00 \\
\cline { 2 - 4 } Argilomineral mais provável & \multicolumn{3}{c}{$95 \%$ caulinita e 5\% ilita } \\
Atividade & \multicolumn{4}{c}{ Inativa } \\
Comportamento laterítico & \multicolumn{4}{c}{} \\
\hline
\end{tabular}

\subsubsection{Difração de Raios-X (DRX)}

A difração de raios- $X$ fornecem informações de aplicação direta na identificação dos minerais presentes no solo. As Figuras 51, 52 e 53 apresentam os difratogramas de raios- $\mathrm{X}$, acompanhado dos possíveis minerais existentes na fração fina do solo estudado. 


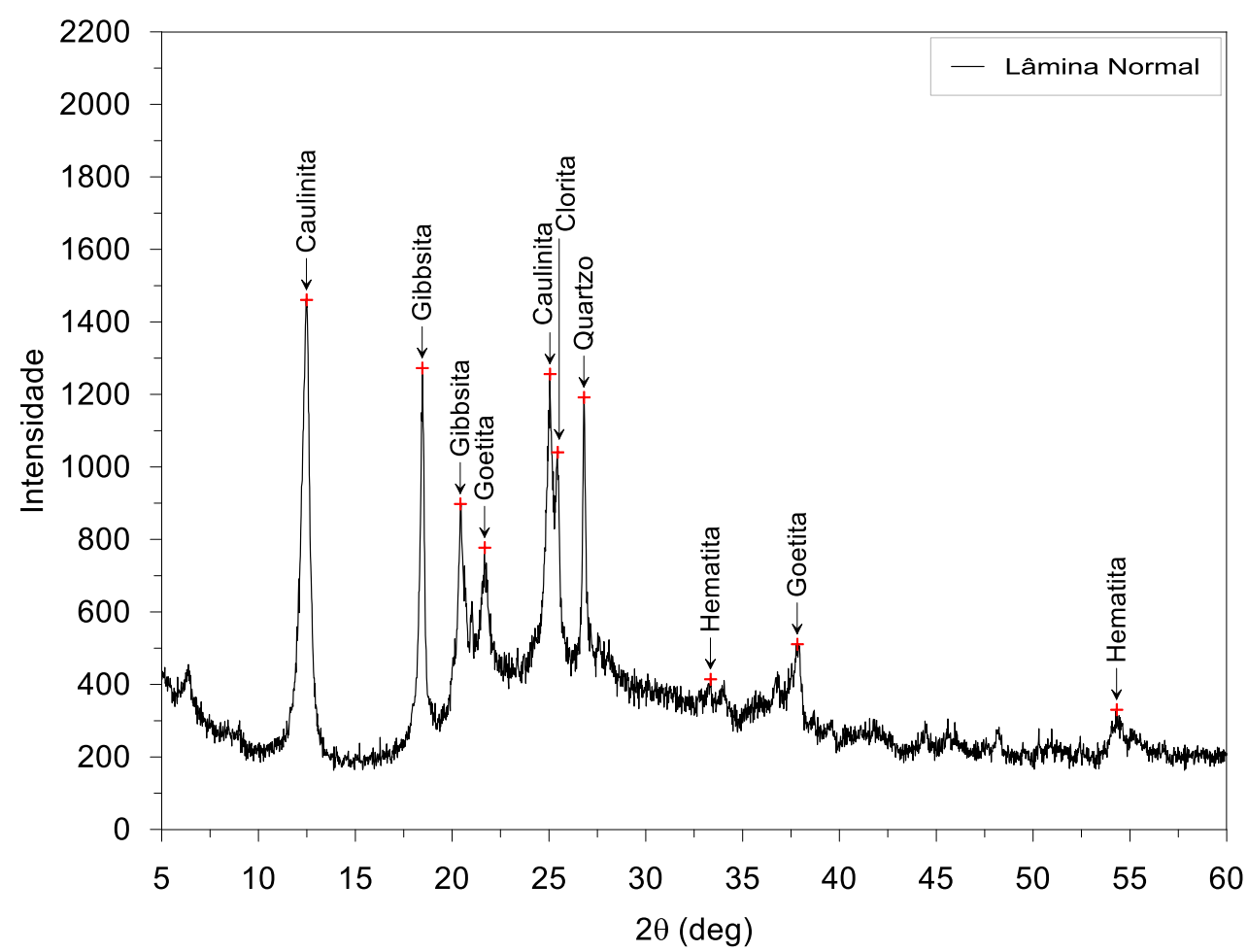

Figura 51 - Difratograma de raio-X para a lâmina normal.

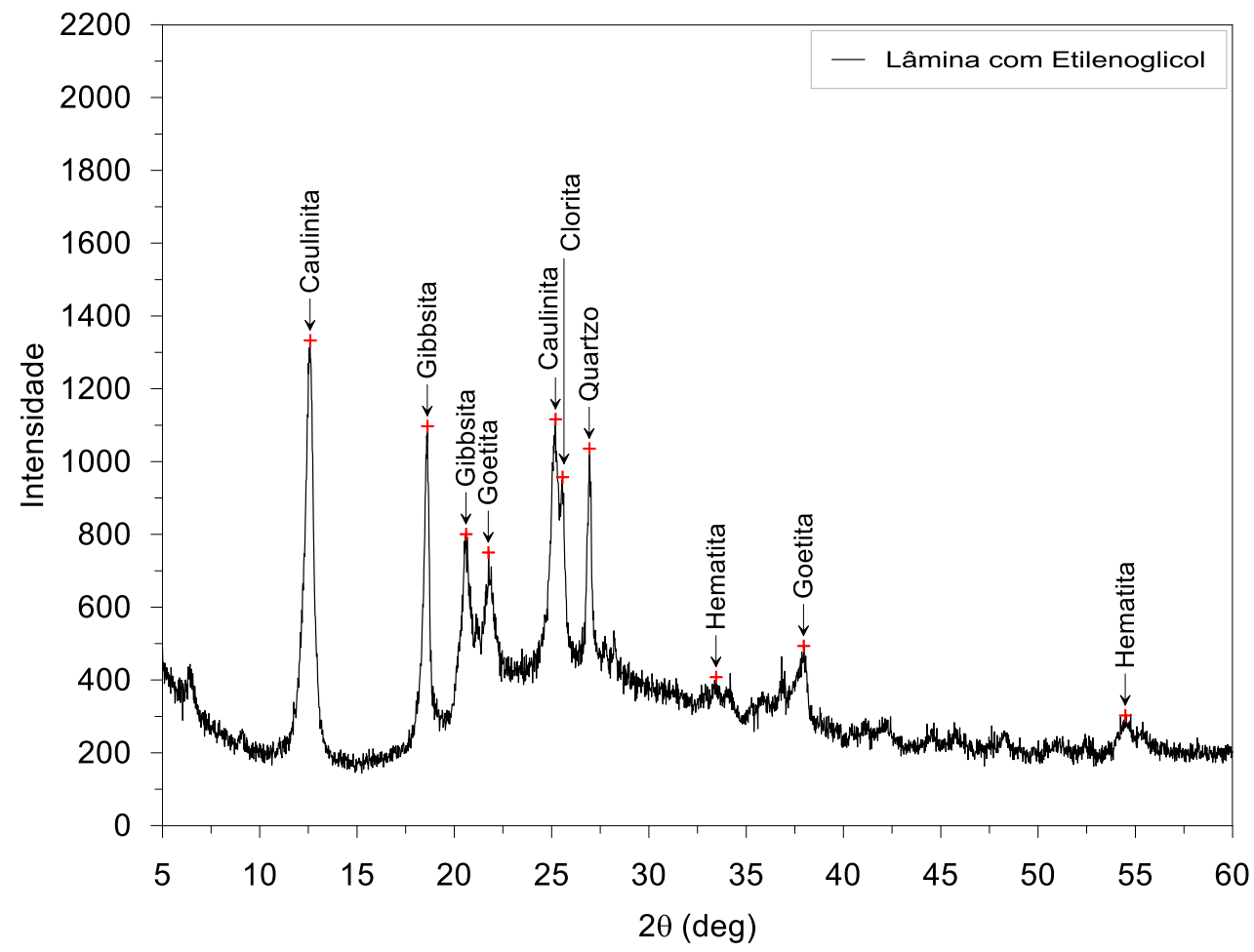

Figura 52 - Difratograma de raio-X para a lâmina tratada com etilenoglicol. 


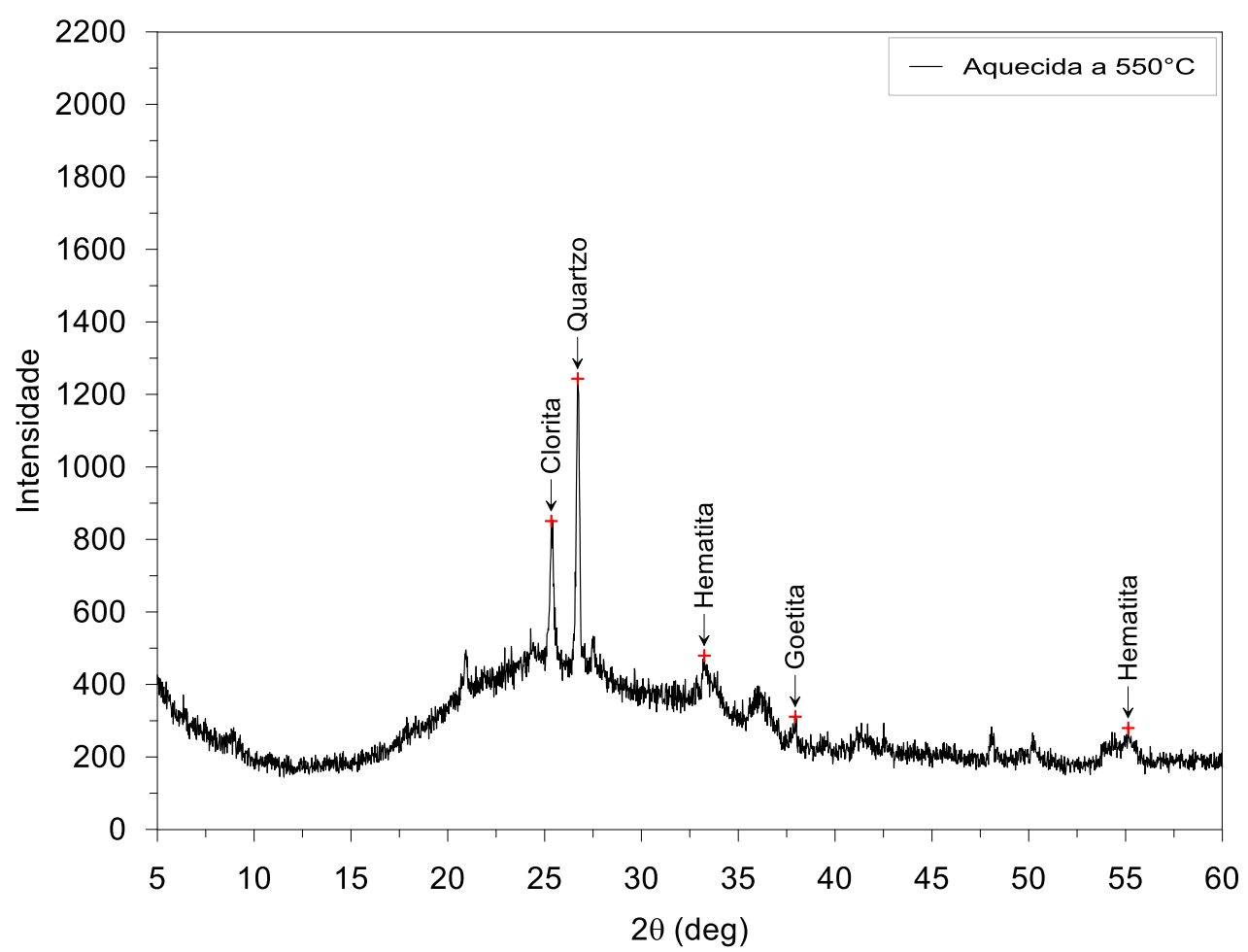

Figura 53 - Difratograma de raio-X para a lâmina aquecida a $550^{\circ} \mathrm{C}$.

Nota-se que não houve variações significativas entre as lâminas sem tratamento e as lâminas tratadas com etilenoglicol, indicando a ausência de argilominerais expansivos. $O$ aquecimento da lâmina promoveu a quebra da estrutura típica de minerais como a gibbsita e caulinita.

A partir deste ensaio identificaram-se os seguintes minerais: caulinita, gibbisita, goethita, clorita, quartzo e hematita. Com exceção da clorita, os demais minerais são típicos de solos com comportamento laterítico. Entretanto, o ensaio de azul de metileno revela uma capacidade de troca catiônica aproximada de $5 \mathrm{meq} / 100 \mathrm{~g}$, aquém do esperado para solos com a presença de clorita, que comumente varia entre 10 e 40 meq/100g (RAIJ, 1969; CAMAPUM DE CARVALHO et al, 2015). Em outras palavras, por mais se tenha observado indícios da presença de clorita, esse mineral parece não governar o desempenho do solo estudado.

A identificação do mineral quartzo na fração silte mais argila é corriqueira nos solos lateríticos (VILLIBOR; NOGAMI, 2009). Os referidos autores comentam que nestes solos a fração silte, quase que em sua totalidade, contam com a presença de quartzo, magnetita e ilmenita.

Por mais que não sejam predominantes na composição, a presença de óxidos e hidróxidos de ferro e alumínio interfere diretamente na estrutura e no comportamento hidromecânico de solos tropicais (CAMAPUM DE CARVALHO et al., 2015). A presença de sesquióxidos, tais como gibbsita evidencia o processo pedogenético sofrido pelo solo. Além 
disso, a existência de minerais como a caulinita (silicato de alumínio hidratado) e a hematita (como representante dos óxidos de ferro presentes no solo) também são indícios de solos bem evoluídos. Convém mencionar que as relações entre óxidos de ferro e caulinita são importantes nas definições das propriedades físicas e nas agregações existentes em solos tropicais (MELO; WYPYCH, 2009). Estas interações influem diretamente no mecanismo de plastificação do solo e, na distribuição dos poros que o constituem (CARDOSO, 2002).

\subsection{Estrutura do solo compactado}

Além da mineralogia, a disposição e o formato das partículas interferem diretamente nas propriedades hidráulicas e mecânicas do solo compactado. Para analisar a estrutura do solo recorreu-se ao ensaio de porosimetria por intrusão de mercúrio que teve por objetivo avaliar o efeito do teor de umidade de compactação na distribuição dos poros da amostra. Realizou-se o ensaio de porosimetria nas amostras compactadas no ramo seco, umidade ótima e ramo úmido a partir dos índices físicos alvo, indicados na Tabela 4, seção 4.5. Por meio desta técnica foi possível quantificar a distribuição e a dimensão dos poros e assim, avaliar o comportamento estrutural do solo em função das condições impostas durante a compactação.

A Figura 54 mostra as distribuições de poros das amostras nas três condições estudadas (ramo seco, umidade ótima e ramo úmido). Considerou-se como tamanho limite entre macroporos e microporos o valor de 0,3 $\mu \mathrm{m}$ (ROMERO, 1999). Nota-se que a distribuição dos tamanhos dos poros é claramente bimodal, típico de solos compactados.

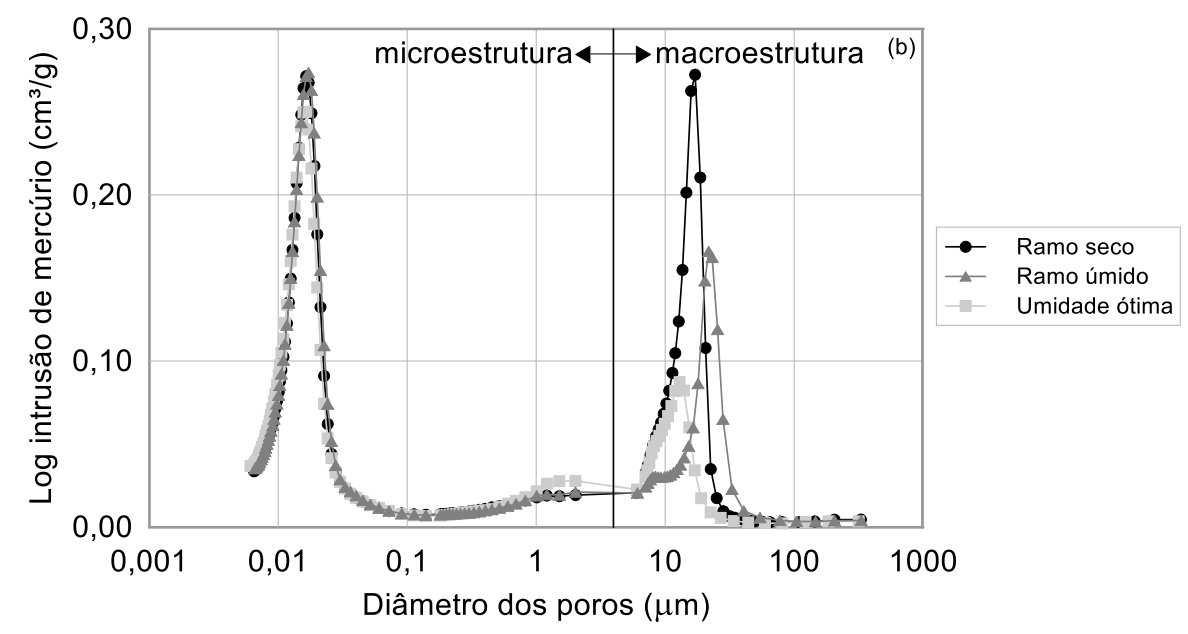

Figura 54 - Porosimetria do solo compactado em diferentes condições. 
Observa-se que os microporos permanecem praticamente constantes nos corpos de prova ensaiados, sendo possível constatar maior presença de poros com tamanho de $0,016 \mu \mathrm{m}$. Ou seja, independente do teor de umidade de compactação, os microporos não são afetados. Por outro lado, observa-se alguma alteração do tamanho e da intensidade dos macroporos, a depender da condição de umidade no momento da compactação. Com relação ao tamanho médio dos macroporos, o correspondente à umidade ótima apresentou o menor valor, $15 \mu \mathrm{m}$, seguido do correspondente ao ramo seco, $17 \mu \mathrm{m}$ e por fim o relativo ao ramo úmido $23 \mu \mathrm{m}$. Nota-se que as diferenças entre os tamanhos dos macroporos foram pequenas, entretanto, observa-se um pico com maior intensidade no ramo seco e menor na umidade ótima. A maior quantidade de macroporos no ramo seco (maior intensidade) pode estar associada à formação da sua estrutura durante a compactação. A elevada resistência dos agregados, ocasionada pelo baixo teor de umidade durante a compactação, contribuiu para uma maior presença de macroporos. O corpo de prova correspondente ao ramo úmido apresentou tamanho de poros intermediário dentre as amostras analisadas.

Por fim, acredita-se que as amostras analisadas não apresentam estruturas tipicamente orientadas, visto a presença de macroporos ao longo da curva de compactação.

\subsection{Influência do número de camadas no gradiente da massa específica seca das amostras}

A estrutura induzida no solo compactado é diretamente relacionada ao método empregado durante a compactação (LAMBE, 1958). Para garantir boa representatividade dos parâmetros geotécnicos em solos compactados em laboratório é indispensável que a amostra seja a mais uniforme possível. A fim de garantir maior homogeneidade nos corpos de prova utilizados na presente pesquisa, optou-se por estudar a influência do número de camadas na uniformidade da amostra compactada, com emprego da balança hidrostática. As amostras foram compactadas com teor de umidade ótimo e massa específica seca máxima, considerando diferentes números de camadas e espessuras, conforme indicado na Tabela 5, seção 4.5.1.

A Figura 55 mostra o grau de compactação, a massa específica seca máxima e o coeficiente de variação no ponto médio de cada uma das três regiões da amostra compactada (base, centro e topo), conforme descrito na seção 4.5.1. Observa-se na Figura 55 a influência do número de camadas de compactação nos valores da massa específica seca. Nas amostras compactadas com camadas de mesma espessura, os gradientes de massa específica seca seguem tendências relativamente similares, independente do número de camadas. Nessa modalidade de compactação, as amostras apresentaram 
massa específica seca máxima menor no topo e maior na base. Este comportamento revela a má distribuição da energia aplicada ao longo da amostra e vai ao encontro dos resultados experimentais divulgados por diversos autores como: Barata (1965), Ladd (1978), Camapum de Carvalho, Mieussens e Carvalho (1985), Lins (1990), Ng e Yung (2008), Aguiar (2010).

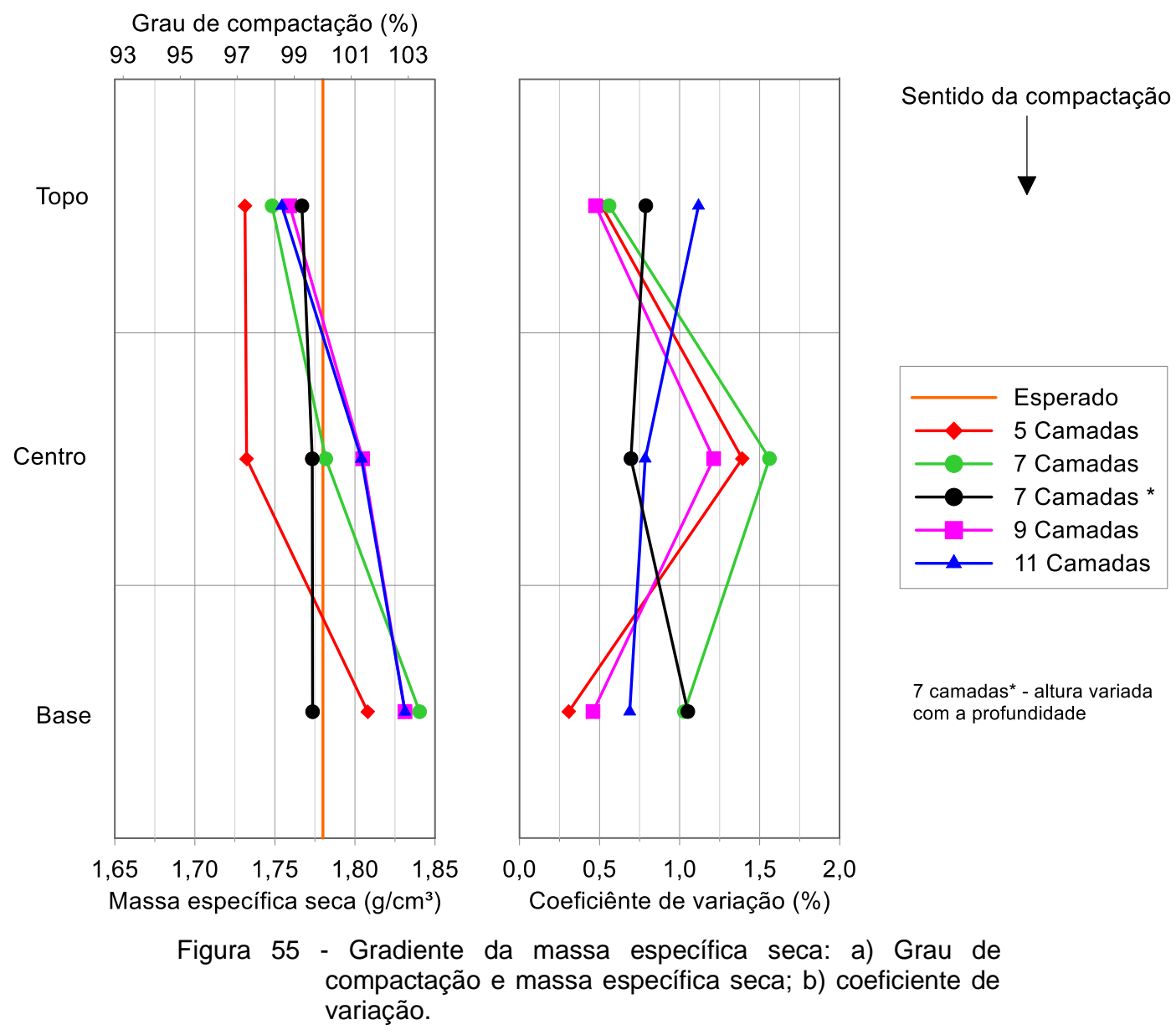

A fim de corrigir o efeito do gradiente de massa específica seca, desenvolveu-se uma metodologia que procura corrigir a transferência de tensões ao longo da amostra, compactando cada camada com espessuras diferentes entre si. A referida metodologia foi elucidada em maiores detalhes no Apêndice A. Pode-se conferir na Figura 55 o resultado da aplicação da metodologia citada, a partir do método denominado de 7 camadas*.

A condição 7 camadas* apresentou amostras mais uniformes em função do seu baixo gradiente de massa específica seca. $O$ coeficiente de variação retrata a variabilidade da massa específica seca do solo, obtida por meio da relação entre o desvio padrão e a média. A maior uniformidade da amostra pode ser observada por meio dos baixos valores de coeficientes de variação, variando entre 0,70\% a 1,05\%. Estes baixos valores indicam

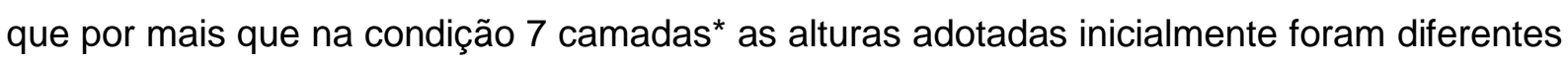


entre si, as finais (pós-compactação) apresentaram alturas aproximadamente iguais, reduzindo, por sua vez, o efeito do gradiente de massa específica seca da amostra.

Além da determinação da massa específica seca por intermédio do método da balança hidrostática foi realizada a estimativa da massa específica seca com auxílio de medidas diretas das espessuras finais de cada camada compactada, delimitadas nas interfaces tingidas com azul de metileno.

A Figura 56 mostra um comparativo das massas específicas secas determinadas por meio do método da balança hidrostática e pelo método das lentes tingidas com azul de metileno. A partir disso observou-se certa concordância nos valores obtidos de massa específica seca para os dois métodos avaliados.
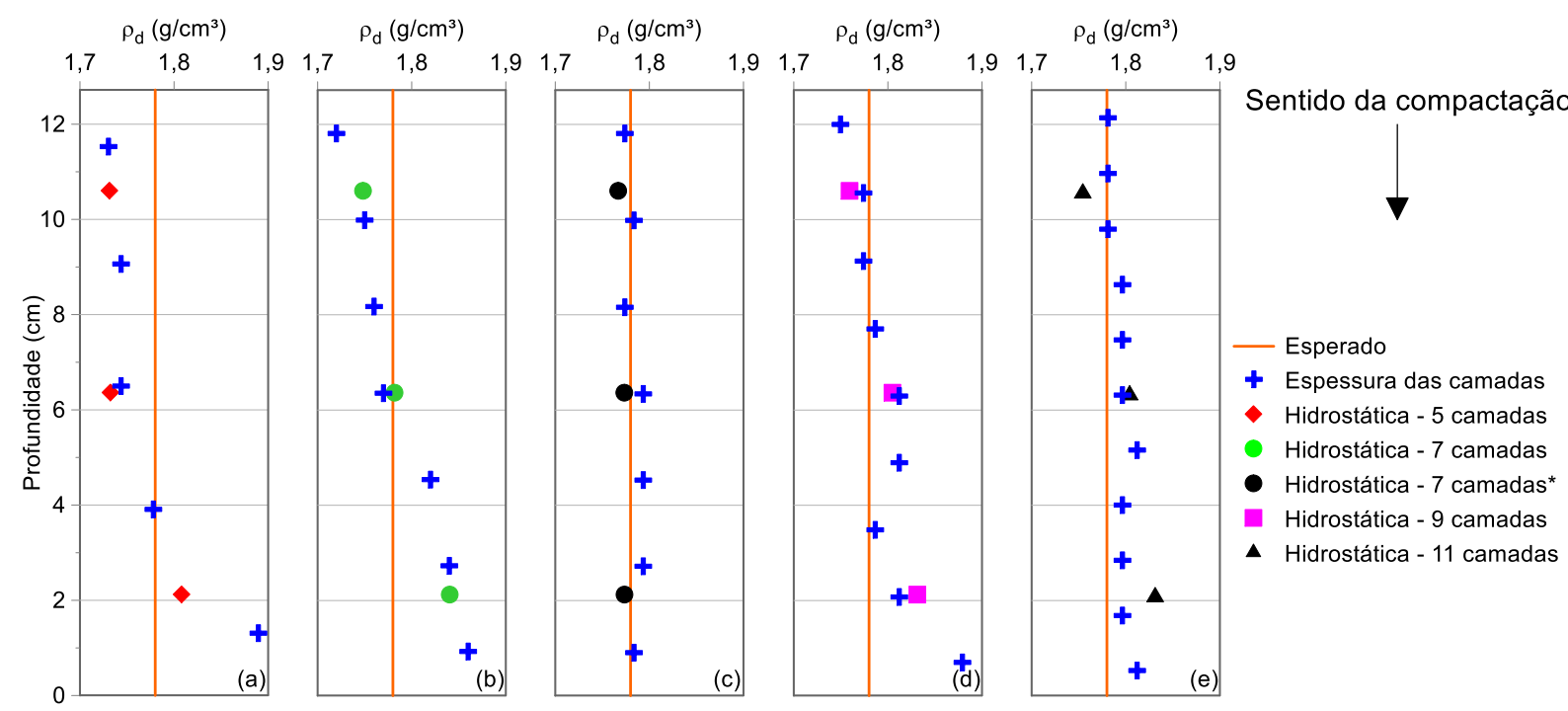

Figura 56 - Massas específicas secas para cada uma das condições
de compactação:
(a) 5 camadas; (b) 7 camadas;
(c) 7 camadas*
(modificado);
(d) 9 camadas e
(e) 11 camadas.

Sendo assim, a verificação das espessuras finais das camadas compactadas pode ser tratada como um indicativo expedito na avaliação da uniformidade dos corpos de prova. Em função da metodologia apresentada no Apêndice $A$ e dos resultados apresentados, adotou-se o método de compactação modificado (7 camadas*) para compactação das amostras utilizadas ao longo desta pesquisa.

\subsection{Preparação dos corpos de prova}

Para realização dos ensaios de condutividade hidráulica, compressão triaxial, bender elements e compressão confinada foram compactadas amostras utilizando o 
procedimento descrito em maiores detalhes na seção 4.5.1. A partir dessas amostras foram talhados corpos de prova nas direções paralela e ortogonal às camadas de compactação. $O$ processo de talhagem dos corpos de prova empregados nos ensaios de condutividade hidráulica, compressão triaxial e bender elements se deu conforme descrito na seção 4.5.2. Já a preparação dos corpos de prova para o ensaio de compressão confinada se deu por meio da cravação de anéis metálicos, conforme descrito na seção 4.5.3.

$\mathrm{Na}$ Tabela 9 são apresentados os índices físicos e as condições de ensaio dos corpos de prova utilizados na determinação da condutividade hidráulica e resistência ao cisalhamento. Constata-se que os valores de coeficiente de variação foram condizentes com os obtidos pelo método da balança hidrostática. A Tabela 10 apresenta os índices físicos de cada corpo de prova utilizado no ensaio de bender elements. As características dos corpos de prova para a realização dos ensaios de compressão confinada estão indicados na Tabela 11.

Tabela 9 - Características dos corpos de prova utilizados nos ensaios de condutividade hidráulica e compressão triaxial

\begin{tabular}{|c|c|c|c|c|c|c|c|c|c|c|c|c|c|}
\hline & Amostra & $\begin{array}{c}\sigma_{3}^{\prime} \\
(\mathrm{kPa})\end{array}$ & $\begin{array}{c}D \\
(\mathrm{~cm}) \\
\end{array}$ & $\begin{array}{c}\begin{array}{c}H \\
(\mathrm{~cm})\end{array} \\
\end{array}$ & $\begin{array}{c}V \\
\left(\mathrm{~cm}^{3}\right)\end{array}$ & $\begin{array}{l}M \\
(\mathrm{~g}) \\
\end{array}$ & $\begin{array}{c}w \\
(\%)\end{array}$ & $\begin{array}{c}\rho \\
\left(\mathrm{g} / \mathrm{cm}^{3}\right) \\
\end{array}$ & $\begin{array}{c}\rho_{d} \\
\left(\mathrm{~g} / \mathrm{cm}^{3}\right) \\
\end{array}$ & $\begin{array}{l}e \\
- \\
\end{array}$ & $\begin{array}{c}\mathrm{S}_{\mathrm{r}} \\
(\%)\end{array}$ & $\begin{array}{l}\text { GC } \\
(\%) \\
\end{array}$ & $\begin{array}{l}\text { CV } \\
(\%)\end{array}$ \\
\hline \multirow{8}{*}{ 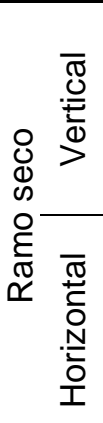 } & 29 & 50 & 4,98 & 10,28 & 200,04 & 381,3 & 13,1 & 1,906 & 1,685 & 0,594 & 59,4 & 94,6 & \multirow{4}{*}{0,7} \\
\hline & 29 & 100 & 4,99 & 10,29 & 200,99 & 380,5 & 13,2 & 1,893 & 1,673 & 0,606 & 58,5 & 94,0 & \\
\hline & 29 & 200 & 4,98 & 10,29 & 200,47 & 376,5 & 13,3 & 1,878 & 1,657 & 0,621 & 57,6 & 93,1 & \\
\hline & 30 & $400^{(1)}$ & 5,01 & 10,36 & 204,00 & 390,4 & 12,9 & 1,914 & 1,695 & 0,584 & 59,2 & 95,2 & \\
\hline & 28 & 50 & 5,01 & 10,20 & 201,16 & 376,0 & 12,7 & 1,869 & 1,659 & 0,619 & 55,0 & 93,2 & \multirow{4}{*}{0,1} \\
\hline & 28 & 100 & 4,98 & 10,11 & 196,84 & 368,5 & 12,7 & 1,872 & 1,662 & 0,617 & 55,2 & 93,3 & \\
\hline & 28 & 200 & 4,98 & 10,12 & 197,04 & 369,1 & 12,6 & 1,873 & 1,663 & 0,615 & 55,1 & 93,4 & \\
\hline & 28 & $400^{(1)}$ & 4,99 & 10,28 & 201,44 & 379,7 & 12,5 & 1,885 & 1,676 & 0,603 & 55,6 & 94,1 & \\
\hline \multirow{4}{*}{ 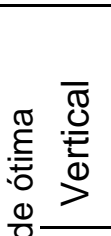 } & 10 & 50 & 5,00 & 10,18 & 199,60 & 403,1 & 15,7 & 2,019 & 1,745 & 0,539 & 78,2 & 98,1 & \multirow{4}{*}{0,2} \\
\hline & 10 & 100 & 5,05 & 10,19 & 204,30 & 414,5 & 15,5 & 2,029 & 1,757 & 0,529 & 78,7 & 98,7 & \\
\hline & 10 & 200 & 4,99 & 10,15 & 198,70 & 401,8 & 15,7 & 2,022 & 1,748 & 0,537 & 78,6 & 98,2 & \\
\hline & 24 & $400^{(1)}$ & 5,01 & 10,15 & 199,77 & 401,3 & 15,2 & 2,009 & 1,744 & 0,540 & 75,5 & 98,0 & \\
\hline \multirow{4}{*}{ 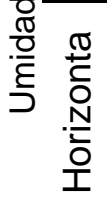 } & 11 & 50 & 4,92 & 10,25 & 194,76 & 395,5 & 15,5 & 2,031 & 1,758 & 0,528 & 79,0 & 98,8 & \multirow{4}{*}{0,3} \\
\hline & 11 & 100 & 4,94 & 10,09 & 193,02 & 391,3 & 15,6 & 2,027 & 1,754 & 0,532 & 78,8 & 98,5 & \\
\hline & 11 & 200 & 4,92 & 10,22 & 194,40 & 391,1 & 15,3 & 2,012 & 1,745 & 0,539 & 76,2 & 98,0 & \\
\hline & 11 & $400^{(1)}$ & 5,01 & 10,22 & 201,67 & 408,3 & 14,9 & 2,025 & 1,762 & 0,525 & 76,5 & 99,0 & \\
\hline \multirow{4}{*}{ 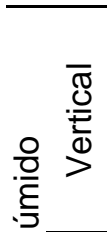 } & 26 & 50 & 4,95 & 10,17 & 195,79 & 388,5 & 16,9 & 1,984 & 1,697 & 0,583 & 78,1 & 95,3 & \multirow{4}{*}{0,4} \\
\hline & 26 & 100 & 5,01 & 10,17 & 200,77 & 401,8 & 16,9 & 2,001 & 1,712 & 0,569 & 79,8 & 96,2 & \\
\hline & 26 & 200 & 5,01 & 10,16 & 199,90 & 400,9 & 16,8 & 2,006 & 1,717 & 0,564 & 80,1 & 96,5 & \\
\hline & 26 & $400^{(1)}$ & 4,98 & 10,25 & 199,81 & 399,1 & 16,3 & 1,998 & 1,717 & 0,564 & 77,8 & 96,5 & \\
\hline \multirow{4}{*}{ 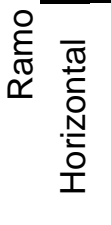 } & 27 & 50 & 5,01 & 10,09 & 198,55 & 399,3 & 17,0 & 2,011 & 1,719 & 0,563 & 81,1 & 96,6 & \multirow{4}{*}{0,5} \\
\hline & 27 & 100 & 5,01 & 10,17 & 200,70 & 404,0 & 16,8 & 2,013 & 1,723 & 0,559 & 80,9 & 96,8 & \\
\hline & 27 & 200 & 4,96 & 10,12 & 195,46 & 388,5 & 16,8 & 1,988 & 1,701 & 0,579 & 78,2 & 95,6 & \\
\hline & 27 & $400^{(1)}$ & 4,99 & 10,33 & 202,14 & 401,7 & 16,4 & 1,987 & 1,707 & 0,574 & 76,9 & 95,9 & \\
\hline
\end{tabular}

(1) Nesta tensão de confinamento não foi realizado ensaio de condutividade hidráulica. 
Tabela 10 - Características dos corpos de prova utilizados nos ensaios com bender elements

\begin{tabular}{|c|c|c|c|c|c|c|c|c|c|c|c|c|c|}
\hline & Amostra & $\begin{array}{c}\mathrm{CP} \\
- \\
\end{array}$ & $\begin{array}{c}D \\
(\mathrm{~cm}) \\
\end{array}$ & $\begin{array}{c}H \\
(\mathrm{~cm}) \\
\end{array}$ & $\begin{array}{c}V \\
\left(\mathrm{~cm}^{3}\right) \\
\end{array}$ & $\begin{array}{l}M \\
(\mathrm{~g}) \\
\end{array}$ & $\begin{array}{c}w \\
(\%)\end{array}$ & $\begin{array}{c}\rho \\
\left(\mathrm{g} / \mathrm{cm}^{3}\right) \\
\end{array}$ & $\begin{array}{c}\rho_{d} \\
\left(\mathrm{~g} / \mathrm{cm}^{3}\right) \\
\end{array}$ & $\begin{array}{l}e \\
-\end{array}$ & $\begin{array}{c}S_{r} \\
(\%)\end{array}$ & $\begin{array}{l}\mathrm{GC} \\
(\%)\end{array}$ & $\begin{array}{l}\mathrm{CV} \\
(\%)\end{array}$ \\
\hline \multirow{2}{*}{ V } & 24 & 1 & 4,98 & 10,17 & 198,33 & 372,1 & 12,7 & 1,876 & 1,664 & 0,614 & 55,8 & 93,5 & \multirow{4}{*}{0,5} \\
\hline & 29 & 2 & 4,99 & 10,30 & 201,72 & 380,5 & 12,8 & 1,887 & 1,673 & 0,606 & 56,6 & 93,9 & \\
\hline & 23 & 3 & 4,99 & 10,14 & 198,02 & 375,6 & 12,7 & 1,897 & 1,683 & 0,596 & 57,3 & 94,5 & \\
\hline & 23 & 4 & 5,00 & 9,83 & 193,09 & 367,2 & 12,5 & 1,902 & 1,691 & 0,589 & 57,0 & 94,9 & \\
\hline \multirow{2}{*}{ V } & 24 & 5 & 5,02 & 10,12 & 200,70 & 406,3 & 15,1 & 2,024 & 1,758 & 0,528 & 77,0 & 98,7 & \multirow{4}{*}{0,6} \\
\hline & 24 & 6 & 5,01 & 10,15 & 199,77 & 401,3 & 15,2 & 2,009 & 1,744 & 0,540 & 75,5 & 97,9 & \\
\hline \multirow{2}{*}{$\mathrm{H}$} & 24 & 7 & 5,17 & 10,25 & 215,09 & 428,9 & 15,3 & 1,994 & 1,730 & 0,552 & 74,3 & 97,2 & \\
\hline & 24 & 8 & 4,99 & 10,12 & 197,99 & 395,1 & 15,1 & 1,996 & 1,734 & 0,549 & 73,9 & 97,4 & \\
\hline \multirow{4}{*}{$\bar{\sim}$} & 25 & 9 & 5,04 & 10,24 & 204,33 & 406,5 & 16,8 & 1,990 & 1,703 & 0,577 & 78,3 & 95,6 & \multirow{4}{*}{0,8} \\
\hline & 25 & 10 & 5,02 & 10,21 & 201,88 & 401,4 & 16,9 & 1,989 & 1,702 & 0,578 & 78,3 & 95,6 & \\
\hline & 25 & 11 & 5,19 & 10,11 & 214,05 & 424,9 & 16,7 & 1,949 & 1,669 & 0,609 & 73,8 & 95,5 & \\
\hline & 25 & 12 & 4,98 & 10,25 & 199,89 & 398,1 & 16,5 & 1,992 & 1,710 & 0,571 & 77,5 & 96,0 & \\
\hline
\end{tabular}

Onde: RS-Ramo seco; UO-Umidade ótima; RU-Ramo úmido.

Tabela 11 - Características dos corpos de prova utilizados nos ensaios de compressão confinada

\begin{tabular}{cccccccccccccc}
\hline & & Amostra & $\begin{array}{c}\mathrm{CP} \\
-\end{array}$ & $\begin{array}{c}D \\
(\mathrm{~cm})\end{array}$ & $\begin{array}{c}H \\
(\mathrm{~cm})\end{array}$ & $\begin{array}{c}V \\
\left(\mathrm{~cm}^{3}\right)\end{array}$ & $\begin{array}{c}M \\
(\mathrm{~g})\end{array}$ & $\begin{array}{c}w \\
(\%)\end{array}$ & $\begin{array}{c}\rho \\
\left(\mathrm{g} / \mathrm{cm}^{3}\right)\end{array}$ & $\begin{array}{c}\rho_{d} \\
\left(\mathrm{~g} / \mathrm{cm}^{3}\right)\end{array}$ & $\begin{array}{c}e \\
-\end{array}$ & $\begin{array}{c}S_{r} \\
(\%)\end{array}$ & $\begin{array}{c}\mathrm{GC} \\
(\%)\end{array}$ \\
\hline \multirow{2}{*}{$\mathrm{RS}$} & $\mathrm{V}$ & 30 & 1 & 7,61 & 2,47 & 112,3 & 213,2 & 12,8 & 1,898 & 1,682 & 0,596 & 57,7 & 94,5 \\
& $\mathrm{H}$ & 30 & 2 & 7,61 & 2,47 & 112,3 & 215,2 & 13,0 & 1,916 & 1,695 & 0,585 & 59,9 & 95,2 \\
\hline \multirow{2}{*}{$\mathrm{UO}$} & $\mathrm{V}$ & 31 & 3 & 7,60 & 2,50 & 111,1 & 224,9 & 15,4 & 2,023 & 1,753 & 0,532 & 77,8 & 98,5 \\
& $\mathrm{H}$ & 31 & 4 & 7,60 & 2,50 & 113,0 & 230,4 & 15,4 & 2,040 & 1,767 & 0,520 & 79,6 & 99,3 \\
\hline \multirow{2}{*}{$\mathrm{RU}$} & $\mathrm{V}$ & 32 & 5 & 7,61 & 2,50 & 112,3 & 225,7 & 17,1 & 2,009 & 1,716 & 0,565 & 81,2 & 96,4 \\
& $\mathrm{H}$ & 32 & 6 & 7,61 & 2,50 & 112,3 & 225,8 & 17,0 & 2,010 & 1,718 & 0,564 & 81,0 & 96,5 \\
\hline
\end{tabular}

Onde: RS-Ramo seco; UO-Umidade ótima; RU-Ramo úmido.

No intuito de avaliar a acurácia e precisão dos teores de umidade e massas específicas secas foram inseridos sobre a curva de compactação (Figura 57) os 42 corpos de prova talhados (Tabelas: 9, 10 e 11) e também aqueles especificados como alvo (Tabela 4, seção 4.5). A partir desta análise foi possível observar que os corpos de prova talhados estão localizados ligeiramente abaixo da curva de compactação. Esta tendência pode estar atrelada às imperfeições na geometria dos corpos de prova, o que seria responsável pela leve redução do grau de compactação.

\subsection{Compressão confinada}

A tensão de "pré-adensamento" do solo compactado está intimamente relacionada à capacidade do solo em reter parte da energia aplicada durante a compactação. Mello (1977) propôs um modelo em que a resistência ao cisalhamento do solo compactado tem relação direta com a razão de sobreadensamento imposta durante o ensaio de compressão 
triaxial. Portanto, é de suma importância realizar ensaios de compressão confinada no intuito de auxiliar a interpretação dos ensaios triaxiais. Por mais que o solo compactado possa assumir um comportamento anisotrópico frente aos parâmetros de resistência, poucos trabalhos procuraram estudar o efeito da orientação das amostras na compressibilidade confinada de solos arenosos compactados.

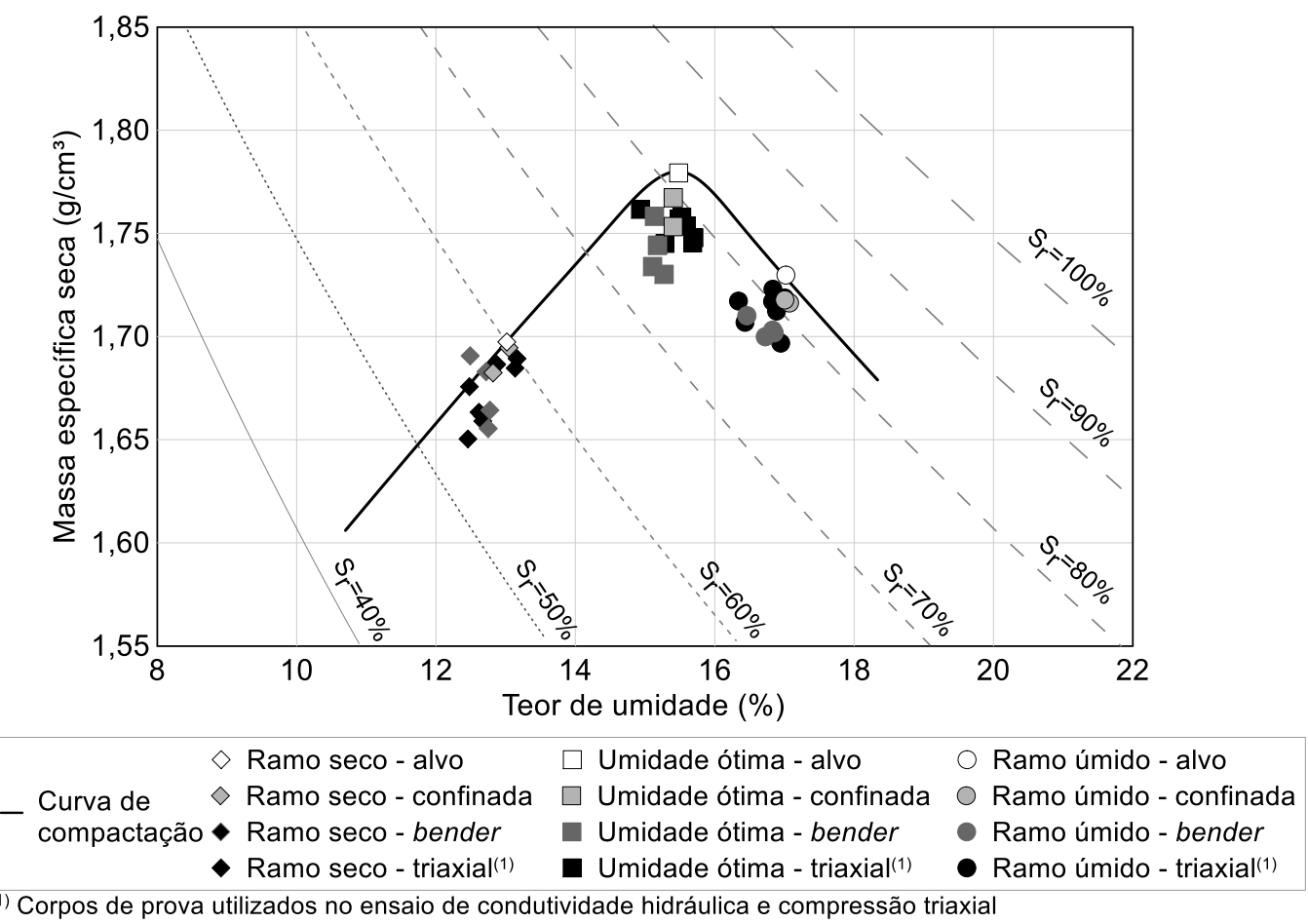

Figura 57 - Corpos de prova utilizados nos ensaios de compressão confinada, bender elements, condutividade hidráulica e compressão triaxial.

Os principais objetivos do ensaio de compressão confinada foram estimar a tensão de "pré-adensamento" e avaliar a compressibilidade para os corpos de prova talhados nas direções $\theta=90^{\circ}$ e $\theta=0^{\circ}$, a partir de amostras compactadas no ramo seco, umidade ótima e no ramo úmido da curva de compactação. As amostras foram compactadas e posteriormente talhadas nas duas direções, conforme descrito na seção 4.5.3. Após a talhagem, os corpos de prova foram colocados em prensas de adensamento, mantidos em condição inundada e, submetidos a uma tensão normal de aproximadamente 12,5 kPa por um período de 24 horas antes da aplicação das cargas adicionais.

A Figura 58 apresentam as curvas de compressão confinada correspondentes às duas direções de talhagem, representadas por meio do índice de vazios normalizados $\left(\mathrm{e} / \mathrm{e}_{0}\right)$, em função das sobrecargas, para os corpos de prova compactados no ramo seco, umidade ótima e ramo úmido. Nota-se alguma influência da orientação das amostras a depender do teor de umidade de compactação e do nível de carregamento aplicado. 

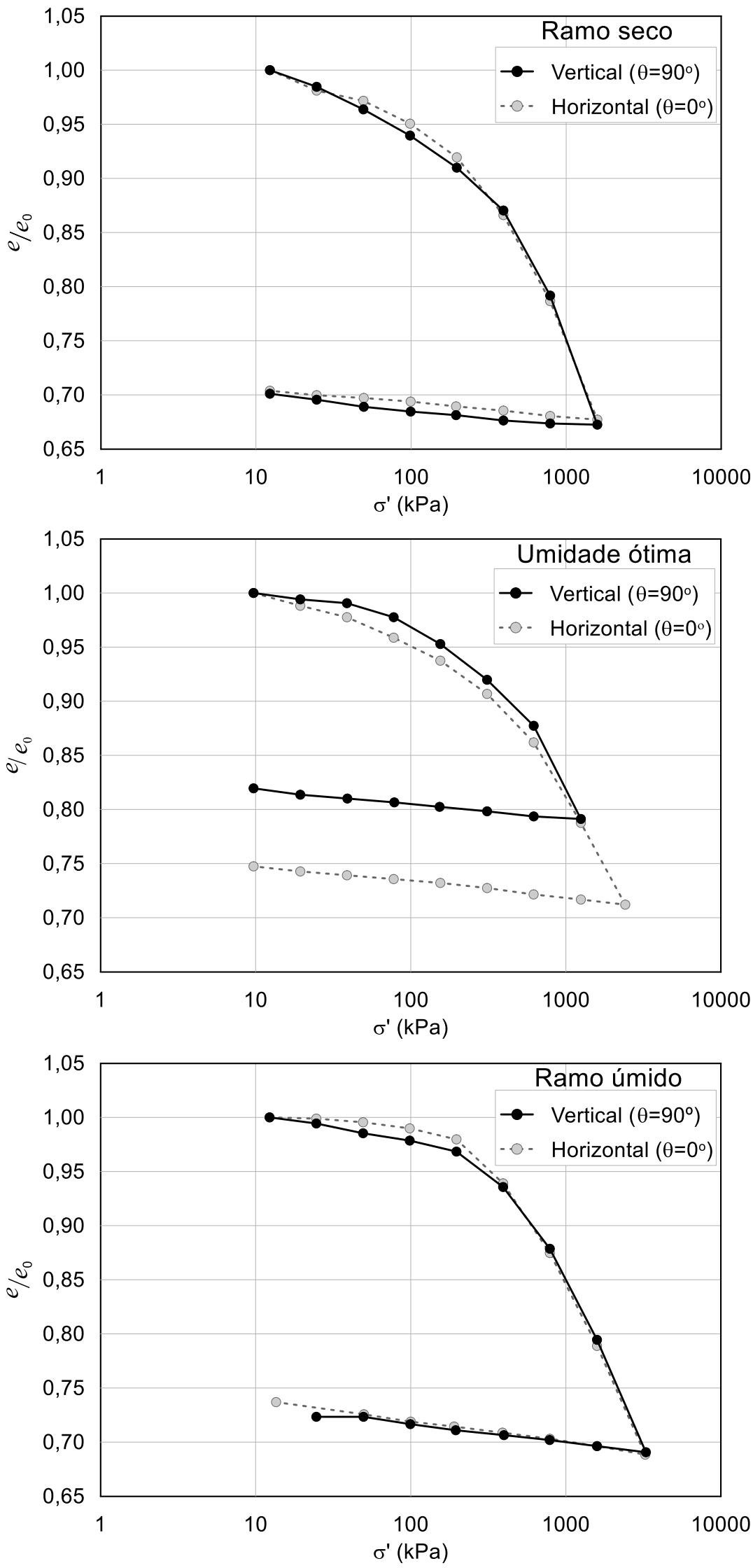

Figura 58 - Curvas de compressão confinada para os corpos de prova talhados na direção vertical e horizontal. 
A Tabela 12 apresenta os resultados dos ensaios de compressão confinada. As tensões de "pré-adensamento" foram estimadas conforme os métodos gráficos propostos por Casagrande (1936) e Pacheco Silva (1970). A partir da tensão de "pré-adensamento" obtida pelo método de Pacheco Silva (1970) $\left(\sigma^{\prime}{ }^{\prime a d}\right)$ determinaram-se os índices de compressão $\left(C_{\mathrm{c}}\right)$, expansão $\left(C_{\mathrm{s}}\right)$ e recompressão $\left(C_{\mathrm{r}}\right)$.

Tabela 12 - Resultados dos ensaios de compressão confinada

\begin{tabular}{|c|c|c|c|c|c|c|c|c|c|c|c|c|}
\hline & & Amostra & $C P$ & $W_{\text {inicial }}$ & $w_{\text {final }}$ & $e_{0}$ & $e_{\text {final }}$ & $\sigma_{\mathrm{ad}}^{(\mathrm{p})}$ & $\sigma^{\prime}{ }^{(c)}$ & $C_{\mathrm{c}}$ & $C_{\mathrm{s}}$ & $C_{\mathrm{r}}$ \\
\hline & & & - & $(\%)$ & $(\%)$ & - & - & $(\mathrm{kPa})$ & $(\mathrm{kPa})$ & & - & \\
\hline \multirow{2}{*}{$\underset{\mathscr{C}}{\mathscr{C}}$} & V & 30 & 1 & 12,8 & 16,8 & 0,596 & 0,412 & 439 & 524 & 0,21 & 0,01 & 0,03 \\
\hline & $\mathrm{H}$ & 30 & 2 & 13,0 & 16,6 & 0,585 & 0,406 & 359 & 394 & 0,24 & 0,01 & 0,04 \\
\hline \multirow{2}{*}{$\stackrel{\bigcirc}{\supset}$} & V & 31 & 3 & 15,4 & 17,7 & 0,532 & 0,434 & 379 & 359 & 0,13 & 0,01 & 0,02 \\
\hline & $\mathrm{H}$ & 31 & 4 & 15,4 & 15,3 & 0,520 & 0,387 & 320 & 353 & 0,15 & 0,01 & 0,02 \\
\hline \multirow{2}{*}{$\stackrel{\partial}{\sim}$} & V & 32 & 5 & 17,0 & 15,7 & 0,565 & 0.406 & 473 & 420 & 0,17 & 0,01 & 0,02 \\
\hline & $\mathrm{H}$ & 32 & 6 & 17,1 & 16,6 & 0,564 & 0,413 & 424 & 385 & 0,17 & 0,01 & 0,02 \\
\hline
\end{tabular}

Os índices de expansão $\left(C_{s}\right)$ e os de recompressão $\left(C_{r}\right)$ mostraram-se praticamente independentes da umidade na compactação, no entanto, os índices de compressão $\left(C_{c}\right)$ sofreram influência da condição de umidade de compactação. Os corpos de prova correspondentes ao ramo seco apresentaram maiores valores de índice de compressão $\left(C_{c}\right)$, indicando ser mais compressível que os demais. Entretanto, a compressibilidade pode ser avaliada a cada incremento de tensão por meio da determinação do módulo de compressão confinada $(D)$.

O ensaio de compressão confinada permite, entre outros resultados, a determinação do módulo de compressão confinada $(D)$, que por sua vez se assemelha ao módulo de elasticidade $(E)$, diferenciando-se daquele pelas condições de confinamento durante o ensaio (BARATA, 1984). Enquanto o módulo de elasticidade (E) é determinado por meio de ensaios de compressão simples, o módulo de compressão confinada $(D)$ resulta do ensaio edométrico, em que ocorre confinamento integral da amostra.

Pode-se apreciar na Figura 59 os módulos de compressão confinada $(D)$ em função das sobrecargas, para as amostras compactadas no ramo seco, na umidade ótima e no ramo úmido, talhadas nas duas direções de ensaio. Observa-se pelo aspecto da curva, que o módulo de compressão confinada $(D)$ cresce com o aumento das tensões aplicadas, o que é justificado pela consecutiva redução da massa específica do solo, o que o torna mais resistente e menos compressível. 
De uma maneira geral, para sobrecargas menores que $200 \mathrm{kPa}$, observa-se maior influência do teor de umidade de compactação e da orientação das amostras. Ainda para tensões menores que $200 \mathrm{kPa}$, o ramo úmido apresentou maiores valores de módulo, enquanto que o ramo seco apresentou-se mais compressível que os demais. A maior compressibilidade observada no ramo seco está associada à maior presença de macroporos (BORGES, 2014). Com relação à influência da orientação das amostras na compressibilidade, notam-se que as maiores diferenças foram obtidas para carregamentos inferiores a $200 \mathrm{kPa}$. Os módulos de compressão confinada $(D)$ na umidade ótima apresentaram-se até 2,5 vezes maiores na direção vertical do que na direção horizontal, entretanto, foram obtidos maiores módulos $(D)$ na direção horizontal do que na direção vertical para os corpos de prova compactados no ramo seco e ramo úmido da curva de compactação.

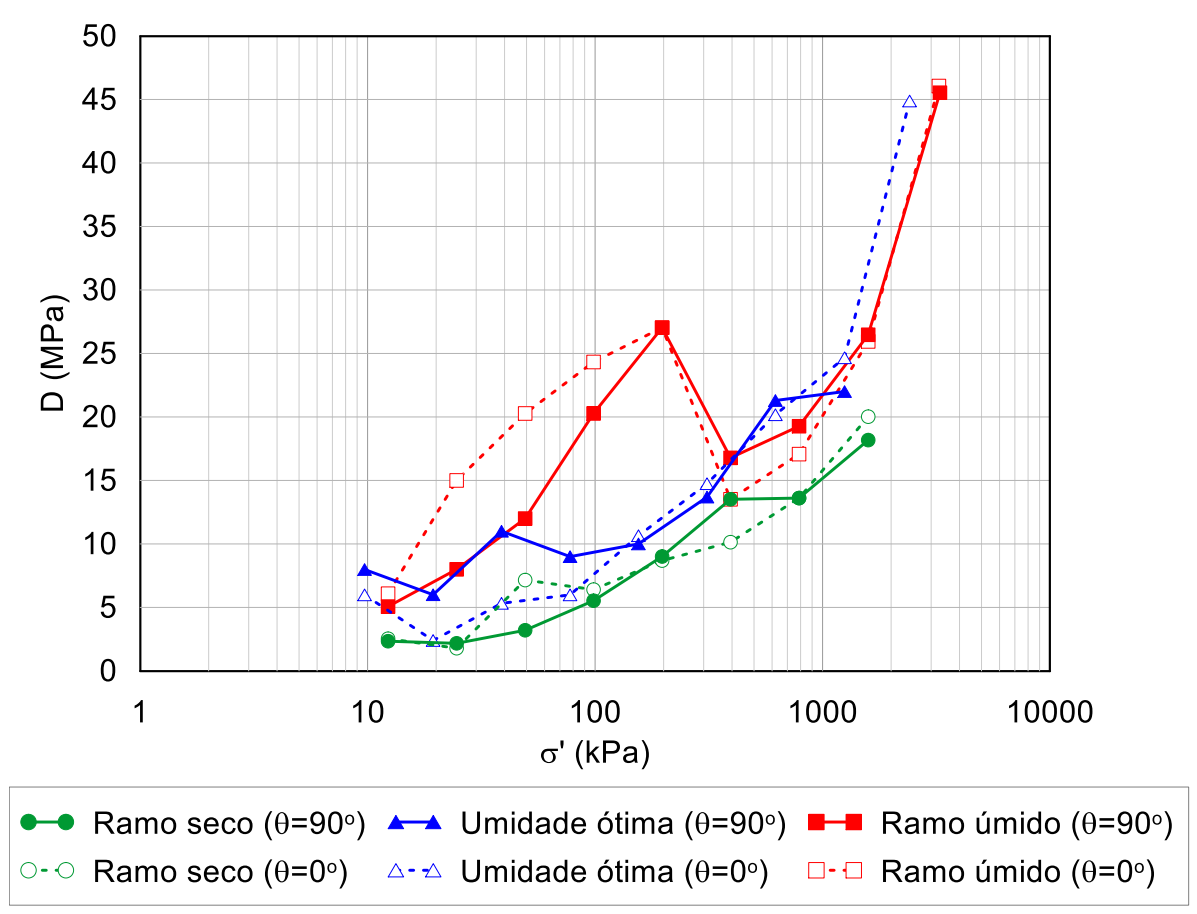

Figura 59 - Módulos de compressão confinada $(D)$ para as amostras preparadas no ramo seco, umidade ótima e ramo úmido da curva de compactação.

A análise do módulo de compressão confinada $(D)$ ilustra uma maior influência da orientação dos corpos de prova para níveis iniciais de carregamento, o que serviu como estímulo para estudar as propriedades elásticas do solo em baixos níveis de tensões. Uma das maneiras em se conhecer as propriedades elásticas do material resulta da obtenção do módulo de cisalhamento máximo do solo $\left(G_{\max }\right)$, que por sua vez, tem relação com o módulo 
de elasticidade $(E)$. O módulo de cisalhamento máximo do solo $\left(G_{\max }\right)$ foi obtido por meio da técnica de bender elemens, conforme descrito em maiores detalhes na seção 5.9.

A estrutura formada inicialmente durante processo de compactação pouco explica o desempenho elástico do material na medida em que o solo é sujeito a carregamentos consecutivos, conforme ilustra a Figura 59. Nota-se nesta figura que ao submeter as amostras a carregamentos maiores que $200 \mathrm{kPa}$, os módulos de compressão confinada apresentaram resultados praticamente independentes das condições de compactação e talhagem (teor de umidade e orientação das amostras), de modo que houve uma convergência nos valores dos módulos. A convergência observada nas sobrecargas maiores que a tensão de "pré-adensamento" tem aplicação direta em modelos elastoplásticos. Comportamentos similares são observados para solos compactados (BORGES, 2014; OTÁLVARO; CORDÃO NETO; CAICEDO, 2015) e também para solos naturais (LEROUEIL; VAUGHAN, 1990; FUTAI, 2002; KYOKAWA, 2010).

Recentemente, Borges (2014) avaliou, em um solo laterítico compactado, o efeito da sobrecarga na distribuição de poros das amostras. Os resultados deste estudo demostraram que a estrutura inicial tem maior efeito nos carregamentos iniciais e, após um determinado nível de sobrecarga as amostras apresentam desempenhos mecânicos similares. Assis, Hernandez e Colmanetti (2006) afirmaram que o efeito da compactação tem maior importância para faixas de sobrecargas inferiores a de "pré-adensamento". Este comportamento pode estar associado às alterações estruturais promovidas pelo carregamento, desenvolvidas por meio de uma progressiva redução dos macroporos presentes nas amostras. Portanto, para níveis de carregamentos muito elevados, a resposta mecânica do solo passa a não depender da estrutura inicial.

Desse modo, acredita-se que uma análise da influência da orientação dos corpos de prova na tensão de "pré-adensamento" se faz necessária na interpretação do papel da estrutura no desempenho mecânico do solo. Notou-se que os corpos de prova talhados na direção vertical mostraram tensões de "pré-adensamento" maiores do que na direção horizontal. Para as amostras compactadas no ramo seco, na umidade ótima e no ramo úmido, esta relação apresentou-se na ordem de $22 \%, 18 \%$ e $11 \%$, respectivamente. Por mais que existam incertezas quanto à estimativa da tensão de "pré-adensamento", considerou-se que estas diferenças observadas nas amostras compactadas com o mesmo teor de umidade, estejam relacionadas com a capacidade do solo em reter a energia de compactação nas direções vertical e horizontal.

As alterações estruturais promovidas pelos elevados carregamentos impostos a solos compactados podem contribuir para a redução da anisotropia inerente das propriedades hidráulicas e mecânicas junto ao processo de compactação. Este fato fornece 
subsídios para a avaliação da influência da orientação dos corpos de prova no comportamento hidráulico e mecânico do solo.

\subsection{Condutividade hidráulica}

Diversos fatores interferem na condutividade hidráulica do solo compactado dentre os quais é possível destacar: a anisotropia, o teor de umidade de compactação e, a tensão de confinamento aplicada no corpo de prova durante o ensaio. De ordem prática, a correta avaliação destas variáveis contribui para uma previsão mais precisa do desempenho hidráulico em obras como barragens de terra e, como revestimento de fundo de aterros sanitários. A avaliação do comportamento do solo frente a estas variáveis pode indicá-lo com apropriado na construção de barreiras para retenção de contaminantes em aterros sanitários, tendo assim, aplicação direta na geotecnia ambiental. Quando apropriadamente compactado, os solos finos lateríticos podem apresentar baixa condutividade hidráulica, tendo ação atenuante do lixiviado (OSINUBI; NWAIWU, 2002, 2005, 2006).

Nesta etapa da pesquisa, buscou-se avaliar a influência do teor de umidade de compactação, tensão de confinamento e orientação dos corpos de prova na condutividade hidráulica do solo na condição saturada. Após a fase de saturação dos corpos de prova $(\bar{B} \geq 0,98)$, os mesmos foram submetidos ao adensamento isotrópico. As tensões de confinamento utilizadas foram de 50, 100 e $200 \mathrm{kPa}$. Após a fase de consolidação, cada corpo de prova foi submetido a um fluxo ascendente, oferecido pela diferença de $10 \mathrm{kPa}$ nas pressões entre a base e o topo do corpo de prova.

A Tabela 13 resume os valores médios ao longo do tempo para a condutividade hidráulica nos corpos de prova submetidos a fluxo ortogonal ao plano de compactação $\left(k_{v}\right) \mathrm{e}$ paralelo ao plano de compactação $\left(k_{h}\right)$. Além disso, a referida tabela apresenta os valores da relação $k_{h} \mathrm{k}_{\mathrm{v}}$ (razão de anisotropia) para cada tensão de confinamento. Os valores apresentados na Tabela 13 também são indicados nas Figuras 60 e 61.

Tabela 13 - Parâmetros hidráulicos do solo para os corpos de prova talhados na direção vertical $\left(k_{v}\right)$ e horizontal $\left(k_{h}\right)$

\begin{tabular}{|c|c|c|c|c|c|c|c|c|c|}
\hline \multirow{2}{*}{$\begin{array}{c}\sigma_{3}^{\prime} \\
(\mathrm{kPa})\end{array}$} & \multicolumn{3}{|c|}{ Ramo seco } & \multicolumn{3}{|c|}{ Umidade ótima } & \multicolumn{3}{|c|}{ Ramo úmido } \\
\hline & $k_{h}(\mathrm{~m} / \mathrm{s})$ & $k_{v}(\mathrm{~m} / \mathrm{s})$ & $k_{h} / k_{v}$ & $k_{h}(\mathrm{~m} / \mathrm{s})$ & $k_{v}(\mathrm{~m} / \mathrm{s})$ & $k_{h} / k_{v}$ & $k_{h}(\mathrm{~m} / \mathrm{s})$ & $k_{v}(\mathrm{~m} / \mathrm{s})$ & $k_{h} / k_{1}$ \\
\hline 50 & $9,6 \times 10^{-7}$ & $3,0 \times 10^{-7}$ & 3,2 & $7,5 \times 10^{-8}$ & $3,8 \times 10^{-8}$ & 2,0 & $1,2 \times 10^{-7}$ & $1,5 \times 10^{-8}$ & 7,9 \\
\hline 100 & $3,5 \times 10^{-8}$ & $2,4 \times 10^{-8}$ & 1,4 & $3,3 \times 10^{-8}$ & $8,5 \times 10^{-9}$ & 3,9 & $5,2 \times 10^{-8}$ & $1,3 \times 10^{-8}$ & 3,8 \\
\hline 200 & $3,2 \times 10^{-8}$ & $2,3 \times 10^{-8}$ & 1,4 & $2,8 \times 10^{-8}$ & $6,0 \times 10^{-9}$ & 4,7 & $4,8 \times 10^{-8}$ & $1,3 \times 10^{-8}$ & 3,7 \\
\hline
\end{tabular}


A Figura 60 mostra a variação das condutividades hidráulicas verticais $\left(k_{v}\right)$ e horizontais $\left(k_{h}\right)$ em função da tensão de confinamento mantido durante o ensaio de condutividade hidráulica. Nota-se o efeito do teor de umidade de compactação e da tensão de confinamento na condutividade hidráulica do solo.

Independente da orientação dos corpos de prova, o aumento da tensão de confinamento propiciou a redução da condutividade hidráulica em todas as amostras ensaiadas. No entanto, este efeito foi mais pronunciado para tensões confinantes de 50 e $100 \mathrm{kPa}$. Para tensão confinante de $200 \mathrm{kPa}$, a diminuição do índice de vazios não foi suficiente para causar reduções significativas na condutividade hidráulica. Estes resultados vão ao encontro das análises realizadas por Shafiee (2008). O referido autor observou em misturas de solo-agregado, que o aumento da tensão de confinamento proporciona redução da condutividade hidráulica até um determinado estado de tensões, de modo que elevadas tensões de confinamento não desenvolveram mudanças significativas na condutividade hidráulica do material.

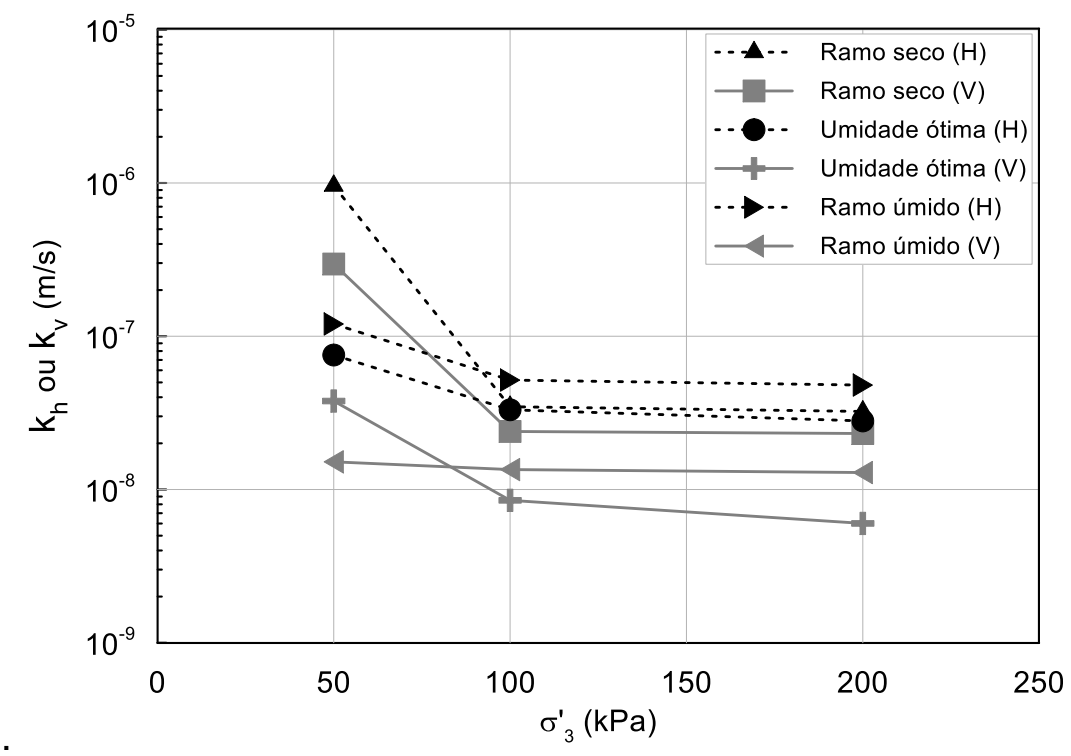

Figura 60 - Efeito da tensão de confinamento na condutividade hidraulica na direção vertical (V) e na direção horizontal (H).

A tensão de confinamento tem influência direta na anisotropia de condutividade hidráulica $\left(k_{h} / \mathrm{k}_{\mathrm{v}}\right)$, conforme pode ser visto na Figura 61 . Os valores da relação $k_{h} / \mathrm{k}_{\mathrm{v}}$ nas amostras estudadas variaram de 1,4 a 7,9. Nas amostras compactadas no ramo seco como no ramo úmido, as relações $k_{h} / \mathrm{k}_{\mathrm{v}}$ diminuíram com o aumento da tensão confinante. Em contrapartida, no caso das amostras compactadas na umidade ótima, as relações $k_{h} / \mathrm{k}_{\mathrm{v}}$ 
aumentaram com o aumento da tensão confinante. $\mathrm{O}$ aumento da relação $k_{h} \mathrm{~K}_{\mathrm{v}}$ registrada para o teor de umidade ótimo deve-se aos possíveis erros experimentais, falta de repetibilidade de ensaio e/ou falta de submeter o solo a maiores níveis de tensão de confinamento durante o ensaio de condutividade hidráulica.

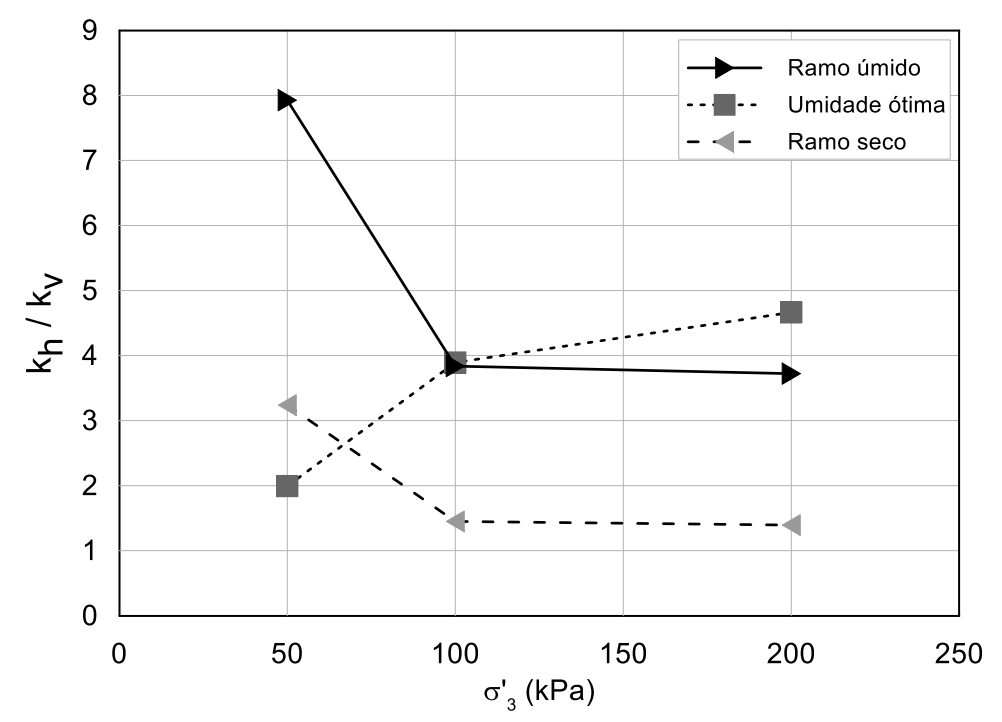

Figura 61 - Efeito da tensão de confinamento na relação de condutividade hidráulica na direção horizontal e vertical.

As maiores diferenças entre $k_{h}$ e $k_{v}$ foram observados no ramo úmido da curva de compactação. Esta situação pode estar relacionada à menor quantidade de macroporos e a uma possível orientação preferencial das partículas, dispostas paralelamente ao plano de compactação, induzindo por sua vez, maior fluxo na direção horizontal quando comparado ao fluxo na direção vertical.

Nos ensaios de compressão confinada pôde-se observar a convergência da compressibilidade das amostras quando submetidas a elevados níveis de carregamento. A redução da anisotropia de condutividade hidráulica, também experimenta certa convergência quando as amostras são submetidas a incrementos sucessivos de tensões de confinamento, refletidos pela redução das diferenças entre $k_{h}$ e $k_{v}$ (Figura 61). Considerando que $o$ incremento das tensões de confinamento cause progressiva redução dos macroporos contidos nas amostras, supõe-se que o efeito da anisotropia inerente, na estrutura do solo compactado, tenha maior contribuição quanto menor for a confinante a qual estará sujeita.

A fim de mostrar a influência do teor de umidade de compactação na condutividade hidráulica são apresentados na Figura 62 os resultados dos ensaios referentes às duas direções de talhagem, para as três tensões de confinamento estudadas. Em linhas gerais, os menores valores de condutividade hidráulica foram obtidos nos teores de umidade ótimo, independente da direção de talhagem. Geralmente, o menor valor de condutividade 
hidráulica é encontrado para teores de umidade levemente maiores que o teor de umidade ótima (MITCHELL; SOGA, 2005; OSINUBI; NWAIWU, 2005).

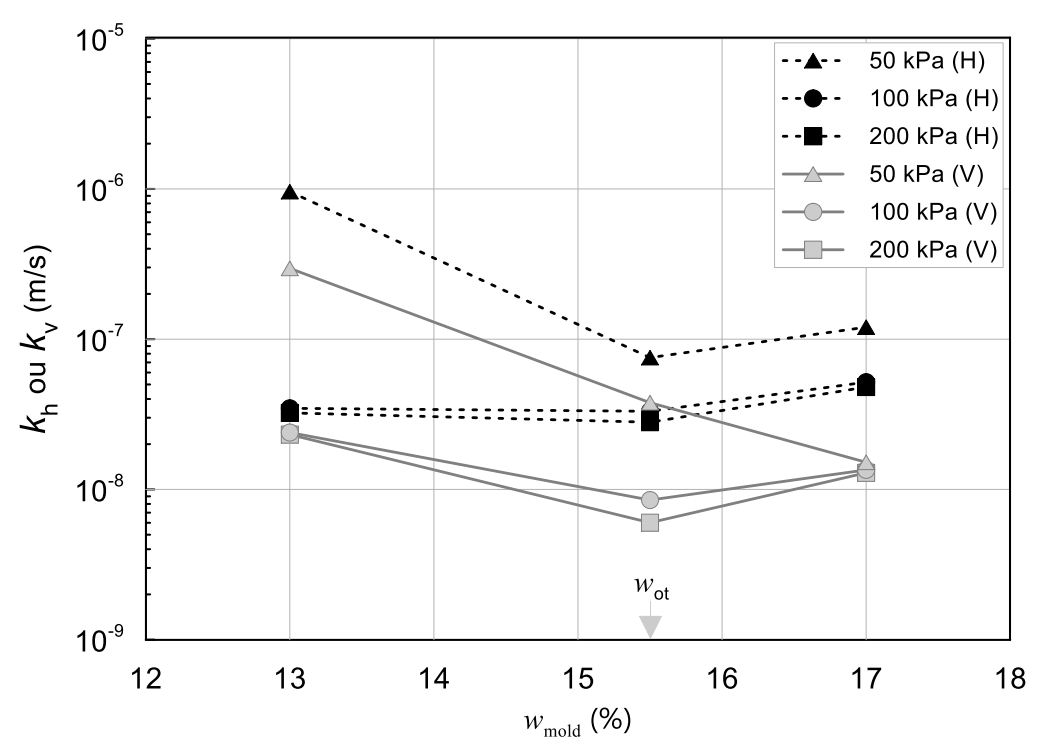

Figura 62 - Efeito da condição de moldagem, direção de fluxo e tensão de confinamento na condutividade hidráulica.

\subsection{Resistência ao cisalhamento}

Os ensaios de compressão triaxial, do tipo consolidado não drenado (CU), foram realizados após a fase de condutividade hidráulica em corpos de prova talhados segundo as duas direções (vertical e horizontal). Os ensaios foram realizados com as tensões de confinamento de 50, 100, 200 e $400 \mathrm{kPa}$. Os corpos de prova foram saturados para se evitar a influência da sucção nos resultados.

As Figuras 63, 64 e 65 apresentam os resultados gráficos das diferenças de tensões principais $\left(\sigma_{1}-\sigma_{3}\right)$, das relações entre tensões efetivas $\left(\sigma_{1}^{\prime} / \sigma_{3}^{\prime}\right)$ e pressões da água intersticial $(u)$, em função das deformações axiais $\left(\varepsilon_{\mathrm{a}}\right)$ obtidas durante os ensaios.

De maneira geral, ao observar as curvas tensão-deformação axial, seja em termos de $\sigma_{1}-\sigma_{3}$ ou termos de $\sigma_{1}{ }^{\prime} / \sigma_{3}{ }^{\prime}$, nota-se que os corpos de prova talhados na direção vertical, quando submetidos à mesma tensão de confinamento, apresentam picos de $\sigma_{1}-\sigma_{3}$ em deformações axiais menores que aqueles talhados na direção horizontal.

Nota-se na Figura 63a que os corpos de prova compactados no ramo seco e talhados na direção vertical apresentam picos de diferença de tensões principais em deformações menores que 3\%. A partir do desenvolvimento das deformações axiais observa-se a redução acentuada da resistência, desempenho típico de ruptura frágil. Verifica-se que as amostras compactadas na umidade ótima (Figura 64) e ramo úmido 
(Figura 65), talhadas na direção horizontal, apresentaram ligeiro aumento de resistência à medida que foram desenvolvidas as deformações axiais. Este ligeiro aumento da relação $\sigma_{1}-\sigma_{3}$, com incremento das deformações axiais, reflete ao aumento das tensões efetivas em virtude da redução na pressão da água intersticial durante o ensaio (OLIVEIRA, 2004). O aumento inicial na pressão da água intersticial, acompanhada de sua posterior redução ao longo das deformações axiais, pode vir a apresentar valores negativos e desenvolver erros sistêmicos na interpretação do ensaio (BISHOP; HENKEL, 1962).

Em função dos picos obtidos pelo critério $\sigma_{1}-\sigma_{3}$ foi observado que os corpos de prova compactados no ramo úmido e talhados na direção vertical apresentaram deformações axiais por volta de $4 \%$, enquanto que aqueles talhados na direção horizontal apresentaram maiores deformações axiais na ruptura, a saber, 8\%. Além disso, independente do teor de umidade de compactação, os corpos de prova talhados na direção horizontal desenvolveram maiores valores de pressão da água intersticial durante o ensaio, indicando assim, estruturas mais susceptíveis à variação de volume.

(a)

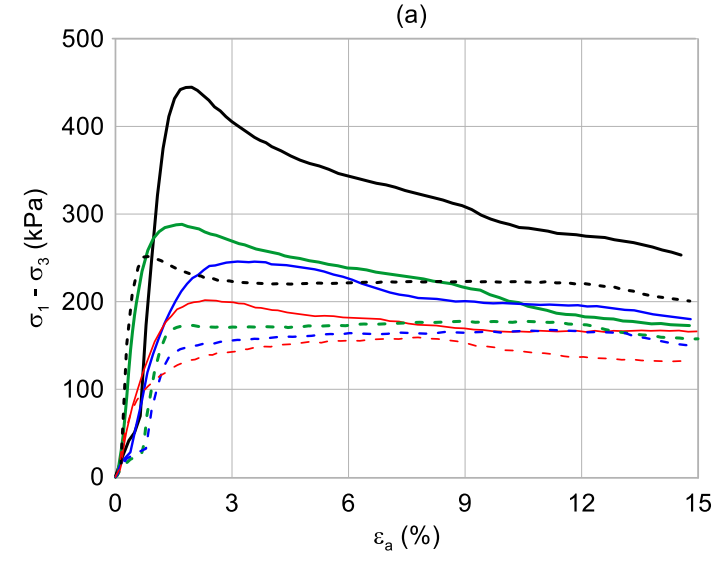

(b)

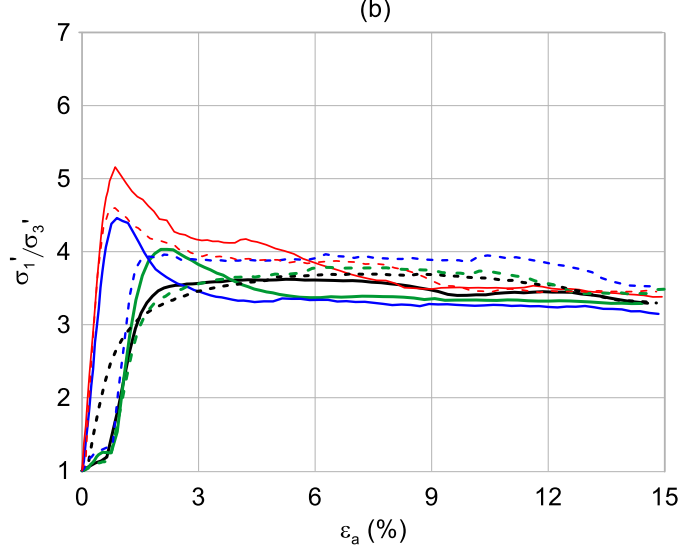

(c)

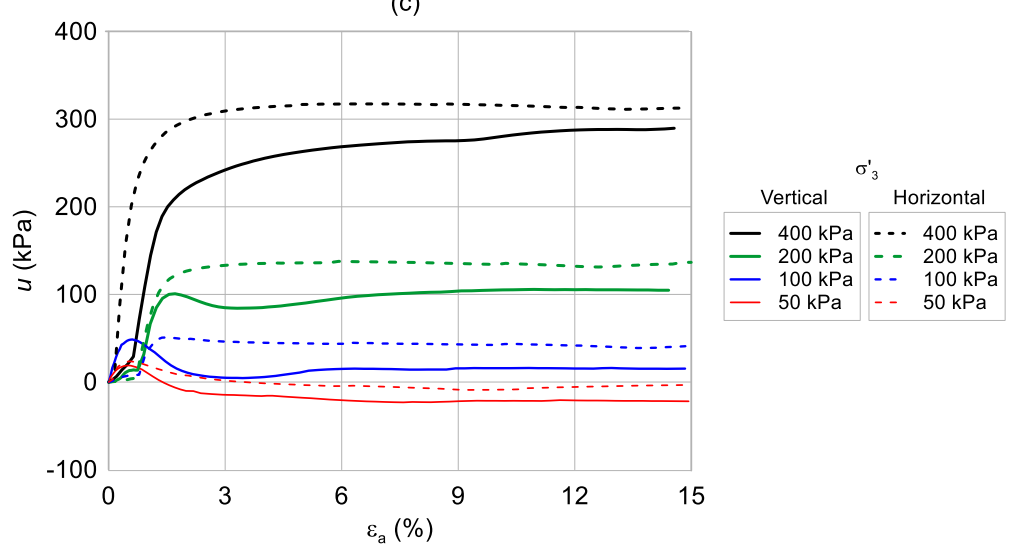

Figura 63 - Ensaios CU com amostras compactadas no ramo seco: (a)

(b) tensão-deformação; (c) pressão da água intersticial. 
(a)

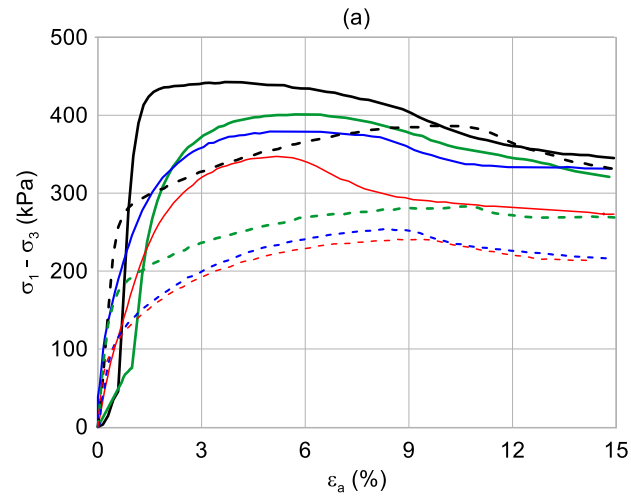

(b)

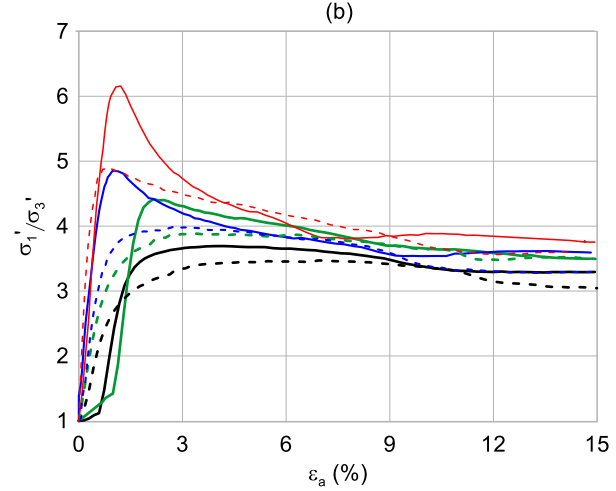

(c)

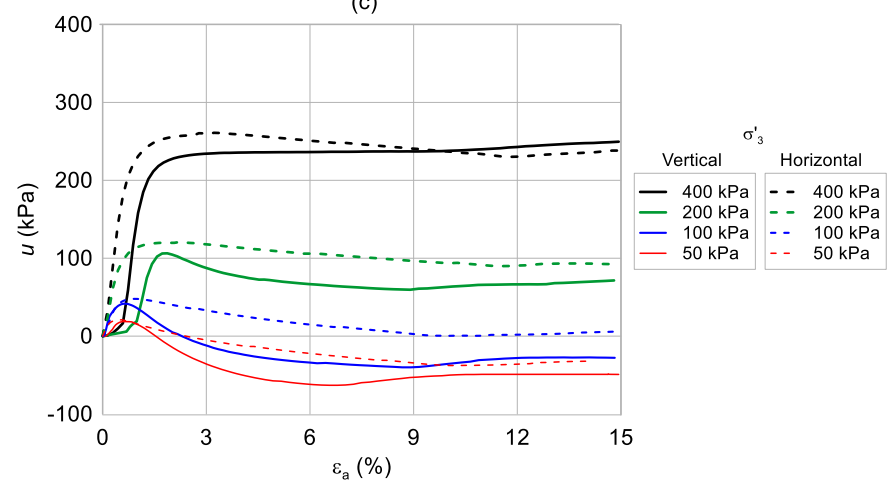

Figura 64 - Ensaios CU com amostras compactadas na umidade ótima: (a) (b) tensão-deformação; (c) pressão da água intersticial.
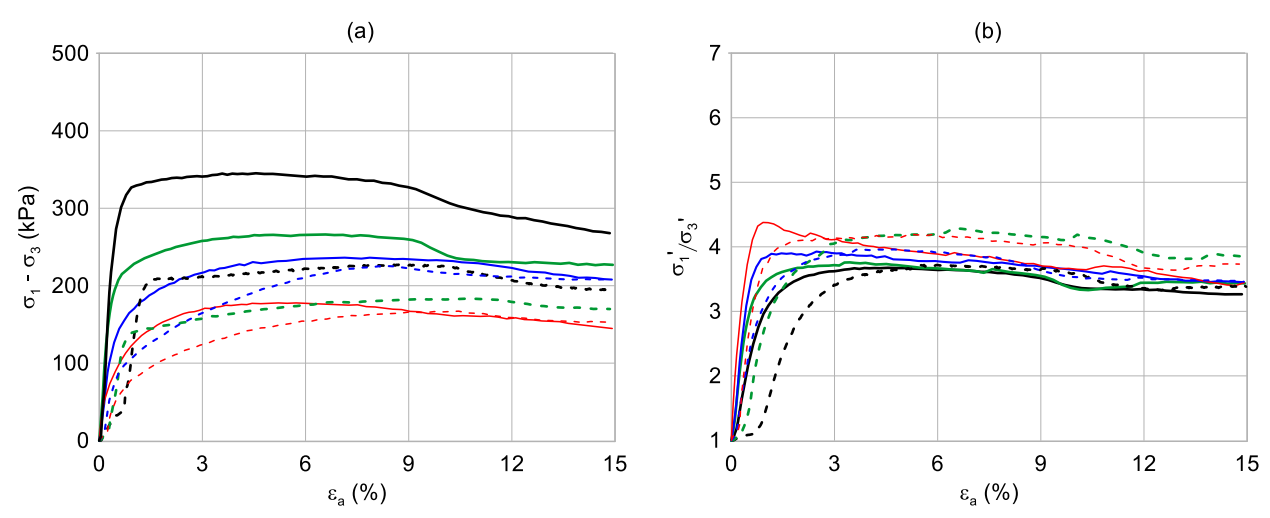

(c)

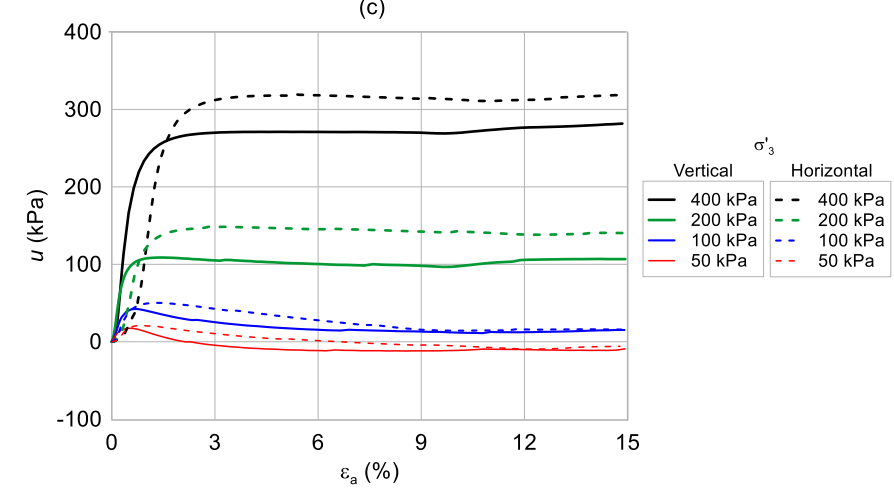

Figura 65 - Ensaios CU com amostras compactadas no ramo úmido: (a) (b) tensão-deformação; (c) pressão da água intersticial. 
A Figura 66 apresenta as trajetórias de tensões efetivas para as amostras compactadas no ramo seco, umidade ótima e ramo úmido. Por meio dessas trajetórias observou-se a existência de certa diferença relacionada à direção de talhagem dos corpos de prova, que tende a diminuir no regime pós-pico. O maior valor da pressão da água intersticial na direção horizontal faz com que a trajetória de tensões efetivas tenha maior deslocamento, quando comparados aos corpos de prova talhados na direção vertical. Acredita-se que as variações de pressão da água intersticial estejam relacionadas à diferença de tensão de "pré-adensamento" entre as duas direções ensaiadas.
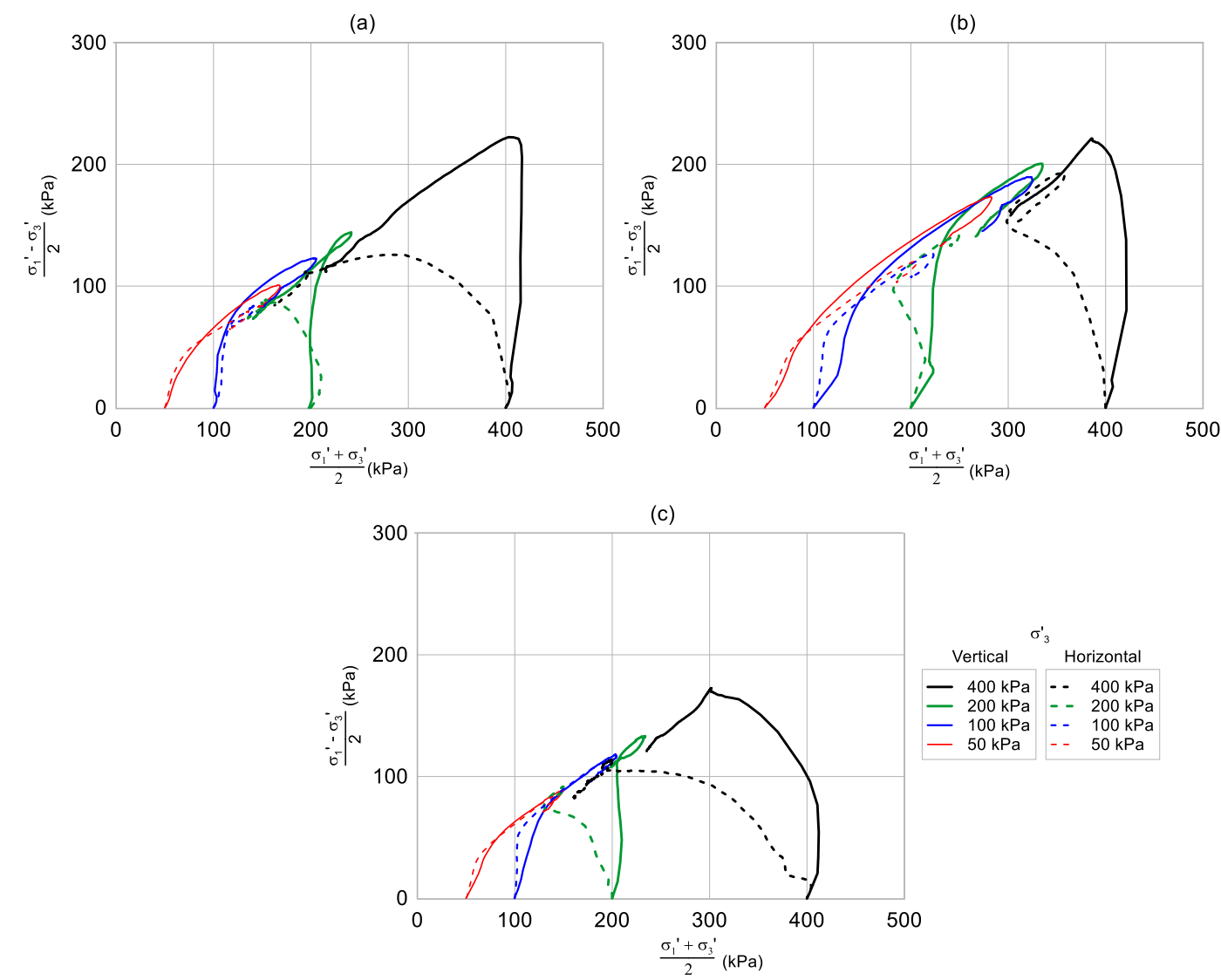

Figura 66 - Trajetória de tensões efetivas: (a) ramo seco; (b) umidade ótima; (c) ramo úmido.

As envoltórias foram determinadas por meio das trajetórias de tensões de tensões efetivas e totais. As Figuras 67, 68 e 69 mostram as envoltórias de resistência ao cisalhamento em termos de tensões efetivas, determinadas por meio das máximas diferenças de tensões principais $\left(\sigma_{1}-\sigma_{3}\right)$. As Figuras 70,71 e 72 mostram as envoltórias de resistência efetivas determinadas por meio das máximas relações entre as tensões efetivas $\left(\sigma_{1}^{\prime}, \sigma_{3}^{\prime}\right)$. Analogamente, as Figuras 73 a 78 mostram as envoltórias de resistência em termos de tensões totais. 


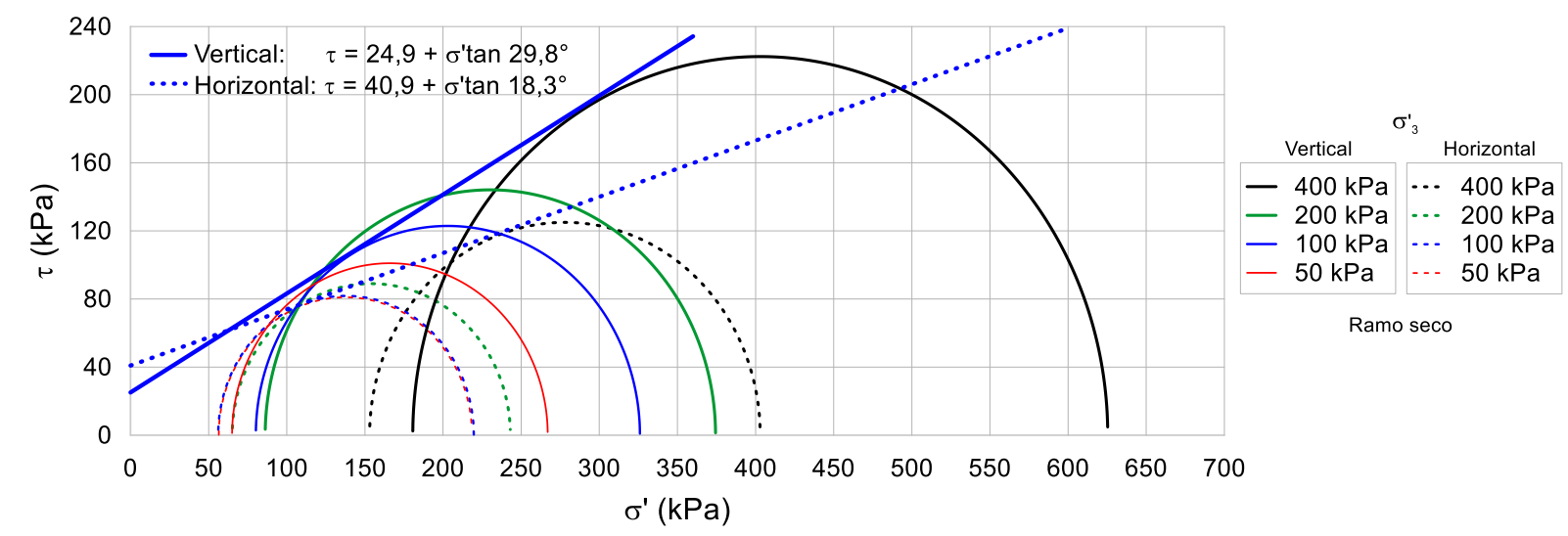

Figura 67 - Envoltória de resistência ao cisalhamento em termos de tensões efetivas com solo compactado no ramo seco para a representação $\left(\sigma_{1}-\sigma_{3}\right)$.

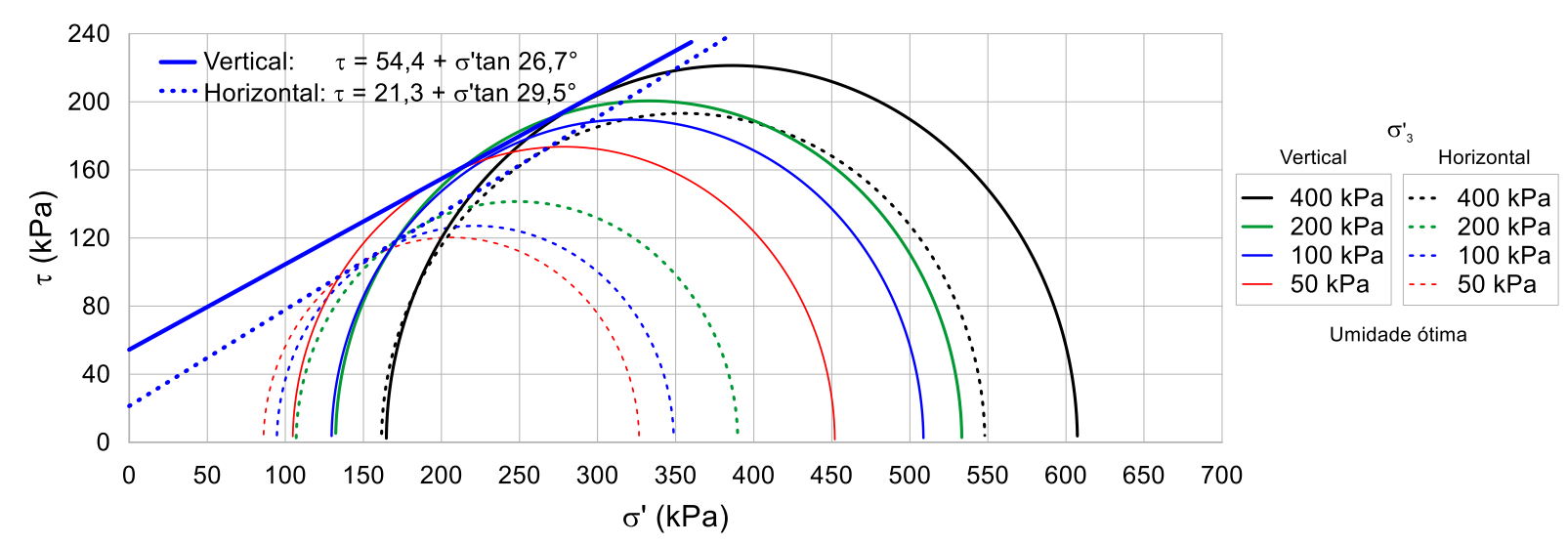

Figura 68 - Envoltória de resistência ao cisalhamento em termos de tensões efetivas com solo compactado na umidade ótima para a representação $\left(\sigma_{1}-\sigma_{3}\right)$.

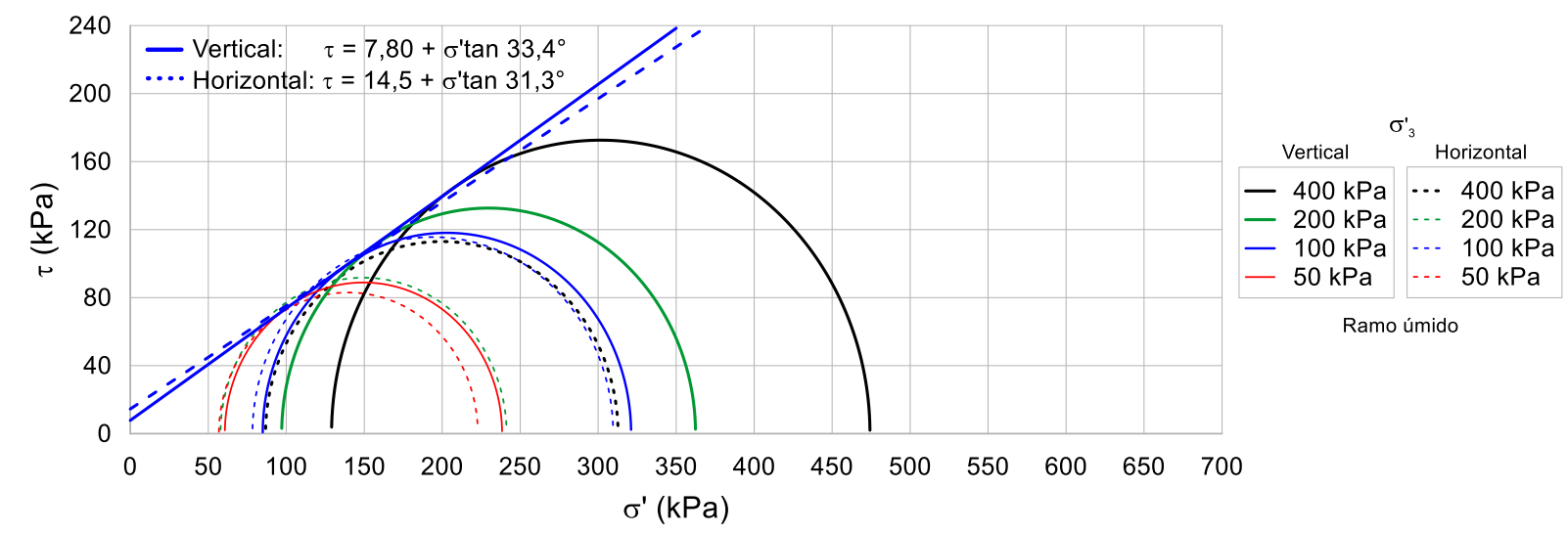

Figura 69 - Envoltória de resistência ao cisalhamento em termos de tensões efetivas com solo compactado no ramo úmido para a representação $\left(\sigma_{1}-\sigma_{3}\right)$. 


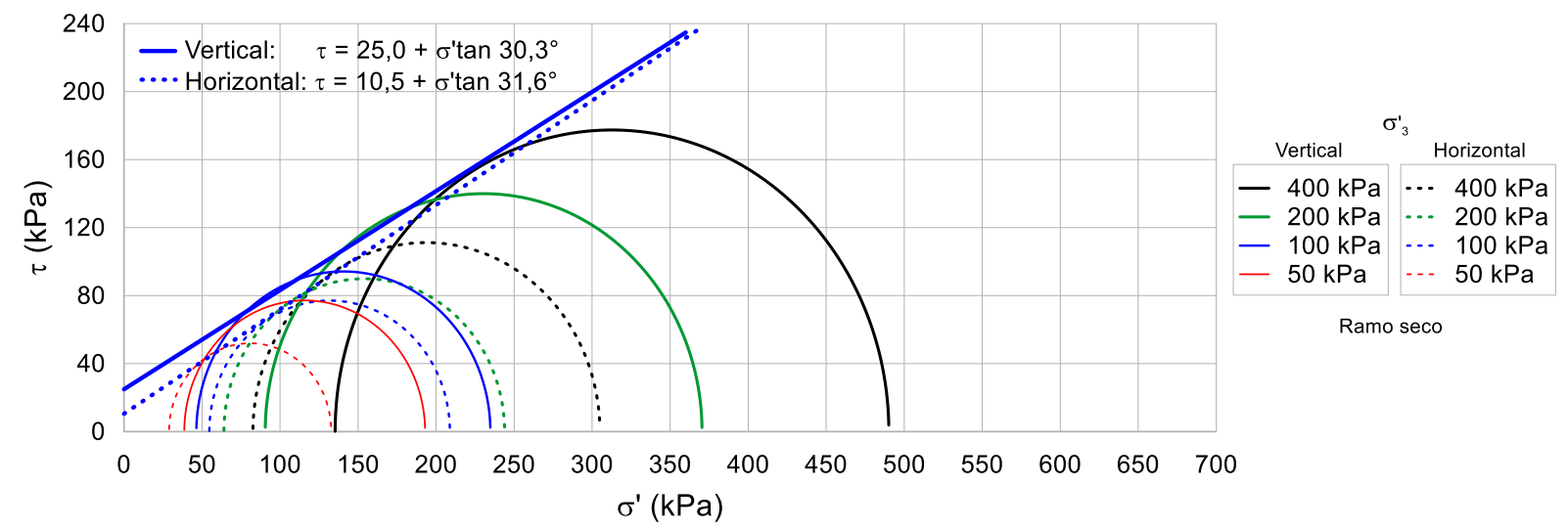

Figura 70 - Envoltória de resistência ao cisalhamento em termos de tensões efetivas com solo compactado no ramo úmido para a representação $\left(\sigma^{\prime}{ }_{1} / \sigma_{3}^{\prime}\right)$.

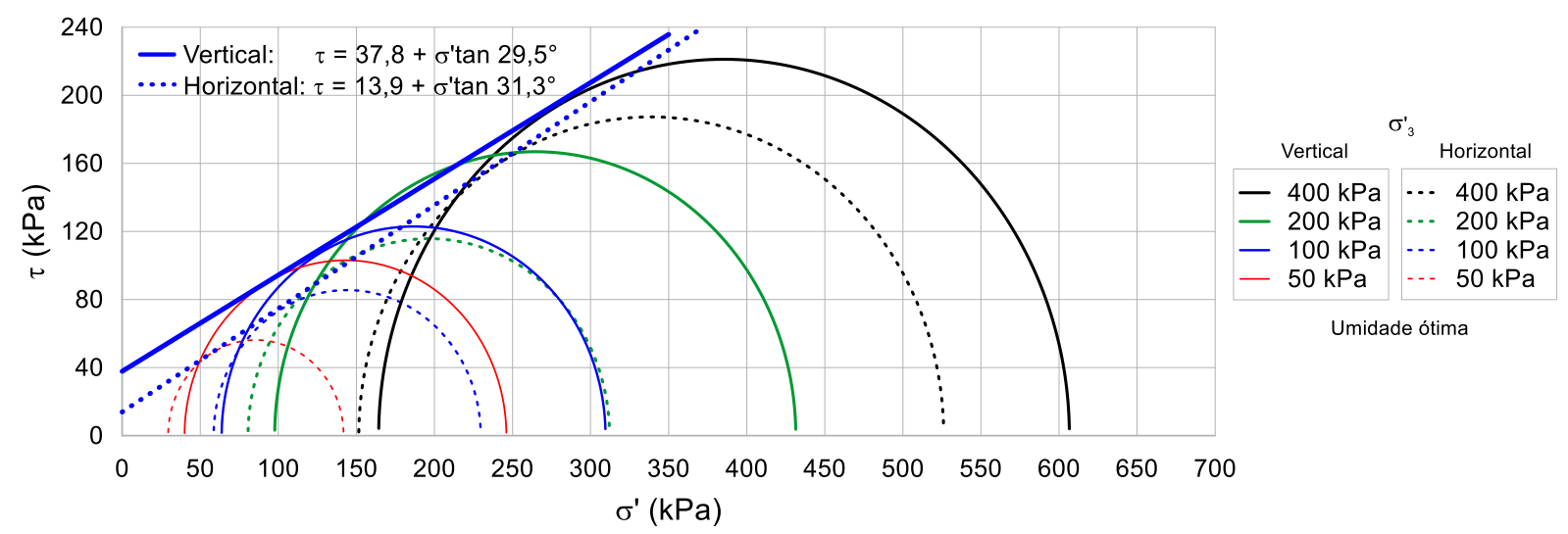

Figura 71 - Envoltória de resistência ao cisalhamento em termos de tensões efetivas com solo compactado na umidade ótima para a representação $\left(\sigma_{1}^{\prime}{ }_{1} / \sigma_{3}^{\prime}\right)$.

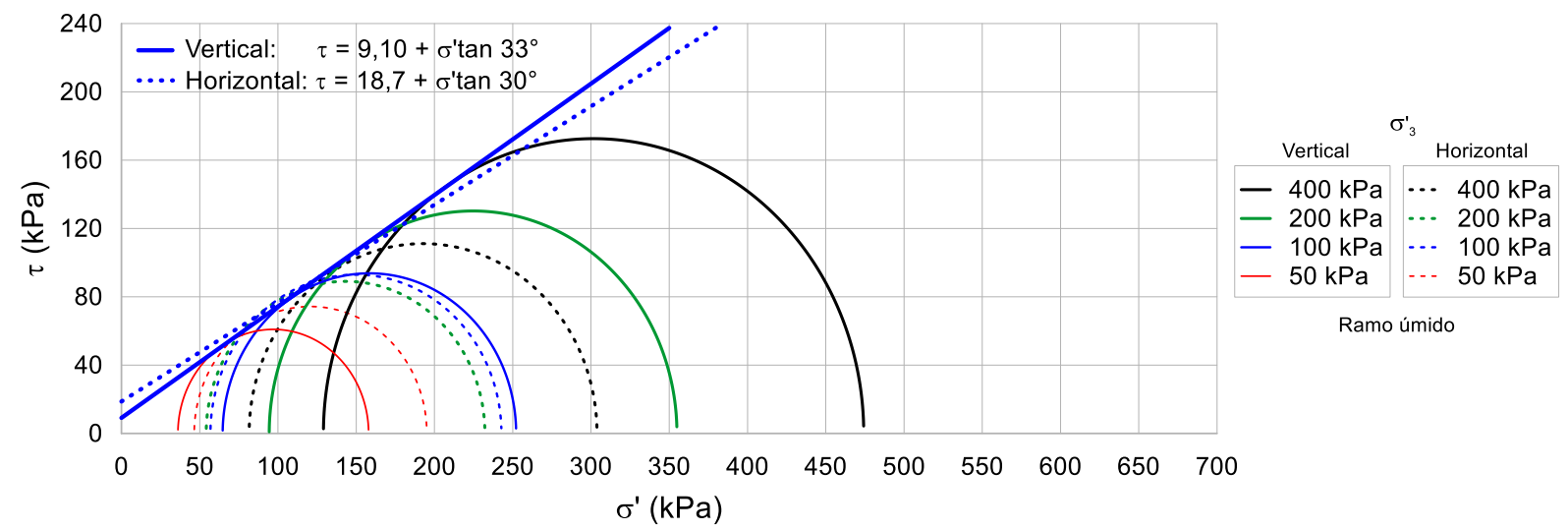

Figura 72 - Envoltória de resistência ao cisalhamento em termos de tensões efetivas com solo compactado no ramo úmido para a representação $\left(\sigma_{1}^{\prime} / \sigma_{3}^{\prime}\right)$. 


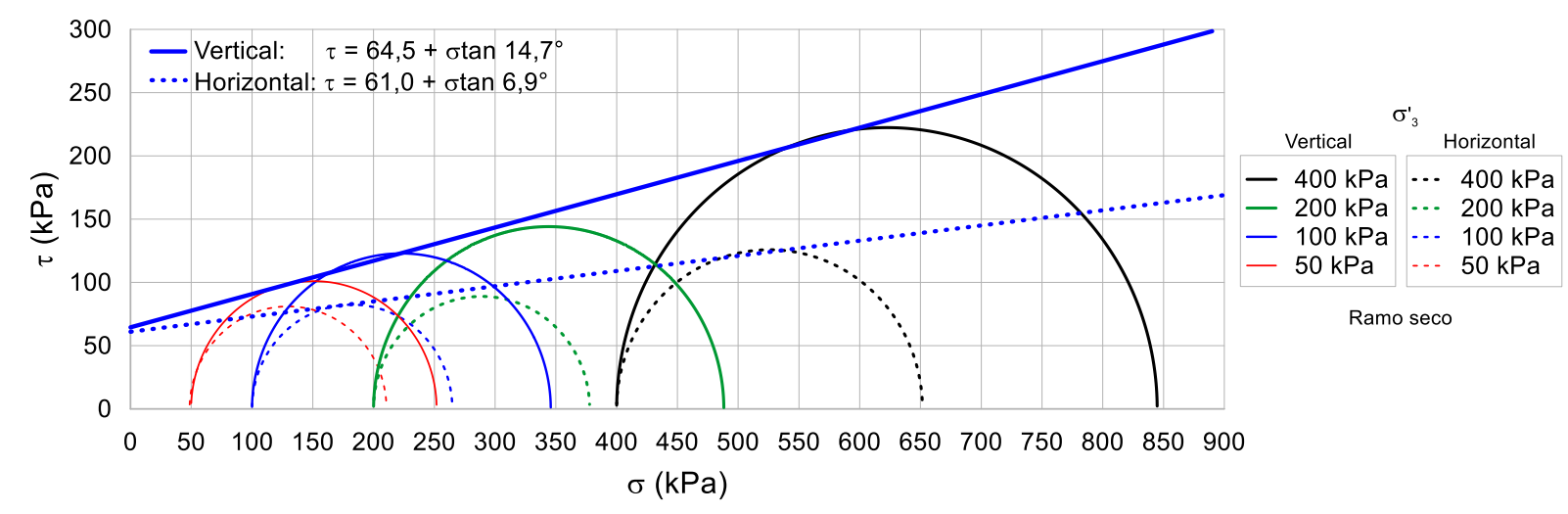

Figura 73 - Envoltória de resistência ao cisalhamento em termos de tensões totais com solo compactado no ramo seco para a representação $\left(\sigma_{1}-\sigma_{3}\right)$.

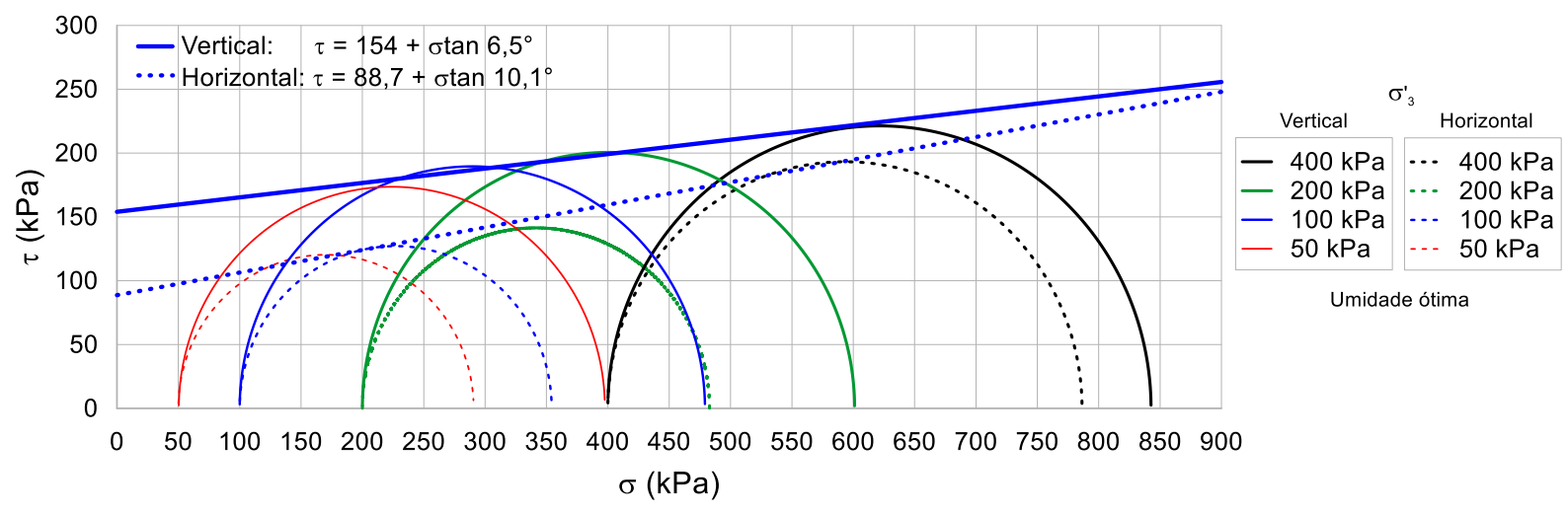

Figura 74 - Envoltória de resistência ao cisalhamento em termos de tensões totais com solo compactado na umidade ótima para a representação $\left(\sigma_{1}-\sigma_{3}\right)$.

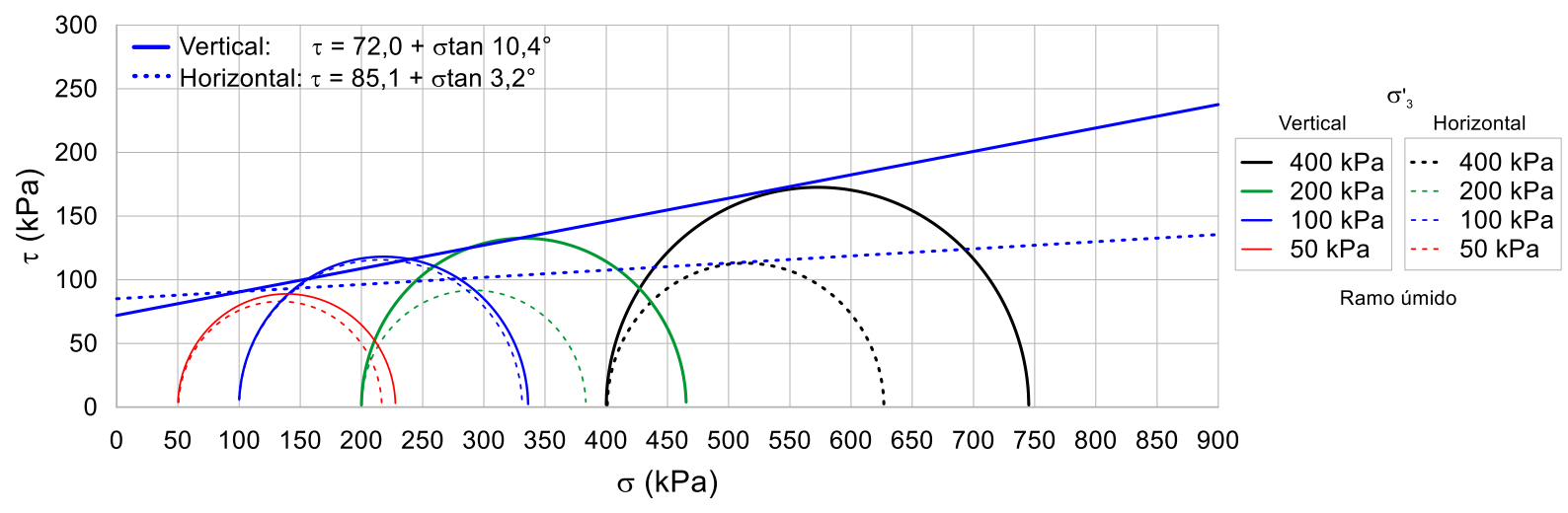

Figura 75 - Envoltória de resistência ao cisalhamento em termos de tensões totais com solo compactado no ramo úmido para a representação $\left(\sigma_{1}-\sigma_{3}\right)$. 


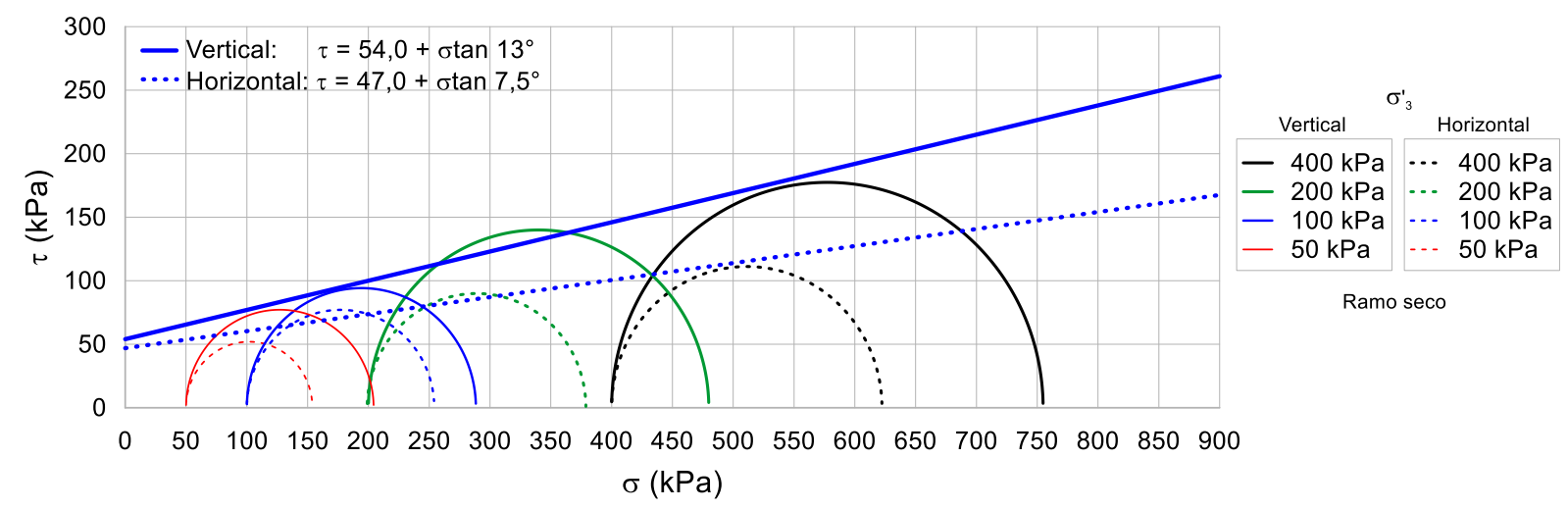

Figura 76 - Envoltória de resistência ao cisalhamento em termos de tensões totais com solo compactado no ramo seco para a representação $\left(\sigma_{1}^{\prime} / \sigma_{3}^{\prime}\right)$.

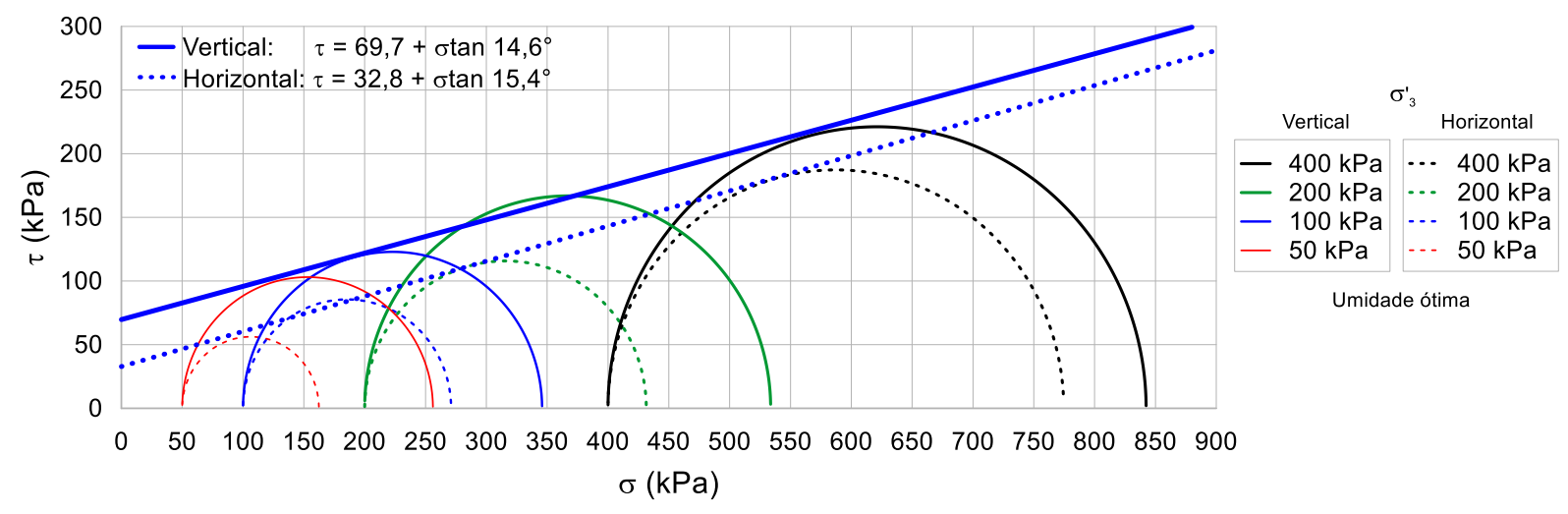

Figura 77 - Envoltória de resistência ao cisalhamento em termos de tensões totais com solo compactado na umidade ótima para a representação $\left(\sigma_{1}^{\prime} / \sigma_{3}^{\prime}\right)$.

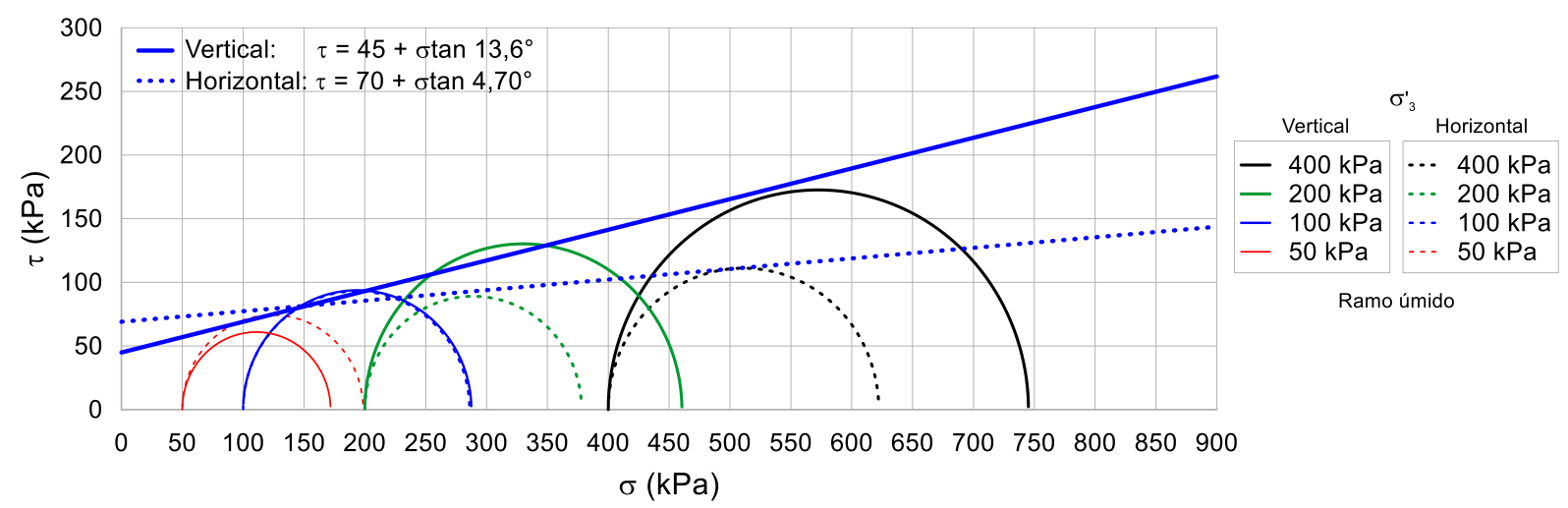

Figura 78 - Envoltória de resistência ao cisalhamento em termos de tensões totais com solo compactado no ramo úmido para a representação $\left(\sigma_{1}^{\prime} / \sigma_{3}^{\prime}\right)$. 
A Figura 79 apresenta as envoltórias de resistência ao cisalhamento em termos de tensões efetivas para as duas direções de talhagem dos corpos de prova correspondentes ao ramo seco, à umidade ótima e ao ramo úmido. Nesta figura torna-se possível a comparação visual dos resultados obtidos através dos dois critérios de interpretação $\left(\sigma_{1}-\sigma_{3}\right.$ e $\left.\sigma_{1}^{\prime} / \sigma_{3}^{\prime}\right)$. Com exceção do ramo seco talhado na direção $\theta=0$, a resistência ao cisalhamento do solo foi pouco afetada pelos critérios de interpretação utilizados.
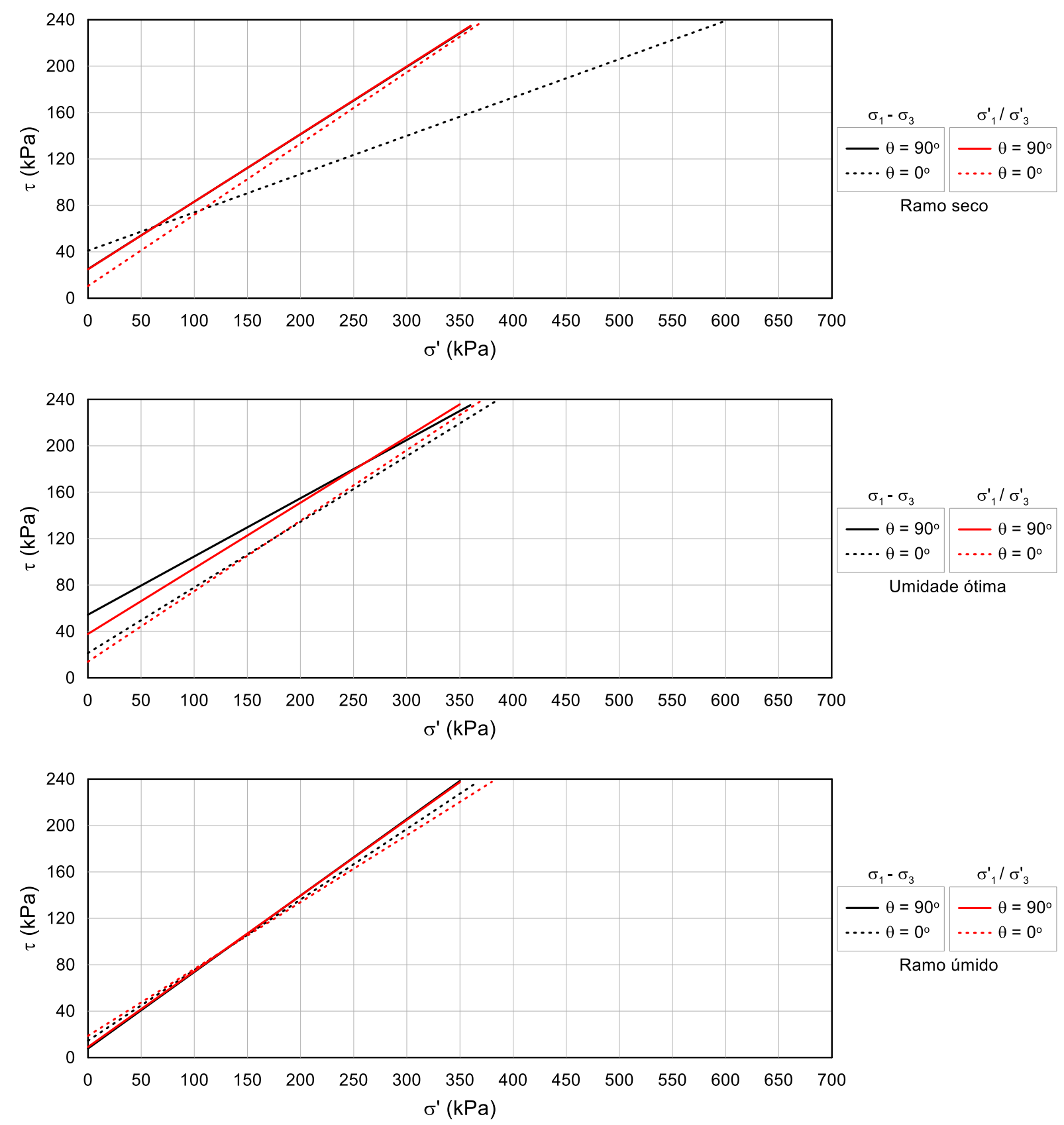

Figura 79 - Envoltória de resistência ao cisalhamento em termos de tensões efetivas. 
Os resultados dos ensaios apontam que o teor de umidade de compactação tem maior influência no intercepto coesivo do que o ângulo de atrito do solo. Oliveira (2004) observou a mesma tendência em solos residuais compactados. Pinto (1971) destaca que este comportamento indica que o intercepto coesivo depende praticamente da massa especifica seca.

Tanto os teores de umidade de compactação como a orientação dos corpos de prova afetaram a resistência ao cisalhamento do solo. Na direção $\theta=0^{\circ}$, o solo compactado no ramo seco apresentou maior resistência ao cisalhamento apenas nas tensões inferiores a $65 \mathrm{kPa}$, quando comparados com a direção $\theta=90^{\circ}$. Na umidade ótima, a resistência ao cisalhamento na direção $\theta=90^{\circ}$ foi maior do que na direção $\theta=0^{\circ}$. Por outro lado, no ramo úmido, a orientação dos corpos de prova não apresentou influência significativa nos resultados dos ensaios. Nota-se que tanto no ramo seco como na umidade ótima a resistência correspondente à direção $\theta=0^{\circ}$ é menor do que a correspondente à direção $\theta=90^{\circ}$.

As envoltórias de resistência ao cisalhamento das amostras compactadas no ramo úmido não sofreram interferências significativas quanto à direção de talhagem dos corpos de prova. Este fato se deve a menor diferença entre as tensões de "pré-adensamento" obtidas por meio dos ensaios de compressão confinada, realizados em corpos de prova talhados na direção vertical e na direção horizontal. Sendo assim, pôde-se associar a menor diferença nas envoltórias de resistência ao cisalhamento à maior capacidade do solo em, a um dado teor de umidade, absorver a energia aplicada e distribuí-la na direção vertical e horizontal da amostra.

Observou-se na seção 5.6 uma maior influência da orientação dos corpos de prova na tensão de "pré-adensamento" nas amostras compactadas no ramo seco, quando comparados aos demais teores de umidade estudados. As maiores diferenças no intercepto coesivo, obtidas no ramo seco, podem estar associadas as diferenças da tensão de "préadensamento" observadas. Acredita-se que, no ramo seco, a menor capacidade do solo de transferir a energia proveniente dos esforços de compactação pode contribuir para a formação de uma estrutura menos resistente na direção horizontal. No ramo úmido, a tensão de "pré-adensamento" praticamente independe da orientação de talhagem das amostras, o que pode estar associados às menores diferenças entre as envoltórias de resistência ao cisalhamento. 


\subsubsection{Resistência não drenada}

O estudo da resistência não drenada dos solos tem aplicação em situações em que o carregamento aplicado gera pressões na água intersticial que não são dissipadas num intervalo de tempo compatível com aplicação dos esforços. Geralmente, em areias, a ruptura se desenvolve de maneira drenada e, em argilas a ruptura ocorre de maneira não drenada, uma vez que ambos os modos de rupturas estão associados à condutividade hidráulica do material. Entretanto, ao avaliar a anisotropia de resistência em areias e argilas, submetidas a ensaios triaxiais, Kurukulasuriya, Oda e Kazama (1999) observaram que o mecanismo que desenvolve as deformações durante a fase de carregamento é similar tanto em areias como em argilas, porém, não são exatamente os mesmos. Sendo assim, optou-se por realizar uma breve análise da influência do teor de umidade de compactação e, da orientação dos corpos de prova na resistência não drenada do solo.

Diversos fatores afetam a resistência não drenada do solo, sendo possível destacar a anisotropia inerente (JAMIOLKOWSKI et al., 1985). Koutsoftas e Ladd (1985) submeteram uma argila marinha a ensaios de compressão triaxial, extensão e cisalhamento simples e, obtiveram bons ajustes utilizando a Equação 23. Por meio desta equação, pode-se afirmar que a resistência não drenada do solo é função da tensão confinante e da tensão de préadensamento. A relação $c_{u} / \sigma_{3}$, dá-se o nome de razão de resistência para condição de solos sobreadensados.

$$
\frac{\mathrm{c}_{\mathrm{u}}}{\sigma_{3}^{\prime}}=S \times \mathrm{OCR}^{m}
$$

Onde: $\mathrm{c}_{\mathrm{u}}=$ resistência não drenada; $\sigma_{3}=$ tensão de confinamento; OCR = razão de sobreadensamento; $S, m=$ coeficientes de ajuste.

Por meio da Equação 23 foi avaliada a relação da resistência não drenada em função da razão de sobreadensamento. Para o cálculo do OCR (over consolidation ratio) foram utilizadas as tensões de pré-adensamento obtidas pelo método Pacheco e Silva (1970) (Tabela 12) e a tensão de confinamento aplicada no corpo de prova. Apresenta-se na Figura 80 a razão de resistência para condição de solos sobreadensados $\left(c_{u} / \sigma_{3}^{\prime}\right)$ em função da razão de sobreadensamento (OCR) e, os ajustes realizados na Equação 23, a partir do qual foi possível expor os coeficientes de ajustes aos resultados da presente pesquisa (Tabela 14). 
Tabela 14 - Parâmetros de ajuste da resistência não drenada do solo

\begin{tabular}{ccccc}
\hline & $\theta^{\circ}$ & $S$ & $m$ & $\mathrm{R}^{2}$ \\
\hline \multirow{2}{*}{ Ramo seco } & 90 & 0,597 & 0,684 & 0,993 \\
& 0 & 0,396 & 0,881 & 0,994 \\
\hline \multirow{2}{*}{ Umidade ótima } & 90 & 0,827 & 0,885 & 0,999 \\
& 0 & 0,690 & 0,854 & 0,995 \\
\hline \multirow{2}{*}{ Ramo úmido } & 90 & 0,515 & 0,677 & 0,995 \\
& 0 & 0,430 & 0,800 & 0,964 \\
\hline
\end{tabular}

A Figura 80 ilustra a variação da resistência não drenada em função da razão de sobreadensamento para os corpos de prova compactados no ramo seco, umidade ótima e ramo úmido, talhados na direção vertical $\left(\theta=90^{\circ}\right)$ e horizontal $\left(\theta=0^{\circ}\right)$, orientados frente ao plano de compactação. Na referida figura, tem-se que a umidade ótima apresentou os maiores valores de resistência não drenada, seguida do ramo seco. Com relação à orientação dos corpos de prova, nota-se que a influência é mais pronunciada na umidade ótima, enquanto que no ramo seco observa-se que a resistência na direção vertical é levemente maior que na direção horizontal. No ramo úmido, as curvas de resistência praticamente se sobrepõem, enfatizando que neste teor de umidade de compactação a influência da anisotropia de resistência é mínima.

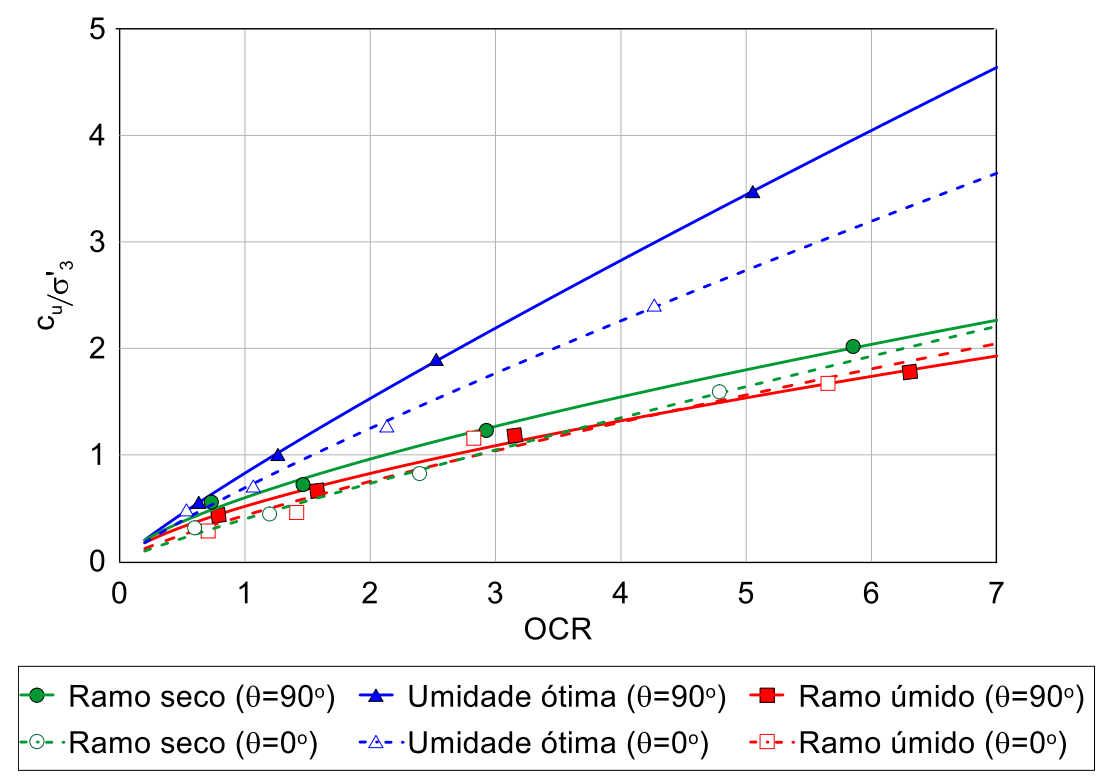

Figura 80 - Variação da resistência não drenada normalizada pela tensão de confinamento.

A influência da orientação dos corpos de prova na resistência não drenada, observada na Figura 80, vai ao encontro das diferenças nas envoltórias de resistência em 
termos de tensões efetivas, ilustradas na Figura 79. Estas diferenças foram mais acentuadas na umidade ótima, enquanto que no ramo úmido a influência da orientação de talhagem dos corpos de prova pouco afetou os parâmetros de resistência do solo. Kurukulasuriya, Oda e Kazama (1999) acreditam que a compatibilidade entre os resultados drenados e não drenados pode significar que a anisotropia da resistência não drenada do solo depende diretamente dos parâmetros $c^{\prime}$ e $\phi^{\prime}$.

\subsection{Ensaios com bender elements}

Os ensaios com bender elements serviram para avaliar o módulo de cisalhamento máximo do solo $\left(G_{m a x}\right)$ em condição não saturada e desconfinada. Estes ensaios foram realizados com corpos de prova talhados nas direções vertical e horizontal, a partir de amostras compactadas com teores de umidade correspondentes ao ramo seco, umidade ótima e ramo úmido. A compactação dos corpos de prova teve como índices físicos alvo aqueles descritos na Tabela 4 (seção 4.5) e as características dos corpos de prova utilizados nesta etapa da pesquisa foram apresentadas na Tabela 10 (seção 5.5).

Os sinais emitidos pelos bender elements foram sempre empilhados 5 vezes, conforme recomendações de Georgetti (2014), esta prática possibilita a redução de possíveis ruídos. A Figura 81 mostra os sinais emitidos com frequência de $10 \mathrm{kHz}$ e os recebidos para os corpos de prova. Além disso, também pode-se observar, por meio da referida figura, que o teor de umidade de compactação tem influência no tempo de percurso da onda $(t)$. O ramo seco, por exemplo, apresenta menor tempo de percurso da onda, o que implica em maiores valores de $G_{\max }$ quando comparadas às demais condições de moldagem dos corpos de prova.

A fim de avaliar a influência das interferências nos ensaios, utilizou-se a relação entre a distância percorrida pelo sinal e o comprimento de onda $\left(L_{t t} / \lambda\right)$ de acordo com sugestões de Sanchez-Salinero, Roesset e Stokoe (1986) e Georgetti (2014). As velocidades obtidas com bender elements podem ser observadas na Figura 82 . Os resultados foram condizentes com aqueles observados por Georgetti (2014) para uma areia argilosa de características e origem bastante similares ao solo utilizado na presente pesquisa. 


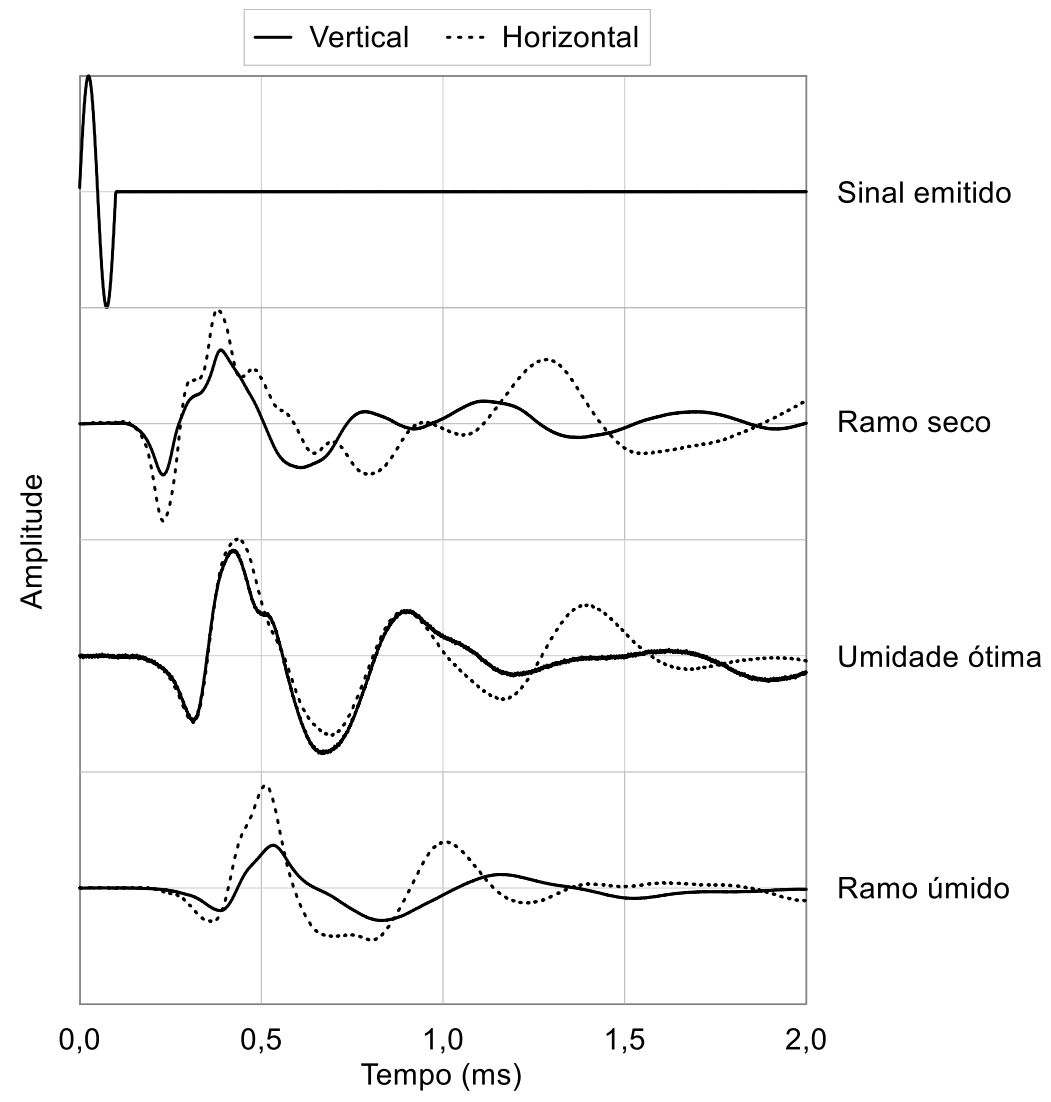

Figura 81 - Resposta para ensaio com bender elements em solos compactados no ramo seco, umidade ótima e ramo úmido para direção vertical e horizontal.

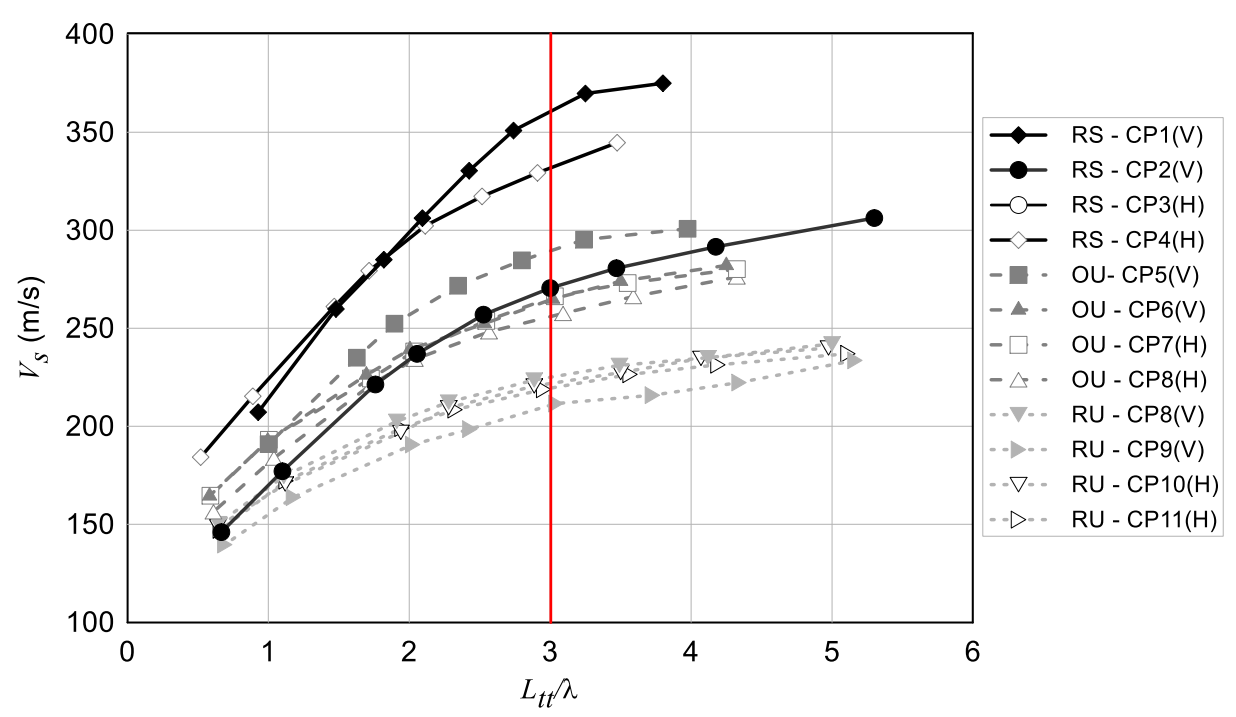

Figura 82 - Velocidade da onda de cisalhamento com bender elements para o solo compactado no ramo seco (RS), umidade ótima $(\mathrm{OU})$ e ramo úmido $(\mathrm{RU})$.

Observa-se que a partir da relação $L_{t} / \lambda$ igual ou maior que 3 , as curvas indicam uma estabilização da velocidade da onda de cisalhamento. Este comportamento é mais 
nítido com o aumento do teor de umidade de compactação, ou seja, no ramo úmido. Sendo assim, adotou-se o critério da relação $L_{t t} / \lambda$ maior ou igual a 3 para determinação da velocidade de cisalhamento a partir dos seus valores médios.

Por meio dos valores de velocidade cisalhante e de massa específica foram calculados os módulos de cisalhamento máximo tanto para os corpos de prova talhados na direção vertical como aqueles talhados na direção horizontal. Os resultados apresentados na Figura 83 sugerem uma diferença no módulo de cisalhamento máximo $\left(G_{\max }\right)$ entre as duas direções analisadas, sendo os maiores valores associados à direção vertical. A tendência de variação do módulo com o teor de umidade para cada direção foi representada por uma reta.

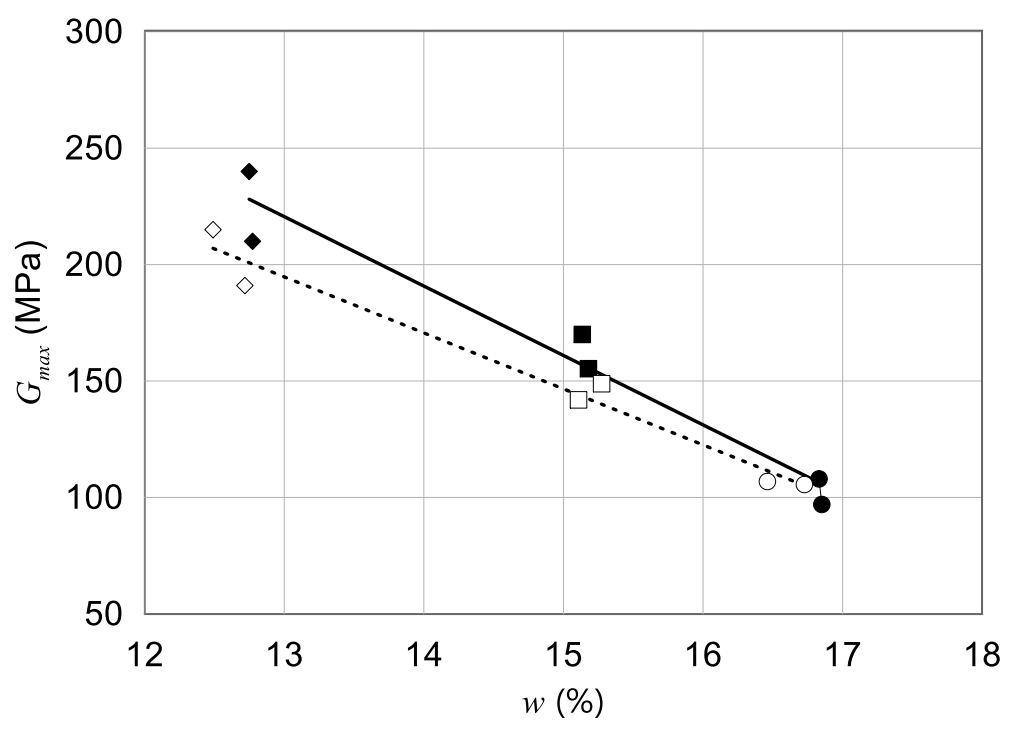

\footnotetext{
- Ramo seco - Vertical

- Umidade ótima - Vertical

- Ramo úmido - Vertical

Ramo seco - Horizontal

Umidade ótima - Horizontal

Ramo úmido - Horizontal
}

Figura 83 - Efeito do teor de umidade no módulo de cisalhamento máximo nos corpos de prova talhados na direção vertical e horizontal.

A maior diferença para as direções analisadas refere-se ao ramo seco. Ao comparar os valores médios entre a direção vertical e horizontal, observou-se que o valor de $G_{\max }$ é $11 \%$ maior na direção vertical. Estes resultados são compatíveis aos apresentados por Ng e Yung (2008) para uma argila siltosa compactada. Sendo assim, a maior diferença observada no ramo seco pode ser atribuída aos maiores valores de sucção nestes corpos de prova, conferindo-os maior rigidez, por mais que a massa específica no ramo seco seja a menor dentre as avaliadas na presente pesquisa. Com isso, o aumento do teor de umidade de compactação contribui para redução da anisotropia inerente na deformabilidade. 



\section{CONCLUSÕES}

Este trabalho teve como principal objetivo a identificação do comportamento anisotrópico de um solo tropical compactado, através de ensaios de laboratório. Ao compactar este solo na energia Proctor Normal foi possível obter sua curva de compactação, e então definir os três teores de umidade considerados nesta pesquisa, correspondentes ao ramo seco, umidade ótima e ramo úmido. A compactação das amostras foi realizada dinamicamente a partir do controle da massa úmida e da altura de cada camada. O aumento do número de camadas não foi capaz de reduzir o efeito do gradiente da massa específica seca ao longo da altura da amostra. Por outro lado, a metodologia desenvolvida para compactação das amostras mostrou-se eficaz na redução desse gradiente e contribuiu para redução da variabilidade dos índices físicos dos corpos de prova talhados. O tingimento das interfaces entre as camadas com azul de metileno contribuiu para a estimativa do gradiente da massa específica seca ao longo da altura das amostras compactadas.

A caracterização mineralógica revelou a presença de minerais típicos de solos de climas tropicais, como: caulinita, gibbsita, quartzo, hematita e goethita. Além disso, a metodologia MCT classificou o solo como laterítico arenoso, LA'. Ao modificar o procedimento de preparação da amostra (sem defloculante e/ou sem dispersão) observouse uma forte influência do procedimento utilizado na preparação das amostras na obtenção das curvas de distribuição granulométrica, a qual pode ser atribuída às agregações provenientes do processo de formação do solo. Além disso, observou-se que a própria dispersão mecânica foi responsável por destruir mais da metade das agregações presentes no solo. Estes ensaios serviram de subsídios para confirmar o caráter laterítico deste solo, típico do interior do Estado de São Paulo.

Os ensaios de porosimetria por intrusão de mercúrio confirmaram a distribuição bimodal dos poros, típicos de materiais compactados. A partir deste, observou-se que o teor de umidade de compactação pouco altera os microporos, por outro lado, o diâmetro e a intensidade dos macroporos são afetados. Os picos do ensaio indicaram tamanho médio dos microporos da ordem de 0,016 $\mu \mathrm{m}$, enquanto que os macroporos apresentaram tamanhos médios de $15 \mu \mathrm{m}, 17 \mu \mathrm{m}$ e $23 \mu \mathrm{m}$ para a umidade ótima, ramo seco e ramo úmido, respectivamente. Observou-se no ramo seco um pico com maior intensidade, estando associado a uma quantidade maior de agregados, característico de estruturas do tipo floculada.

Os ensaios de compressão triaxial do tipo consolidado não drenado (CU) foram realizados a fim de obter as envoltórias de resistência ao cisalhamento, em condição 
saturada, para as amostras talhadas na direção vertical e horizontal frente ao plano de compactação. Ao analisar as diferentes formas de representação da curva tensãodeformação, observou-se que não houve diferenças significativas nos parâmetros de resistência, com exceção do ramo seco talhado na direção vertical. Os corpos de prova talhados na direção vertical apresentaram picos para deformações axiais menores que aqueles talhados na direção horizontal. Por meio das maiores pressões da água intersticial, desenvolvidas durante a ruptura dos corpos de prova, pode-se dizer que as estruturas formadas na direção horizontal apresentam-se mais compressíveis, quando comparadas aos dos corpos de prova talhados na direção vertical.

Os corpos de prova compactados tanto no ramo seco como no ramo úmido apresentaram menor resistência na direção horizontal $\left(\theta=0^{\circ}\right)$ do que na direção vertical $\left(\theta=90^{\circ}\right)$. No ramo úmido, a orientação das amostras não provocou diferenças significativas nos parâmetros de resistência do solo. Com exceção do ramo seco, a orientação das amostras tem maior interferência no intercepto coesivo do que no ângulo de atrito. Convém mencionar que a menor resistência na direção horizontal pode interferir no fator de segurança de maciços compactados. A avaliação da resistência não drenada do solo confirmou a influência da tensão de "pré-adensamento" e da tensão de confinamento na resistência de solos sobreadensados.

O ensaio de compressão confinada foi importante para estimar a tensão de "préadensamento" e avaliar a compressibilidade do solo. Por meio deste ensaio, observou-se que as tensões de confinamento utilizadas no ensaio de compressão triaxial estavam abaixo da tensão de "pré-adensamento". Além disso, o ensaio revelou que existe uma maior influência da orientação dos corpos de prova para as tensões menores que $200 \mathrm{kPa}$, embora esta influência diminua com incremento das tensões aplicadas.

A tensão de "pré-adensamento" na direção vertical foi ligeiramente maior do que na direção horizontal e, esta diferença tende a diminuir com o aumento do teor de umidade de compactação. Por sua vez, uma menor diferença da tensão de "pré-adensamento", entre a direção vertical e à direção horizontal, pode indicar uma maior capacidade do solo em absorver parte da energia de compactação aplicada.

O estudo a respeito da influência da direção de talhagem das amostras nas propriedades hidráulicas do solo compactado indicou que o teor de umidade de compactação e a tensão de confinamento contribuem diretamente na anisotropia de condutividade hidráulica. Observou-se que, independente da direção de fluxo, os menores valores de condutividade hidráulica foram obtidos na umidade ótima. $O$ aumento da tensão de confinamento propiciou a redução da condutividade hidráulica em todas as amostras ensaiadas. No entanto, este efeito foi mais pronunciado para tensões confinantes inferiores a $100 \mathrm{kPa}$. Para tensões confinantes mais altas, não foram observadas reduções 
significativas nos valores da condutividade hidráulica. Observou-se no ramo úmido os maiores valores da relação $k_{h} / k_{v}$, sendo da ordem de 7,9. Esta situação pode estar associada à reduzida presença de macroporos e à orientação preferencial das partículas, dispostas paralelamente ao plano de compactação, favorecendo o fluxo nesta direção.

Foi observada nos ensaios de compressão confinada certa convergência nos valores de módulo, quando as amostras foram submetidas a elevados níveis de carregamento. $O$ ensaio de condutividade hidráulica também experimenta certa convergência, visto à redução da relação $k_{h} / k_{v}$ a medida que as amostras foram submetidas a incrementos sucessivos de tensões de confinamento. Este fato mostra que o papel da anisotropia inerente ao processo de compactação é mais pronunciado para níveis reduzidos de tensões aplicadas.

Os ensaios com bender elements indicaram pouca diferença no módulo de cisalhamento máximo entre as duas direções analisadas. Os corpos de prova talhados na direção vertical apresentaram maior rigidez. Independente da direção analisada, a maior rigidez foi observada no ramo seco, que pode estar associada a menor sucção presente neste teor de umidade. Por fim, observou-se uma tendência linear de decréscimo do módulo de cisalhamento máximo em função do aumento da umidade de compactação.

\subsection{Sugestões para trabalhos futuros}

Ao longo desta pesquisa foram observadas algumas interferências no estudo da anisotropia em solos tropicais compactados. A partir dessas interferências estabeleceram-se algumas linhas de pesquisa para futuros trabalhos, a saber:

- O processo de compactação pode interferir significativamente na estrutura de solos compactados. Propõe-se a realização de ensaios laboratoriais a fim de avaliar a anisotropia através da retirada de blocos indeformados de aterros compactados em campo;

- Os ensaios na presente pesquisa foram realizados com amostras compactadas na energia Proctor Normal. Sugere-se a realização de ensaios com diferentes energias e condições de umidade;

- Aplicação da metodologia desenvolvida para compactação dos corpos de prova (Apêndice A), em outros solos e, submetê-los a diferentes energias de compactação; 
- Os ensaios de compressão triaxial foram realizados em amostras consolidadas isotropicamente. No entanto, o processo de consolidação em campo pode se desenvolver através de trajetórias anisotrópicas. Recomenda-se então, o estudo da anisotropia induzida pelo processo de consolidação anisotrópica em solos compactados;

- Com exceção dos ensaios realizados com bender elements, os demais corpos de prova foram submetidos à prévia saturação. Aconselha-se estudar o efeito da sucção na anisotropia inerente ao ensaio de compactação;

- Os ensaios com bender elements permitem explorar a velocidade de propagação da onda de compressão (tipo $P$ ). Deste modo, propõe-se que seja realizada a medida da propagação da onda de compressão, tanto no sentido vertical como no sentido horizontal;

- Os ensaios de compressão triaxial foram realizados em câmaras convencionais, a partir de corpos de prova cilíndricos. Aconselha-se estudar o efeito da anisotropia através de triaxiais verdadeiros (amostras cúbicas), no intuito de compará-los;

- Para reduzir as incertezas nos resultados dos ensaios de compressão triaxial poderiam ser realizados em câmara triaxial do tipo Bishop-Wesley, utilizando transdutores de efeito Hall. Este equipamento permite a utilização de instrumentação interna para medidas diretas no corpo de prova;

- Propõe-se a realização de simulações numéricas, no intuito de avaliar a influência da anisotropia nos parâmetros de resistência no cálculo do fator de segurança em análise estabilidade de taludes de aterros compactados;

- Os ensaios realizados utilizaram solos lateríticos. Outra frente de estudo, seria avaliar a anisotropia em solos saprolíticos compactados;

- A incorporação de análises estatísticas, englobando testes de hipóteses e análises de variância, poderia explicar o efeito das variáveis de compactação nas propriedades hidráulicas e mecânicas. 


\section{REFERÊNCIAS ${ }^{8}$}

ABRAMSON, N.L.W. Slope stability and stabilization methods. New York: John Wiley, 2002.

AGUIAR, L.A. Contribuições para a análise do comportamento mecânico de solos compactados para uso em barragens. 2010. 127p. Dissertação (Mestrado) -

Universidade de Brasília, Brasília, 2010.

AHMED, S.; LOVELLI, C.W.; DIAMOND, S. Pore sizes and strength of compacted clay. Journal of the Geotechnical Engineering Division, v.100, n.GT4, p.407-425, 1974.

ALBUQUERQUE, P. J. R.; MIGUEL, M.G.; SAUEIA, F.N.; HAJNAL, V.H.; CARVALHO, D. Avaliação de um solo laterítico coluvionar de Campinas/SP, por diferentes procedimentos de determinação de índices físicos. In: CONGRESSO ARGENTINO DE MECÂNICA DOS SOLOS E ENGENHARIA GEOTÉCNICA,18., 2006, San Juan. Anales... [S.I.:s.n.], 2006.

AMERICAN SOCIETY FOR TESTING AND MATERIALS. ASTM D5084: Standard test methods for measurement of hydraulic conductivity of saturated porous materials using a flexible wall permeameter. West Conshohocken, 2010.

ASTM D4767: Standard Test Method for Consolidated Undrained Triaxial Compression Test for Cohesive Soils. West Conshohocken, 2011a. DOI: 10.1520/D4767$11 \mathrm{a}$.

ASTM D2487: Standard practice for classification of soils for engineering purposes

(Unified Soil Classification System). West Conshohocken, 2011b. DOI: 10.1520/D2487-11b.

ASTM D3282: Standard Practice for Classification of Soils and Soil-Aggregate Mixtures for Highway Construction Purposes. West Conshohocken, 2015. D3282 - 15.

ASTM E11: Standard test method for Woven Wire Test Sieve Cloth and Test Sieves1. West Conshohocken, 2015. E11 - 15.

AQUINO FILHO, G.C. Compactação de solos com energias, aproximadamente, iguais e diferentes procedimentos. 1995. 91p. Dissertação (Mestrado) - Escola de Engenharia de São Carlos, Universidade de São Paulo, São Carlos, 1995.

AQUINO, F. R.; GUIMARÃES, R.C.; AGUIAR, L.A.; MIRANDA, C.O.P.; CABRAL, M.P.; CAMAPUM DE CARVALHO. J. Influência dos Métodos de Compactação e Preparação de

\footnotetext{
${ }^{8}$ De acordo com a Associação Brasileira de Normas Técnicas. NBR 6023
} 
Amostras no Comportamento da Curva de Compactação de Solos Tropicais. In:

CONGRESSO BRASILEIRO DE MECÂNICA DOS SOLOS E ENGENHARIA GEOTÉCNICA, 14, 2008. Búzios. Anais... São Paulo: ABMS, 2008.

ARAÚJO, A. Algumas considerações sobre o ensaio de compactação com energia de 585 quilos joule por metro cúbico. 1996. 71p. Dissertação (Mestrado) - Escola de Engenharia de São Carlos, Universidade de São Paulo, São Carlos, 1996.

ARULNATHAN, R.; BOULANGER, R.W.; RIEMER, M.F. Analysis of bender element tests. ASTM Geotechnical Testing Journal, v.21, n.2, p.120-131, 1998.

ASSIS, A.P.; HERNANDEZ, H.M.; COLMANETTI, J.P. Curso de barragens: publicação G.AP-AA006/02. Brasília: Departamento de Engenharia Civil e Ambiental, Universidade de Brasília, 2006. Apostila.

ASSOCIAÇÃO BRASILEIRA DE NORMAS TÉCNICAS. NBR 7183: Determinação do limite e relação de contração de solos. Rio de Janeiro, 1983.

NBR 6508: Grãos de solos que passam na peneira de 4,8 mm - determinação da massa específica. Rio de Janeiro, 1984a.

NBR 7181: Solo - análise granulométrica. Rio de Janeiro, 1984b.

NBR 6459: Solo - determinação do limite de liquidez. Rio de Janeiro, 1984c.

NBR 7180: Solo - determinação do limite de plasticidade. Rio de Janeiro, 1984d.

. NBR 7182: Solo - ensaio de compactação. Rio de Janeiro, 1986.

NBR 10838: Determinação da massa específica aparente de amostras indeformadas, com emprego da balança hidrostática. Rio de Janeiro, 1988.

NBR 12007: Ensaio de adensamento unidimensional. Rio de Janeiro, 1990.

NBR 6502: Rochas e solos. Rio de Janeiro, 1995.

ATKINSON, J.H. Non-linear soil stiffness in routine design. Geotechnique, v.50, n.5, p.487-508, 2000.

BARATA, F.E. Algumas considerações críticas sobre lateritas e materiais lateríticos necessidade de terminologia brasileira adequada. In: SIMPÓSIO BRASILEIRO DE SOLOS 
TROPICAIS EM ENGENHARIA, 1981, Rio de Janeiro. Anais... Rio de Janeiro: COPPE/UFRJ, 1981. v.1, p.308-323.

BARATA, F.E. Crítica os métodos laboratoriais dinâmicos de compactação dos solos. In: I Simpósio sobre pesquisas rodoviárias, 1965, Rio de Janeiro. Anais... Rio de Janeiro: IPR, 1965.

BARATA, F.E. Propriedades mecânicas dos solos: uma introdução ao projeto de fundações. Rio de Janeiro: LTC, 1984.

BARROS, J.M.C. Comparação entre a resistência ao cisalhamento de dois solos lateríticos e dois solos saprolíticos compactados do estado de São Paulo. 1985. Dissertação (Mestrado) - Escola Politécnica, Universidade de São Paulo, São Paulo, 1985.

BARROS, J.M.C.; HACHICH, W. Fundações sujeitas a esforços dinâmicos. In: HACHICH, W. et al. Fundações: teoria e prática. 2.ed. São Paulo: PINI, 1998. Cap.10, p.409-442.

BARROS, J.M.C. Módulo de cisalhamento dinâmico de solos tropicais. 1997. 437p. Tese (Doutorado) - Escola Politécnica, Universidade de São Paulo, São Paulo, 1997.

BARROS, J.M.C.; GIACHETI, H.L.; MARTINS, M.C.R. Dynamic properties of some Brazilian lateritic soils. In: PANAMERICAN CONFERENCE ON SOIL MECHANICS AND FOUNDATION ENGINEERING, 9., 1991, Vinã del Mar. Proceedings... Chile: Sociedad Chilena de Geotecnia, 1991. v.1, p.15-17.

BELLOTTI, R.; JAMIOLKOWSKI, M.; PRESTI, D. L.; O'NEILL, D. Anisotropy of small strain stiffness in Ticino sand. Geotechnique, v.46, n.1, p.115-131, 1996.

BENSON, C.H.; DANIEL, D.E. Influence of clods on the hydraulic conductivity of compacted clay. Journal of Geotechnical Engineering, v.116, n.8, p.1231-1248, 1990.

BENSON, C.H.; TRAST, J.M. Hydraulic conductivity of thirteen compacted clays. Clays and Clay Minerals, v.43, n.6, p.669-681, 1995.

BISHOP, A.W; HENKEL, D.J. The measurement of soil properties in the triaxial test. London: Edward Arnold, 1962

BHASIN, R.N. Pore size distribution of compacted soils after critical region drying. Alexandria: National Technical Information Service, 1975. Monograph.

BORGES, C.R. Estudo microestrutural do comportamento hidromecânico do solo de Brasília-DF, Distrito Federal. 2014. 112p. Tese (Doutorado) - Universidade de Brasília, Brasília, 2014. 
BOYNTON, S.S.; DANIEL, D.E. Hydraulic conductivity tests on compacted clay. Journal of Geotechnical Engineering, v.111, n.4, p.465-478, 1985.

BROMHEAD, E. The stability of slopes. New York: Taylor \& Francis Group, 2006

BRIAUD, J.L. Geotechnical engineering: unsaturated and saturated soils. New York: John Wiley, 2013.

BRIGNOLI, E.G.M.; GOTTI, M.; STOKOE, K.H. Measurement of shear waves in laboratory specimens by means of piezoelectric transducers. Geotechnical Testing Journal, v.19, n.4, p.384-397, 1996.

BRINDLEY, G.W.; BROWN, G. Crystal structures of clay minerals and their $\mathbf{X}$ ray identification. Londres: Mineralogical Society, 1980.

CABRAL, B.P. Verificação da anisotropia em solos do subleito da região metropolitana de Fortaleza pertencente à formação barreiras. 2005. 126f. Dissertação (Mestrado) - Universidade Federal do Ceará, Fortaleza, 2005.

CAMAPUM DE CARVALHO, J.; MIEUSSENS, C.; CARVALHO, J.Q. Problèmes de reconstitution des eprouvettes de sol em laboratoire - Proposition d'une métode, 1985. Bull. Liaison Lab. P. et Ch.,135, pp. 77-83.

CAMAPUM DE CARVALHO, J; CRISPEL, J.J.; MEUSSENS, C.; NARDONE, A. La Recosntituion dês éprovettes em laboratoire: théorie et pratique opératoire. Paris: Laboratorie Central des Ponts et Chaussées, 1987. (Rapport de Recherche LPC № 145).

CAMAPUM DE CARVALHO. J.: GUIMARÃES, R. C.; CARDOSO, F.B.F.; PEREIRA, J. H.F. Proposta de uma metodologia para ensaios de sedimentação. In: REUNIÃO ANUAL DE PAVIMENTAÇÃO, 30., 1996, Salvador. Anais... Rio de Janeiro: ABP, 1996. p.520-531.

CAMAPUM DE CARVALHO, J.; MARINHO, F.A.M., OLIVEIRA, O.M., GITIRANA, G. DE F.N. Contribuição ao entendimento do comportamento dos solos não saturados. In: CONGRESSO BRASILEIRO DE MECÂNICA DOS SOLOS E ENGENHARIA GEOTÉCNICA, 16., 2012, Porto de Galinhas. Anais... São Paulo: ABMS, 2012.

CAMAPUM DE CARVALHO, J; BARBOSA, M.C; MENDONÇA, R.M.G; FARIAS, W.M; CARDOSO, F.B.C. Propriedades químicas, mineralógicas e estruturais de solos naturais e compactados. In: Camapum de Carvalho et al., (Ed.). Solos não saturados no contexto geotécnico. São Paulo: ABMS, 2015. P.39-74.

CAPUTO, H.P. Mecânica dos solos e suas aplicações. Rio de Janeiro: LTC, 1988. v.1. 
CARDOSO, F.B.F. Propriedades e comportamento mecânico de solos do Planalto Central brasileiro. Tese de Doutorado, Programa de Pós-Graduação em Geotecnia, Universidade de Brasília, 407 p, 2002.

CARDOSO, R.; ALONSO, E.E.; NEVES, E.M. A Constitutive model for compacted expansive and bonded marls. Géotechnique, v.63, n.13, p.1116-1130, 2013.

CASAGRANDE, A. The Determination of the pre-consolidation load and its practical significance. In: INTERNATIONAL CONFERENCE ON SOIL MECHANICS AND FOUNDATION ENGINEERING, 1936, Cambridge. Proceedings... Cambridge: Harvard University Graduate School of Engineering, 1936. p.60-64.

CASAGRANDE, A.; CARRILLO, N. Shear failure of anisotropic materials. Journal of the Boston Society for Civil Engineers, v.31, p.122-135, 1944.

CHAN, C.-M. Bender element test in soil specimens: identifying the shear wave arrival time. Eletronic Journal of Geotechnical Engineering, v.15, p.263-1276, 2010.

CHIOSSI, N.J. Geologia de engenharia. 3.ed. São Paulo: Oficina de Textos, 2013.

CRAIG, R.F. Craig's soil mechanics. New York: CRC Press, 2004.

CRISPIM, F.A. Influência de variáveis de compactação na estrutura dos solos: caracterizações geotécnicas, química, mineralógica e microestrutural. 2010. 125p. Tese (Doutorado) - Universidade Federal de Viçosa, Viçosa, 2010.

CRUZ, P.T. 100 barragens brasileiras: casos históricos, materiais de construção, projeto. São Paulo, Oficina de Textos, 1996.

CRUZ, P. T. Características de resistência ao cisalhamento de solos residuais compactados. 1963. Tese (Doutorado) - Escola Politécnica, Universidade de São Paulo, São Paulo, 1963.

CRUZ, P. T. Peculiarities of tropical lateritic and saprolitic soils used as construction materials, selection, control and acceptance criteria-Dams. In: PECULIARITIES FO GEOTECHNICAL BEHAVIOR OF TROPICAL LATERITIC AND SAPROLITIC SOILS PROGRESS REPORT (1982-1985). Committee on Tropical Soils of the ISSMFE. São Paulo. Theme 4. Proceedings... Topic 4.1, p. 275-327, 1985.

CRUZ, P.T.; FERREIRA, R.C. Aterros compactados. In: Cintra, J.C.; ALBIERO, J.H. (Ed.). Solos do interior de São Paulo. São Paulo: ABMS, 1993. p.277-313. 
CRUZ, P.T. Shear strength of compacted residual soils near optimum conditions. In: PANAMERICAN CONFERENCE ON SOIL MECHANICS AND GEOTECHNICAL ENGINEERING, 1999, Foz do Iguaçu. Proceedings... [S.I.:s.n.], 1999. v.1, p.379-385.

DA FONSECA, A.V.; RIOS, S.; AMARAL, M.F. Structural anisotropy by static compaction. Engineering Geology, v.154, p.89-97, 2013.

DANIEL, D.E.; BENSON, C.H. Water content-density criteria for compacted soil liners. Journal of Geotechnical Engineering, v.116, n.12, p.1811-1830, 1990.

DARCY, H. Les Fontaines Publiques de la Ville de Dijon: Exposition et Application des Principes à Suivre et des Formules à Employer dans les Questions de Distribution d'Eau. Paris: Dalmont, 1856. 647 p.

DELAGE, P.; LEFEBVRE, G. Study of the structure of a sensitive Champlain clay and of its evolution during consolidation. Canadian Geotechnical Journal, v. 21, n. 1, p. 21-35, 1984.

DELAGE, P. et al. Microstructure of a compacted silt. Canadian Geotechinical Journal, v.33, p.150-158, 1996.

DEPARTAMENTO NACIONAL DE INFRA-ESTRUTURA DE TRANSPORTE. DNER-ME 256: Solos compactados em equipamento miniatura - Determinação da perda de massa por imersão, Rio de Janeiro, RJ, 1994a, 14p.

-ME 258: Solos compactados em equipamento miniatura - Mini-MCV, Rio de Janeiro, $\overline{R J}, 1994 b, 6 p$.

DUNCAN, J.M.; SEED, H.B. Anisotropy and stress reorientation in clay. Journal of the Soil Mechanics and Foundations Division, v.92, n.5, p.21-50, 1966.

DYVIK, R.; MADSHUS, C. Lab measurements of Gmax using bender element. In: ADVANCES IN THE ART OF TESTING SOILS UNDER CYCLIC CONDITIONS, 1985, Detroit. Proceedings... New York: ASCE, 1985. p.186-196.

FABBRI, G.T.P. Caracterização da fração fina de solos tropicais através da adsorção de azul de metileno. 1994. 101p. Tese (Doutorado) - Escola de Engenharia de São Carlos, Universidade de São Paulo, São Carlos, 1994.

FARIAS, W.M; CAMAPUM DE CARVALHO, J.; DA SILVA, G.F.; CAMPOS, I.C.O.; SANTOS NETO, P.M. Influência da compactação nos micro e mesoporos nanoestruturados e na área superficial específica de um solo laterítico. In: SIMPÓSIO BRASILEIRO DE SOLOS NÃO SATURADOS, 7., 2011, Pirenópolis. Anais... São Paulo: ABMS, 2011. v.1, p.169-175. 
FUTAI, M. M. Estudo teórico-experimental do comportamento de solos tropicais nãosaturados: aplicaçao a um caso de voçorocamento. 2002. 559p. Tese (Doutorado) Universidade Federal do Rio de Janeiro, Rio de Janeiro, 2002.

GARCIA-BENGOCHEA, I.; ALTSCHAEFFL, A.G.; LOVELL, C.W. Pore distribution and permeability of silty clays. Journal of the Geotechnical Engineering Division, v.105, n.7, p.839-856, 1979.

GEORGETTI, G.B. Deformabilidade de um solo laterítico não saturado. 2014. 123p. Tese (Doutorado) - Escola de Engenharia de São Carlos, Universidade de São Paulo, São Carlos, 2014.

GEORGETTI, G.B. Resistência de um solo não saturado a partir de ensaios com teor de umidade constante (CW). 2010. 108p. Dissertação (Mestrado) - Escola de Engenharia de São Carlos, Universidade de São Paulo, São Carlos, 2010.

GERSCOVICH, D.M.S. Estabilidade de taludes. São Paulo: Oficina de Textos, 2012.

GIACHETI, H.L. Estudo experimental de parâmetros dinâmicos de alguns solos tropicais do Estado de São Paulo. 1991. 232 p. Tese (Doutorado) - Escola de Engenharia de São Carlos, Universidade de São Paulo, São Carlos, 1991.

GIDIGASU, M.D. Laterite soil engineering. Amsterdam: Elsever Scientific, 1976.

GREENWOOD, N. N.; EARNSHAW, A. Chemistry of the Elements. Pergamon, Oxiford1984.

HAM, T.G.; NAKATA, Y.; ORENSE, R.; HYODO, M. Strength anisotropy of compacted decomposed granite soils. Geotechnical and Geological Engineering, v.30, n.1, p.119127, 2012.

HEAD, K.H. Manual of soil laboratory testing: effective stress tests. $2^{\text {nd }}$ ed. Chichester: John Wiley, 1998. v.3.

HEITOR, A.; INDRARATNA, B.; RUJIKIATKAMJORN, C. Laboratory study of small-strain behavior of a compacted silty sand. Canadian Geotechnical Journal, v.50, n.2, p.179-188, 2013.

HILF, J.W. Compacted fill. FANG, H. (Ed.). Foundation engineering handbook. $2^{\text {nd }} e d$. New York: Chapman \& Hall, 1991. Cap.8.

HOQUE, E.; TATSUOKA, F. Anisotropy in elastic deformation of granular materials. Soils and Foundations, v.38, n.1, p.163-179, 1998. 
JAMIOLKOWSKI, M.; LADD, C.C; GERMAINE, J.T.; LANCELLOTTA, R. New developments in field and laboratory testing of soils: In: XI ICSMFE., 1985, San Francisco. Proceedings..., 1985, p. 57-153.

JIANG, G. L.; TATSUOKA, F.; FLORA, A.; KOSEKI, J. Inherent and stress-state-induced anisotropy in very small strain stiffness of a sandy gravel. Geotechnique, v.47, n.3, p.509$521,1997$.

JUANG, C.H.; HOLTZ, R.D. Fabric, pore size distribution, and permeability of sandy soils. Journal of geotechnical engineering, v. 112, n. 9, p. 855-868, 1986.

KURUKULASURIYA, L.C.; ODA, M.; KAZAMA, H. Anisotropy of undrained shear strength of an over-consolidated soil by triaxial and plane strain tests. Soils and Foundations, v.39, n.1, p.21-29, 1999.

KIM, H. Anisotropic properties of compacted silty clay. 1996. Thesis (PhD.) Ohio University, Ohio, 1996.

KONGSUKPRASERT, L.; SANO, Y.; TATSUOKA, F. Compaction-induced anisotropy in the strength and deformation characteristics of cement-mixed gravelly soils. In: LING, H.I. et al. (Ed.). Soil stress-strain behavior: measurement, modeling and analysis. Berlin: Springer Netherlands, 2007. p.479-490. (Solid Mechanics and its Applications, 146).

KOUTSOFTAS, D.C.; LADD, C.C. Design strengths for an offshore clay. Journal of Geotechnical Engineering, v. 111, n.3, p.337-355, 1985.

KYOKAWA, $\mathrm{H}$. Elastoplastic constitutive model for saturated and unsaturated soils considering the deposited structure and anisotropy. 2010. 158p. Thesis (PhD.), Department of Civil Engineering, Nagoya Instituted of Technology, Japan, 2010.

LADD, R.S. Preparing test specimens using undercompaction. Geotechnical Testing Journal, v.1, n.1, p.39-49, 1978.

LAMBE, T.W. Soil Stabilization. Foundation Engineering, G.A. Leonards (ed.), McGrawHill, New York, 1962.

LAMBE, T.W. The Structure of compacted clay. Journal of the Soil Mechanics and Foundations Division, v.84 p. 682-705, 1958.

LAMBE, T.W.; WHITMAN, R.V. Soil mechanics. New York: John Wiley, 1969.

LEROUEIL, S.; VAUGHAN, P.R. The general and congruent effects of structure in natural soils and weak rocks. Géotechnique, v. 40, n.3, p. 467-488, 1990. 
LI, X.S. Effective stress in unsaturated soil: a microstructural analysis. Géotechnique, v.53, n.2, p.273-277, 2003.

LUKIANTCHUKI, J.A. Influência do teor de bentonita na condutividade hidráulica e na resistência ao cisalhamento de um solo arenoso utilizado como barreira impermeabilizante. 2007. 124p. Dissertação (Mestrado) - Escola de Engenharia de São Carlos, Universidade de São Paulo, São Carlos, 2007.

MARANHA DAS NEVES, E. The Influence of negative pore-water pressures on the strength characteristics of compacted soils. Traduzido por F. Amuchoistegui; D.G.Fredlund. Lisboa: LNEC, 1971. (Memória n 386).

MASCARENHA, M.M.A. Influência da microestrutura no comportamento hidromecânico de uma argila siltosa não saturada incluindo pequenas deformações. 2008. 158p. Tese (Doutorado) - Universidade de Brasília, Brasília, 2008.

MAŠíN, D. Double structure hydromechanical coupling formalism and a model for unsaturated expansive clays. Engineering Geology, v.165, p.73-88, 2013.

MELLO, V.F.B. Desafios no desenvolvimento de uma engenharia de solos autócne enquadradas em princípios universais. In: CONGRESSO BRASILEIRO DE MECÂNICA DOS SOLOS E ENGENHARIA DE FUNDAÇÕES, 7., 1982, Olinda. Anais... São Paulo: ABMS, 1982. v.8, p.45-136.

MELLO, V.F.B. Reflections on design decisions of practical significance to embankment dams. Geotechnique, v.27, n.3, p.279-356, 1977.

MELO, V.F.; WYPYCH, F. Caulinita e haloisita. Melo, V.V.E. \& Alleoni, L.R. (eds), Química e mineralogia do solo, Parte I, SBCS, Viçosa, v. 1, pp. 427 - 504, 2009.

MICHAELS, A.S.; LIN, C.S. Permeability of kaolinite. Industrial \& Engineering Chemistry, v.46, n.6, p.1239-1246, 1954.

MITCHELL, J.K; SOGA, K. Fundamentals of soil behavior. $3^{\text {th }}$ ed. Hoboken: John Wiley, 2005.

MITCHELL, J.K.; HOOPER, D.R.; CAMPANELLA, R.G. Permeability of compacted clay. Journal of Soil Mechanics \& Foundations Division, v.92, n.SM5, Proc Paper 490, 1965.

MIKASA, M.; TAKADA, N.; OHSHIMA, A. In Situ strength anisotropy of clay by direct shear test. In: ASIAN REGIONAL CONFERENCE ON SMFE, 8., 1987, Kioto. Proceedings... [S.I.:S.n.]. 
MOORE, D.M.; REYNOLDS JR., R.C. X-ray diffraction and the Identification and analysis of clays minerals. New York: Oxford University Press, 1989.

MUKHERJEE, S. The Science of clays: applications in industry, engineering, and environment. Berlin: Springer Science \& Business Media, 2013.

NAKASE, A.; KAMEI, T. Undrained shear strength anisotropy of normally consolidated cohesive soils. Soils and Foundations, v.23, n.1, p.91-101, 1983.

NG, C.W.W.; YUNG, S.Y. Determination of the anisotropic shear stiffness of an unsaturated decomposed soil. Géotechnique, v.58, n.1, p.23-35, 2008.

NOGAMI, J.S.; VILLIBOR, D.F. Pavimentação de baixo custo com solos lateríticos. São Paulo: Villibor, 1995.

ODA, M. Inherent and induced anisotropy in plasticity theory of granular soils. Mechanics of Materials, v.16, n.1, p.35-45, 1993.

OLIVEIRA, O.M. Estudo sobre a resistência ao cisalhamento de um solo residual compactado não saturado. 2004. 330p. Tese (Doutorado) - Escola Politécnica, Universidade de São Paulo, São Paulo, 2004.

OSINUBI, K.J.; NWAIWU, C.M.O. Compacted lateritic soils as hydraulic barriers in waste containment systems. In: Proc. 4th International Congress on Environmental Geotechnics. Rio de Janeiro Proceedings... Brazil, Ashgate San Diego. 2002. p. 225-230.

Design of compacted lateritic soil liners and covers. Journal of geotechnical and geoenvironmental engineering, v. 132, n. 2, p. 203-213, 2006.

Hydraulic conductivity of compacted lateritic soil. Journal of geotechnical and geoenvironmental engineering, v. 131, p. 1034-1041, 2005.

OTÁLVARO, I.F. Comportamento hidromecânico de um solo tropical compactado. 2013. Tese (Doutorado) - Departamento de Engenharia Civil, Universidade de Brasília, Brasília, 2013.

OTÁLVARO, I.F.; CORDÃO NETO, M.P.; CAICEDO, B. Compressibility and microstructure of compacted laterites. Transportation Geotechnics, v. 5, p. 20-34, 2015.

OLSON, R.E.; DANIEL, D.E. Measurement of the hydraulic conductivity of fine-grained soils. In: ZIMMIE, T.F.; RIGGS, C.O. (Ed.). Permeability and groundwater contaminant transport. West Conshohocken: ASTM, 1981. p.18-64. (ASTM STP, v.746). 
PACHECO SILVA, F. Uma nova construção gráfica para a determinação da pressão de préadensamento de uma amostra de solo. In: CONGRESSO BRASILEIRO DE MECÂNICA DOS SOLOS E ENGENHARIA DE FUNDAÇÕES, 4., 1970, Guanabara. Anais... São Paulo: ABMS, 1970. p.219-224.

PAIVA, C.G.E. Estudo experimental de parâmetros elásticos de solo argiloso adensado unidirecionalmente. 1996. Dissertação (Mestrado) - Escola de Engenharia de São Carlos, Universidade de São Paulo, São Carlos, 1996.

PEJON, O.J. Mapeamento geotécnico regional da folha de Piracicaba-SP (escala 1:100.000): estudo de aspectos metodológicos, de caracterização e de apresentação de atributos. 1992. 2v. Tese (Doutorado) - Escola de Engenharia de São Carlos, Universidade de São Paulo, São Carlos, 1992.

PERSONS, B.S. Laterite: genesis, location, use. New York: Plenum Press, 1970.

PINTO, C.S. Curso básico de mecânica dos solos em 16 aulas. São Paulo: Oficina de Textos, 2006.

PINTO, C.S. Sobre as especificações e controle de compactação das barragens de terra. In: SEMINÁRIO NACIONAL DE GRANDES BARRAGENS, 7., 1971, Rio de Janeiro.

Anais... Rio de Janeiro: [s.n.], 1971. v.2.

QUEIROZ, A.C.G. Estudo do comportamento microestrutural de solos tropicais compactados. 2015. 108p. Tese (Doutorado) - Universidade de Brasília, Brasília, 2015.

RAIJ, B. V. A capacidade de troca de cátions das frações orgânica e mineral em solos. Bragantia, 28 (único), 85-112, 1969.

REIS, A.M.S. Comportamento hidro-mecânico de um solo compactado com diferente teor em água e mesmo índice de vazios. 2010. 110p. Dissertação (Mestrado) - Instituto Superior Técnico, Lisboa, 2010.

RICO RODRIGUEZ, A.; DEL CASTILLO, H. Consideraciones sobre compactación de suelos en obras de infraestructura de transporte.

Mexico: Instituto Mexicano del Transporte, 1992. (Documento Tecnico, 7).

ROCHA, B.P. Emprego do ensaio SPT sísmico na investigação de solos tropicais.

2013. 116 p. Dissertação (Mestrado) - Escola de Engenharia de São Carlos, Universidade de São Paulo, São Carlos, 2013.

ROMERO, E. Characterisation and thermo hydro-mechanical behaviour of unsaturated boom clay: an experimental study. 1999. 405p. Tese (Doutorado) Universidade Politécnica da Catalunia, Barcelona, 1999. 
ROMERO, E.; SIMMS, P.H. Microstructure investigation in unsaturated soils: a review with special attention to contribution of mercury intrusion porosimetry and environmental scanning electron microscopy. Geotechnical and Geological Engineering, v.26, n.6, p.705-727, 2008.

ROMERO, E.; DELLA VECCHIA, G.; JOMMI, C. An Insight into the water retention properties of compacted clayey soils. Géotechnique, v.61, p.313-328, 2011.

ROWSHANZAMIR, M.A; ASKARI, A.M. An Investigation on the strength anisotropy of compacted clays. Applied Clay Science, v.50, n.4, p.520-524, 2010.

SANCHEZ-SALINERO, I.; ROESSET, J.M.; STOKOE, K.H.II. Analytical studies of body wave propagation and attenuation. Austin: Civil Engineering Department, University of Texas at Austin, 1986. (Report No.GR 86-15).

SANTOS, P.S. Ciência e tecnologia de argilas. 2.ed. São Paulo: Edgard Blücher, 1989.

SHAFIEE, A. Permeability of compacted granule-clay mixtures. Engineering Geology, v.97, p. 199-208, 2008.

SILVA, C.F. Estudo do comportamento hidráulico de mistura solo-bentonita visando alternativa de emprego como sistema de proteção para aterros sanitários. 2015. 114 p. Dissertação (Mestrado) - Escola de Engenharia de São Carlos, Universidade de São Paulo, São Carlos, 2015.

SILVA, M.A.P. O Estudo de parâmetros geotécnicos de solo arenoso com comportamento anisotrópico. 1996. 113p. Dissertação (Mestrado) - Escola de Engenharia de São Carlos, Universidade de São Paulo, São Carlos, 1996.

SIMMS, P.H.; YANFUL, E.K. A Pore-network model for hydromechanical coupling in unsaturated compacted clayey soils. Canadian Geotechnical Journal, v.42, p.499-514, 2005.

SIVAKUGAN, N.; CHAMEAU, J.L.; HOLTZ, R.D. Anisotropy studies on cuboidal shear device. Journal of Geotechnical Engineering, v.119, n.6, p.973-983, 1993.

SKEMPTON, A.W. The Pore-pressure coefficients A and B. Géotechnique, v.4, n.4, p.143147, 1954.

TEIXEIRA, W. Decifrando a terra. 2.ed. São Paulo: Oficina de Textos, 2008. 
TERZAGHI, V.K. The Shearing resistance of saturated soils and the angle between the planes of shear. In: INTERNATIONAL CONFERENCE ON SOIL MECHANICS AND FOUNDATION ENGINEERING, 1936. Proceedings... Cambridge: Harvard University Press, 1936. p.54-56.

UMAR, S. Y.; ELINWA, A. U.; MATAWAL, D. S. Hydraulic Conductivity of Compacted Lateritic Soil Partially Replaced with Metakaolin. Journal of Environment and Earth Science, v. 5, n. 4, p. 53-64, 2015.

VIGGIANI, G.; ATKINSON, J.H. Interpretation of bender element tests. Géotechnique, v.45, n.1, p.149-154, 1995.

VILLIBOR, D.F; NOGAMI, J.S. Pavimentos econômicos: tecnologia do uso dos solos finos lateríticos. São Paulo: Arte \& Ciência, 2009.

WESLEY, L.D. Fundamentals of soil mechanics for sedimentary and residual soils. New York: John Wiley, 2009.

WITT, K.J.; BRAUNS, J. Permeability-anisotropy due to particle shape. Journal of Geotechnical Engineering, v.109, n.9, p.1181-1187, 1983.

ZENG, X.; NI, B. Stress-induced anisotropic $G_{\max }$ of sands and its measurement. Journal of Geotechnical and Geoenvironmental Engineer, v.125, p.741-749, 1999. 



\section{APÊNDICE A: METODOLOGIA PARA CORREÇÃO DO GRADIENTE DE MASSA ESPECÍFICA SECA}

É corriqueiro que na geotecnia seja necessário avaliar o comportamento mecânico e hidráulico frente a variabilidade dos índices físicos de solos compactados. Nesse intuito, pode-se lançar mão de técnicas para moldagem de corpos de prova na tentativa de impor ao solo índices físicos que o torne apto a um determinado fim. Conhecendo o volume e a área do cilindro de moldagem, pode-se calcular a massa úmida necessária para que após a compactação de cada camada se alcance a massa específica seca esperada. Costuma-se, então, dividir a altura total do cilindro pelo número de camadas estipuladas. Com isso, temse que, durante a moldagem, cada camada é compactada com aproximadamente a mesma espessura e massa úmida. Na Figura A1 é apresentado um esquema da disposição das camadas e suas respectivas identificações frente ao um ponto de origem. Estas identificações serão utilizadas a seguir, em uma tentativa de expor as variáveis utilizadas na metodologia proposta.

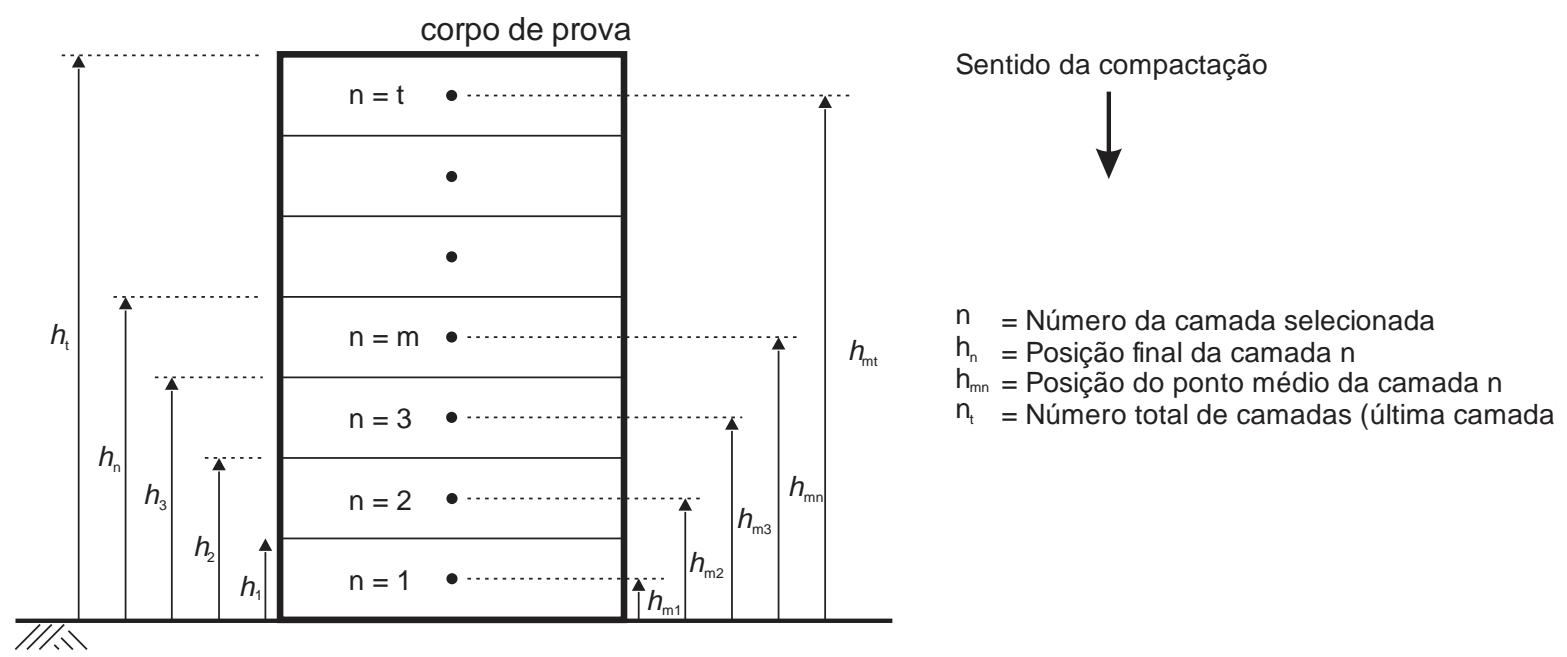

Figura A1 - Esquema utilizado na divisão das camadas do corpo de prova compactado.

Normalmente, acredita-se que ao longo da sobreposição de cada camada a mesma quantidade de energia seja transferida a cada uma delas, de modo que a primeira camada compactada, por exemplo, absorvesse apenas a energia proferida durante a compactação desta. Entretanto, ao deferir golpes sobre a superfície de uma determinada camada ocorre uma transferência parcial desta energia às camadas subjacentes, causando incremento da massa específica seca. Dessa maneira, desenvolve-se uma variabilidade inesperada da 
massa específica ao longo da profundidade do corpo de prova, surgindo um fenômeno denominado de gradiente de massa específica.

Ladd (1978) foi um dos pioneiros na observação deste fenômeno. Utilizando corpos de prova de uma areia mal graduada, preparados por meio de carregamentos cíclicos, Ladd (1978) observou que as primeiras camadas compactadas apresentavam um aumento da massa específica seca. Deste modo, no intuito de solucionar o problema, o referido autor sugeriu que as primeiras camadas fossem compactadas levando em consideração o fator de undercompaction, traduzido para o português como: sub-compactação (Figura A2). A subcompactação diz respeito à correção da massa específica seca por meio da correção da espessura de cada camada durante a compactação. A máxima correção ocorre na primeira camada compactada, de modo que a última camada apresenta sub-compactação próximo ou igual a zero, conforme a Figura A2. A referida figura apresenta a comparação nas tendências da sub-compactação obtida por Ladd (1978) e na presente pesquisa.

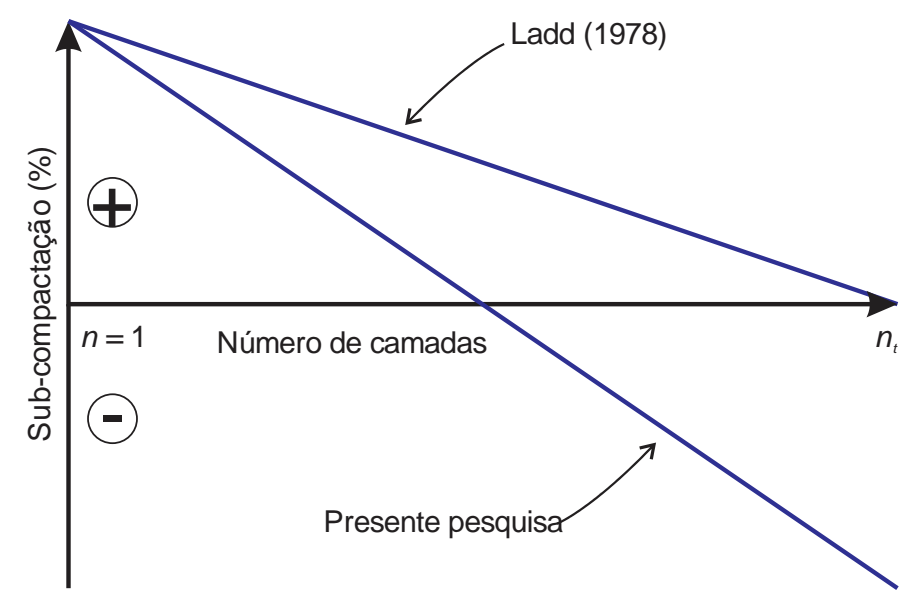

Figura A2 - Comparativo entre as tendências de sub-compactação.

Diferente de Ladd (1978), a presente pesquisa observou a necessidade de se aplicar um fator de sub-compactação menor do que zero nas últimas camadas compactadas. Esta consideração baseia-se no fato de que a presente pesquisa conhece variabilidade da massa específica ao longo do corpo de prova, informação que Ladd (1978) não possuia, portanto, a correção se dá individualmente para cada camada. A fim de validar a eficácia do método, foi compactada uma amostra em que se aplicou um fator de sub-compactação específico para cada camada, sendo possível, então, compará-lo com o método tradicional. Por meio desta análise, foi constatada a redução do gradiente de massa específica seca ao logo da amostra. 
Para corrigir a espessura de cada camada compactada, de modo que o resultado final fossem corpos de prova mais homogêneos e representativos quanto a sua massa específica esperada, lançou-se mão das etapas que serão descritas a seguir:

\section{(I) Determinação do gradiente de massa específica seca}

A primeira etapa consiste em conhecer a variabilidade da massa específica seca ao longo do corpo de prova. Para este fim, pode-se utilizar tanto o método da parafina como o método da medida entre as camadas tingidas com azul de metileno, conforme especificado na seção 4.5. Entretanto, nesta etapa da pesquisa, utilizou-se apenas o método da parafina na determinação da massa específica em 3 pontos distintos ao longo da profundidade da amostra compactada, semelhante ao ilustrado na Figura 33. Para a realização do ajuste linear da massa específica seca ao longo do corpo de prova, utilizaram-se valores das massas específicas secas representativas das três regiões do corpo de prova (A, B e C, ilustrado na Figura 33), denominadas de massa específica seca no ponto médio de cada camada.

Conhecendo a massa específica seca no ponto médio de cada camada $\left(\rho_{\mathrm{dmn}}\right)$ e a posição do ponto médio de cada camada $\left(\mathrm{h}_{\mathrm{mn}}\right)$, realizou-se um ajuste de regressão linear e obteve-se Equação $\mathrm{A} 1$, fornecendo um coeficiente de determinação $\left(R^{2}\right)$ da ordem de 0,976.

$$
\rho_{d m n}=0,011 \times h_{m n}+1,859 \quad R^{2}=0,976
$$

Onde: $\rho_{\mathrm{dmn}}=$ massa específica seca no ponto médio da camada $n\left(\mathrm{~g} / \mathrm{cm}^{3}\right)$; $\mathrm{h}_{\mathrm{mn}}=$ posição do ponto médio da camada $n(\mathrm{~cm})$.

Considerando a Equação A1 como válida para todo o corpo de prova analisado, deve-se corrigir a altura de cada camada compactada.

\section{(II) Correção do gradiente de massa específica seca}

O fator de sub-compactação $\left(S_{n}\right)$ na camada $n$ pode ser obtido por meio da Equação A2. Após este cálculo, determinou-se a posição final corrigida de cada camada $\left(h_{n}{ }^{*}\right)$, conforme Equação A3. 
$S_{n}=\left(1-\frac{\rho_{d m n}}{\frac{1}{n_{t}} \sum_{i=1}^{n_{t}} \rho_{d m n}}\right) \times 100$

$h_{n} *=\left(1+\frac{S_{n}}{100}\right) \times \frac{H}{n_{t}}+h_{n-1} *$

Onde: $S_{n}=$ fator de sub-compactação na camada $n(\%) ; n_{t}=$ número total de camadas; $h_{n}{ }^{*}=$ posição final corrigida da camada $n(\mathrm{~cm}) ; h_{n-1}{ }^{*}=$ posição final corrigida da camada anterior a $n(\mathrm{~cm}) ; H=$ altura total do corpo de prova $(\mathrm{cm})$.

De maneira geral, a metodologia desenvolvida pode ser aplicada a diferentes modalidades de compactação. Entretanto, utilizou-se a compactação da amostra intitulada 7 camadas $^{*}$ a fim de validar a metodologia proposta. Na Tabela A1 são apresentados os dados para correção do gradiente de massa específica seca do caso mencionado. A coluna 2 diz respeito a posição do ponto médio, enquanto a coluna 3 informa os valores da massa específica seca calculado (Equação A1) para cada uma das camadas da amostra identificada como 7 camadas. A coluna 4 retrata o fator de sub-compactação calculado (Equação A2) para cada uma destas camadas. Por fim, a coluna 5 informa as posições finais de cada uma das camadas (Equação A3), utilizadas na compactação da amostra intitulada 7 camadas*. Cabe destacar que a posição final de cada camada foi útil na marcação do gabarito utilizado durante o processo de compactação.

\begin{tabular}{|c|c|c|c|c|}
\hline$(1)$ & (2) & (3) & $(4)$ & (5) \\
\hline $\mathrm{n}$ & $\mathrm{h}_{\mathrm{mn}}(\mathrm{cm})$ & $\rho_{d m n}\left(\mathrm{~g} / \mathrm{cm}^{3}\right)$ & $\mathrm{S}_{\mathrm{n}}(\%)$ & $h_{n}{ }^{*}(\mathrm{~cm})$ \\
\hline 7 & 11,795 & 1,731 & $-3,30$ & 12,716 \\
\hline 6 & 9,995 & 1,751 & $-2,21$ & 10,959 \\
\hline 5 & 8,185 & 1,770 & $-1,11$ & 9,183 \\
\hline 4 & 6,370 & 1,790 & 0,00 & 7,386 \\
\hline 3 & 4,550 & 1,810 & 1,10 & 5,570 \\
\hline 2 & 2,735 & 1,829 & 2,20 & 3,733 \\
\hline 1 & 0,915 & 1,849 & 3,31 & 1,877 \\
\hline
\end{tabular}

Na Figura 55 (seção 5.4) é possível notar o efeito da redução do gradiente de compactação por meio da redução variabilidade da massa específica seca ao longo do 
corpo de prova, quando comparado ao corpo de prova compactado utilizando o método tradicional (7 camadas).

Diversas pesquisas utilizaram o princípio da sub-compactação na prevenção de excessivas densificações nas camadas inferiores. Ng e Yung (2008) compactaram um silte argiloso (ML) em 10 camadas, das quais cada uma delas foi aplicada um fator de subcompactação específico. Na tentativa de corrigir esse fenômeno, os referidos autores compactaram as primeiras camadas com densidades $4 \%$ menores do que a massa específica seca esperada (alvo) e, as últimas 4\% maiores. Estes valores vão ao encontro dos apresentados na Tabela A1 (coluna 4), na qual o fator de sub-compactação $\left(S_{n}\right)$ para correção da primeira camada compactada é da ordem de $3,31 \%$, ou seja, próximo ao adotado por Ng e Yung (2008).

Desse modo, a metodologia utilizada na correção do gradiente de massa específica seca mostrou-se eficaz, servindo de subsídio na compactação de corpos de prova mais homogêneos e representativos das condições esperadas. 